\title{
MAINTENANCE OF THE COAL SAMPLE BANK AND DATABASE
}

Final Technical Report

Reporting Period: 9/29/1993 - 3/30/1999

Principal Investigators: Alan W. Scaroni

Alan Davis

David C. Glick

with contributions by: Patrick G. Hatcher

Gareth D. Mitchell

Daniel Carson

Lei Hou

Report Date: November, 1999

Contract Number DE-AC22-93PC93051

The Pennsylvania State University

Coal and Organic Petrology Laboratories

105 Academic Projects Building

University Park, PA 16802-2300

US/DOE Patent Clearance is not required prior to the publication of this document. 


\title{
DISCLAIMER
}

This report was prepared as an account of work sponsored by an agency of the United States Government. Neither the United States Government nor any agency thereof, nor any of their employees, makes any warranty, express or implied, or assumes any legal liability or responsibility for the accuracy, completeness, or usefulness of any information, apparatus, product, or process disclosed, or represents that its use would not infringe privately owned rights. Reference herein to any specific commercial product, process, or service by trade name, trademark, manufacturer, or otherwise does not necessarily constitute or imply its endorsement, recommendation, or favoring by the United States Government or any agency thereof. The views and opinions of authors expressed herein do not necessarily state or reflect those of the United States Government or any agency thereof.

\begin{abstract}
This project generated and distributed coal samples and accompanying analytical data for use in research by DOE contractors and others. All activities specified under the five-year contract (as revised) and a six-month no-cost extension have been completed.

Eleven DECS samples were collected, processed to a variety of particle sizes, heat-sealed in foil laminate bags under argon, and placed in refrigerated storage. All were analyzed for basic chemical composition, inorganic major and trace element composition including hazardous air pollutant elements, petrographic composition and characteristics, thermoplastic behavior (if applicable), and other properties relevant to research and commercial utilization. Most were also analyzed by NMR, py/gc/ms, and a standardized liquefaction test; trends and relationships observed were evaluated and summarized. Twenty-two DECS samples collected under the previous contract received further processing, and most of these were subjected to organic geochemical and standardized liquefaction tests as well. Selected DECS samples were monitored annually to evaluate the effectiveness of foil laminate bags for preserving samples in long-term storage.
\end{abstract}

In addition to the 33 DECS samples, 23 PSOC samples collected under previous contracts and purged with argon before storage were also maintained and distributed, for a total of 56 samples covered by the contract. During the 5.5 years, 570 samples in 1,586 containers, 2,109 data printouts, and individual data items from 34,208 samples were distributed. All DECS samples are now available for distribution at minus $6 \mathrm{~mm}(-1 / 4 \mathrm{inch})$, minus $0.85 \mathrm{~mm}$ (- $20 \mathrm{mesh}$ U.S.), and minus $0.25 \mathrm{~mm}$ (- 60 mesh U.S.). 


\section{TABLE OF CONTENTS}

DISCLAIMER $\ldots \ldots \ldots \ldots \ldots \ldots \ldots \ldots \ldots \ldots \ldots \ldots \ldots \ldots \ldots \ldots \ldots$

ABSTRACT $\ldots \ldots \ldots \ldots \ldots \ldots \ldots \ldots \ldots \ldots \ldots \ldots \ldots \ldots \ldots \ldots \ldots \ldots$

LIST OF TABLES $\ldots \ldots \ldots \ldots \ldots \ldots \ldots \ldots \ldots \ldots \ldots \ldots \ldots \ldots \ldots \ldots \ldots \ldots$

LIST OF FIGURES $\ldots \ldots \ldots \ldots \ldots \ldots \ldots \ldots \ldots \ldots \ldots \ldots \ldots \ldots$

EXECUTIVE SUMMARY $\ldots \ldots \ldots \ldots \ldots \ldots \ldots \ldots \ldots \ldots \ldots \ldots \ldots \ldots$

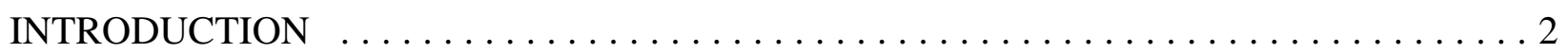

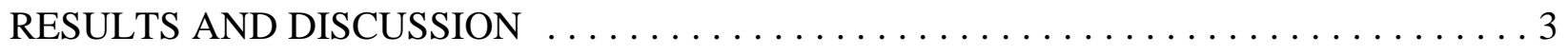

Task 1. The Coal Sample Bank $\ldots \ldots \ldots \ldots \ldots \ldots \ldots \ldots \ldots \ldots \ldots \ldots \ldots$

Task 1A. Initiation of Sample Bank Activities $\ldots \ldots \ldots \ldots \ldots \ldots \ldots \ldots \ldots$

Task 1B. Storage and Inventory of Samples $\ldots \ldots \ldots \ldots \ldots \ldots \ldots \ldots \ldots \ldots$

Refrigerated Storage for all DECS samples $\ldots \ldots \ldots \ldots \ldots \ldots \ldots \ldots$

Computerized Inventory Tracking $\ldots \ldots \ldots \ldots \ldots \ldots \ldots \ldots \ldots \ldots \ldots \ldots \ldots \ldots \ldots \ldots \ldots \ldots$

Task 1C. Monitoring of Sample Condition after Storage $\ldots \ldots \ldots \ldots \ldots \ldots \ldots \ldots \ldots \ldots$

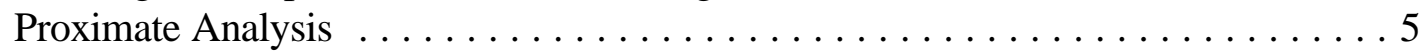

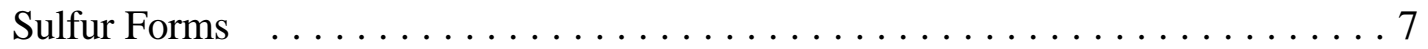

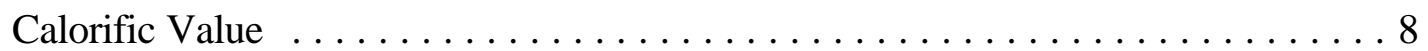

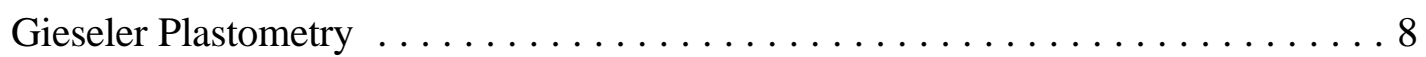

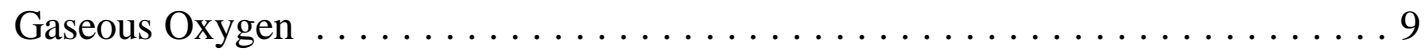

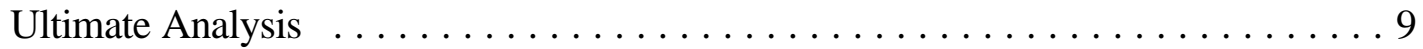

Task 1D. Collection and Processing of Replacement Samples . . . . . . . . . . . . . . 11

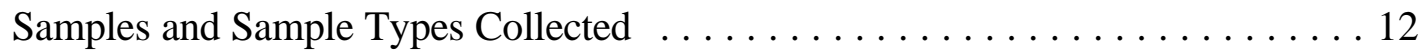

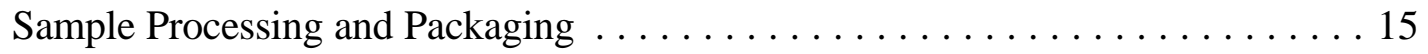

Task 1E. Basic Characterization of Coal Samples $\ldots \ldots \ldots \ldots \ldots \ldots \ldots \ldots \ldots \ldots$

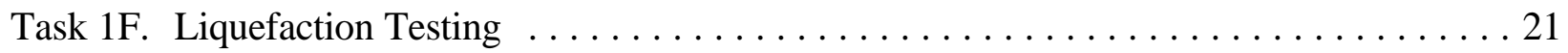

Development of a Standardized Liquefaction Test . . . . . . . . . . . 21

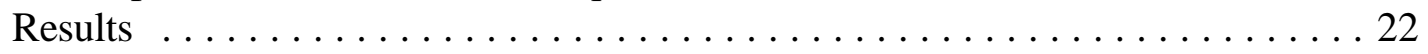

Task 1G. Investigation of Changes in Surface Chemistry During Storage $\ldots \ldots \ldots . \ldots 36$ 
Task 1H. Organic Geochemistry . . . . . . . . . . . . . . . . . . 36

Nuclear Magnetic Resonance: CPMAS, DDMAS, and Bloch Decay . . . . . . . 37

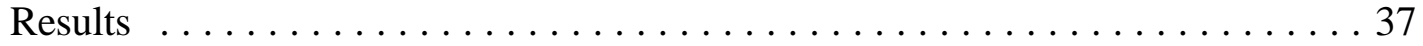

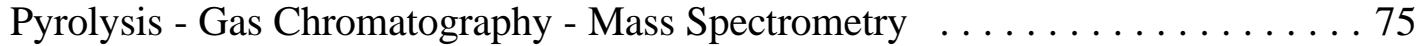

Results ..................................... 75

Task 1I. Distribution of Coal Samples to Users $\ldots \ldots \ldots \ldots \ldots \ldots \ldots \ldots \ldots \ldots \ldots \ldots \ldots$

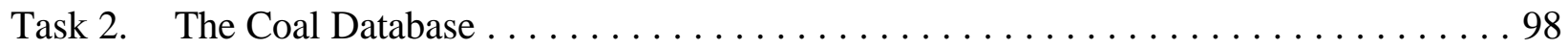

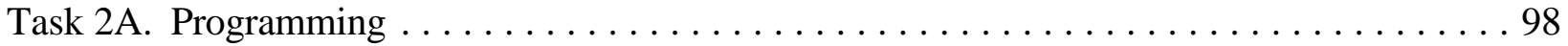

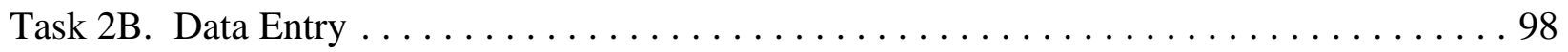

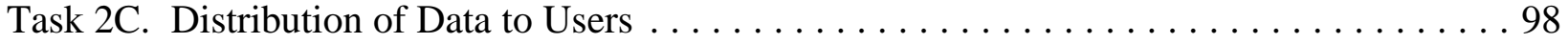

CONCLUSIONS .................................. 100

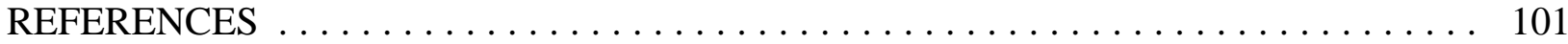

APPENDIX A. Monitoring of DECS Coals to Evaluate Sample Condition after Storage . . 103

APPENDIX B. Method for Standardized Liquefaction Test and Product Workup . . . . 133

APPENDIX C. Agencies Supplied with Coal Samples and/or Data 9/29/93 to 3/30/99 . . . . 140

APPENDIX D. Coal Database Printouts of DECS Samples $\ldots \ldots \ldots \ldots \ldots \ldots \ldots$

APPENDIX E. Coal Sample Bank and Database Brochure $\ldots \ldots \ldots \ldots \ldots \ldots \ldots$ 


\section{LIST OF TABLES}

$\underline{\text { Table }}$

$\underline{\text { Page }}$

1. ASTM repeatability and reproducibility values $\ldots \ldots \ldots \ldots \ldots \ldots \ldots \ldots \ldots \ldots \ldots \ldots$

2. Changes in volatile matter, carbon and oxygen after storage in foil laminate bags $\ldots \ldots 6$

3. Correspondence of Argonne Premium Coal Samples to DECS samples . . . . . . . . . . 14

4. Hazardous Air Pollutant Element Analyses of DECS samples, as ppm dry coal . . . . . 20

5. Conversion of DECS samples in a standardized liquefaction test using tetralin $\ldots \ldots \ldots 23$

6. Conversion of DECS samples in a standardized liquefaction test, comparing results from

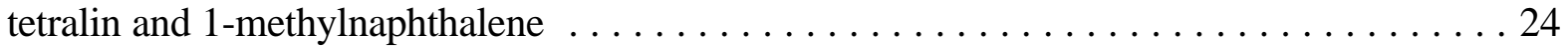

7. Structural parameters of DECS coals determined by CPMAS measurements $\ldots \ldots \ldots 38$

8. Structural Parameters of DECS coals determined by DDMAS measurements . . . . . . . 39

9. Structural parameters determined by $\mathrm{py} / \mathrm{gc} / \mathrm{ms}$ (percent of total gc-amenable products) . . 88

10. Structural parameters determined by $\mathrm{py} / \mathrm{gc} / \mathrm{ms}$ (percent of identified products) $\ldots . \ldots 89$

11. Sample distribution by category of recipient's use $\ldots \ldots \ldots \ldots \ldots \ldots \ldots \ldots \ldots \ldots$

12. Samples and data distributed $9 / 29 / 93$ to $3 / 30 / 99 \ldots \ldots \ldots \ldots \ldots \ldots \ldots \ldots \ldots$

13. Data delivered to users via the world wide web site $\ldots \ldots \ldots \ldots \ldots \ldots$ 


\section{LIST OF FIGURES}

Figure $\quad$ Page

1. Change in sulfate sulfur after storage in foil laminate bags $\ldots \ldots \ldots \ldots \ldots \ldots \ldots$

2. Change in calorific value after storage in foil laminate bags $\ldots \ldots \ldots \ldots \ldots$

3. Change in Gieseler fluid range after storage in foil laminate bags $\ldots \ldots \ldots \ldots \ldots$

4. Change in carbon after storage in foil laminate bags $\ldots \ldots \ldots \ldots \ldots \ldots \ldots \ldots \ldots$

5. Change in oxygen after storage in foil laminate bags $\ldots \ldots \ldots \ldots \ldots \ldots \ldots$

6. Change in calorific value with change in carbon for DECS samples monitored $\ldots \ldots \ldots 11$

7. Apparatus for inert gas purging of samples stored temporarily in 113 liter steel drums . . 13

8. Typical crushing and splitting steps for a DECS sample $\ldots \ldots \ldots \ldots \ldots \ldots \ldots \ldots$

9. Vitrinite reflectance vs. carbon content $\ldots \ldots \ldots \ldots \ldots \ldots \ldots \ldots \ldots \ldots \ldots \ldots \ldots \ldots$

10. Vitrinite reflectance vs. calorific value $\ldots \ldots \ldots \ldots \ldots \ldots \ldots \ldots \ldots \ldots \ldots \ldots \ldots \ldots \ldots$

11. Vitrinite reflectance vs. volatile matter $\ldots \ldots \ldots \ldots \ldots \ldots \ldots \ldots \ldots \ldots$

12. Total liquefaction conversion vs. carbon content, percent of dry ash-free coal $\ldots \ldots \ldots 26$

13. Total liquefaction conversion, percent of dry ash-free coal, vs. vitrinite reflectance . . . . 27

14. Asphaltene products vs. carbon content, percent of dry ash-free coal $\ldots \ldots \ldots \ldots$

15. Asphaltene products, percent of dry ash-free coal, vs. vitrinite reflectance . . . . . . . . 29

16. Preasphaltene products vs. carbon content, percent of dry ash-free coal $\ldots \ldots \ldots 30$

17. Preasphaltene products, percent of dry ash-free coal, vs. vitrinite reflectance $\ldots \ldots \ldots . \ldots 31$

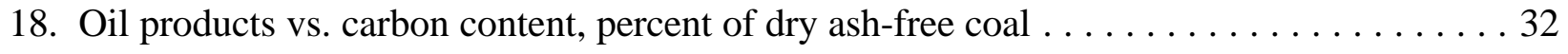

19. Oil products, percent of dry ash-free coal, vs. vitrinite reflectance $\ldots \ldots \ldots \ldots \ldots$

20. Gas products vs. carbon content, percent of dry ash-free coal $\ldots \ldots \ldots \ldots \ldots \ldots$ 


\section{LIST OF FIGURES (continued)}

Figure

$\underline{\text { Page }}$

21. Gas products, percent of dry ash-free coal, vs. vitrinite reflectance $\ldots \ldots \ldots \ldots$

22. CPMAS NMR spectrum of DECS-1, subC Bottom seam, TX . . . . . . . . 40

23. Bloch decay NMR spectrum of DECS-1, subC Bottom seam, TX $\ldots \ldots \ldots \ldots$

24. CPMAS NMR spectrum of DECS-2, hvCb Illinois \#6 seam, IL . . . . . . . . . . 41

25. Bloch decay NMR spectrum of DECS-2, hvCb Illinois \#6 seam, IL . . . . . . . . 41

26. CPMAS NMR spectrum of DECS-8, subC Smith-Roland ("Wyodak") seam, WY . . . . 42

27. Bloch decay NMR spectrum of DECS-8, subC Smith-Roland ("Wyodak”) seam, WY . . 42

28. CPMAS NMR spectrum of DECS-9, subB Dietz seam, MT $\ldots \ldots \ldots \ldots \ldots$

29. Bloch decay NMR spectrum of DECS-9, subB Dietz seam, MT . . . . . . . . 43

30. CPMAS NMR spectrum of DECS-11, ligA Beulah seam, ND . . . . . . . . . 44

31. Bloch decay NMR spectrum of DECS-11, ligA Beulah seam, ND . . . . . . . . . 44

32. CPMAS NMR spectrum of DECS-12, hvAb Pittsburgh seam, PA $\ldots \ldots \ldots \ldots 4$

33. Bloch decay NMR spectrum of DECS-12, hvAb Pittsburgh seam, PA . . . . . . . . 45

34. CPMAS NMR spectrum of DECS-13, mvb Sewell seam, WV . . . . . . . . 46

35. Bloch decay NMR spectrum of DECS-13, mvb Sewell seam, WV . . . . . . . . 46

36. CPMAS NMR spectrum of DECS-17, hvAb Blind Canyon seam, UT . . . . . . . . . 47

37. Bloch decay NMR spectrum of DECS-17, hvAb Blind Canyon seam, UT . . . . . . . . 47

38. CPMAS NMR spectrum of DECS-18, hvBb Kentucky \#9 seam, KY . . . . . . . . . . 48

39. Bloch decay NMR spectrum of DECS-18, hvBb Kentucky \#9 seam, KY . . . . . . . 48

40. CPMAS NMR spectrum of DECS-19, lvb Pocahontas \#3 seam, VA . . . . . . . . . . . . 49 


\section{LIST OF FIGURES (continued)}

Figure $\quad$ Page

41. Bloch decay NMR spectrum of DECS-19, lvb Pocahontas \#3 seam, VA . . . . . . . . . 49

42. CPMAS NMR spectrum of DECS-23, hvAb Pittsburgh seam, PA $\ldots \ldots \ldots \ldots \ldots$

43. Bloch decay NMR spectrum of DECS-23, hvAb Pittsburgh seam, PA . . . . . . . . . 50

44. CPMAS NMR spectrum of DECS-24, hvCb Illinois \#6 seam, IL . . . . . . . . . . 51

45. Bloch decay NMR spectrum of DECS-24, hvCb Illinois \#6 seam, IL . . . . . . . . . . 51

46. CPMAS NMR spectrum of DECS-25, ligA Pust seam, MT $\ldots \ldots \ldots \ldots \ldots \ldots$

47. Bloch decay NMR spectrum of DECS-25, ligA Pust seam, MT $\ldots \ldots \ldots \ldots 2$

48. CPMAS NMR spectrum of DECS-26, subB Wyodak seam, WY $\ldots \ldots \ldots \ldots$

49. Bloch decay NMR spectrum of DECS-26, subB Wyodak seam, WY . . . . . . . 53

50. CPMAS NMR spectrum of DECS-27, subA Deadman seam, WY . . . . . . . . . 54

51. Bloch decay NMR spectrum of DECS-27, subA Deadman seam, WY . . . . . . . . . 54

52. CPMAS NMR spectrum of DECS-28, hvCb Green seam, AZ . . . . . . . . 55

53. Bloch decay NMR spectrum of DECS-28, hvCb Green seam, AZ . . . . . . . . . 55

54. CPMAS NMR spectrum of DECS-29, hvAb Upper Banner seam, VA . . . . . . . . . 56

55. Bloch decay NMR spectrum of DECS-29, hvAb Upper Banner seam, VA . . . . . . . 56

56. CPMAS NMR spectrum of DECS-30, mvb Splash Dam seam, VA . . . . . . . . . 57

57. Bloch decay NMR spectrum of DECS-30, mvb Splash Dam seam, VA . . . . . . . . . 57

58. CPMAS NMR spectrum of DECS-31, hvAb Pond Creek seam, KY . . . . . . . . 58

59. Bloch decay NMR spectrum of DECS-31, hvAb Pond Creek seam, KY . . . . . . . 58

60. CPMAS NMR spectrum of DECS-32, hvAb Stockton-Lewiston seam, WV . . . . . . . 59 


\section{LIST OF FIGURES (continued)}

Figure

$\underline{\text { Page }}$

61. Bloch decay NMR spectrum of DECS-32, hvAb Stockton-Lewiston seam, WV . . . . . 59

62. CPMAS NMR spectrum of DECS-33, hvBb Ohio \#4 seam, $\mathrm{OH} \ldots \ldots \ldots \ldots$

63. Bloch decay NMR spectrum of DECS-33, hvBb Ohio \#4 seam, OH . . . . . . . 60

64. Carbon aromaticity vs. carbon content of dry ash-free coal for 21 DECS samples . . . . 61

65. Carbon aromaticity vs. vitrinite reflectance for 21 DECS samples $\ldots \ldots \ldots \ldots \ldots 2$

66. Aromatic + carbonyl + carboxyl fraction of total carbons vs. carbon content of

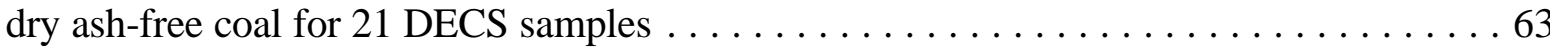

67. Aromatic + carbonyl + carboxyl fraction of total carbons vs. vitrinite reflectance

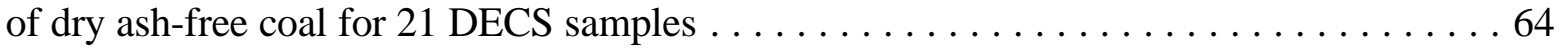

68. Phenolic fraction of total carbons vs. carbon content of dry ash-free coal

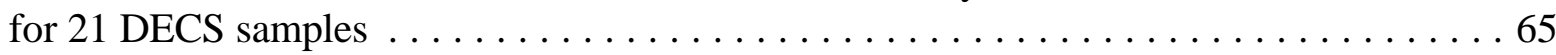

69. Phenolic fraction of total carbons vs. vitrinite reflectance of dry ash-free coal

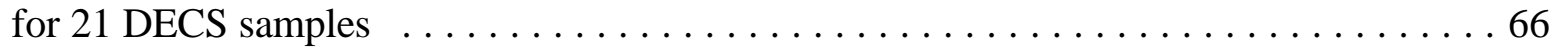

70. Carboxyl + carbonyl fraction of total carbons vs. carbon content of dry

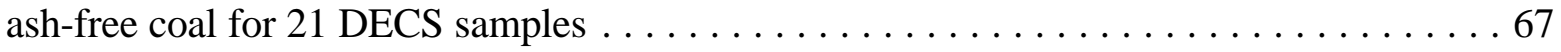

71. Carboxyl + carbonyl fraction of total carbons vs. vitrinite reflectance of dry

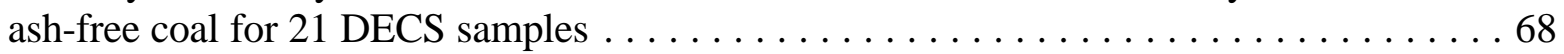

72. Oxygenated aliphatic fraction of total carbons vs. carbon content of dry ash-free coal for 21 DECS samples

73. Oxygenated aliphatic fraction of total carbons vs. vitrinite reflectance of dry

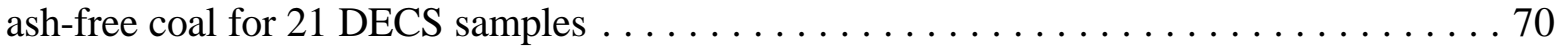

74. Aromatic protonated fraction of total carbons vs. carbon content of dry

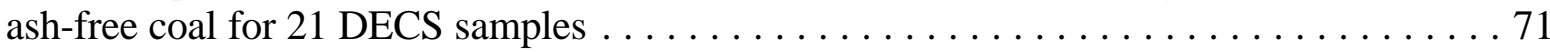

75. Aromatic protonated fraction of total carbons vs. vitrinite reflectance of dry ash-free coal for 21 DECS samples 


\section{LIST OF FIGURES (continued)}

$\underline{\text { Figure }}$

Page

76. Mobile $\mathrm{CH}_{3}+$ quaternary aliphatic fraction of total carbons vs. carbon content of dry

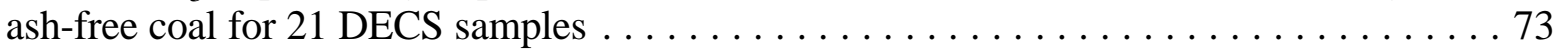

77. Mobile $\mathrm{CH}_{3}+$ quaternary aliphatic fraction of total carbons vs. vitrinite reflectance

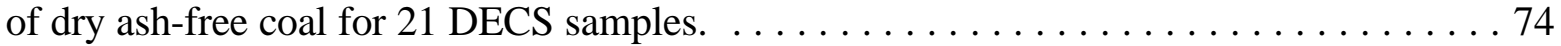

78. Total ion chromatogram of pyrolyzates from DECS-1, subC Bottom seam, TX. . . . . 77

79. Total ion chromatogram of pyrolyzates from DECS-2, hvCb Illinois \#6 seam, IL . . . . 77

80. Total ion chromatogram of pyrolyzates from DECS-8, subC Smith-Roland

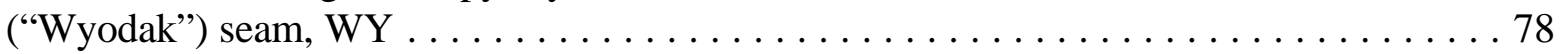

81. Total ion chromatogram of pyrolyzates from DECS-9, subB Dietz seam, MT . . . . . 78

82. Total ion chromatogram of pyrolyzates from DECS-11, ligA Beulah seam, ND . . . . 79

83. Total ion chromatogram of pyrolyzates from DECS-12, hvAb Pittsburgh seam, PA . . . 79

84. Total ion chromatogram of pyrolyzates from DECS-13, mvb Sewell seam, WV . . . . 80

85. Total ion chromatogram of pyrolyzates from DECS-17, hvAb Blind Canyon seam, UT . . 80

86. Total ion chromatogram of pyrolyzates from DECS-18, hvBb Kentucky \#9 seam, KY . . 81

87. Total ion chromatogram of pyrolyzates from DECS-19, lvb Pocahontas \#3 seam, VA . . 81

88. Total ion chromatogram of pyrolyzates from DECS-23, hvAb Pittsburgh seam, PA . . . 82

89. Total ion chromatogram of pyrolyzates from DECS-24, hvCb Illinois \#6 seam, IL . . . 82

90. Total ion chromatogram of pyrolyzates from DECS-25, ligA Pust seam, MT $\ldots \ldots \ldots 8$

91. Total ion chromatogram of pyrolyzates from DECS-26, subB Wyodak seam, WY . . . 83

92. Total ion chromatogram of pyrolyzates from DECS-27, subA Deadman seam, WY . . . 84

93. Total ion chromatogram of pyrolyzates from DECS-28, hvCb Green seam, AZ . . . . . 84 


\section{LIST OF FIGURES (continued)}

Figure $\quad$ Page

94. Total ion chromatogram of pyrolyzates from DECS-29, hvAb U. Banner \#3 seam, VA . . 85

95. Total ion chromatogram of pyrolyzates from DECS-30, mvb Splash Dam seam, VA . . . 85

96. Total ion chromatogram of pyrolyzates from DECS-31, hvAb Pond Creek seam, KY . . 86

97. Total ion chromatogram of pyrolyzates from DECS-32, hvAb Stockton-

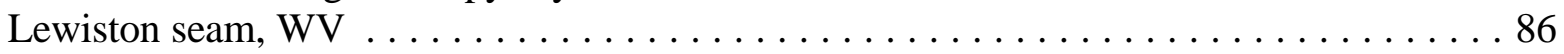

98. Total ion chromatogram of pyrolyzates from DECS-33, hvBb Ohio \#4A seam, OH $\ldots 87$

99. Non-oxygenated aromatic hydrocarbon fraction of identified products vs. carbon

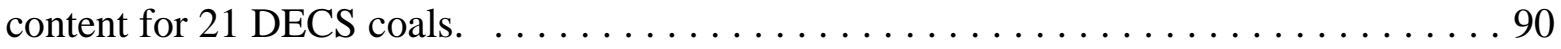

100. Non-oxygenated aromatic hydrocarbon fraction of identified products vs. vitrinite

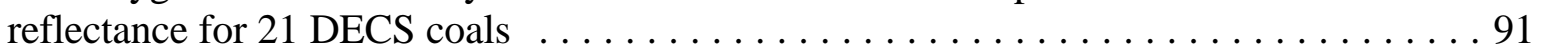

101. n-Alkanes + alkenes fraction of identified products vs. carbon content for

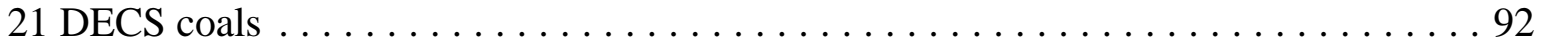

102. n-Alkanes + alkenes fraction of identified products vs. vitrinite reflectance for 21

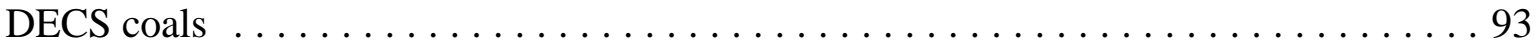

103. Phenolic fraction of identified products vs. carbon content for 21 DECS coals . . . . . 94

104. Phenolic fraction of identified products vs. vitrinite reflectance for 21 DECS coals . . . 95 


\title{
EXECUTIVE SUMMARY
}

\author{
Maintenance of the Coal Sample Bank and Database
}

Final Technical Report 9/28/1993 - 3/30/1999

The mission of the DOE Coal Sample Bank and Database is to provide a variety of wellcharacterized, high-quality coal samples for public and private coal research. Eleven coal samples collected under the current contract and 45 from previous contracts, along with analytical data, are distributed on a continuing basis to DOE contractors and others performing coal research.

Additional analyses of liquefaction behavior and organic geochemical characteristics revealed through $\mathrm{py} / \mathrm{gc} / \mathrm{ms}$ and NMR studies were performed under the contract. The samples are stored to minimize deterioration, and 10 samples were analyzed annually to monitor the effectiveness of the storage methods. Foil laminate bags purged with argon gas and stored under refrigeration were shown to perform well in preserving the properties of the coal samples.

This report reflects the level of effort described in the revised work statement submitted to DOE on September 5, 1996, setting out a reduction in effort following a cut in the level of funding of the project. 


\section{INTRODUCTION}

This five and one-half year project was performed to ensure the availability of wellcharacterized, high-quality coal samples for public and private coal research. It continued support of the DOE Coal Sample Bank and Database at The Pennsylvania State University, an effort which followed projects funded first by the Office of Coal Research, then the Energy Research and Development Administration, and several successive contracts with the Department of Energy. No further funding is planned by DOE.

Eleven coal samples in the DECS- series have been collected, processed, packaged, and extensively analyzed under the contract, and a resulting database is being maintained. These samples and data, as well as 22 DECS samples and 23 PSOC samples collected under previous contracts, were distributed on a ongoing basis to DOE contractors and others performing coal research.

Samples were chosen to maintain a sample bank of 56 coals representing the major U.S. coal fields and a variety of coal ranks and compositions. In addition to standard analyses, liquefaction tests and organic geochemical analyses (NMR, py/gc/ms) have been performed. The DECS samples employ advanced storage techniques (foil laminate bags purged with argon, heatsealed and refrigerated) to minimize deterioration; ten are monitored annually by proximate, sulfur forms, calorific value, and gaseous oxygen analysis to evaluate their condition. In the fourth year, additional monitoring was performed to evaluate the influence of various storage methods. The monitoring program showed that foil laminate bags continue to preserve the samples well. 


\section{RESULTS AND DISCUSSION}

\section{Task 1. The Coal Sample Bank}

\section{Task 1A. Initiation of Sample Bank Activities}

This contract continued support of a previous sample bank and database at Penn State, so activities commenced immediately. Coal samples and data were already located at Penn State; the inventory and procedures for storage, selection, retrieval and distribution were in place and fully functional. Samples and data were available for distribution from the first day of the contract.

\section{Task 1B. Storage and Inventory of Samples}

All samples supported by the contract are stored in containers purged with argon before sealing; container locations are tracked by a computer inventory program. PSOC-series samples are stored in drums or buckets at the Coal Sample Bank building, or in cans in the Coal and Organic Petrology Laboratories. All DECS-series samples are stored in foil laminate bags; the methods by which they are processed and packaged are discussed under Task 1D.

\section{Refrigerated Storage for all DECS samples}

During the previous contract, a 4.25 cubic meter (150 cubic foot) refrigerator had been acquired to store the candidates (DECS-15, -16 and 17) for the special dispersed catalyst liquefaction sample. The refrigerator was also used to store part of the set of $300 \mathrm{~g}$ foil laminate bags from each successive sample DECS-18 through -22 collected later in that contract. As planned, four months after the inception of the subject contract a larger refrigerated storage facility became available. All containers of all DECS samples were moved to this 164 cubic meter (5,780 cubic foot) refrigerated room. All samples collected under the current contract have been stored under refrigeration for their entire history. The retardation of coal deterioration at lowered temperatures has been reported by Beier (1983), Dutcher et al. (1985), Wu et al. (1988), Huggins and Huffman (1989), and Davidson (1990).

\section{Computerized Inventory Tracking}

At the completion of processing of each DECS sample, data (bag number, weight, mesh size, storage location, etc.) for each foil laminate bag are entered in a computerized inventory program. When an order for samples is received, the program is queried and the locations, weights and particle sizes of the available bags are displayed or printed. After the bags desired have been removed from the physical inventory, the program is used to transfer their entries to a separate transactions file, and data identifying the recipient are added and stored there as well. Summaries of samples distributed and their recipients may be created from the transactions file. 
The program used under the contract stores its files in the format of a commercial data management package, so both the main file and the transactions file can be examined and manipulated with a wide range of commands if the inventory program does not provide the functions required. This is also the format of the Coal Database, so although the inventory and the Database are normally completely separate, they can be merged if needed for specific tasks.

Use of these programs after December 31, 1999, will be curtailed and will be terminated before June 1, 2000, because of year 2000 compliance problems and limited usage of the operating system under which they run. Like the Penn State Coal Database (see Task 2A), after the completion of the subject contract the data files were transferred to personal computers for continued use.

\section{Task 1C. Monitoring of Sample Condition after Storage}

The final report for the previous contract (Davis and Glick, 1993) detailed the studies of deterioration of coal samples in conventional containers, and subsequent testing and adoption of foil multilaminate bags for storage of all DECS samples. These bags were suggested for coal sample storage durations of one month by Sharp (1986). Under the previous contract, their success in preserving samples for up to 3 years was demonstrated. In the subject contract, monitoring was continued in order to examine preservation over a longer term (up to 9 years for the earliest DECS samples) for samples with a variety of sulfur contents, calorific values, and thermoplastic behavior. Processing and sealing of DECS samples under argon in foil multilaminate bags is described under Task 1D. PSOC samples were not tested, as extensive analyses had been performed under the previous contract and the storage containers used for PSOC samples have been superseded.

DECS samples were tested by a variety of methods as described below. Appendix A presents the results of up to nine years of monitoring which was instituted with initial analyses of the first DECS samples in 1990. Under the previous contract and the first year of the subject contract, all DECS samples were monitored each year. Following funding reductions, the number was reduced to 10 samples per year, selected to represent groups of samples based on rank, sulfur content, and thermoplastic behavior. In some annual monitoring programs, additional samples were analyzed for specific research goals.

Table 1 shows ASTM repeatability and reproducibility values for analyses used in monitoring. See the appropriate ASTM standard (ASTM, 1998) for details on application of the values shown. In general, it is the reproducibility values which are appropriate for evaluating results in this study, because over a period of several years, equipment and operators are likely to change, even though the same laboratory continued to provide each specific analysis through the entire study. 
Table 1. ASTM repeatability and reproducibility values

\begin{tabular}{|c|c|c|}
\hline ASTM Procedure & Repeatability & Reproducibility \\
\hline $\begin{array}{r}\text { Moisture, D3173-87 } \\
\text { coals }<5 \% \text { moisture } \\
\text { coals }>5 \% \text { moisture }\end{array}$ & $\begin{array}{l}0.2 \\
0.3\end{array}$ & $\begin{array}{l}0.3 \\
0.5\end{array}$ \\
\hline $\begin{array}{l}\text { Volatile Matter D3175-89a, \% } \\
\text { anthracite } \\
\text { semianthracite and bituminous } \\
\text { subbituminous } \\
\text { lignite }\end{array}$ & $\begin{array}{l}0.3 \\
0.5 \\
0.7 \\
1.0\end{array}$ & $\begin{array}{l}0.6 \\
1.0 \\
1.4 \\
2.0\end{array}$ \\
\hline Ash, D3174-97, \% & 0.22 & 0.32 \\
\hline Total Sulfur, D4239-97 method C (IR), \% & $0.02+0.03 \bar{x}$ & $0.02+0.09 \overline{\mathrm{x}}$ \\
\hline $\begin{array}{l}\text { Calorific Value (dry basis), D2015-96 } \\
\text { bituminous } \\
\text { subbituminous and lignite }\end{array}$ & $\begin{array}{l}39 \mathrm{cal} / \mathrm{g}(69 \mathrm{Btu} / \mathrm{lb}) \\
33 \mathrm{cal} / \mathrm{g}(59 \mathrm{Btu} / \mathrm{lb})\end{array}$ & $\begin{array}{l}60 \mathrm{cal} / \mathrm{g}(107 \mathrm{Btu} / \mathrm{lb}) \\
78 \mathrm{cal} / \mathrm{g}(140 \mathrm{Btu} / \mathrm{lb})\end{array}$ \\
\hline $\begin{array}{l}\text { Forms of Sulfur, D2492-90 } \\
\text { Sulfate, } \% \\
\text { Pyritic, } \%\end{array}$ & $\begin{array}{c}0.02 \\
0.08+0.09 \overline{\mathrm{x}}\end{array}$ & $\begin{array}{c}0.04 \\
0.15+0.27 \bar{x}\end{array}$ \\
\hline $\begin{array}{l}\text { Gieseler Plastometer, D2639-90 } \\
\text { Temperature points, }{ }^{\circ} \mathrm{C} \\
\text { Fluidity, ddpm }\end{array}$ & $\begin{array}{c}5 \\
0.1 \bar{x}\end{array}$ & $\begin{array}{l}\text { not specified } \\
\text { not specified }\end{array}$ \\
\hline Carbon, D3178-89, \% & 0.3 & not specified \\
\hline Oxygen, D3176-89, \% & not specified & not specified \\
\hline
\end{tabular}

\section{Proximate Analysis}

Short proximate (moisture and ash) analyses were performed in each case. The use of foil laminate bags for coal samples had initially been demonstrated to preserve moisture and calorific value in subbituminous coals for storage times of one month (Sharp, 1986). Appendix A shows that moisture levels are preserved well for the length of the study; in particular, see 
samples DECS-1, -8, -10, and -11, the low-rank, high-moisture samples which have been monitored over a period of at least eight years. Although the variation in readings is slightly beyond ASTM reproducibility limits, there is no trend of moisture loss.

Ash yield was not investigated as an indicator of preservation, but does serve as an indicator of the representative splitting which was performed, and would be needed if calculations for an ash-free or mineral-matter-free basis of expression were performed.

Volatile matter was not monitored each year but final values after storage are available for selected samples and can be compared to initial values (Table 2).

Table 2. Changes in volatile matter, carbon and oxygen after storage in foil laminate bags.

\begin{tabular}{||c|c|c|c|c|c|c|c||}
\hline \hline \multirow{2}{*}{ DECS } & \multirow{2}{*}{$\begin{array}{c}\text { years in } \\
\text { storage }\end{array}$} & \multicolumn{2}{|c|}{$\begin{array}{r}\text { Volatile Matter, } \\
\% \text { dry coal }\end{array}$} & \multicolumn{2}{c|}{$\begin{array}{c}\text { Carbon, } \\
\text { dry coal }\end{array}$} & \multicolumn{2}{c|}{$\begin{array}{c}\text { Oxygen (by difference), } \\
\text { dry coal }\end{array}$} \\
\cline { 3 - 8 } & & initial & final & initial & final & initial & final \\
\hline 1 & 9.1 & 47.40 & 49.57 & 62.53 & 62.79 & 14.69 & 16.87 \\
2 & 8.9 & 38.14 & 37.39 & 65.49 & 64.90 & 8.16 & 8.89 \\
3 & 8.6 & 27.19 & 27.29 & 82.68 & 83.24 & 4.09 & 4.14 \\
5 & 8.4 & 40.33 & 40.56 & 72.70 & 72.47 & 12.11 & 12.36 \\
8 & 8.4 & 45.23 & 43.80 & 64.14 & 65.52 & 15.93 & 16.65 \\
10 & 8.2 & 41.67 & 46.78 & 68.37 & 67.41 & 13.30 & 13.48 \\
11 & 8.1 & 56.08 & 54.41 & 66.15 & 65.93 & 18.62 & 21.45 \\
12 & 8.6 & 36.02 & 36.48 & 74.78 & 73.97 & 7.51 & 8.01 \\
14 & 8.1 & 32.59 & 33.10 & 76.24 & 76.55 & 5.25 & 4.98 \\
17 & 7.6 & 46.75 & 47.61 & 76.25 & 75.81 & 9.65 & 10.16 \\
18 & 7.3 & 41.18 & 40.53 & 69.39 & 69.83 & 7.80 & 8.69 \\
19 & 6.6 & 18.31 & 18.08 & 85.74 & 85.30 & 3.16 & 3.04 \\
21 & 5.8 & 4.51 & 4.31 & 80.26 & 84.05 & 3.82 & 1.96 \\
23 & 3.6 & 39.42 & 40.57 & 74.21 & 73.70 & 6.03 & 6.09 \\
24 & 3.0 & 40.83 & 42.78 & 66.05 & 66.85 & 9.30 & 8.03 \\
25 & 4.5 & 41.98 & 42.51 & 65.76 & 65.19 & 16.13 & 21.00 \\
29 & 3.6 & 34.30 & 34.33 & 81.08 & 81.13 & 5.31 & 5.59 \\
30 & 3.6 & 30.13 & 30.40 & 84.41 & 83.61 & 4.25 & 5.02 \\
33 & 3.6 & 43.06 & 43.57 & 69.51 & 69.05 & 8.43 & 8.89 \\
\hline
\end{tabular}




\section{Sulfur Forms}

Sulfur forms analyses were conducted in order to monitor the oxidation of sulfides (pyritic sulfur) to sulfates. This is a sensitive indicator of deterioration of coal samples in storage (Huffman et al., 1985); poorly protected high-sulfide samples can experience oxidation of half of their pyritic sulfur to sulfates over a period of several years (Davis and Glick, 1993). Starting with 0.00 or 0.01 percent sulfate sulfur in the coal, they may reach 1.0 to 2.0 percent after 5 years. Stored under argon in foil laminate bags, most samples show no trend of increase, and only random changes within a 0.06 percent range. Figure 1 shows linear regression trends for the 12 samples stored and analyzed at least 4 times over a period of at least 5 years. All but two of these samples yield a regression line which does not differ from $0.00 \%$ by more than the $0.04 \%$ ASTM reproducibility limit for at least 10 years. DECS-15 is within $0.04 \%$ of its lowest measured value $(0.02 \%)$ for that time period. The only outlier is DECS-18, a high pyritic sulfur coal from the Interior Coal Province. After 4 years of $0.04 \%$ sulfate sulfur or less, its final two monitoring analyses (Appendix A) yielded levels above $0.10 \%$, causing the steep slope of the regression line.

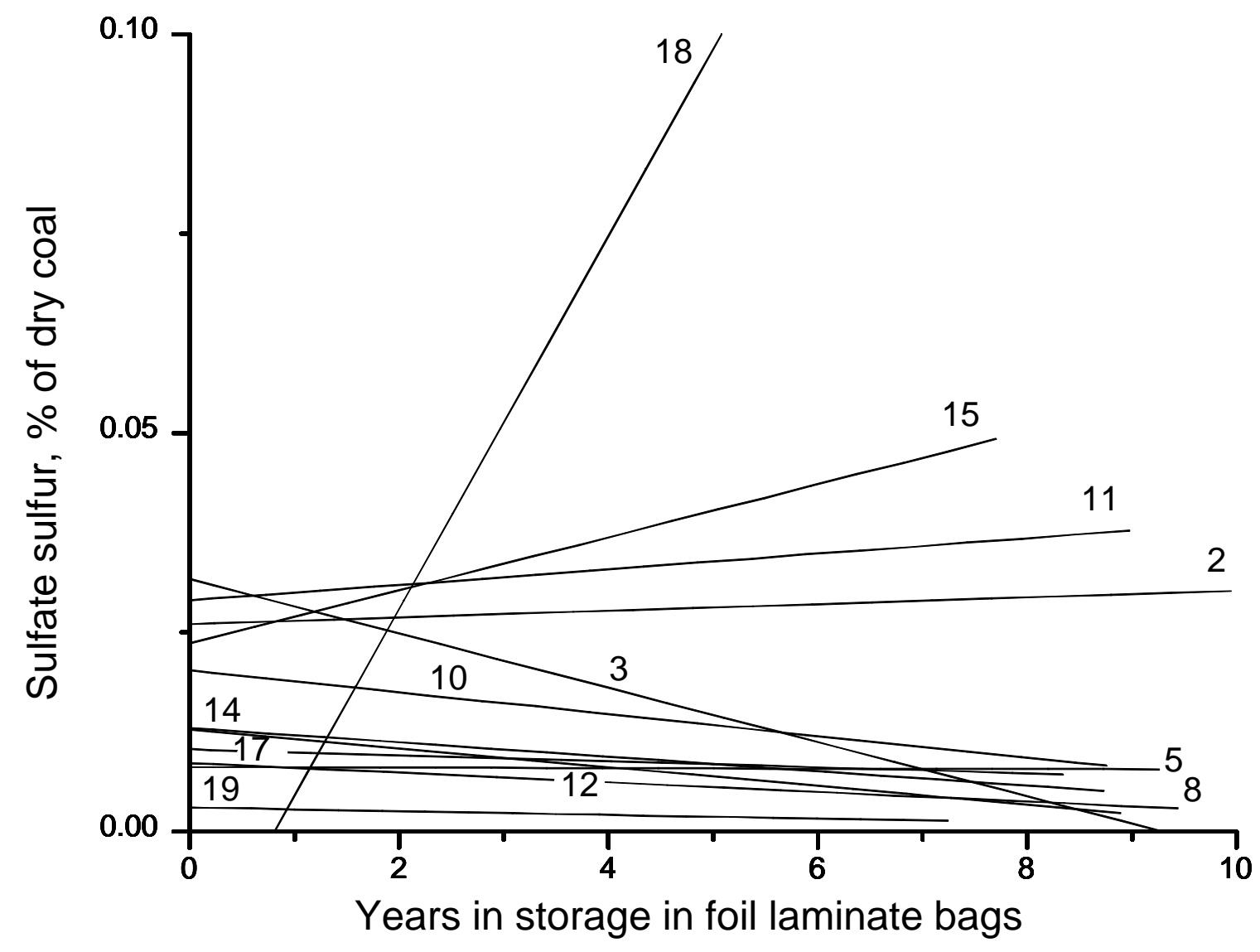

Figure 1. Change in sulfate sulfur after storage in foil laminate bags (linear regression lines). Numeric labels indicate DECS sample numbers. 


\section{Calorific Value}

Calorific value is a useful indicator of deterioration, particularly for those samples which do not exhibit fluid behavior or high pyritic sulfur levels. Poorly protected samples may lose 100 Btu/lb on a dry basis (the ASTM reproducibility limit) per year (Davis and Glick, 1993). Figure 2 shows the succession of calorific value analyses for 12 samples measured over at least 7 years.

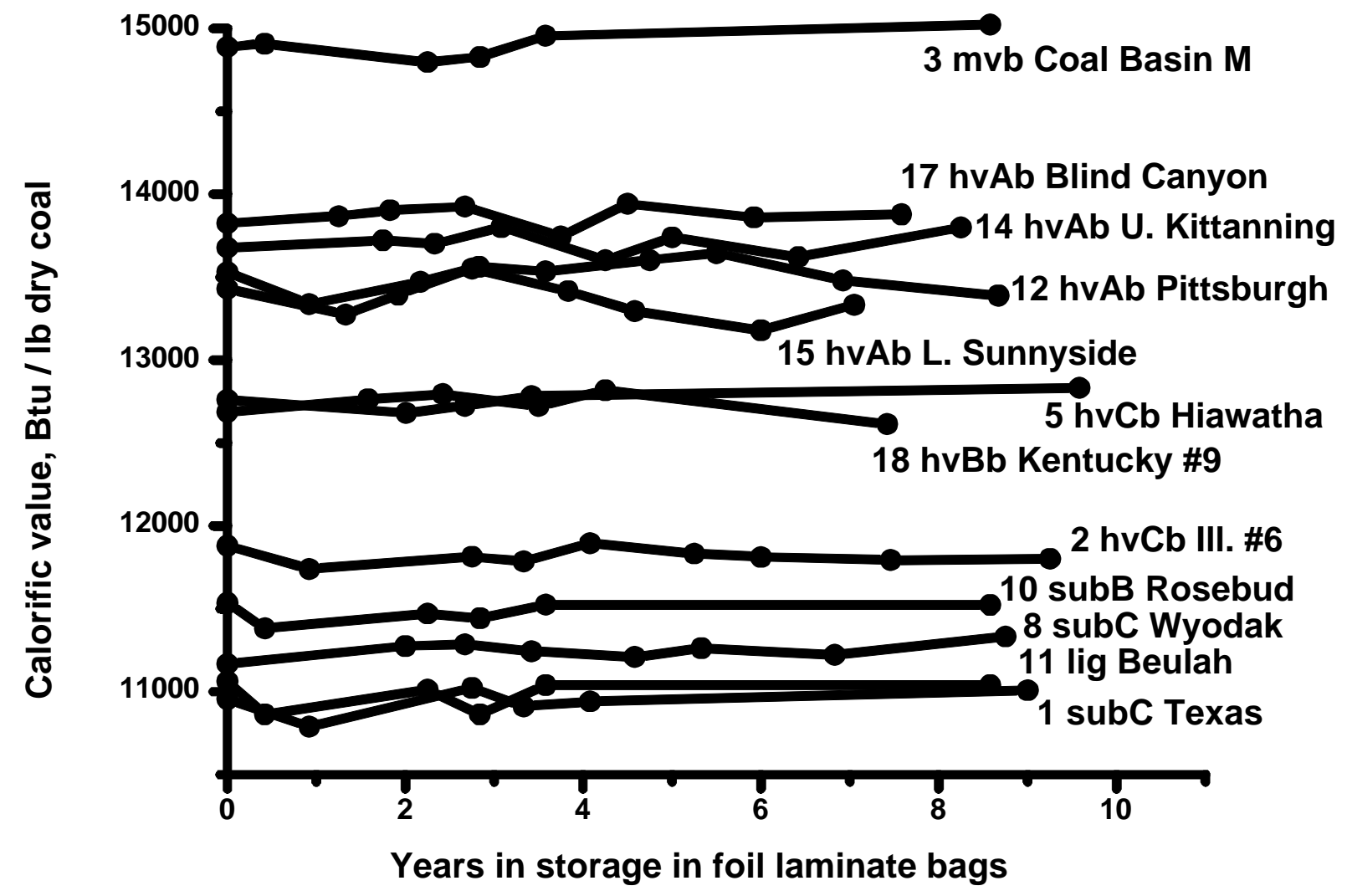

Figure 2. Change in calorific value after storage in foil laminate bags. Numeric labels represent DECS sample numbers.

\section{Gieseler Plastometry}

Thermoplastic behavior as measured by the Gieseler plastometer is another sensitive indicator of deterioration, but can only be used for those bituminous coal samples which exhibit fluidity upon heating. Davidson (1990) notes the agreement between many researchers on the sensitivity of this technique. The analysis provides an initial and final temperature between which fluidity occurs, and from which a fluid temperature range can be calculated, as well as a maximum amount of fluidity. Both fluid temperature range and the maximum fluidity decrease as coal deteriorates in storage, but the former is a more stable indicator and was used in this 
study. Poorly protected samples vary in their loss of fluid temperature range, but it is typical for half of the range to be lost in two to three years (Davis and Glick, 1993). Figure 3 includes all DECS samples monitored by Gieseler plastometry over at least 7 years. New data for PSOC1536, the medium volatile bituminous sample used in the preliminary study under the previous contract, are also included. The figure shows that storage under argon in foil laminate bags preserves fluid temperature range well for most samples.

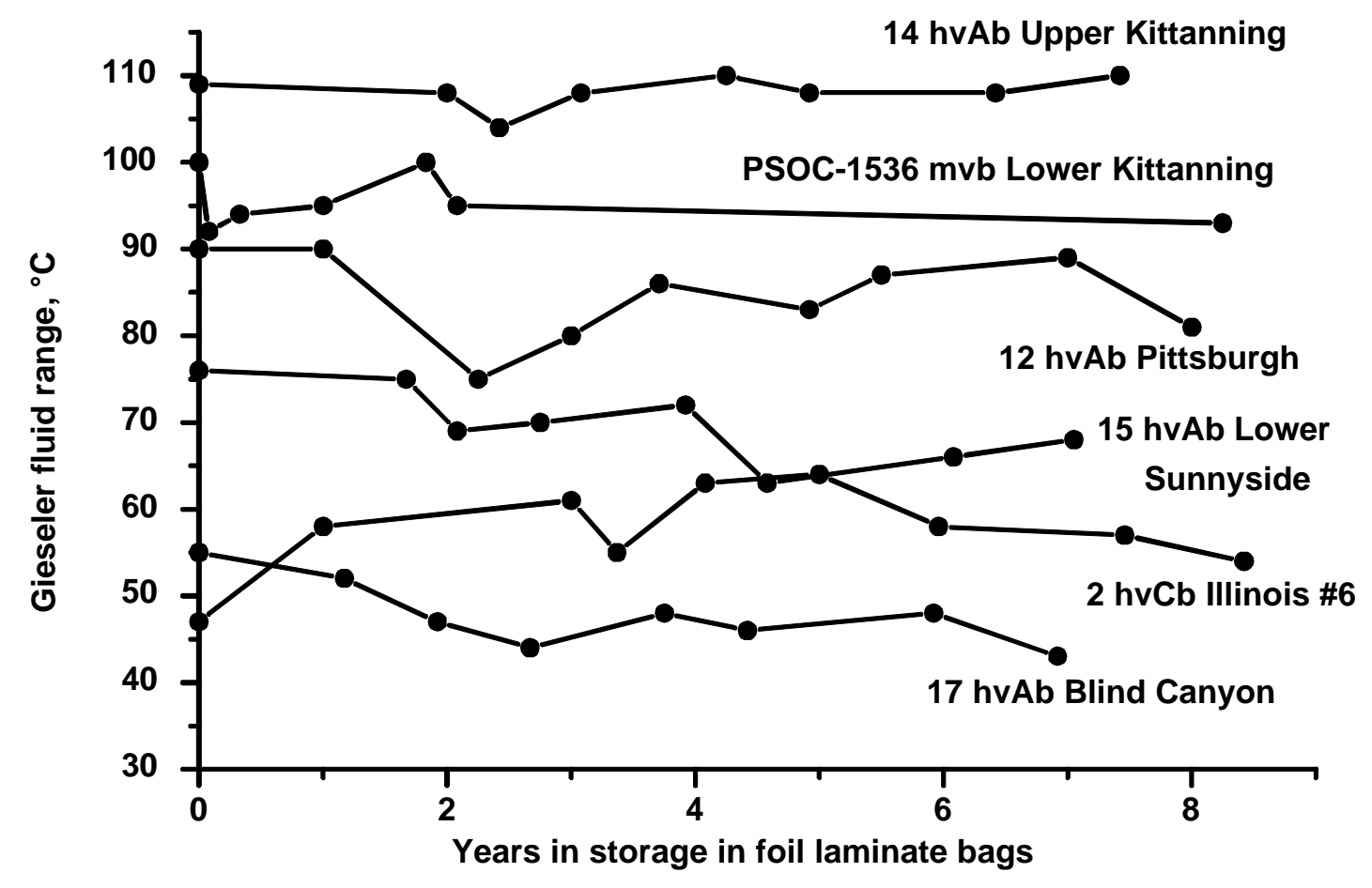

Figure 3. Change in Gieseler fluid range after storage in foil laminate bags. Numeric labels represent DECS sample numbers.

\section{Gaseous Oxygen}

A polarographic analyzer was used to measure gaseous oxygen within the foil laminate bags just prior to their being opened for analysis. These results are shown in Appendix A. Nearly every result showed oxygen to be below $0.10 \%$, so no trends could be discerned.

\section{Ultimate Analysis}

Ultimate analysis was not used routinely but initial (as part of basic analysis) and final data are available for 19 samples. Table 2 shows the change in carbon and oxygen with time in storage. Relationships between $\mathrm{C}, \mathrm{O}$, and the other indicators described above were investigated, however, the efficiency of foil laminate bag storage in preserving these indicators hindered observation of such relationships. Variability in oxygen values, caused by accumulation of errors in its calculation by difference from other values in the ultimate analysis, also contributes 
to the difficulties. Figures 4 and 5 illustrate that changes in $\mathrm{C}$ and $\mathrm{O}$ may be positive or negative, and tend to center near zero change, even after several years in storage.

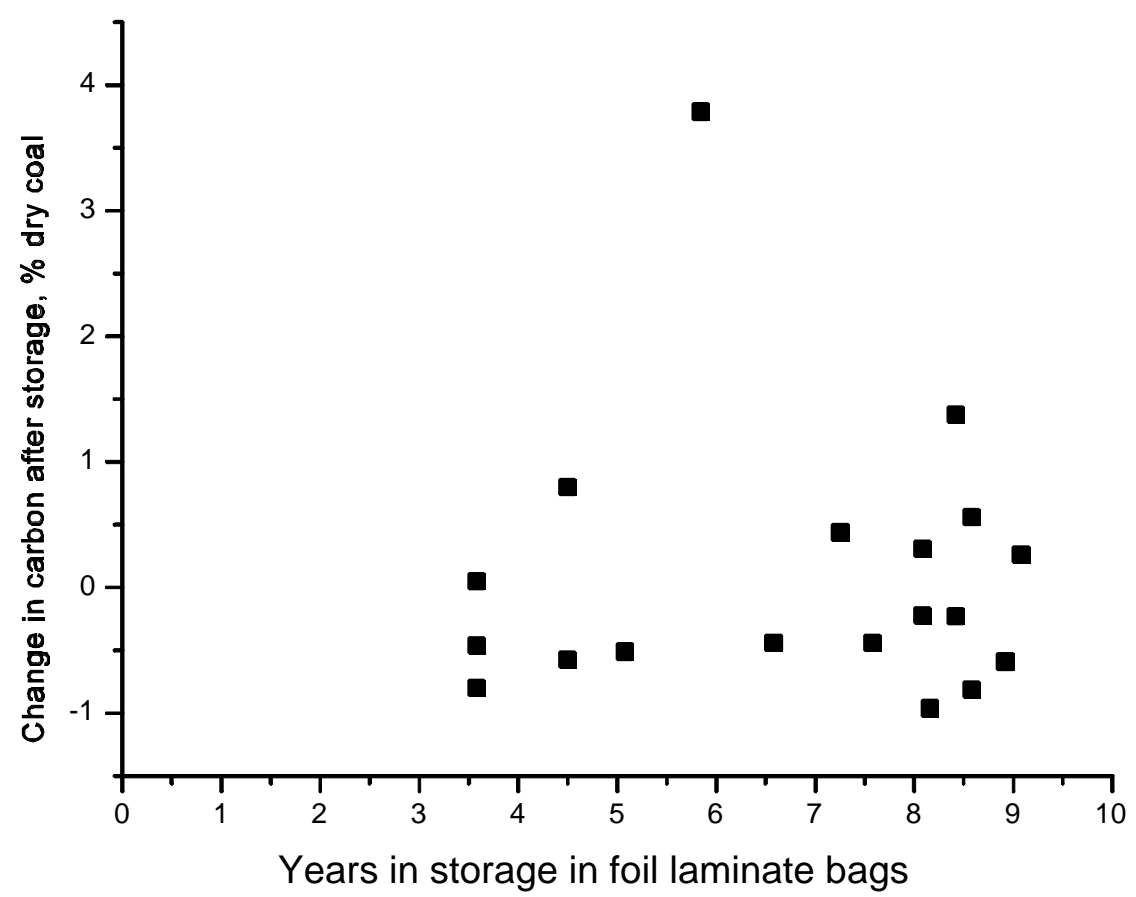

Figure 4. Change in carbon after storage in foil laminate bags

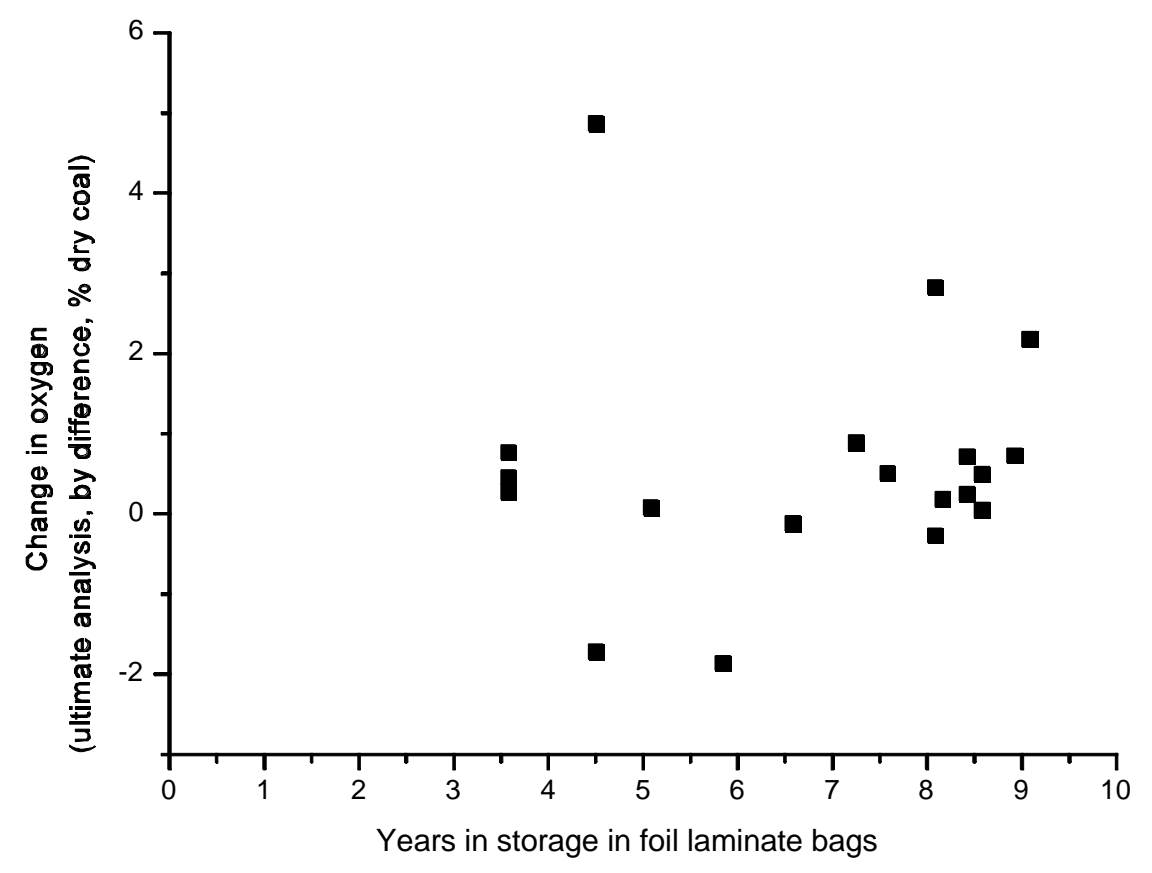

Figure 5. Change in oxygen after storage in foil laminate bags 
Among the stronger relationships is that between change in carbon and change in calorific value. Figure 6 shows that samples which lost calorific value during their years in storage tended to also lose carbon, and those which gained calorific value also tended to gain carbon.

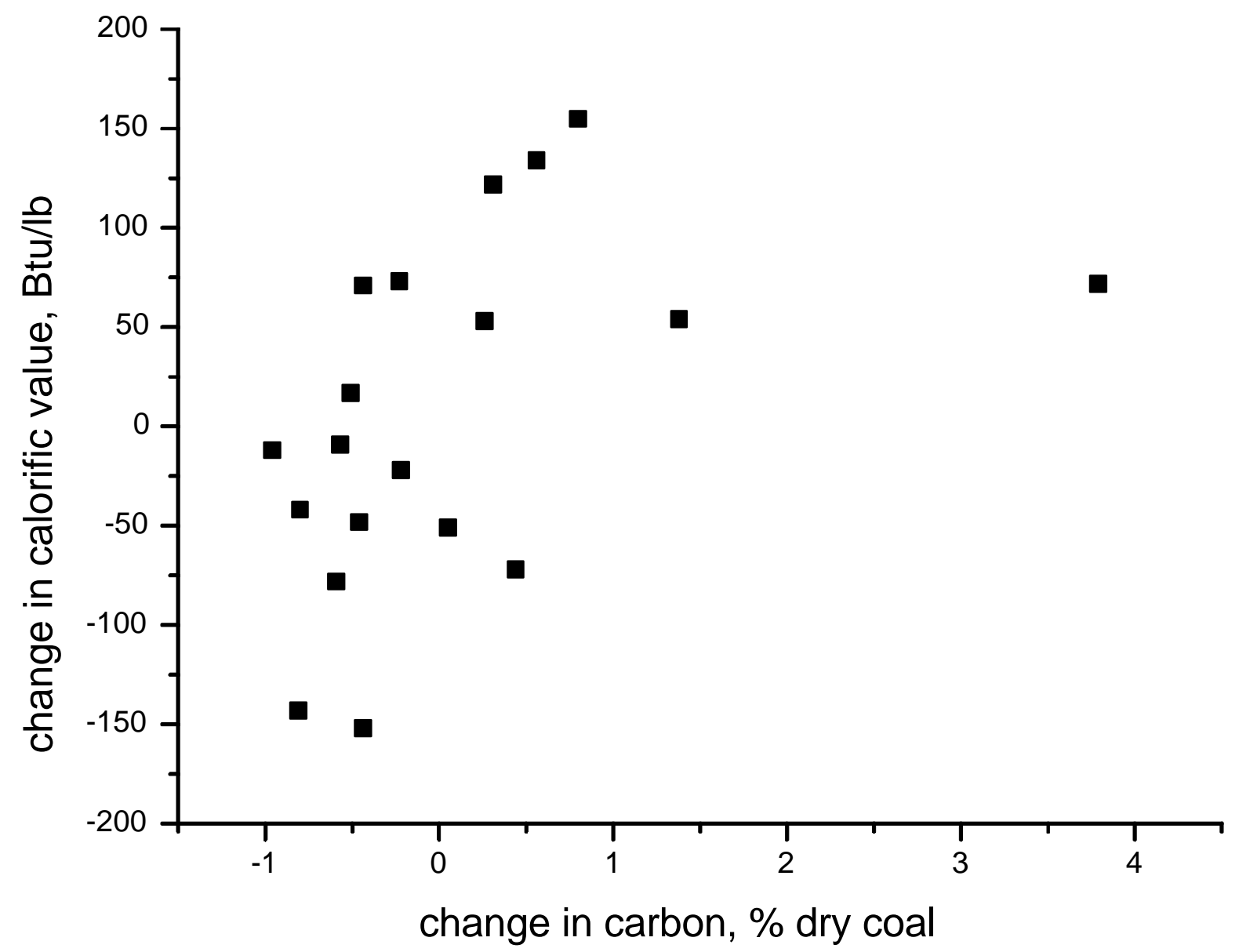

Figure 6. Change in calorific value with change in carbon for DECS samples monitored.

\section{Task 1D. Collection and Processing of Replacement Samples}

Samples were collected to replace PSOC samples from earlier contracts. The goal in each case was to collect a sample which represented the entire thickness of the seam. Whenever feasible this was achieved by collection of a channel sample of the full seam. For particularly thick seams, lack of access to the entire seam, coupled with the quantity per unit thickness required to achieve a representative sample, made a channel sample inappropriate. In these cases a run-ofmine sample (DECS-26) or drill cutting sample (DECS-27) was collected. Collection was undertaken from active sections of mines in order to obtain fresh, recently exposed coal. Each 
sample was collected by Penn State personnel in order to ensure consistent methods for collection and immediate efforts to minimize deterioration.

Bulk samples of at least $180 \mathrm{~kg}(400 \mathrm{lb})$ were placed in steel drums outfitted with highdensity lid gaskets and valved inlet and outlet ports as shown in Figure 7. This method was a modification of that used for the Illinois Basin Coal Sample Program (Harvey and Kruse, 1988; Kruse, 1989). The valve bodies were machined so that the valve body outside the drum lid and the O-ring sealing fixture inside the lid held the sheet metal of the drum lid securely between them. Two such assemblies (inlet and outlet ports) were fitted to holes in the drum lid. The inlet port had a stainless steel tube extending through the coal to the bottom of the drum for argon introduction. The outlet port provided a valved hole for the air to escape at the opposite end of the container from the argon introduction tube. During purging, argon flowed from the tube at the bottom of the drum up through the coal sample, displacing the lighter air and expelling it at the outlet port. The valves were closed to capture a slight positive pressure of argon inside the drum, and this pressure was monitored periodically while the drums were in the contractor's possession in the field to determine whether additional argon was needed to maintain positive pressure and prevent infiltration of air. This storage method was used only until the samples were returned to Penn State and processing began.

Where large blocks of coal were available for collection at the mine, a number of these were also obtained and sealed in foil laminate bags purged with argon. Such blocks will not match perfectly with the analysis of the bulk sample because of the natural heterogeneity of coal seams, but they are required for certain research. There has been a significant demand for these blocks.

\section{Samples and Sample Types Collected}

The contract had been intended to replace the 34 remaining PSOC samples funded by DOE, but reductions in funding lead to only 11 new samples being collected. In combination with the 22 existing DECS samples, the 11 were selected to achieve a balance of ranks, geographic representation, geologic age and characteristics, organic components, and inorganic composition, as well as correspondence to the Argonne Premium Coal Sample series (Table 3). After approval by DOE, the samples described below were collected.

DECS-24 is a whole-seam channel sample of the hvCb Illinois \#6 seam collected from an underground mine in Macoupin County, Illinois on June 2, 1994. This sample is comparable to that used for the concurrent HRI liquefaction contract, so expected demand was high and a large sample $(270 \mathrm{~kg}$ ) was therefore collected. A large quantity of associated blocks of coal, to be kept separate from the channel sample, was also colleted. These were intended to be used in particular

for Task IG and contract DE-FG22-93PC93223, Surface Properties of Photooxidized Bituminous Coals. Processing of this sample began on June 13, 1994, at Penn State. 


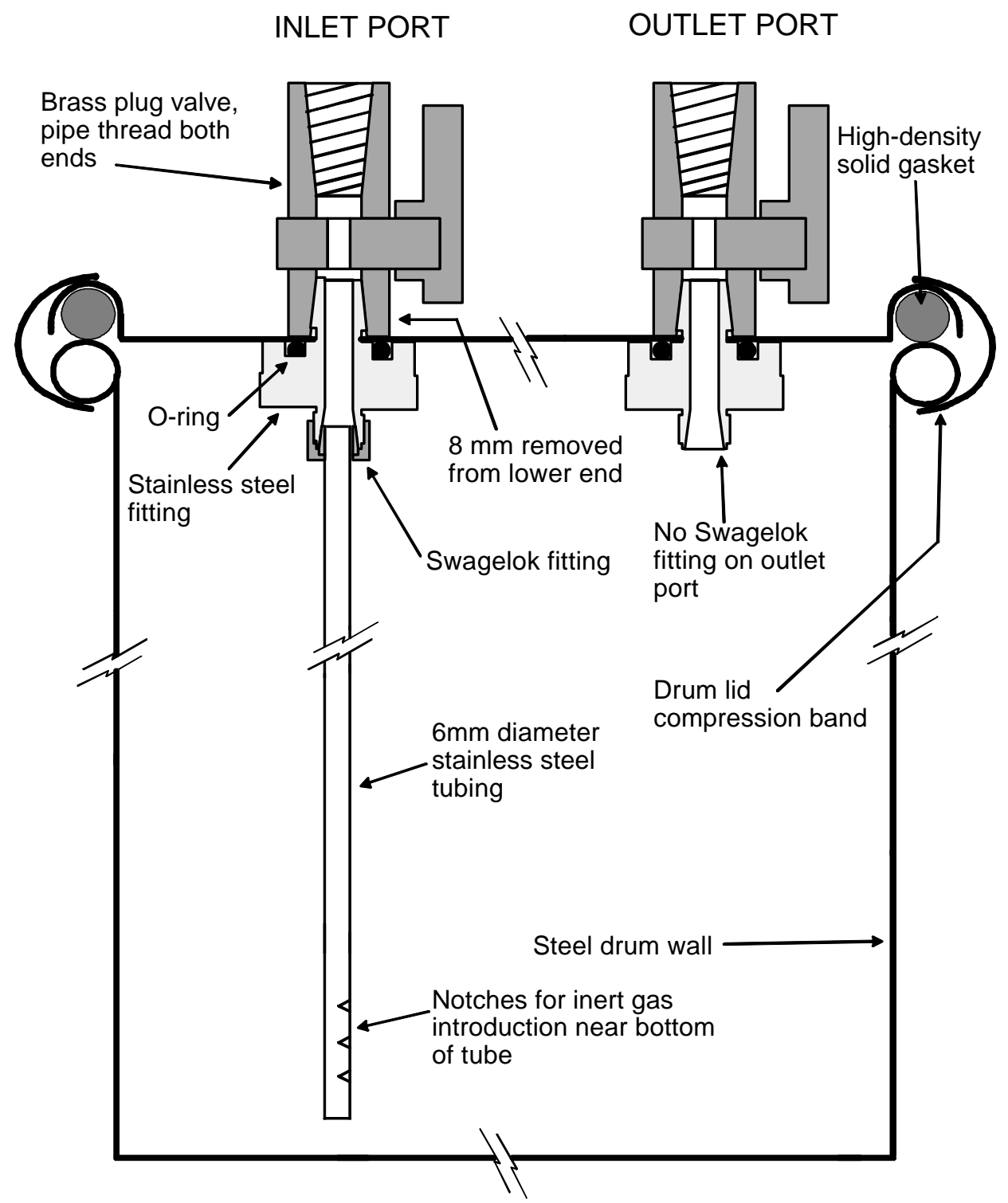

Figure 7. Apparatus for inert gas purging of samples stored temporarily in 113 liter (30 gallon) steel drums (from Davis and Glick, 1993). 
Table 3. Correspondence of Argonne Premium Coal Samples to DECS samples (Smith and Smoot, 1988; Vorres, 1989)

\begin{tabular}{|l|l|l|l|l|}
\hline $\begin{array}{l}\text { Argonne } \\
\text { Sample }\end{array}$ & \multicolumn{1}{|c|}{ Coal Seam } & State & $\begin{array}{l}\text { DECS sample from } \\
\text { same seam and mine }\end{array}$ & $\begin{array}{l}\text { DECS sample from } \\
\text { same seam, nearby mine }\end{array}$ \\
\hline APCS-1 & Upper Freeport & PA & & \\
\hline APCS-2 & Wyodak-Anderson & WY & DECS-8 & DECS-26 \\
\hline APCS-3 & Illinois \#6 & IL & DECS-2 & DECS-24 \\
\hline APCS-4 & Pittsburgh (\#8) & PA & DECS-12 & DECS-23 \\
\hline APCS-5 & Pocahontas \#3 & VA & & DECS-19 \\
\hline APCS-6 & Blind Canyon & UT & DECS-6, -16, -17 & \\
\hline APCS-7 & Lewiston-Stockton & WV & & DECS-32 \\
\hline APCS-8 & Beulah-Zap & ND & DECS-11 & \\
\hline
\end{tabular}

DECS-25 is a whole-seam channel sample of the Pust seam (lignite) in Richland County, Montana, collected on June 6, 1994. Because of the nature of the fresh exposures of coal, channel samples were collected separately from the upper and lower benches in the surface mine and combined based on the relative thicknesses of the two benches. Separate block samples were also collected.

DECS-26 is a run-of-mine sample of the subB Wyodak seam in Campbell County, Wyoming. This sample corresponds to the coal concurrently used for an HRI liquefaction project. It was collected from a surface mine on June 9, 1994, in multiple cuts from an automatic sampler on an overland conveyor belt system. A large sample was taken because demand is expected to be high for HRI samples and for Wyodak samples. Separate block samples were also collected.

DECS-27 is a whole-seam auger drill cutting sample of the subA Deadman (D-31) seam in Sweetwater County, Wyoming. It was collected from a surface mine on June 10, 1994, as a composite of material from 10 separate drill holes within a 10 meter diameter area. Blocks directly related to the sample were unavailable because of comminution of the exposed coal surface.

DECS-28 is a whole-seam channel sample of the hvCb Green seam from a surface mine in Navajo County, Arizona. It was collected June 13, 1994, and separate blocks were also taken. 
DECS-29 is a whole-seam channel sample of the hvAb Upper Banner \#3 seam collected from a surface mine in Dickenson County, Virginia, on June 19, 1995. At this site the Upper Banner is split into four separate seams, numbered 1 through 4 from bottom to top; they are exposed in separate pits in the mine. This channel sample was collected from the \#3 split; separate block samples were also collected. It was later determined that the coal was somewhat oxidized prior to collection. Initial processing of this sample was accomplished on June 28.

DECS-30 is a whole-seam channel sample of the mvb Splash Dam seam from Buchanan County, Virginia. The sample was collected on June 20, 1995, from an underground mine; the coal had been exposed less than two days prior to collection. Separate block samples were also collected. Initial processing was performed on June 29.

DECS-31 is a whole-seam channel sample of the Pond Creek seam collected on June 21, 1995, from an underground mine in Pike County, Kentucky. The coal had been exposed less than two days; block samples were also collected. Initial processing was performed on June 27.

DECS-32 is a whole-seam channel sample of the Stockton-Lewiston seam collected on June 23, 1995, from an underground mine in Kanawha County, West Virginia. The coal had been exposed approximately 20 hours prior to collection of the sample. Separate block samples were also collected. Initial processing was accomplished on June 26.

DECS-33 is a whole-seam channel sample of the Ohio \#4A seam collected from an underground mine in Meigs County, Ohio, on July 25, 1995. The coal had been exposed less than two days prior to collection. Initial processing of this sample was accomplished on July 27.

\section{Sample Processing and Packaging}

The procedures for processing of samples were similar to those developed under the previous contract (Davis and Glick, 1993) and the following discussion is drawn from that final report, incorporating changes made during the current contract. The method creates representative subsamples at three particle sizes, in foil laminate bags of appropriate size. The steel drums packed at the mine are weighed and opened. Large pieces are broken with a hammer and the entire sample is briefly air-dried if required to avoid clogging the crushing equipment. The entire sample is crushed in a hammer mill with no plate installed, to yield nominal minus $25 \mathrm{~mm}$ $(-1 ")$ particles. The general scheme, which requires some adjustment for individual samples based on total amount collected, is shown in Figure 8. These adjustments vary the fraction of coal crushed to minus $0.85 \mathrm{~mm}(-20 \mathrm{mesh})$ in order to obtain the constant quantity $(75 \mathrm{~kg}, 165$ lbs) needed for the final splits into 256 small bags.

The coal destined for the 256 bags is riffled into 8 splits, each of which is crushed to minus $0.85 \mathrm{~mm}(-20 \mathrm{mesh})$. Each split is then riffled into four, producing 32 splits of approximately 2.3 $\mathrm{kg}(5.0 \mathrm{lb})$, which are sealed under argon in foil laminate bags. Together with all splitting of minus $6 \mathrm{~mm}$ material, this constitutes the initial phase of processing, concluding with all samples sealed in foil laminate bags. 


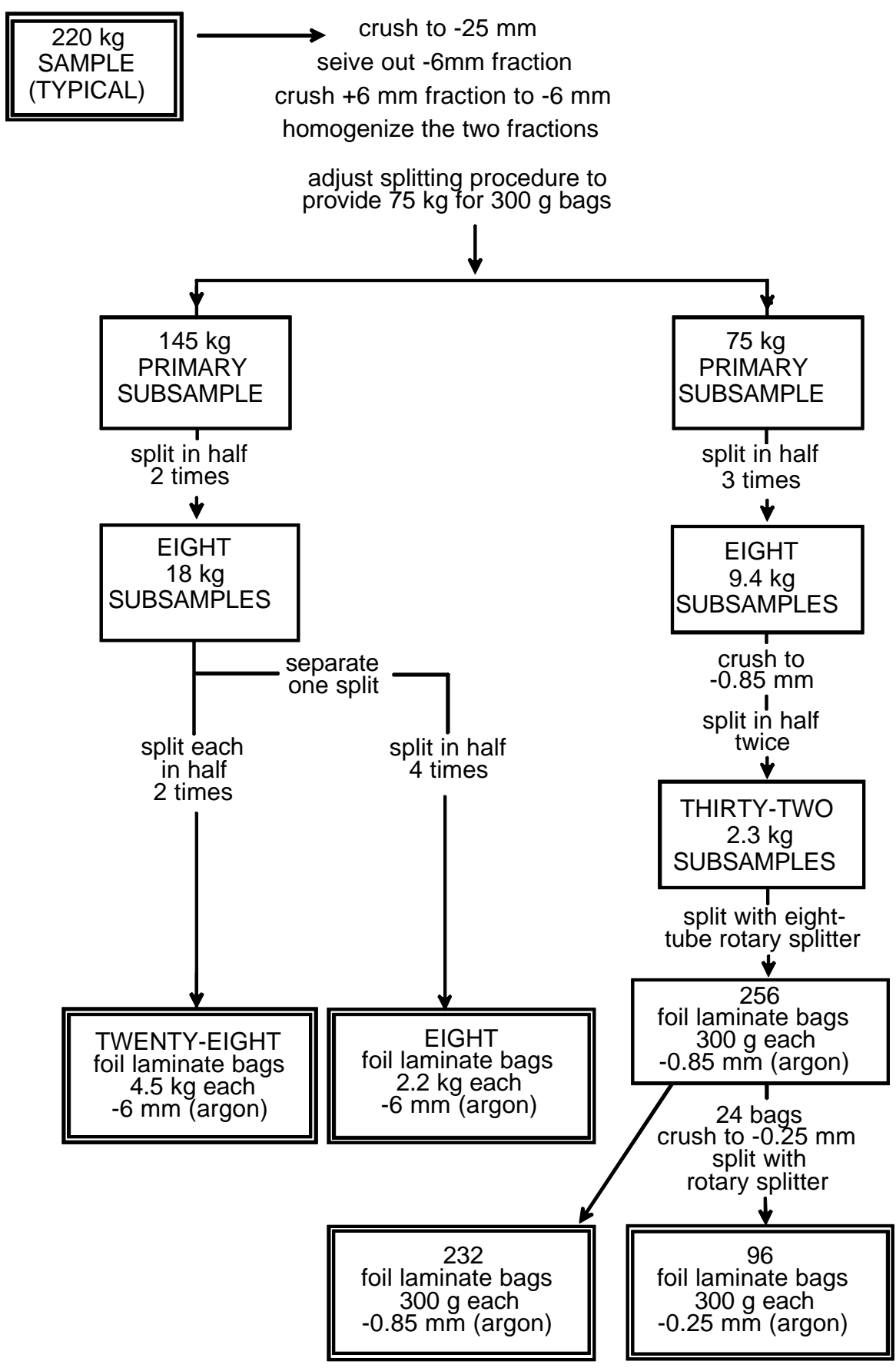

Figure 8. Typical crushing and splitting steps for a DECS sample.

For the second phase, an 8-tube rotary divider is used to divide each of the $32.3 \mathrm{~kg}$ splits at minus $0.85 \mathrm{~mm}$ into 8 final subsamples of nominally $300 \mathrm{~g}(2 / 3 \mathrm{lb})$ each. Each subsample is placed in a polyethylene bag; the bag's top is folded over once and it is placed in a labeled and 
numbered $19 \times 24 \mathrm{~cm}$ foil laminate bag. The inner unsealed bag prevents the sealing area of the foil bag, and the sealer apparatus, from being contaminated by coal particles. The bags are then placed in the chamber of a sealer which is programmed to evacuate the chamber (including the bag), introduce argon to near atmospheric pressure, and heat-seal the top of the foil bag. As the bags are removed from the sealer their weights are recorded and these are then entered in the computerized inventory. Finally, eight to 24 of the $300 \mathrm{~g}$ bags, sealed or unsealed depending upon timing, are further processed to minus $0.25 \mathrm{~mm}$ and split once more to produce $75 \mathrm{~g}$ splits. These are placed in polyethylene bags and sealed in $14 \times 24 \mathrm{~cm}$ foil bags as described above.

Under the previous contract, $75 \mathrm{~g}$ bags of minus $0.25 \mathrm{~mm}$ samples had not been produced as part of the initial processing effort. With the approval of DOE, $-0.85 \mathrm{~mm}$ portions of each of samples DECS-1 through -22 were pulverized to $-0.25 \mathrm{~mm}$, subsampled and sealed to make similar bags. All 33 DECS samples are now available at $-6 \mathrm{~mm}(-1 / 4 "),-0.85 \mathrm{~mm}$ (-20 mesh U.S.) and $-0.25 \mathrm{~mm}$ (-60 mesh U.S.).

\section{Task 1E. Basic Characterization of Coal Samples}

All samples collected were subjected to characterization using the following compositional analyses and tests:

Proximate Analysis

Ultimate Analysis

Sulfur Forms Analysis

Calorific Value Determination

Equilibrium Moisture Determination

Maceral Analysis

Vitrinite Reflectance Analysis

Ash Fusion Temperature Determination

Free-swelling Index Determination

Hardgrove Grindability Index Determination

Gieseler Plasticity Determination (for samples of bituminous rank)

Carbon Dioxide Content

Chlorine Content

Major Inorganic Elements Analysis

Trace Inorganic Elements Analysis including Hazardous Air Pollutant Elements

In addition, results of many of the above analyses were further calculated to several different bases of expression. Assignment of coal rank was performed. Information on location and collection of the sample, its field description, and related geologic information were kept associated with the analytical information. Example bivariate plots of data determined in this Task are presented in Figures 9, 10 and 11; these include data for samples collected and characterized under the previous contract in order to represent the complete set of 33 samples in the DECS series. See Task 2, The Coal Database, for further information concerning the treatment and distribution of these data under the contract. 
Non-routine characterization of the coal samples constituted a major part of the contract. See Tasks $1 \mathrm{~F}$ and $1 \mathrm{H}$ for results of liquefaction, nuclear magnetic resonance and pyrolysis / gas chromatography / mass spectrometry.

Determinations of eight hazardous air pollutant elements were performed on 22 DECS samples from the previous contract as well as the 11 collected under the current contract. Results are shown in Table 4.

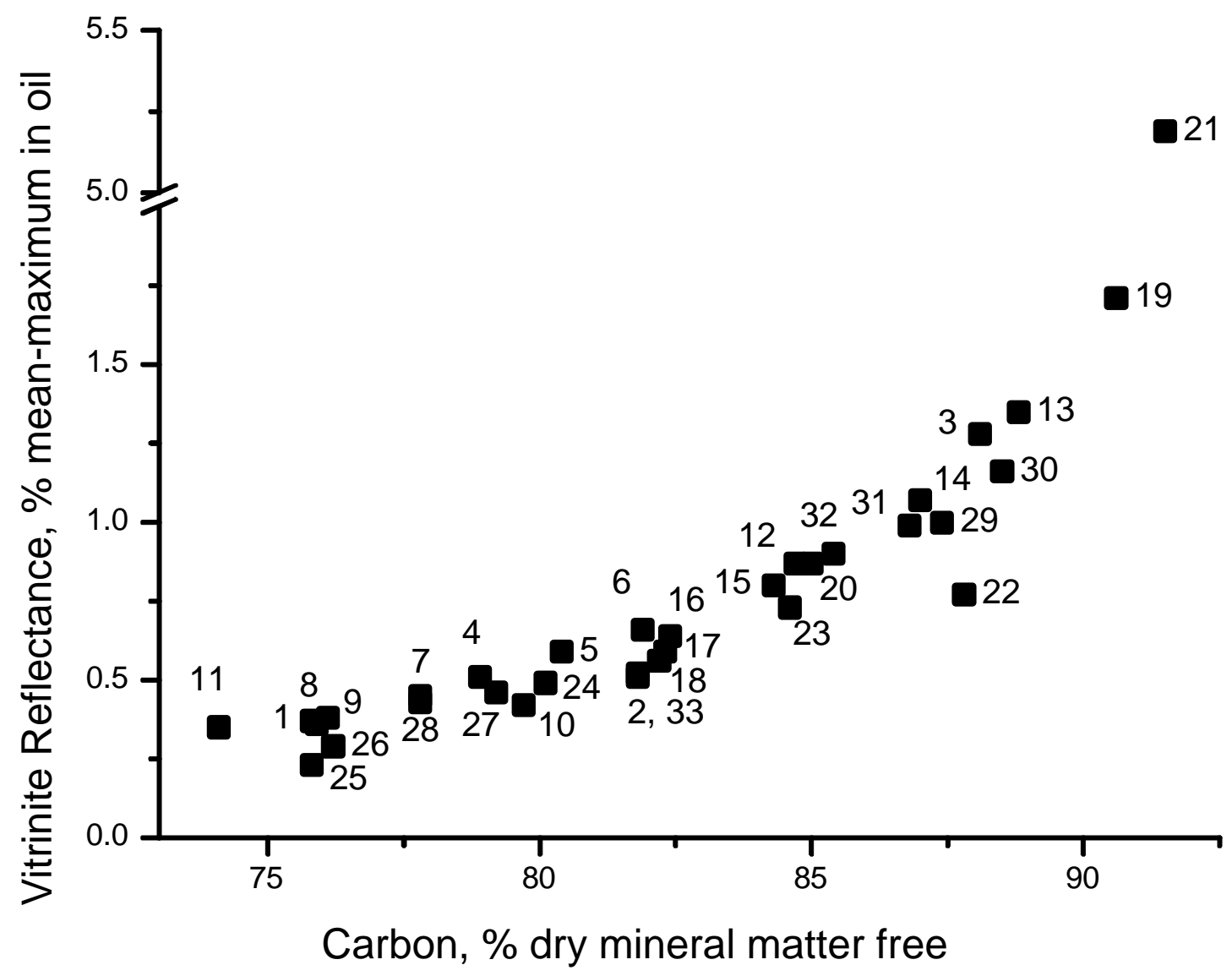

Figure 9. Vitrinite reflectance vs. carbon (numeric labels are DECS sample numbers). 


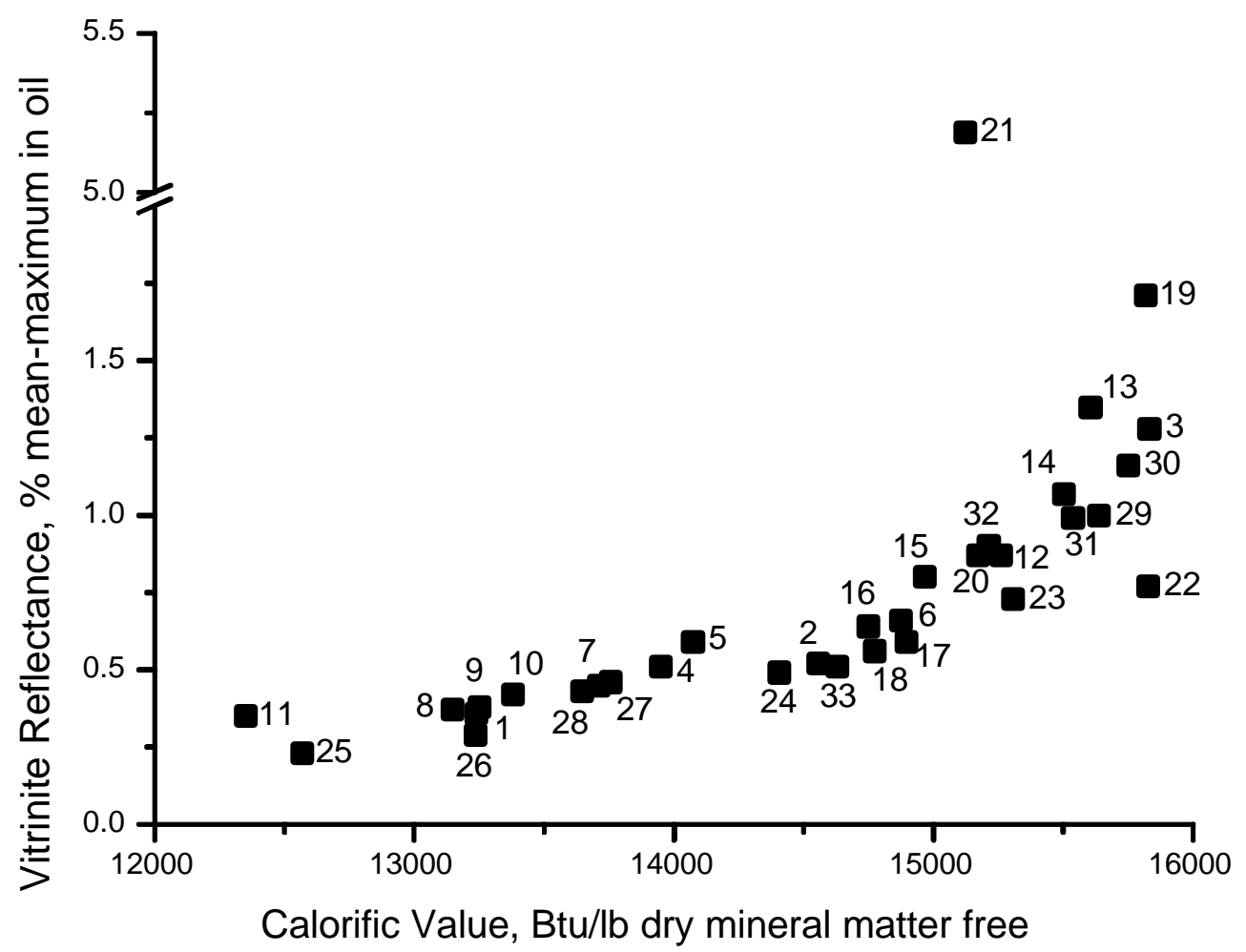

Figure 10. Vitrinite reflectance vs. calorific value (numeric labels are DECS sample numbers).

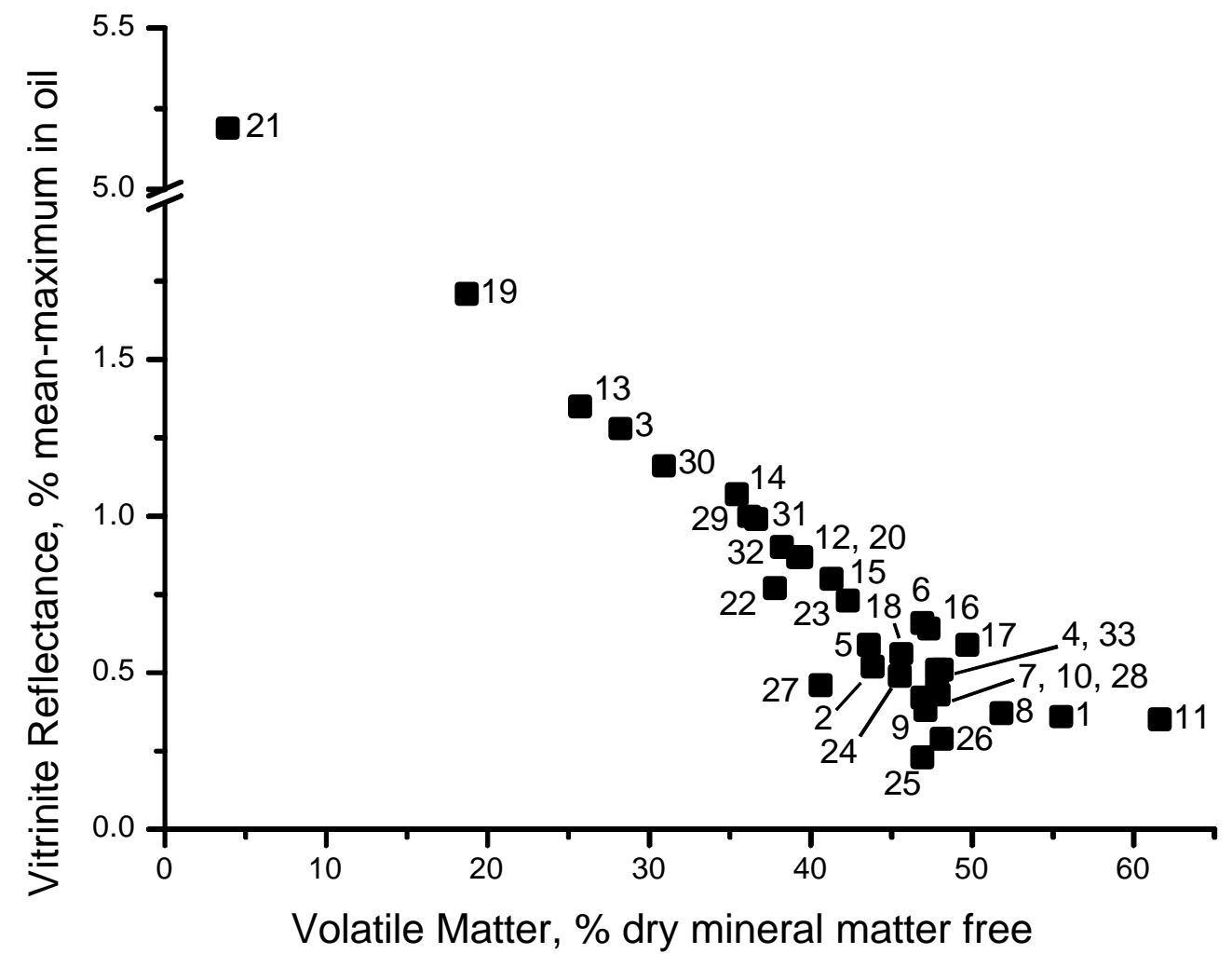

Figure 11. Vitrinite reflectance vs. volatile matter (numeric labels are DECS sample numbers). 
Table 4. Hazardous Air Pollutant Element Analyses of DECS samples, as ppm dry coal.

DECS

$\begin{array}{lllllllllll}\text { \# } & \text { St } & \text { Rank } & \text { As } & \mathrm{Ba} & \mathrm{Cd} & \mathrm{Cr} & \mathrm{Pb} & \mathrm{Hg} & \mathrm{Se} & \mathrm{Ag}\end{array}$

$\begin{array}{lllllllllll}1 & \text { TX } & \text { subC } & 3 . & 133 . & <0.2 & 8 . & 9 . & 0.17 & <1.0 & <0.2\end{array}$

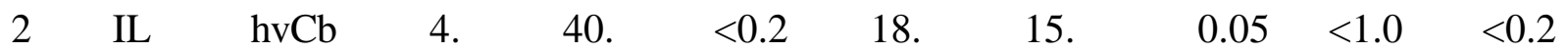

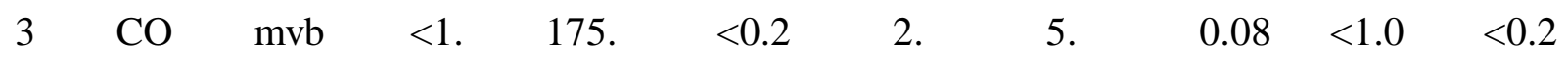

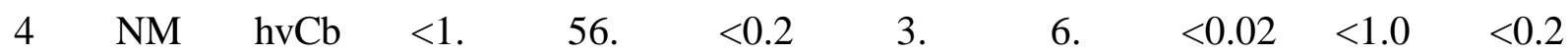

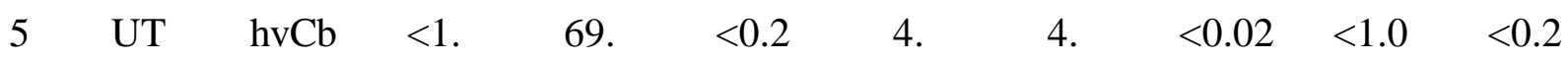

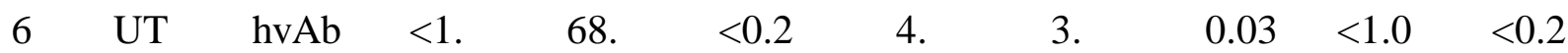

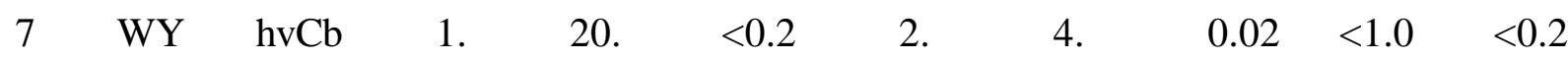

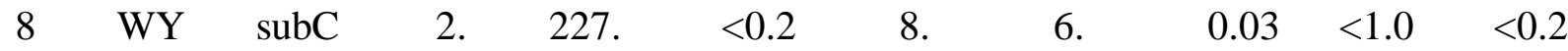

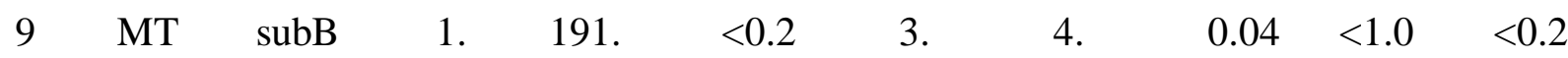

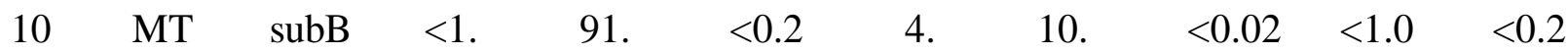

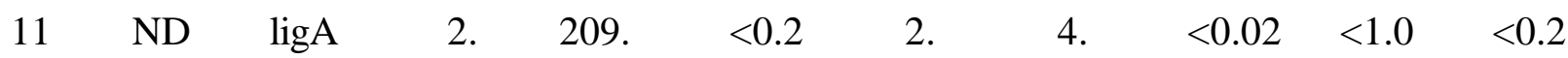

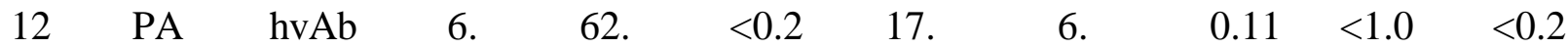

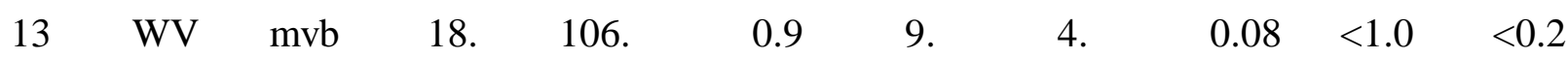

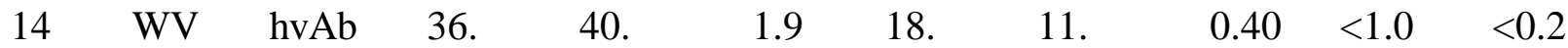

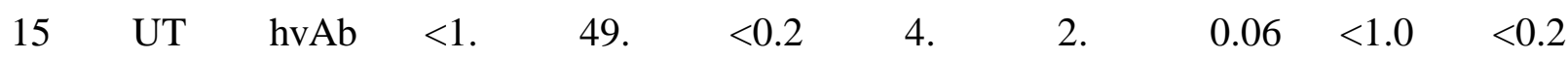

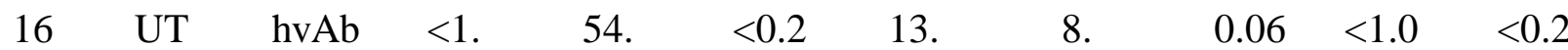

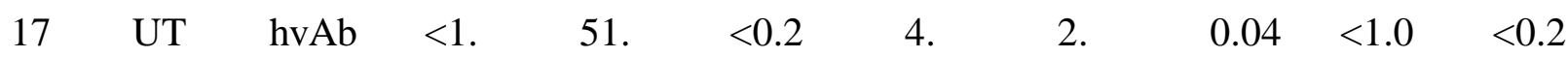

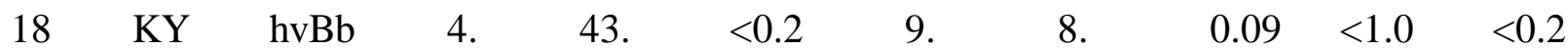

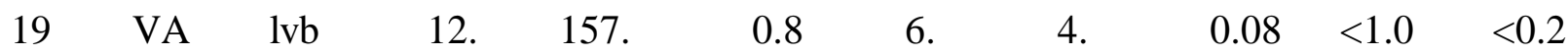

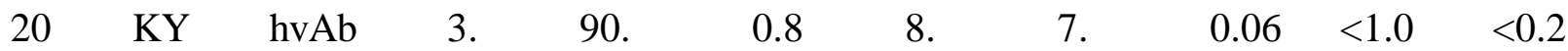

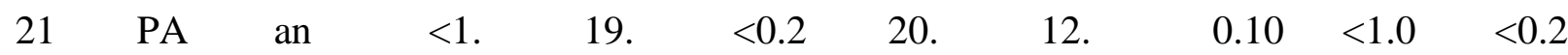

$\begin{array}{llllllllll}22 & \text { PA } & \text { hvAb 13. } & 43 . & <0.2 & 29 . & 16 . & 0.60 & <1.0 & <0.2\end{array}$

$\begin{array}{llllllllll}23 & \text { PA } & \text { hvAb 13. } & 56 . & <0.2 & 13 . & 6 . & 0.12 & <1.0 & <0.2\end{array}$

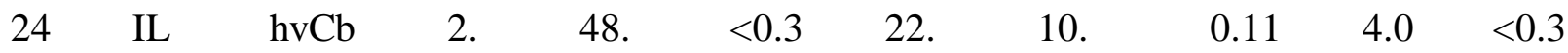

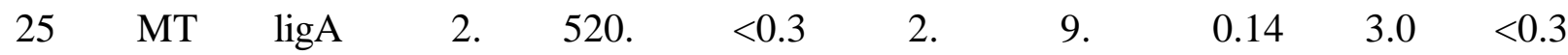

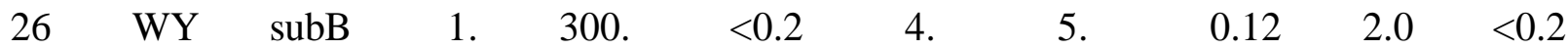

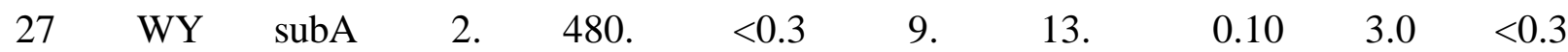

$\begin{array}{lllllllllll}28 & \mathrm{AZ} & \mathrm{hvCb} & 1 . & 310 . & <0.2 & 2 . & 5 . & 0.04 & 2.0 & <0.2\end{array}$

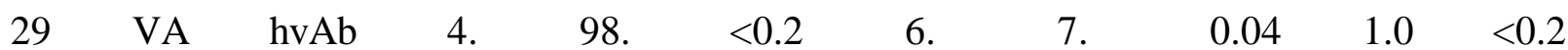

$\begin{array}{lllllllllll}30 & \text { VA } & \text { mvb } & 19 . & 74 . & <0.1 & 6 . & 4 . & 0.11 & 2.0 & <0.1\end{array}$

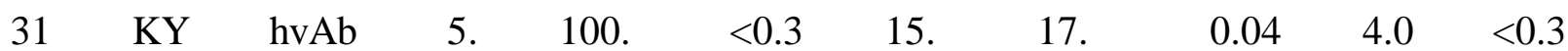

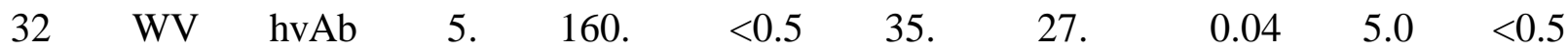

$33 \quad \mathrm{OH} \quad \mathrm{hvBb} \quad 4 . \quad 39 . \quad<0.3 \quad 16 . \quad<3 . \quad 0.09 \quad 5.0 \quad<0.3$ 


\section{Task 1F. Liquefaction Testing}

Selected DECS coal samples were subjected to a series of organic geochemical tests to provide baseline data for the various coals studied as part of this project. The tests were basically solid-state ${ }^{13} \mathrm{C}$ NMR analyses and pyrolysis/gas chromatography/mass spectrometry, described under Task $1 \mathrm{H}$, and liquefaction (using both tetralin and 1-methylnaphthalene as the solvents). The purpose of this section is to examine the liquefaction results and to develop an explanation for the trends in each data set as a function of coal rank as determined by both dry, ash-free carbon contents and mean-maximum vitrinite reflectance values.

\section{Development of a Standardized Liquefaction Test}

A procedure for a standardized liquefaction test and product workup was established; it is described step-by-step in Appendix B. The goal was to maximize the differences in liquefaction behavior and products which might be observed among different coals, rather than to maximize yield from individual coals.

The coal samples were first freeze dried. Tubing-bomb reactor tests were performed in duplicate with $5 \mathrm{~g}$ coal and 5g 1-methylnaphthalene or tetralin per reactor under $1000 \mathrm{psig}_{2}$, run in a sand bath at $350^{\circ} \mathrm{C}$ for $30 \mathrm{~min}$. When the tubing bombs were opened, gas from the first bomb was used to purge the line to the collection container and the gas volume was measured. Gas from the second bomb was collected in a second container and subsequently analyzed by gas chromatography. Results are reported on an ash-free basis. The conversion values calculated were averages of two tubing bomb runs; gas component analysis data result from one tubing bomb run and were adjusted to match the average gas conversion from the two tubing bomb runs. The product workup included percentages of total conversion, volatile hydrocarbons, asphaltenes, preasphaltenes, and ash.

Of the 33 DECS samples available for study, 28 were of high volatile A bituminous or lower rank and were subjected to liquefaction. Those omitted were DECS-3 (mvb), DECS-13 (mvb), DECS-19 (lvb), DECS-21 (an), and DECS-30 (mvb).

In addition, a protocol was developed and splits of samples DECS-23 and -24 were set aside for a planned time study of liquefaction behavior as related to storage conditions, which was to be performed annually in conjunction with the monitoring of sample condition (Task 1C). Annual liquefaction runs were planned for:

1) splits remaining sealed in original foil laminate bags, under refrigeration;

2) splits exposed to the laboratory atmosphere, without refrigeration; and for samples other than DECS-24,

3) splits remaining sealed in original foil laminate bags, without refrigeration. This study was not completed because of reductions in funding, but the samples remained available at the end of the contract. 


\section{Results}

The DECS coal samples were subjected to tubing-bomb liquefaction using tetralin and 1-methylnaphthalene. The 28 coal samples examined were all liquefied in tetralin, and nine selected samples were also liquefied with 1-methylnaphthalene in a comparative study. The data for all samples are given in Tables 5 and 6 . Table 5 presents the liquefaction in tetralin while Table 6 compares the liquefaction in tetralin with that in 1-methylnaphthalene. The results of this comparison indicated that no significant differences are observed between liquefaction conversions, asphaltene, preasphaltene, oil, and gas contents in replicate situations for the same respective coals. This result indicated that liquefaction data with tetralin as solvent generally provided the equivalent yields as liquefaction with 1-methylnaphthalene and it is this former data set that will be discussed below.

Table 5 provides the data for conversions into the various components. Total liquefaction conversion is plotted as a function of the two rank parameters, \% $\mathrm{C}$ daf and mean-maximum vitrinite $\mathrm{R}_{\mathrm{o}}$ in Figures 12 and 13. There is generally little correlation of conversion with rank, except for a generally decreasing yield in the higher rank samples that is expected. Some low-rank samples have low yields, while others have high yields. This could be related to retrogressive reactions in certain coals, perhaps induced by the higher contents of phenolics. An example of this is DECS-11, the Beulah, North Dakota, lignite known for its high content of phenolics (see NMR and pyrolysis discussions under Task $1 \mathrm{H}$ ), where a relatively low liquefaction yield is probably due to this effect. On the other hand, the low-rank DECS-1 sample from Texas shows higher yields due to the fact that it is rich in aliphatic moieties (NMR data) and depleted of phenolics (as shown by pyrolysis data).

Yields of asphaltenes, preasphaltenes, and oil (Figures 14-19) also show highly scattered plots as a function of rank and similar explanations can be provided for the lack of direct correlation. The yields of gas (Figures 20 and 21), however, show a correlation of generally decreasing yields with increasing rank, as one might expect. 
Table 5. Conversion of DECS samples in a standardized liquefaction test using tetralin (1:1 coal:tetralin, $1000 \mathrm{psig}_{2}, 350^{\circ} \mathrm{C}, 30 \mathrm{~min}$ ), with detailed gas composition (average of two runs, except gas components based on one run).

\begin{tabular}{|c|c|c|c|c|c|c|c|c|c|c|c|c|c|c|}
\hline \multicolumn{3}{|c|}{ sample } & \multicolumn{12}{|c|}{ conversion, percent of dry ash-free coal } \\
\hline \multirow[b]{2}{*}{ number } & \multirow[b]{2}{*}{ rank } & \multirow[b]{2}{*}{ St } & \multirow[b]{2}{*}{ total } & \multirow[b]{2}{*}{ asph. } & \multirow{2}{*}{$\begin{array}{l}\text { pre- } \\
\text { asph. }\end{array}$} & \multirow[b]{2}{*}{ oil } & \multirow[b]{2}{*}{ gas } & \multicolumn{7}{|c|}{ gas composition } \\
\hline & & & & & & & & $\mathrm{c} 1$ & $\mathrm{c} 2$ & c3 & c4 & c5 & c1-c5 & other \\
\hline DECS-1 & subC & $\mathrm{TX}$ & 66.3 & 12.5 & 9.2 & 8.9 & 35.7 & 8.5 & 4.0 & 1.6 & & & 14.1 & 21.6 \\
\hline DECS-2 & hvCb & $\mathrm{IL}$ & 62.7 & 9.1 & 32.7 & 8.1 & 12.8 & 6.5 & 1.6 & 1.1 & & & 9.2 & 3.6 \\
\hline DECS-4 & hvCb & NM & 48.5 & 6.1 & 11.7 & 7.6 & 23.1 & 0.5 & 0.4 & 0.2 & & & 1.1 & 22.0 \\
\hline DECS-5 & hvCb & UT & 45.0 & 6.9 & 27.2 & 6.8 & 4.1 & 0.5 & 0.4 & 0.1 & & & 1.0 & 3.1 \\
\hline DECS-6 & hvAb & UT & 30.1 & 7.9 & 7.7 & 7.0 & 7.5 & 0.5 & 0.2 & 0.1 & & & 0.8 & 6.7 \\
\hline DECS-7 & hvCb & WY & 44.6 & 8.3 & 4.9 & 10.3 & 21.1 & 1.1 & 0.6 & 0.2 & & & 1.9 & 19.2 \\
\hline DECS-8 & subC & WY & 60.2 & 6.6 & 10.9 & 11.8 & 30.9 & 9.3 & 4.8 & 1.2 & & & 15.3 & 15.6 \\
\hline DECS-9 & subB & MT & 35.0 & 6.1 & 9.1 & 4.2 & 15.6 & 0.6 & 0.4 & 0.1 & & & 1.1 & 14.5 \\
\hline DECS-10 & subB & MT & 35.5 & 7.2 & 8.6 & 4.7 & 15.0 & 0.7 & 0.3 & 0.2 & & & 1.2 & 13.8 \\
\hline DECS-11 & $\operatorname{lig} A$ & ND & 29.5 & 7.7 & 4.9 & 7.8 & 9.1 & 2.4 & 1.1 & 0.4 & & & 3.9 & 5.2 \\
\hline DECS-12 & hvAb & PA & 30.6 & 1.2 & 14.9 & 6.7 & 7.8 & 2.8 & 0.9 & 0.4 & 0.2 & 0.2 & 4.5 & 3.3 \\
\hline DECS-14 & hvAb & WV & 44.9 & 7.4 & 15.7 & 7.7 & 14.1 & 1.4 & 0.9 & 0.2 & & & 2.5 & 11.6 \\
\hline DECS-15 & hvAb & UT & 43.5 & 7.8 & 18.7 & 8.6 & 8.4 & 1.1 & 0.5 & 0.1 & & & 1.7 & 6.7 \\
\hline DECS-16 & hvAb & UT & 51.9 & 19.2 & 9.8 & 13.2 & 9.7 & 1.5 & 0.8 & 0.3 & & & 2.6 & 7.1 \\
\hline DECS-17 & hvAb & UT & 54.6 & 11.4 & 9.4 & 15.0 & 18.8 & 3.6 & 1.8 & 1.1 & & & 6.5 & 12.3 \\
\hline DECS-18 & hvBb & $\mathrm{KY}$ & 31.9 & 4.6 & 16.2 & 7.3 & 3.8 & 0.2 & 0.1 & 0.1 & & & 0.4 & 3.4 \\
\hline DECS-20 & hvAb & KY & 29.0 & 5.9 & 11.9 & 6.2 & 5.0 & 0.9 & 0.5 & 0.2 & & & 1.6 & 3.4 \\
\hline DECS-22 & hvAb & PA & 42.0 & 8.2 & 14.7 & 8.9 & 10.2 & 1.2 & 0.8 & 0.2 & & & 2.2 & 8.0 \\
\hline DECS-23 & hvAb & PA & 64.8 & 7.2 & 30.9 & 8.5 & 18.2 & 7.6 & 1.8 & 1.5 & 0.3 & & 11.2 & 7.0 \\
\hline DECS-24 & hvCb & $\mathrm{IL}$ & 62.5 & 6.9 & 35.0 & 8.8 & 11.8 & 6.3 & 2.7 & 0.6 & & & 9.6 & 2.2 \\
\hline DECS-25 & $\operatorname{lig} A$ & MT & 53.6 & 3.9 & 7.4 & 6.4 & 35.9 & 0.5 & 0.1 & & & & 0.6 & 35.3 \\
\hline DECS-26 & subB & WY & 54.6 & 5.3 & 10.1 & 6.8 & 32.4 & 0.5 & 0.1 & & & & 0.6 & 31.8 \\
\hline DECS-27 & subA & WY & 48.2 & 13.9 & 14.0 & 7.2 & 13.1 & 6.0 & 1.6 & 0.5 & & & 8.1 & 5.0 \\
\hline DECS-28* & hvCb & $A Z$ & 42.2 & 10.4 & 15.0 & 6.2 & 10.6 & 7.1 & 1.6 & 0.7 & & & 9.4 & 1.2 \\
\hline DECS-29 & hvAb & VA & 22.1 & 3.3 & 7.7 & 6.3 & 4.8 & 0.6 & 0.2 & 0.1 & & & 0.9 & 3.9 \\
\hline DECS-31 & hvAb & $\mathrm{KY}$ & 36.4 & 15.7 & 3.2 & 7.4 & 10.1 & 0.5 & 0.1 & & & & 0.6 & 9.5 \\
\hline DECS-32 & hvAb & WV & 29.8 & 4.6 & 16.3 & 6.6 & 2.3 & 0.3 & 0.1 & 0.1 & & & 0.5 & 1.8 \\
\hline DECS-33 & hvBb & $\mathrm{OH}$ & 62.8 & 27.3 & 20.4 & 12.2 & 2.9 & 0.7 & 0.4 & 0.3 & 0.1 & & 1.5 & 1.4 \\
\hline
\end{tabular}

${ }^{*}$ based on one run; second run failed 
Table 6. Conversion of DECS samples in a standardized liquefaction test, comparing results from tetralin and 1-methylnaphthalene.

\begin{tabular}{|c|c|c|c|c|c|c|c|}
\hline \multirow{2}{*}{\begin{tabular}{|l} 
sample \\
\end{tabular}} & \multirow[b]{2}{*}{ solvent } & \multirow[b]{2}{*}{ replicate } & \multicolumn{5}{|c|}{ conversion, percent of dry ash-free coal } \\
\hline & & & total & asph. & preasph. & oil & gas \\
\hline DECS-1 & tetralin & a & 65.6 & 12.4 & 8.8 & 9.0 & 35.4 \\
\hline DECS-1 & tetralin & $\mathrm{b}$ & 66.9 & 12.6 & 9.5 & 8.8 & 36.0 \\
\hline DECS-1 & tetralin & average & 66.3 & 12.5 & 9.2 & 8.9 & 35.7 \\
\hline DECS-1 & 1-methyl. & a & 64.4 & 11.2 & 9.4 & 9.0 & 34.8 \\
\hline DECS-1 & 1-methyl. & $b$ & 69.0 & 12.5 & 9.9 & 9.4 & 37.2 \\
\hline DECS-1 & 1-methyl. & average & 66.7 & 11.9 & 9.7 & 9.2 & 36.0 \\
\hline DECS-2 & tetralin & $a$ & 63.0 & 9.0 & 33.0 & 8.1 & 12.9 \\
\hline DECS-2 & tetralin & $b$ & 62.3 & 9.2 & 32.3 & 8.0 & 12.8 \\
\hline DECS-2 & tetralin & average & 62.6 & 9.1 & 32.7 & 8.1 & 12.9 \\
\hline DECS-2 & 1-methyl. & a & 62.9 & 9.0 & 31.5 & 8.6 & 13.8 \\
\hline DECS-2 & 1-methyl. & $b$ & 61.9 & 8.8 & 32.2 & 8.1 & 12.8 \\
\hline DECS-2 & 1-methyl. & average & 62.4 & 8.9 & 31.9 & 8.4 & 13.3 \\
\hline DECS-8 & tetralin & a & 62.0 & 5.6 & 11.0 & 10.8 & 34.6 \\
\hline DECS-8 & tetralin & $b$ & 58.3 & 7.7 & 10.8 & 12.7 & 27.1 \\
\hline DECS-8 & tetralin & average & 60.2 & 6.7 & 10.9 & 11.8 & 30.9 \\
\hline DECS-8 & 1-methyl. & a & 57.7 & 9.4 & 11.0 & 12.9 & 24.4 \\
\hline DECS-8 & 1-methyl. & $b$ & 59.3 & 7.5 & 11.4 & 11.0 & 29.4 \\
\hline DECS-8 & 1-methyl. & average & 58.5 & 8.5 & 11.2 & 12.0 & 26.9 \\
\hline DECS-12 & tetralin & a & 23.1 & 0.1 & 15.1 & 6.3 & 1.6 \\
\hline DECS-12 & tetralin & $b$ & 38.1 & 2.2 & 14.6 & 7.0 & 14.3 \\
\hline DECS-12 & tetralin & average & 30.6 & 1.2 & 14.9 & 6.70 & 8.0 \\
\hline DECS-12 & 1-methyl. & $a$ & 36.4 & 1.9 & 13.4 & 4.6 & 16.5 \\
\hline DECS-12 & 1-methyl. & $b$ & 39.1 & 1.9 & 16.2 & 6.6 & 14.4 \\
\hline DECS-12 & 1-methyl. & average & 37.8 & 1.9 & 14.8 & 5.6 & 15.5 \\
\hline DECS-24 & tetralin & $a$ & 62.6 & 6.8 & 33.6 & 9.0 & 13.2 \\
\hline DECS-24 & tetralin & $b$ & 62.4 & 6.9 & 36.4 & 8.5 & 10.6 \\
\hline DECS-24 & tetralin & average & 62.5 & 6.9 & 35.0 & 8.8 & 11.9 \\
\hline DECS-24 & 1-methyl. & $a$ & 64.1 & 7.2 & 37.1 & 4.5 & 15.3 \\
\hline DECS-24 & 1-methyl. & $b$ & 61.1 & 6.9 & 35.7 & 6.1 & 12.4 \\
\hline DECS-24 & 1-methyl. & average & 62.6 & 7.1 & 36.4 & 5.3 & 13.9 \\
\hline
\end{tabular}


Table 6. continued

\begin{tabular}{|c|c|c|c|c|c|c|c|}
\hline DECS-25 & tetralin & a & 52.8 & 3.6 & 7.7 & 6.7 & 34.8 \\
\hline DECS-25 & tetralin & $b$ & 54.5 & 4.2 & 7.2 & 6.2 & 36.9 \\
\hline DECS-25 & tetralin & average & 53.7 & 3.9 & 7.5 & 6.5 & 35.9 \\
\hline DECS-25 & 1-methyl. & a & 56.1 & 4.5 & 4.8 & 6.2 & 40.6 \\
\hline DECS-25 & 1-methyl. & $b$ & 55.1 & 3.9 & 6.6 & 6.9 & 37.6 \\
\hline DECS-25 & 1-methyl. & average & 55.6 & 4.2 & 5.7 & 6.6 & 39.2 \\
\hline DECS-26 & tetralin & a & 55.0 & 4.9 & 10.7 & 6.9 & 32.5 \\
\hline DECS-26 & tetralin & $b$ & 54.2 & 5.7 & 9.5 & 6.7 & 32.3 \\
\hline DECS-26 & tetralin & average & 54.6 & 5.3 & 10.1 & 6.8 & 32.4 \\
\hline DECS-26 & 1-methyl. & a & 52.6 & 14.9 & 9.8 & 6.8 & 21.1 \\
\hline DECS-26 & 1-methyl. & b & 53.3 & 5.5 & 10.0 & 6.4 & 31.4 \\
\hline DECS-26 & 1-methyl. & average & 53.0 & 10.2 & 9.9 & 6.6 & 26.3 \\
\hline DECS-27 & tetralin & a & 48.9 & 15.5 & 14.7 & 7.2 & 11.5 \\
\hline DECS-27 & tetralin & $b$ & 47.5 & 12.2 & 13.3 & 7.2 & 14.8 \\
\hline DECS-27 & tetralin & average & 48.2 & 13.9 & 14.0 & 7.2 & 13.2 \\
\hline DECS-27 & 1-methyl. & $a$ & 43.0 & 11.5 & 10.0 & 9.5 & 12.1 \\
\hline DECS-27 & 1-methyl. & $b$ & 44.5 & 11.1 & 11.2 & 8.3 & 13.9 \\
\hline DECS-27 & 1-methyl. & average & 43.8 & 11.3 & 10.6 & 8.9 & 13.0 \\
\hline DECS-28 & tetralin & $a^{* *}$ & 42.2 & 10.4 & 15.0 & 6.2 & 10.6 \\
\hline DECS-28 & 1-methyl. & a & 41.1 & 12.4 & 16.5 & 5.5 & 6.7 \\
\hline DECS-28 & 1-methyl. & $b$ & 41.9 & 11.9 & 15.8 & 5.6 & 8.6 \\
\hline DECS-28 & 1-methyl. & average & 41.5 & 12.2 & 16.2 & 5.6 & 7.7 \\
\hline
\end{tabular}

${ }^{* *}$ second run for DECS-28 in tetralin failed. 


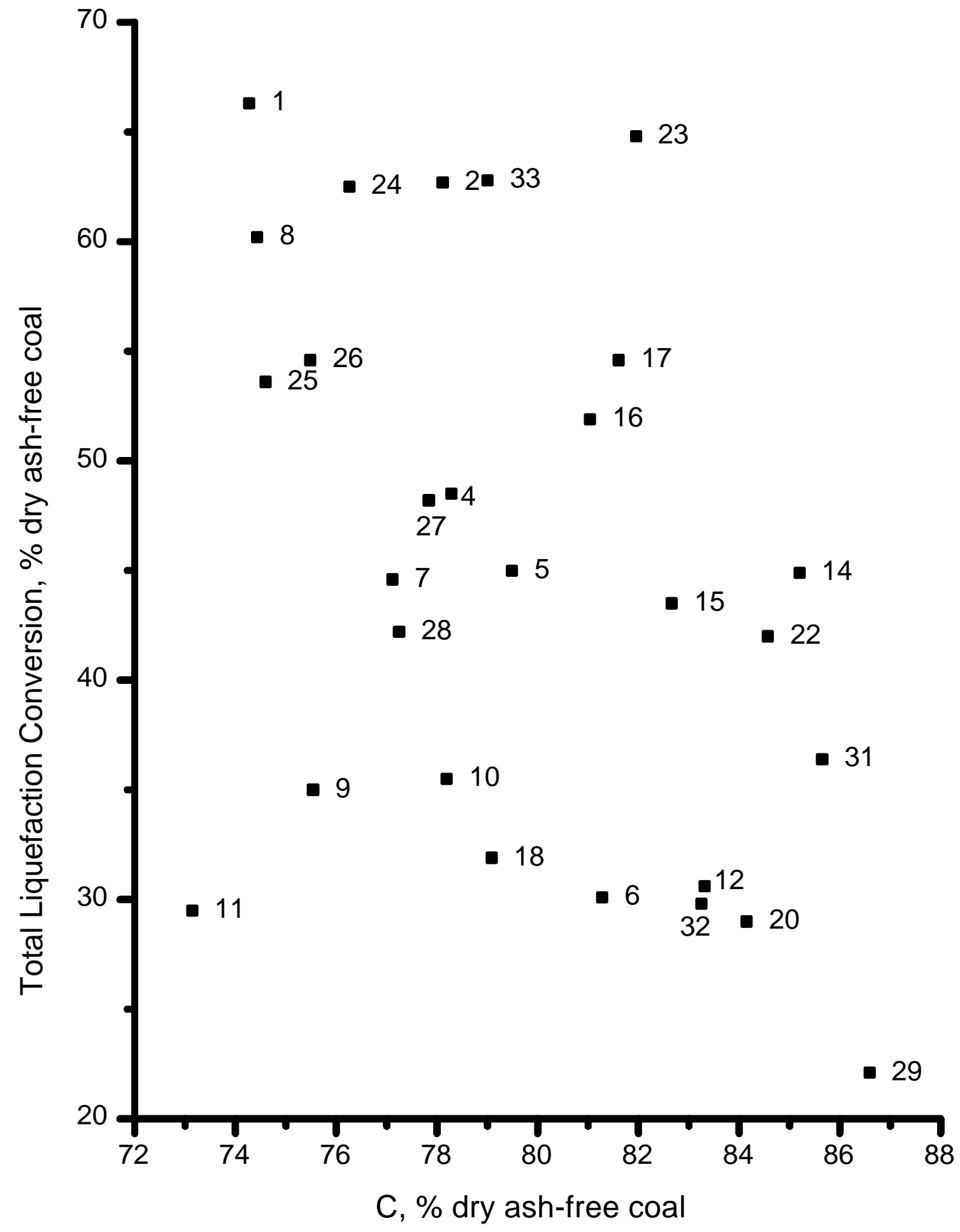

Figure 12. Total liquefaction conversion vs. carbon content, percent of dry ash-free coal; 28 DECS samples subjected to standardized liquefaction test, 1:1 coal:tetralin, $1000 \mathrm{psig}$ $\mathrm{H}_{2}, 350^{\circ} \mathrm{C}, 30$ min (numeric labels are DECS sample numbers). 


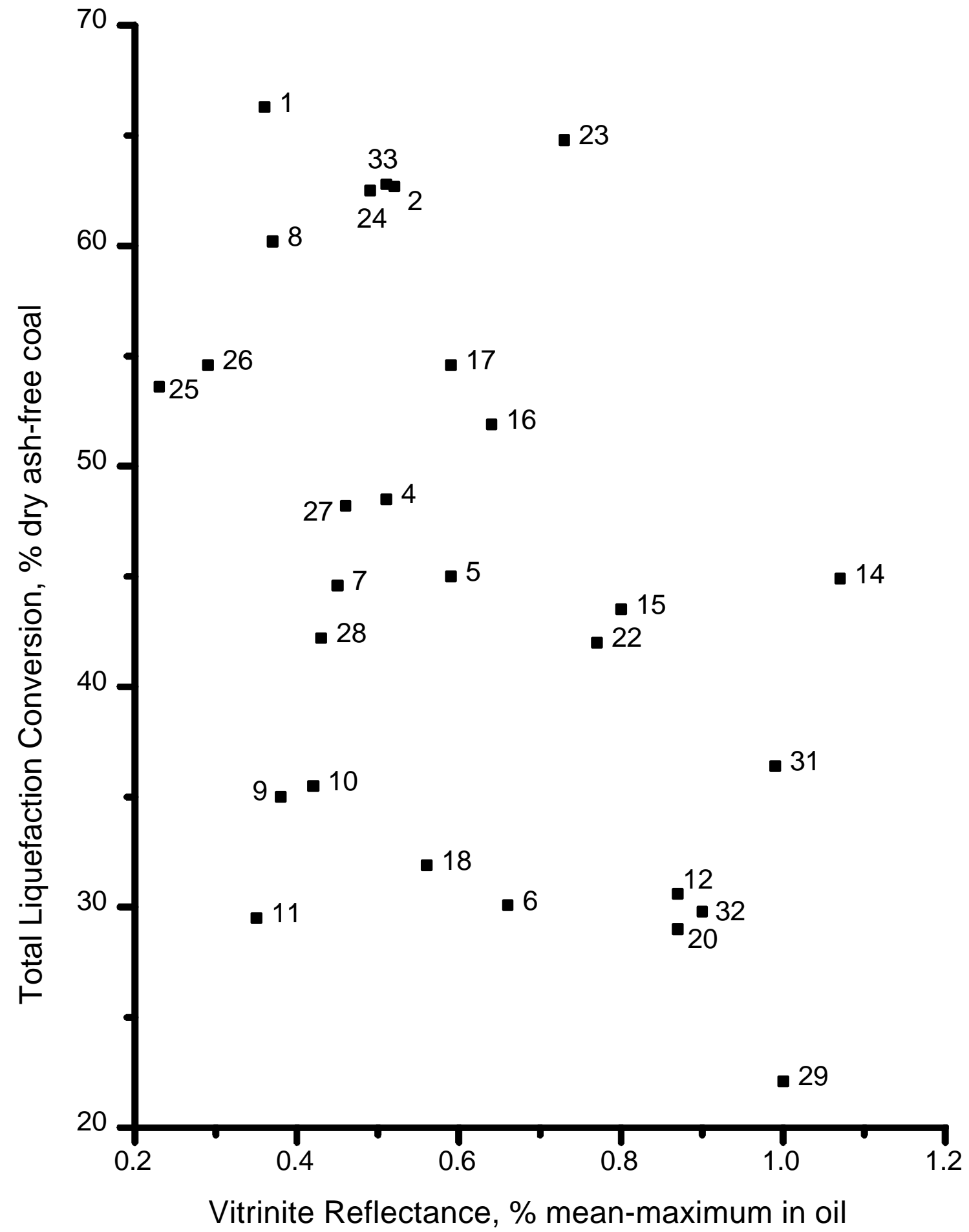

Figure 13. Total liquefaction conversion, percent of dry ash-free coal, vs. vitrinite reflectance; 28 DECS samples subjected to standardized liquefaction test, 1:1 coal:tetralin, 1000 psig $\mathrm{H}_{2}, 350^{\circ} \mathrm{C}, 30 \mathrm{~min}$ (numeric labels are DECS sample numbers). 


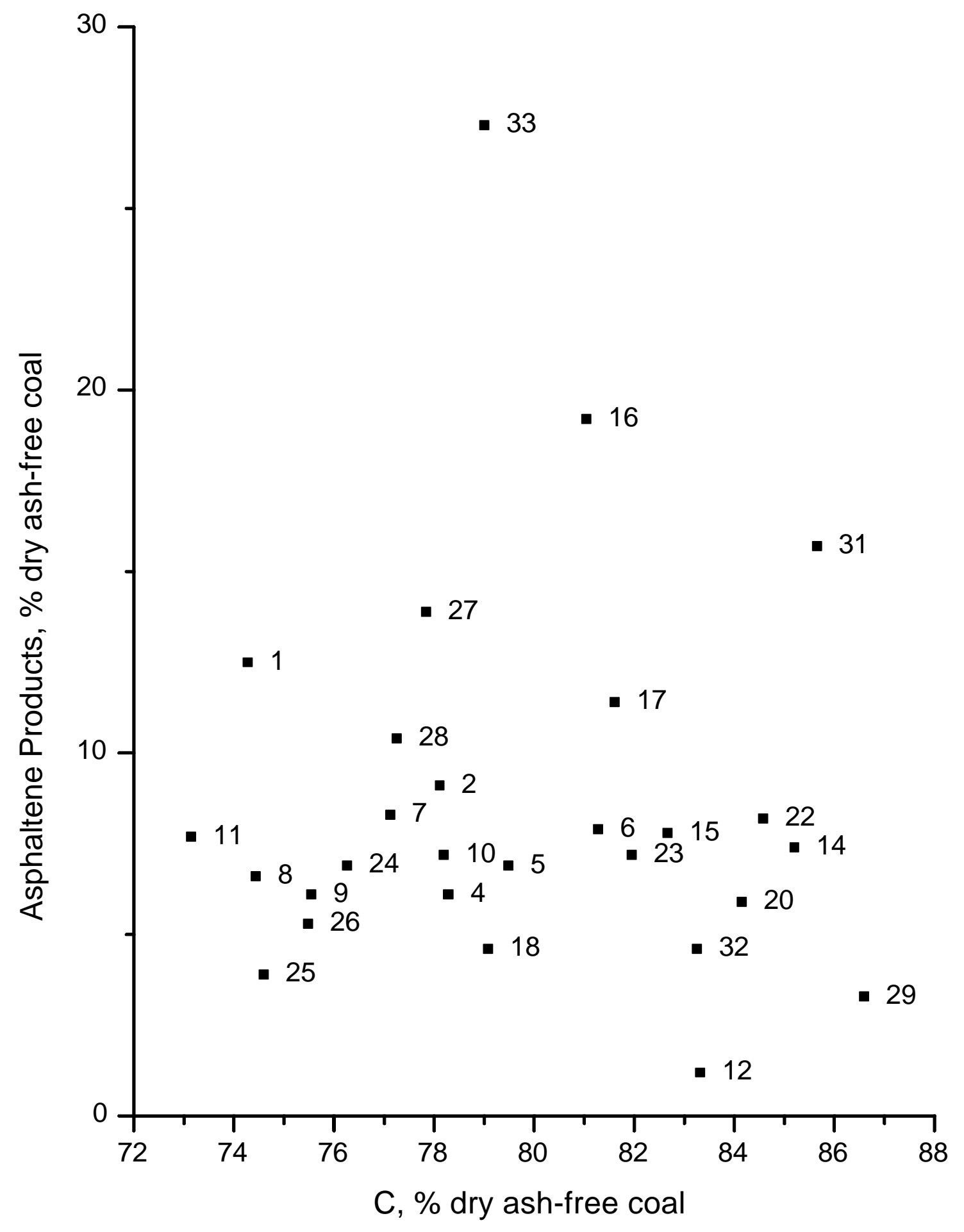

Figure 14. Asphaltene products vs. carbon content, percent of dry ash-free coal; 28 DECS samples subjected to standardized liquefaction test, 1:1 coal:tetralin, $1000 \mathrm{psig}_{2}$, $350^{\circ} \mathrm{C}, 30 \mathrm{~min}$ (numeric labels are DECS sample numbers). 


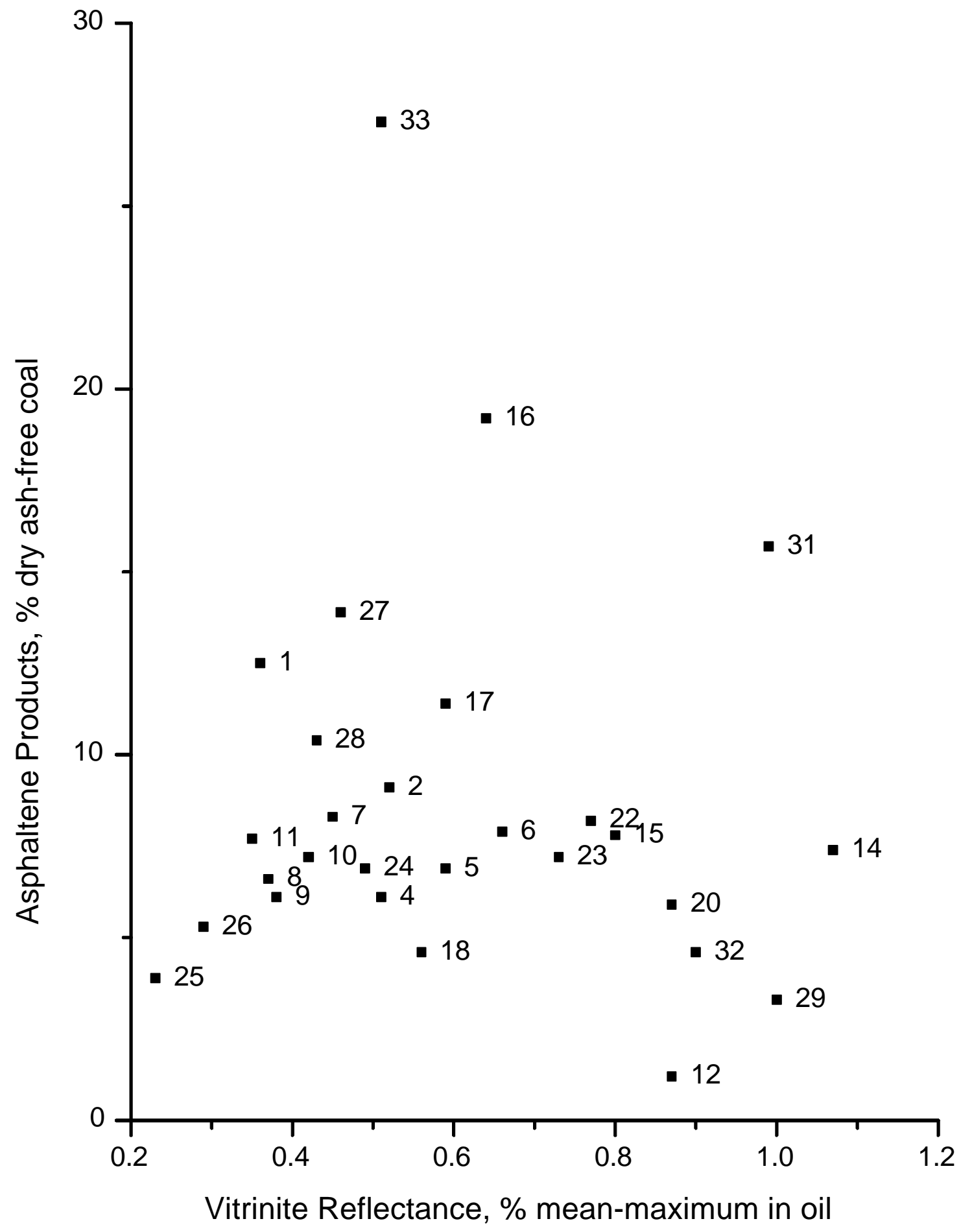

Figure 15. Asphaltene products, percent of dry ash-free coal, vs. vitrinite reflectance; 28 DECS samples subjected to standardized liquefaction test, 1:1 coal:tetralin, $1000 \mathrm{psig}_{2}$, $350^{\circ} \mathrm{C}, 30 \mathrm{~min}$ (numeric labels are DECS sample numbers). 


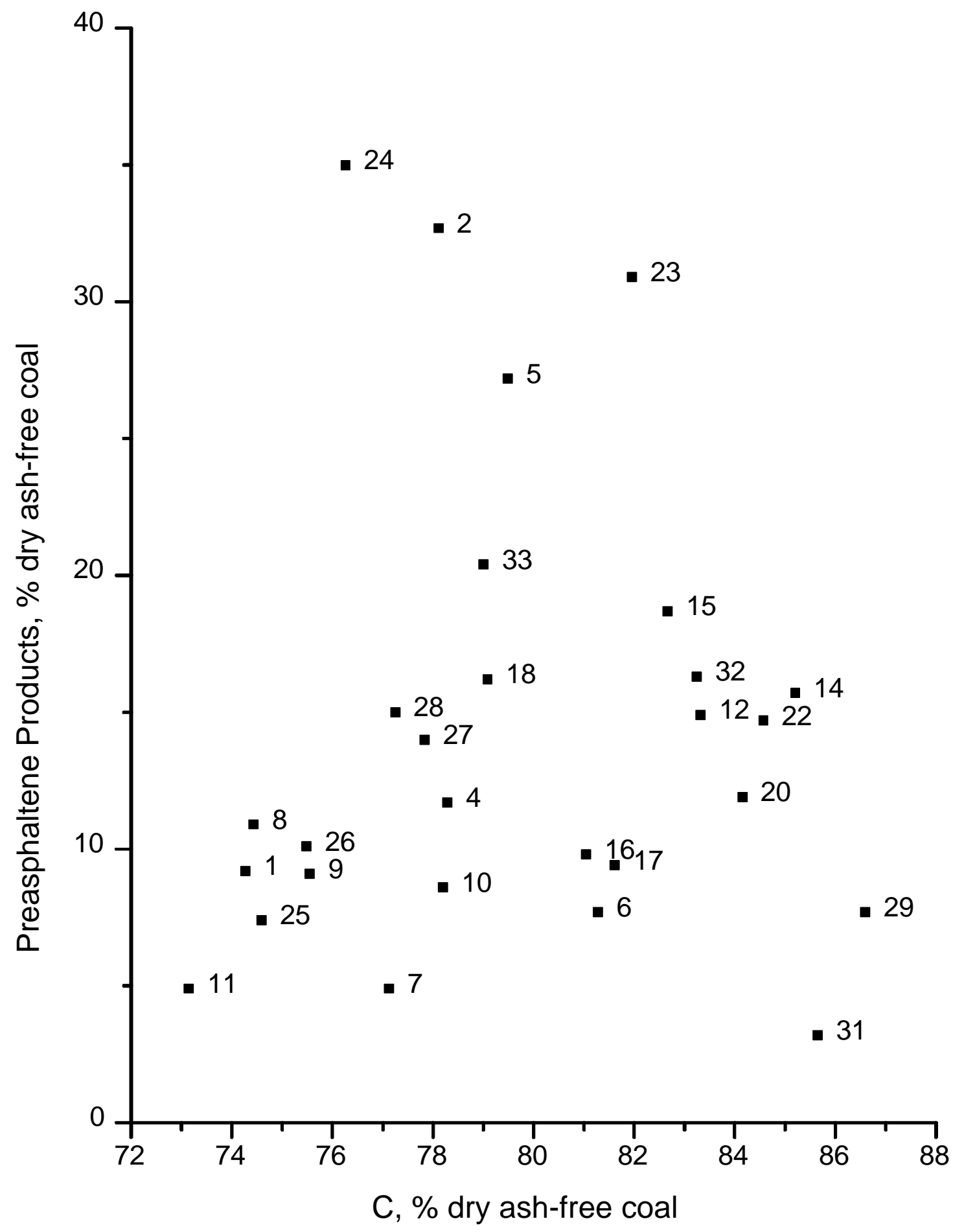

Figure 16. Preasphaltene products vs. carbon content, percent of dry ash-free coal; 28 DECS samples subjected to standardized liquefaction test, 1:1 coal:tetralin, $1000 \mathrm{psig}_{2}$, $350^{\circ} \mathrm{C}, 30 \mathrm{~min}$ (numeric labels are DECS sample numbers). 


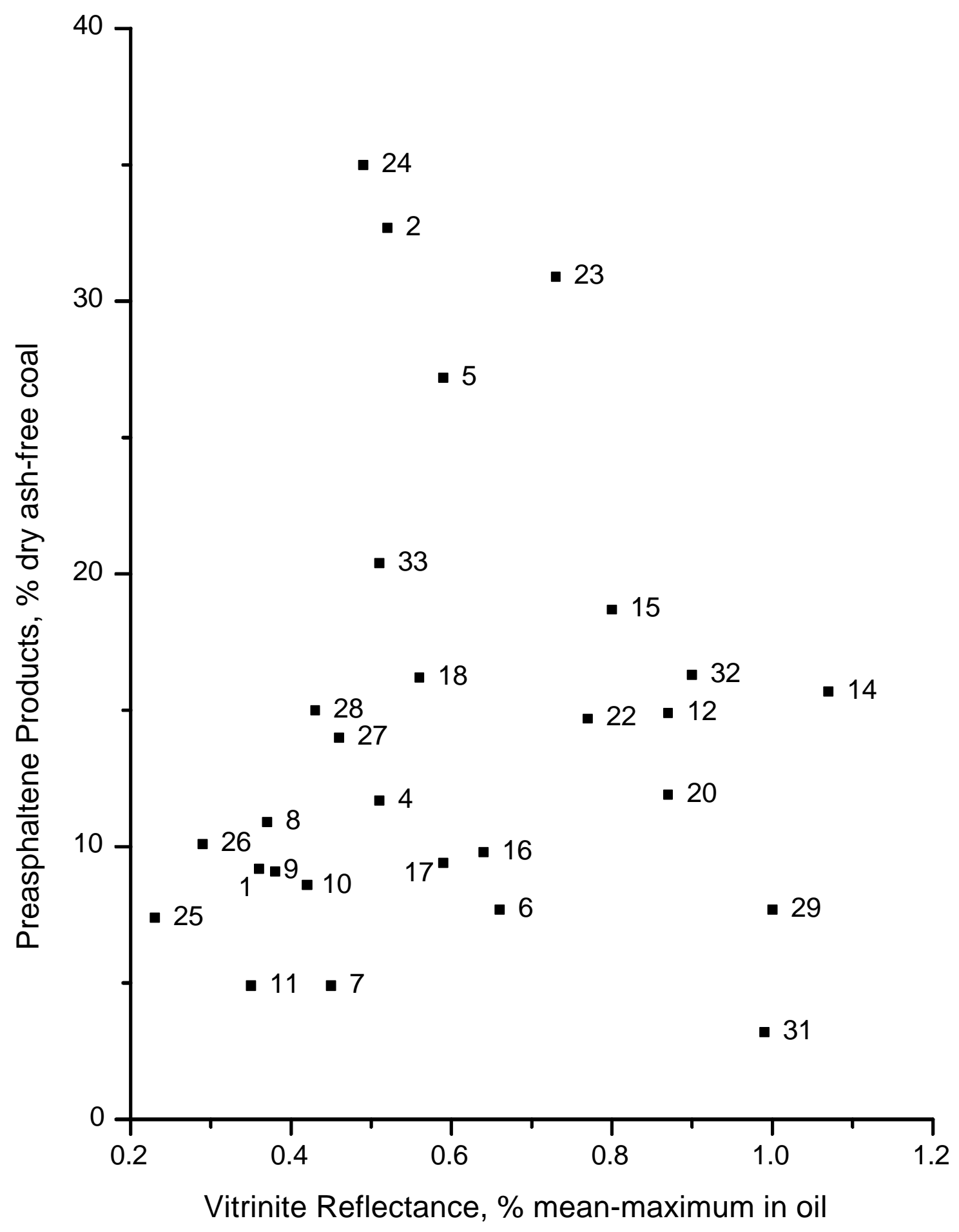

Figure 17. Preasphaltene products, percent of dry ash-free coal, vs. vitrinite reflectance; 28 DECS samples subjected to standardized liquefaction test, 1:1 coal:tetralin, $1000 \mathrm{psig}$ $\mathrm{H}_{2}, 350^{\circ} \mathrm{C}, 30 \mathrm{~min}$ (numeric labels are DECS sample numbers). 


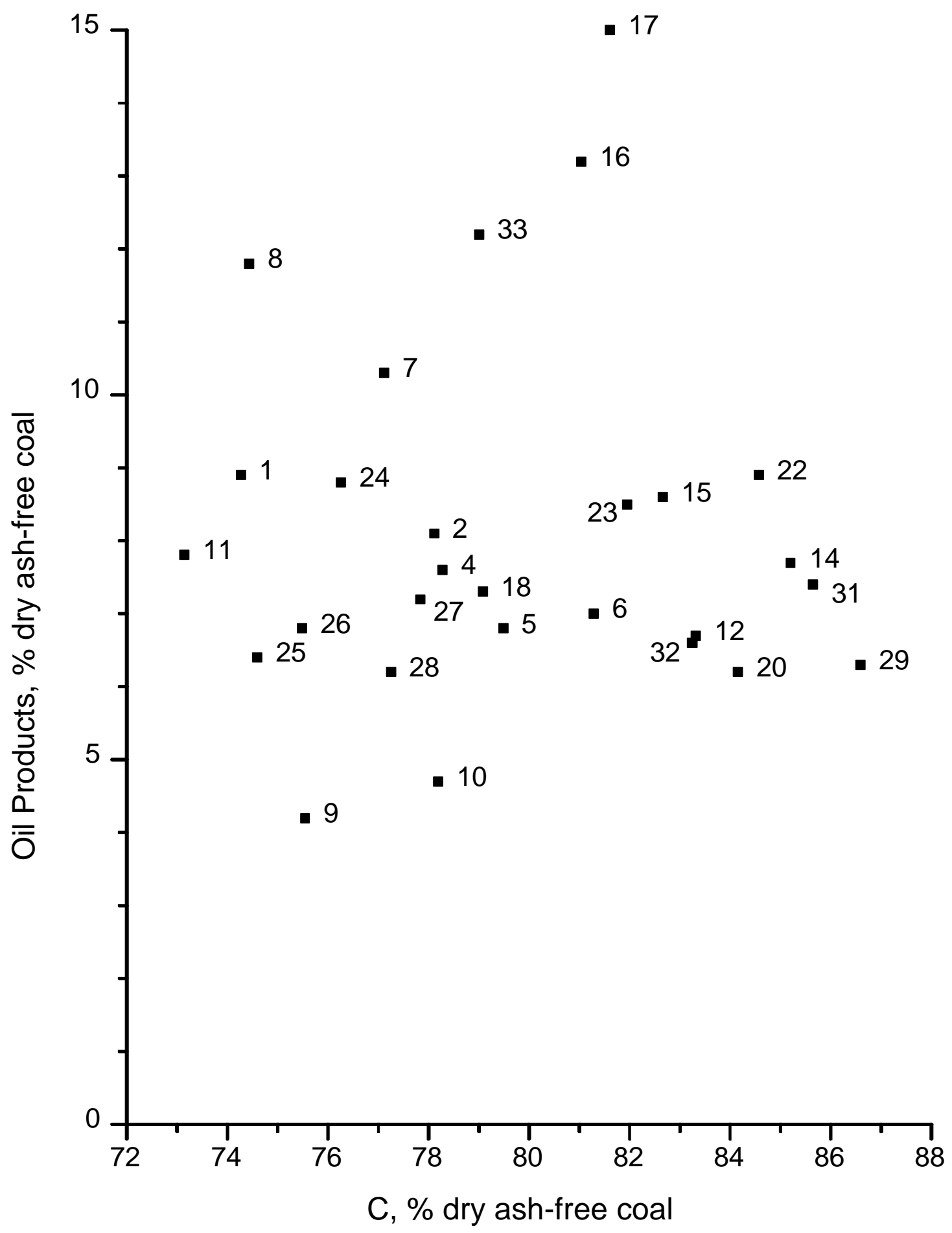

Figure 18. Oil products vs. carbon content, percent of dry ash-free coal; 28 DECS samples subjected to standardized liquefaction test, 1:1 coal:tetralin, $1000 \mathrm{psig}_{2}, 350^{\circ} \mathrm{C}, 30$ min (numeric labels are DECS sample numbers). 


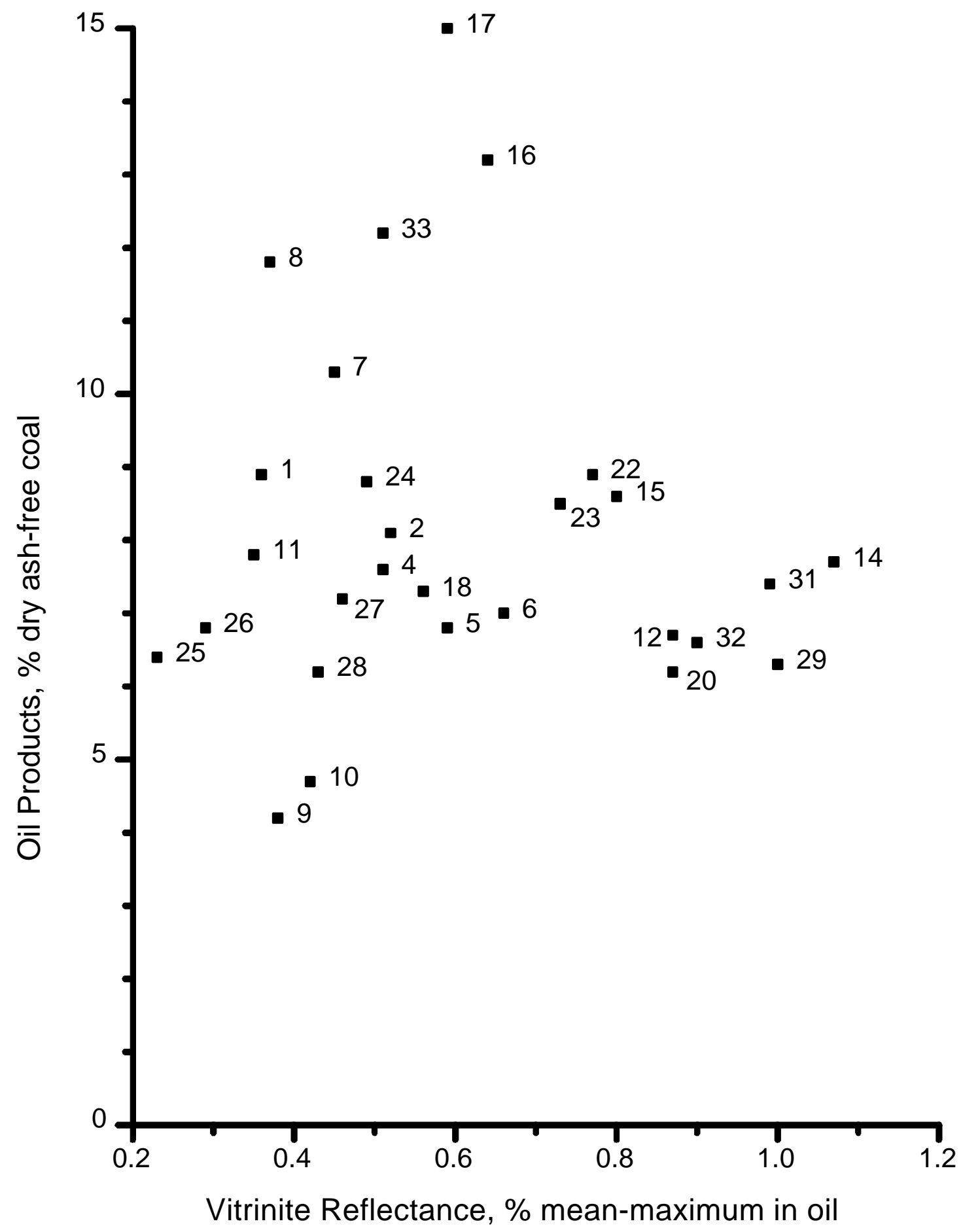

Figure 19. Oil products, percent of dry ash-free coal, vs. vitrinite reflectance; 28 DECS samples subjected to standardized liquefaction test, 1:1 coal:tetralin, $1000 \mathrm{psig}_{2}, 350{ }^{\circ} \mathrm{C}, 30$ min (numeric labels are DECS sample numbers). 


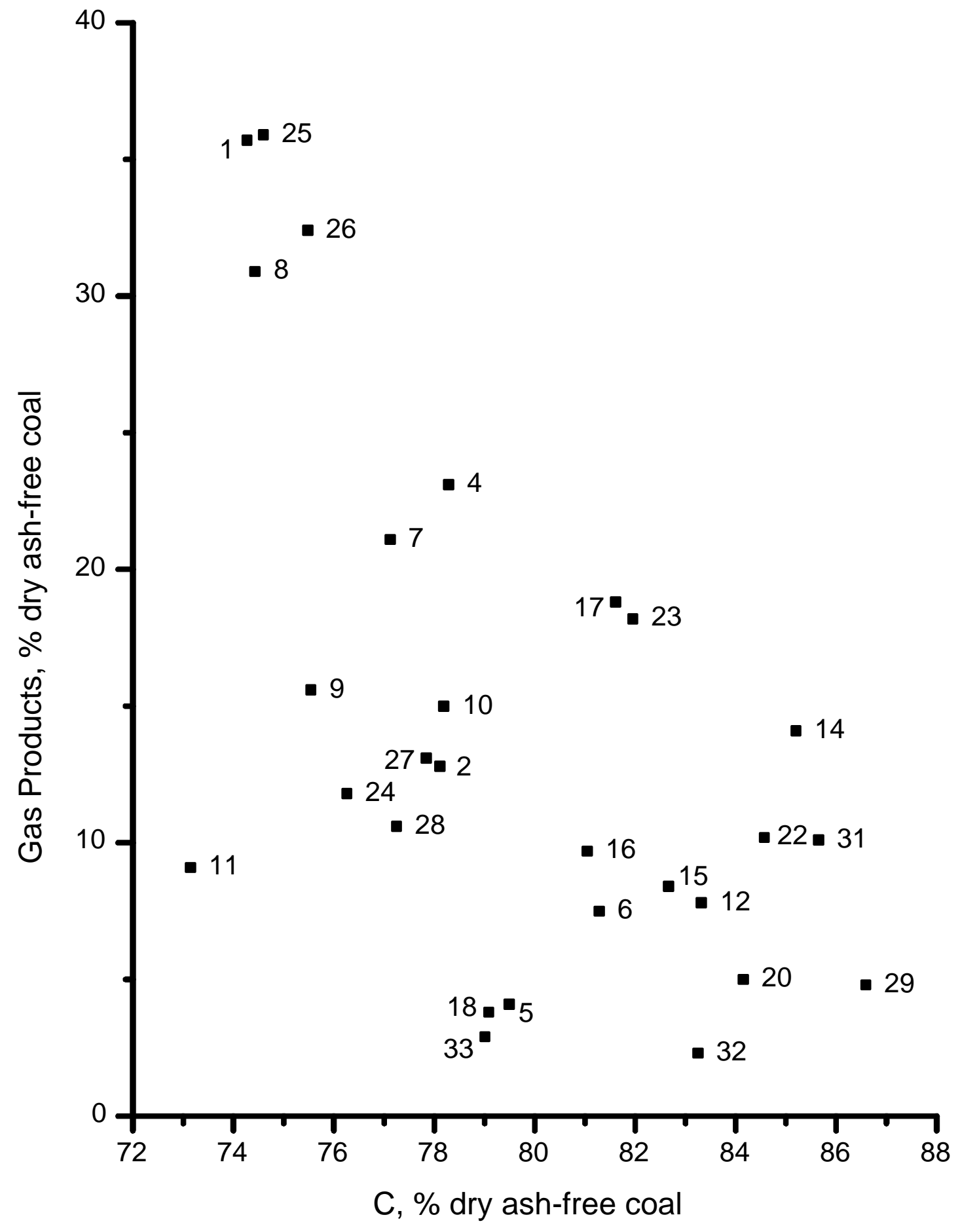

Figure 20. Gas products vs. carbon content, percent of dry ash-free coal; 28 DECS samples subjected to standardized liquefaction test, $1: 1$ coal:tetralin, $1000 \mathrm{psig}_{2}, 350^{\circ} \mathrm{C}, 30$ min (numeric labels are DECS sample numbers). 


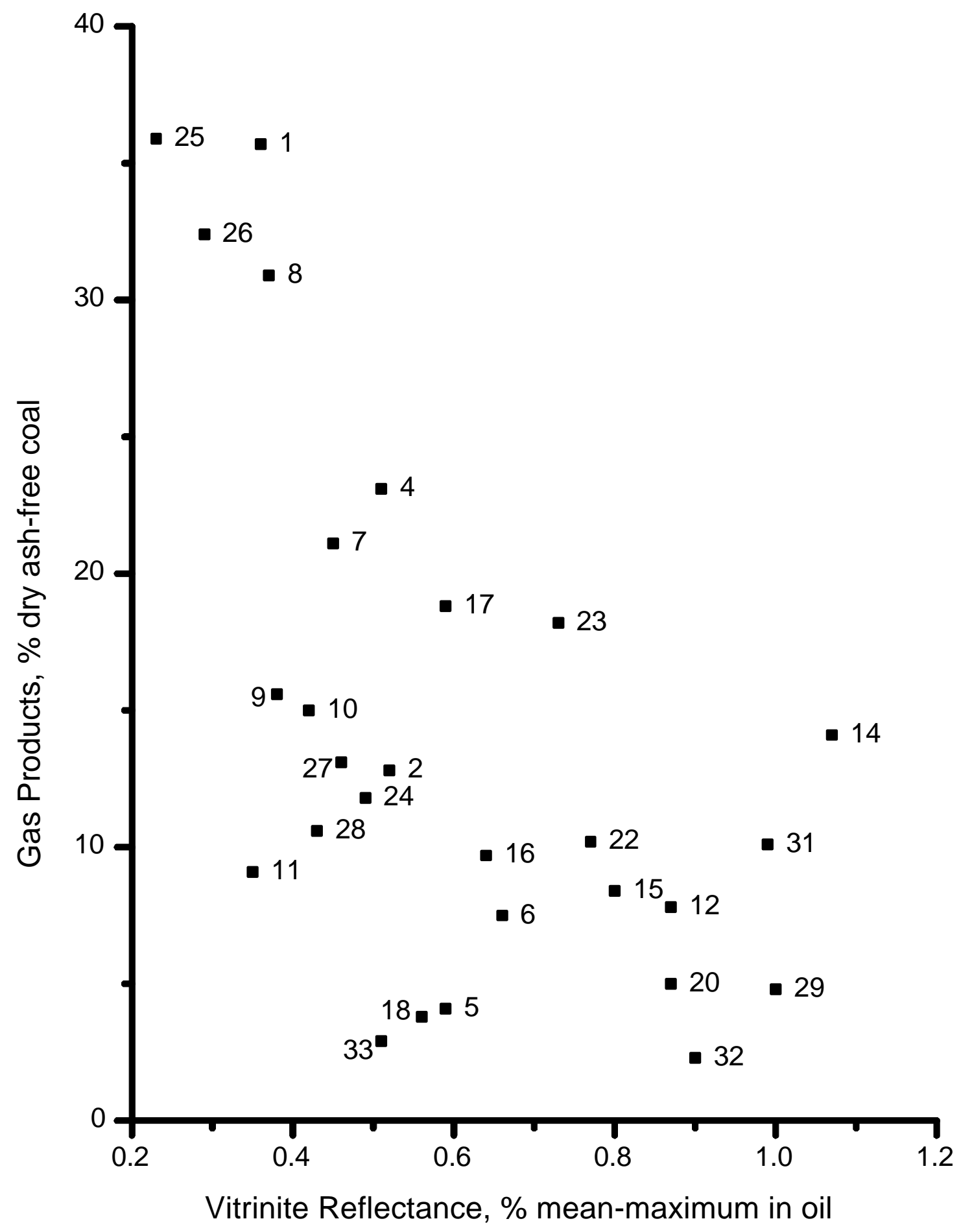

Figure 21. Gas products, percent of dry ash-free coal, vs. vitrinite reflectance; 28 DECS samples subjected to standardized liquefaction test, $1: 1$ coal:tetralin, $1000 \mathrm{psig}_{2}, 350^{\circ} \mathrm{C}, 30$ min (numeric labels are DECS sample numbers). 


\section{Task 1G. Investigation of Changes in Surface Chemistry During Storage}

The general objective of this task was to measure the changes in functional group concentration as a function of duration and type of storage method using reflectance-mode FT-i.r. and direct oxygen determination using electron optical techniques. Also, microscopic measurements of fluorescence alteration and intensity were to be employed to determine the extent of surface alteration during coal storage.

The Pittsburgh seam (see Task 1D) was selected as one of 8 coals to be studied under this task and a general procedure was established for sample processing. It was decided that both vitrinite concentrates and bulk samples from eight fresh bituminous coals would be used in the experimental program. Vitrain bands would be handpicked in a nitrogen-filled glovebox in an attempt to limit their exposure to atmospheric oxygen, to drastic changes in temperature and relative humidity, and exposure to direct sunlight. From these samples, base levels of near-surface oxygen chemistry and concentration would be obtained to compare with measurements of fluorescence intensity and alteration. Subsamples of each bulk coal would be stored under argon in foil bags and matching subsamples would be exposed to the atmosphere. Using the same analytical procedures, these samples would be tested for changes in surface chemistry following two periods of storage (4-6 months and 12 months).

A vitrinite concentrate was prepared from the fresh Pittsburgh seam sample (DECS-23). Five $2.0 \mathrm{~g}$ subsamples of the concentrate were prepared and processed in a nitrogen-filled glovebox, where they were sealed in foil laminate bags before being placed in refrigerated storage. Proximate, ultimate and petrographic analyses were completed, showing that the concentrate is 97 volume \% vitrinite. Further base level fluorescence intensity and alteration measurements were completed on both the whole-seam channel and vitrinite concentrate samples. The UMA 300A infrared microscope which was expected to be used for functional group measurement was evaluated using other samples. Coal blocks corresponding to DECS-24 were collected during the third quarter. Further work was suspended in agreement with DOE when funding for the contract was reduced. The work started under this contract was reported in a final report to DOE under Grant No. DE-FG22-93PC93223 (Mitchell and Davis, 1997).

\section{Task 1H. Organic Geochemistry}

Selected DECS coal samples were subjected to a series of organic geochemical tests to provide baseline data for the various coals studied as part of this project. In this Task, solid-state

${ }^{13} \mathrm{C}$ NMR analyses and pyrolysis/gas chromatography/mass spectrometry were performed on 21 samples. This section examines the results and develops explanations for the trends in each data set as a function of coal rank as determined by both dry, ash-free carbon contents and mean-maximum vitrinite reflectance values. 


\section{Nuclear Magnetic Resonance: CPMAS, DDMAS, and Bloch Decay}

Dried powdered samples of coal were placed in the bullet-type rotor of a Chemagnetics, Inc. M-100 NMR spectrometer and analyzed according to the cross-polarization, magic-angle spinning (CPMAS) and dipolar dephasing with magic angle spinning (DDMAS) procedures outlined by Hatcher (1988). Approximately 10,000 transients having a contact time of $1 \mathrm{~ms}$ and a cycle time of $1 \mathrm{~s}$ were acquired in $0.5 \mathrm{~K}$ of data, zero-filled to $4 \mathrm{~K}$. The chemical shifts were referenced to hexamethylbenzene. For DDMAS, approximately 8000 transients with a cycle time of $1 \mathrm{~s}$ were used at each of 10 dephasing times.

Bloch decay experiments were performed as described by Hatcher et al. (1992), principally to verify the spectra obtained by conventional CPMAS. Approximately 2500 transients with a cycle time of $80 \mathrm{~s}$ were collected.

\section{Results}

Solid-state 13C NMR data for the DECS coals examined in this report are listed in Table 7 , and Table 8 shows the dipolar dephasing data for each coal sample. Figures 22-63 show the sets of individual NMR spectra obtained first (in odd numbered figures) by the technique of cross polarization with magic-angle spinning (CPMAS) and then (in even numbered figures) by simple Bloch decay with magic angle-spinning. While the data for Bloch decay spectra suffer from poor signal-to-noise, the carbon aromaticities calculated for most samples match within 10-15\% of that calculated by the CPMAS method. Because the spectral quality for the CPMAS data are so much better than those of the Bloch decay NMR spectra, only the CPMAS data will be discussed here. Thus, from the spectra, data for carbon aromaticities, aromatic + carbonyl + carboxyl relative to total carbon, phenolic/total carbon, carboxyl + carbonyl/total carbon, and oxygenated aliphatic carbons/total carbons are calculated (Table 7). Dipolar dephasing provides a measure of the protonated aromatic contents and the proportions of methyl and quaternary carbons as a proportion of the aliphatic carbons (Table 8).

Plots of carbon aromaticity with rank parameters (Figures 64 and 65) show excellent and expected trends. DECS-1 and DECS-17 deviate significantly from the trend. This can be explained by the fact that the former is a more sapropelic coal with high liptinite content and the latter is a resin-rich coal. The liptinitic maceral content of these coals lowers the aromaticity due to the fact that the liptinites are generally aliphatic-rich. The other parameters measured from NMR data also show general correlations with rank (Figures 67-73), with DECS-1 and DECS-17 being deviants in most correlations. Perhaps the most interesting parameter, phenolics/total carbon, shows a decreasing trend with rank, except for DECS-1. This sample showed the highest liquefaction yield for low-rank coals, due largely to the fact that the reduced phenolic content limited retrogressive reactions. The DECS-11 sample, however, showed higher phenolic contents and attendantly low liquefaction yields. 
Plots of protonated aromatic carbons, a measure of the degree of aromatic ring condensation, and methyl/quaternary carbons with rank show absolutely no correlation (Figures 74-77). This could be due to the large variations in macerals which give rise to changes in these parameters.

Table 7. Structural parameters of DECS coals determined by CPMAS measurements

\begin{tabular}{|c|c|c|c|c|c|c|c|c|}
\hline \multicolumn{4}{|c|}{ sample } & \multirow[b]{2}{*}{$\begin{array}{l}\text { carbon } \\
\text { aromaticity }\end{array}$} & \multirow{2}{*}{$\begin{array}{l}\text { (aromatic + } \\
\text { carbonyl + } \\
\text { carboxyl) / } \\
\text { total } \\
\text { carbons }\end{array}$} & \multirow{2}{*}{$\begin{array}{l}\text { phenolics/ } \\
\text { total } \\
\text { carbons }\end{array}$} & \multirow{2}{*}{$\begin{array}{l}\text { (carboxyl+ } \\
\text { carbonyl)/ } \\
\text { total } \\
\text { carbons }\end{array}$} & \multirow{2}{*}{$\begin{array}{l}\text { oxygenated } \\
\text { aliphatic } \\
\text { carbons / } \\
\text { total } \\
\text { carbons }\end{array}$} \\
\hline DECS- & seam & rank & St & & & & & \\
\hline 1 & Bottom & subC & $\overline{\mathrm{TX}}$ & 0.45 & 0.52 & 0.14 & 0.07 & 0.050 \\
\hline 2 & Illinois \#6 & $\mathrm{hvCb}$ & IL & 0.64 & 0.73 & 0.19 & 0.09 & 0.040 \\
\hline 8 & Smith-Roland & subC & WY & 0.51 & 0.62 & 0.21 & 0.11 & 0.050 \\
\hline 9 & Dietz & subB & MT & 0.59 & 0.68 & 0.20 & 0.09 & 0.030 \\
\hline 11 & Beulah & $\operatorname{lig} A$ & ND & 0.60 & 0.71 & 0.20 & 0.11 & 0.020 \\
\hline 12 & Pittsburgh & hvAb & PA & 0.69 & 0.76 & 0.16 & 0.07 & 0.023 \\
\hline 13 & Sewell & $\mathrm{mvb}$ & WV & 0.79 & 0.80 & 0.14 & 0.01 & 0.010 \\
\hline 17 & Blind Canyon & hvAb & UT & 0.54 & 0.60 & 0.18 & 0.06 & 0.040 \\
\hline 18 & Kentucky \#9 & hvBb & KY & 0.63 & 0.66 & 0.15 & 0.03 & 0.020 \\
\hline 19 & Pocahontas \#3 & Ivb & VA & 0.80 & 0.81 & 0.13 & 0.01 & 0.010 \\
\hline 23 & Pittsburgh & hvAb & PA & 0.67 & 0.75 & 0.17 & 0.08 & 0.024 \\
\hline 24 & Illinois \#6 & $\mathrm{hvCb}$ & IL & 0.65 & 0.72 & 0.20 & 0.07 & 0.017 \\
\hline 25 & Pust & $\operatorname{lig} A$ & MT & 0.60 & 0.72 & 0.21 & 0.12 & 0.037 \\
\hline 26 & Wyodak & subB & WY & 0.56 & 0.68 & 0.20 & 0.12 & 0.022 \\
\hline 27 & Deadman & subA & WY & 0.63 & 0.75 & 0.20 & 0.12 & 0.020 \\
\hline 28 & Green & $\mathrm{hvCb}$ & $\mathrm{AZ}$ & 0.57 & 0.63 & 0.18 & 0.07 & 0.020 \\
\hline 29 & U. Banner \#3 & hvAb & VA & 0.72 & 0.74 & 0.11 & 0.02 & 0.007 \\
\hline 30 & Splash Dam & $\mathrm{mvb}$ & VA & 0.76 & 0.78 & 0.11 & 0.02 & 0.002 \\
\hline 31 & Pond Creek & hvAb & $\mathrm{KY}$ & 0.70 & 0.72 & 0.13 & 0.02 & 0.009 \\
\hline 32 & Stockton-Lew. & hvAb & WV & 0.73 & 0.75 & 0.15 & 0.02 & 0.002 \\
\hline 33 & Ohio \#4A & hvBb & $\mathrm{OH}$ & 0.75 & 0.80 & 0.15 & 0.05 & 0.019 \\
\hline \multicolumn{9}{|c|}{ 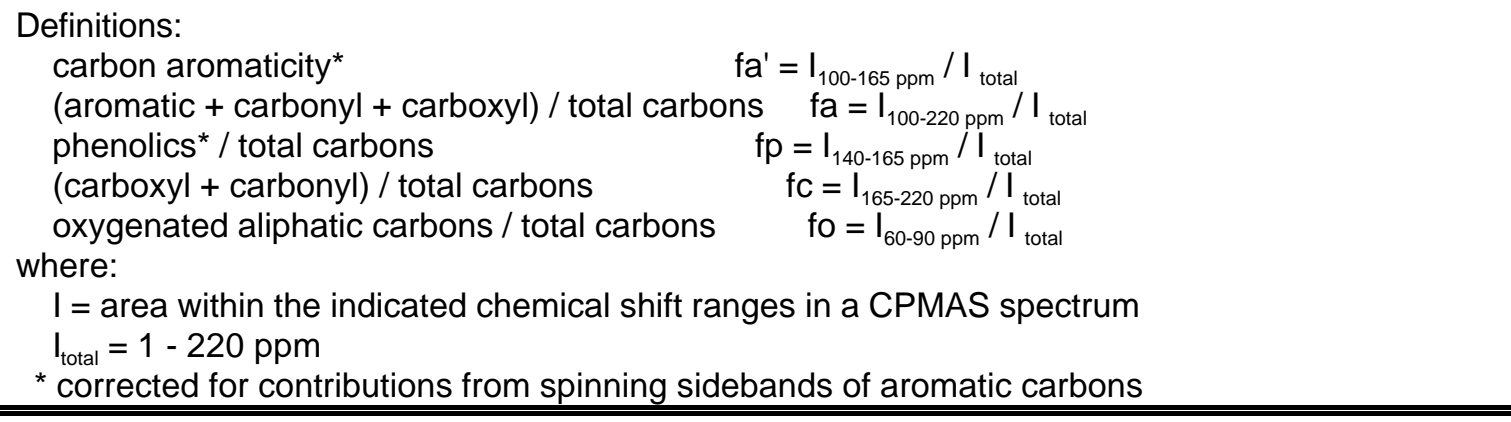 } \\
\hline
\end{tabular}


Table 8. Structural Parameters of DECS coals determined by DDMAS measurements

\begin{tabular}{|c|c|c|c|c|c|}
\hline \multicolumn{4}{|l|}{ sample } & \multirow{2}{*}{$\begin{array}{c}\text { aromatic } \\
\text { protonated C }\end{array}$} & \multirow{2}{*}{$\begin{array}{c}\text { mobile } \mathrm{CH}_{3} \text { and } \\
\text { quaternary } \\
\text { aliphatic } \mathrm{C}\end{array}$} \\
\hline number & seam & rank & St & & \\
\hline DECS-1 & Bottom & subC & TX & 0.30 & 0.15 \\
\hline DECS-2 & Illinois \#6 & $\mathrm{hvCb}$ & IL & 0.55 & 0.48 \\
\hline DECS-8 & Smith-Roland & subC & WY & 0.28 & 0.35 \\
\hline DECS-9 & Dietz & subB & MT & 0.34 & 0.19 \\
\hline DECS-11 & Beulah & $\operatorname{lig} A$ & ND & 0.45 & 0.22 \\
\hline DECS-12 & Pittsburgh & hvAb & PA & 0.49 & 0.29 \\
\hline DECS-13 & Sewell & $m v b$ & WV & 0.37 & 0.19 \\
\hline DECS-17 & Blind Canyon & hvAb & UT & 0.40 & 0.14 \\
\hline DECS-18 & Kentucky \#9 & hvBb & KY & 0.20 & 0.34 \\
\hline DECS-19 & Pocahontas \#3 & Ivb & VA & 0.25 & 0.34 \\
\hline DECS-23 & Pittsburgh & hvAb & PA & 0.39 & 0.58 \\
\hline DECS-24 & Illinois \#6 & $\mathrm{hvCb}$ & IL & 0.15 & 0.39 \\
\hline DECS-25 & Pust & $\operatorname{lig} A$ & MT & 0.43 & 0.14 \\
\hline DECS-26 & Wyodak & subB & WY & 0.56 & 0.15 \\
\hline DECS-27 & Deadman & subA & WY & 0.37 & 0.16 \\
\hline DECS-28 & Green & $\mathrm{hvCb}$ & $A Z$ & 0.25 & 0.35 \\
\hline DECS-29 & Upper Banner \#3 & $h v A b$ & VA & 0.29 & 0.49 \\
\hline DECS-30 & Splash Dam & $m v b$ & VA & 0.21 & 0.72 \\
\hline DECS-31 & Pond Creek & hvAb & KY & 0.27 & 0.25 \\
\hline DECS-32 & Stockton-Lewiston & $h v A b$ & WV & 0.19 & 0.53 \\
\hline DECS-33 & Ohio \#4A & hvBb & $\mathrm{OH}$ & 0.17 & 0.65 \\
\hline
\end{tabular}




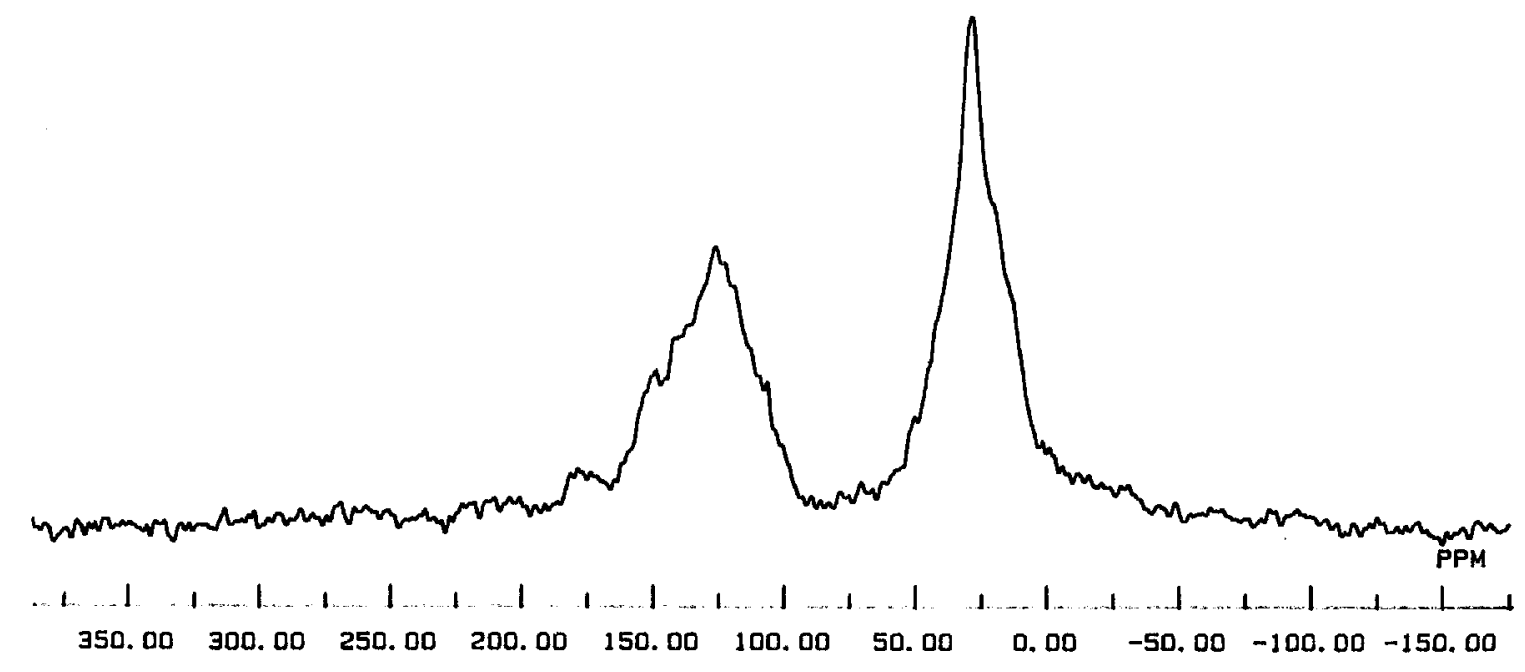

Figure 22. CPMAS NMR spectrum of DECS-1, subC Bottom seam, TX.

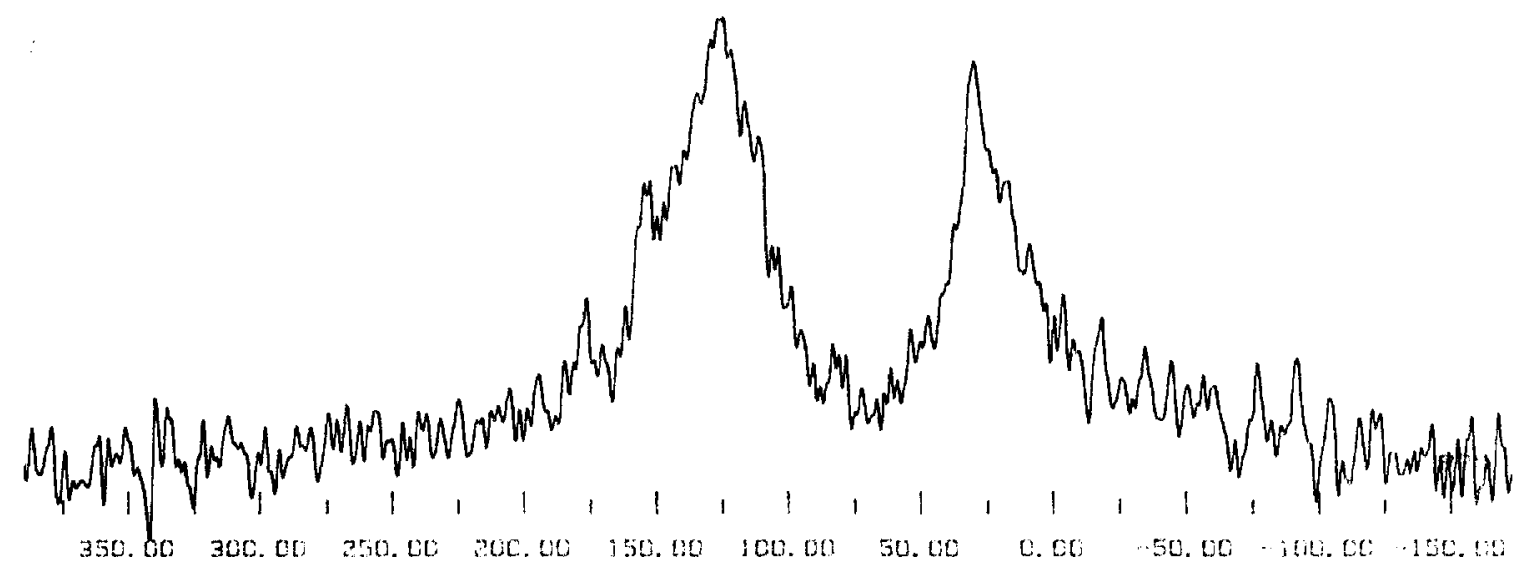

Figure 23. Bloch decay NMR spectrum of DECS-1, subC Bottom seam, TX. 


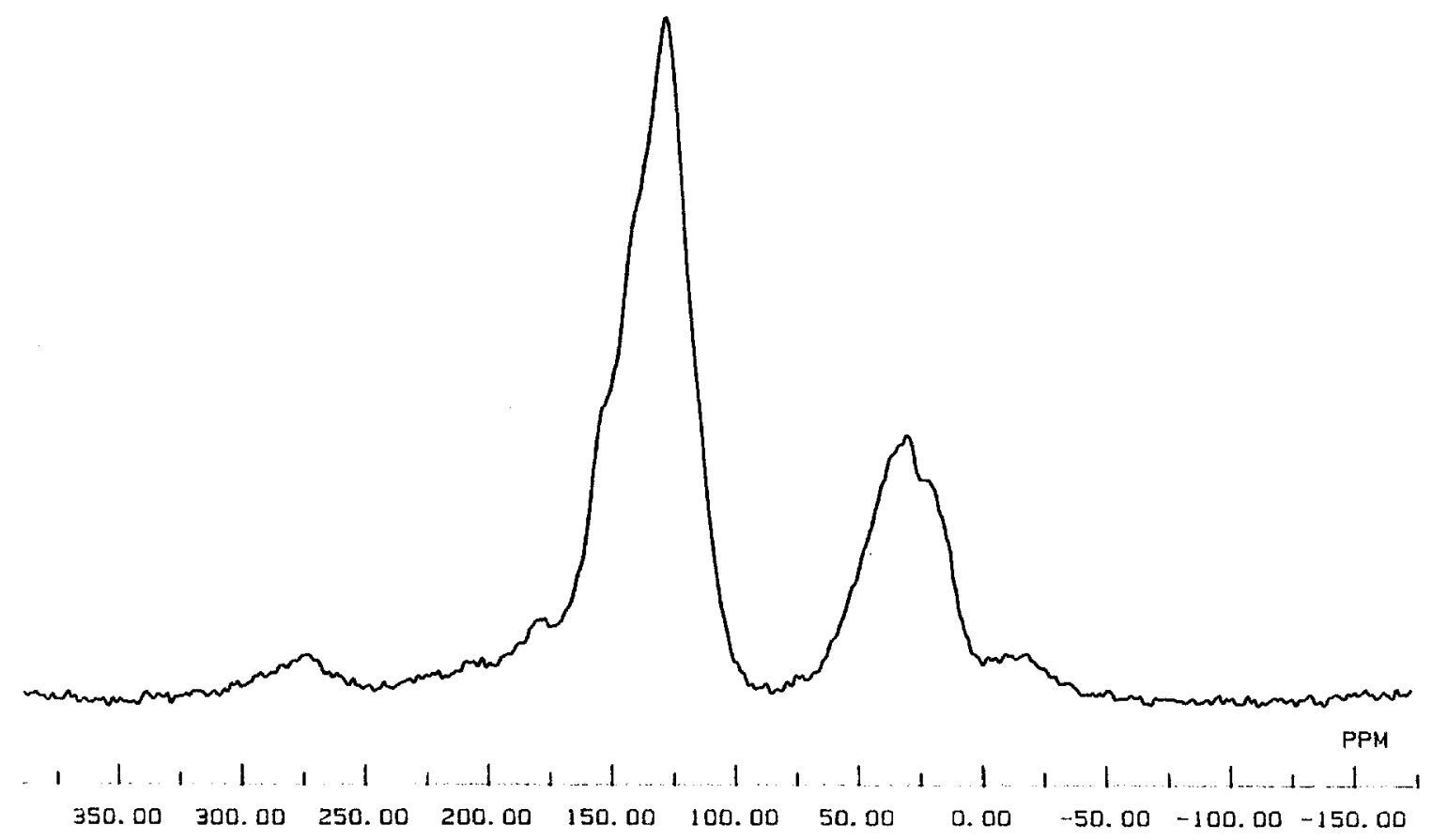

Figure 24. CPMAS NMR spectrum of DECS-2, hvCb Illinois \#6 seam, IL.

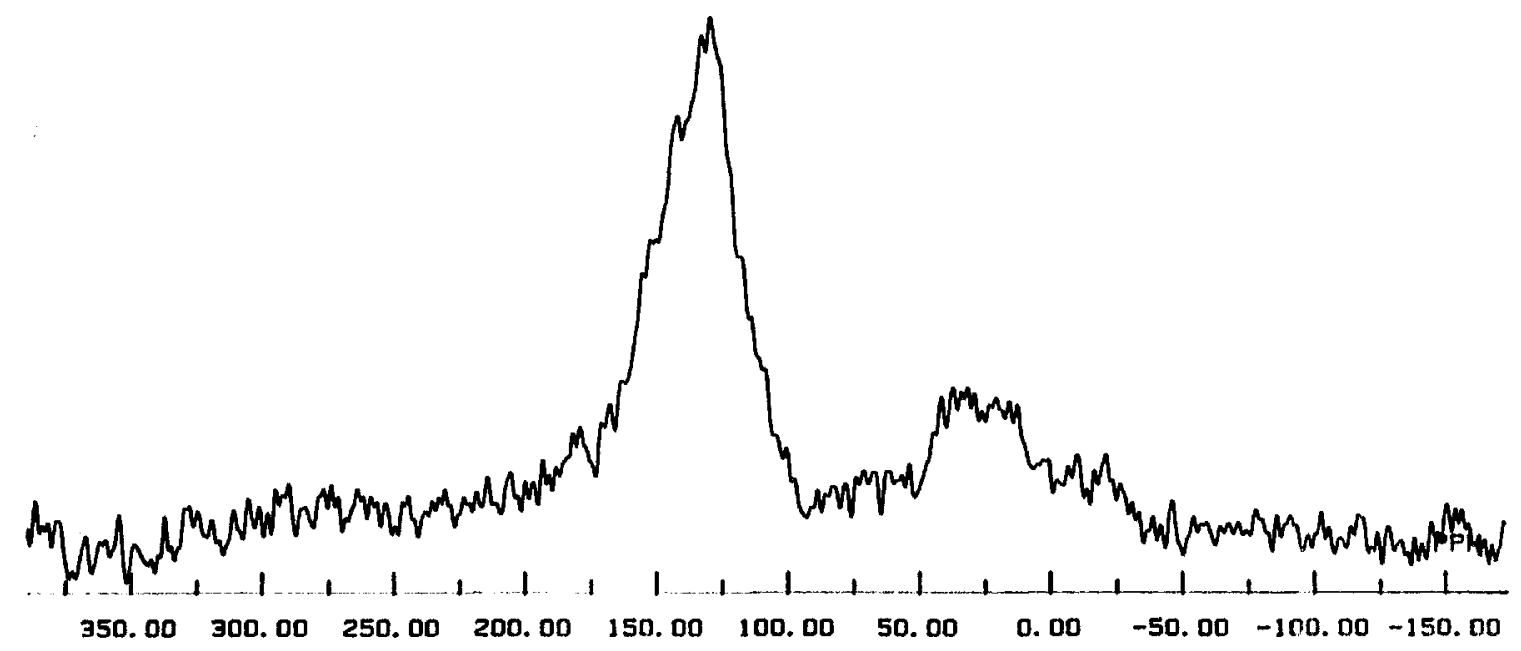

Figure 25. Bloch decay NMR spectrum of DECS-2, hvCb Illinois \#6 seam, IL. 


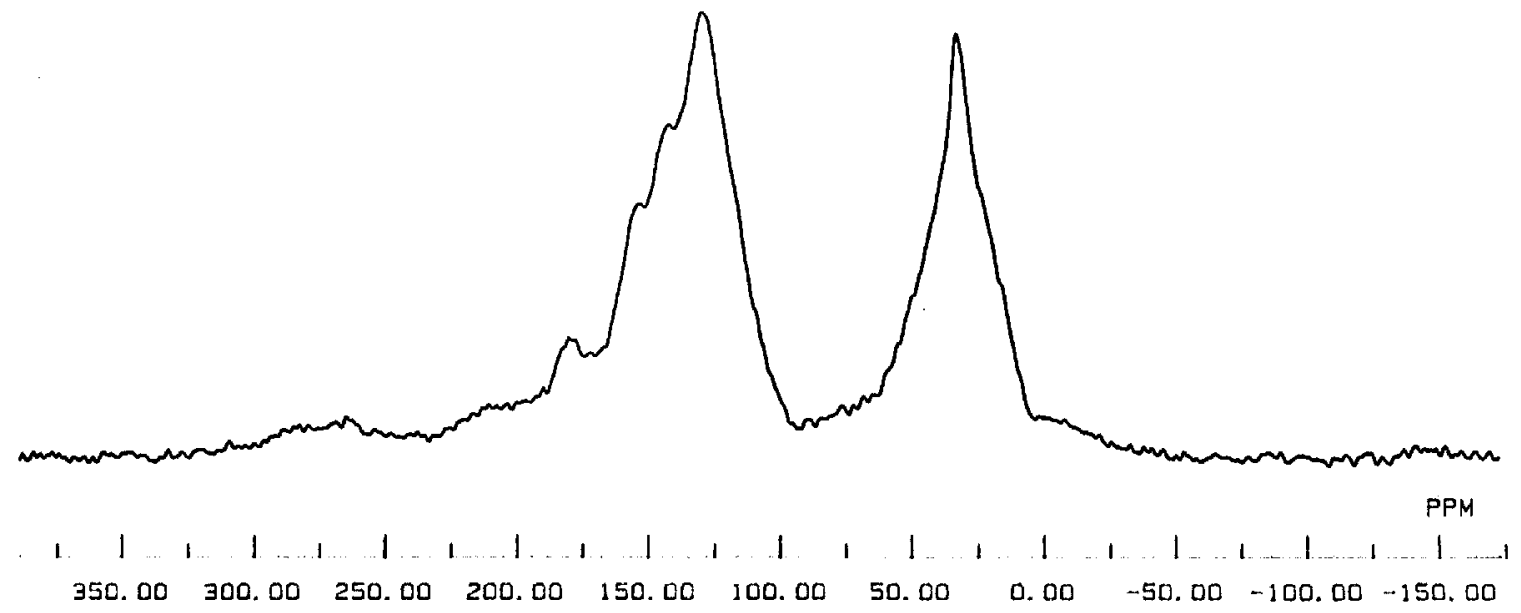

Figure 26. CPMAS NMR spectrum of DECS-8, subC Smith-Roland (“Wyodak”) seam, WY.

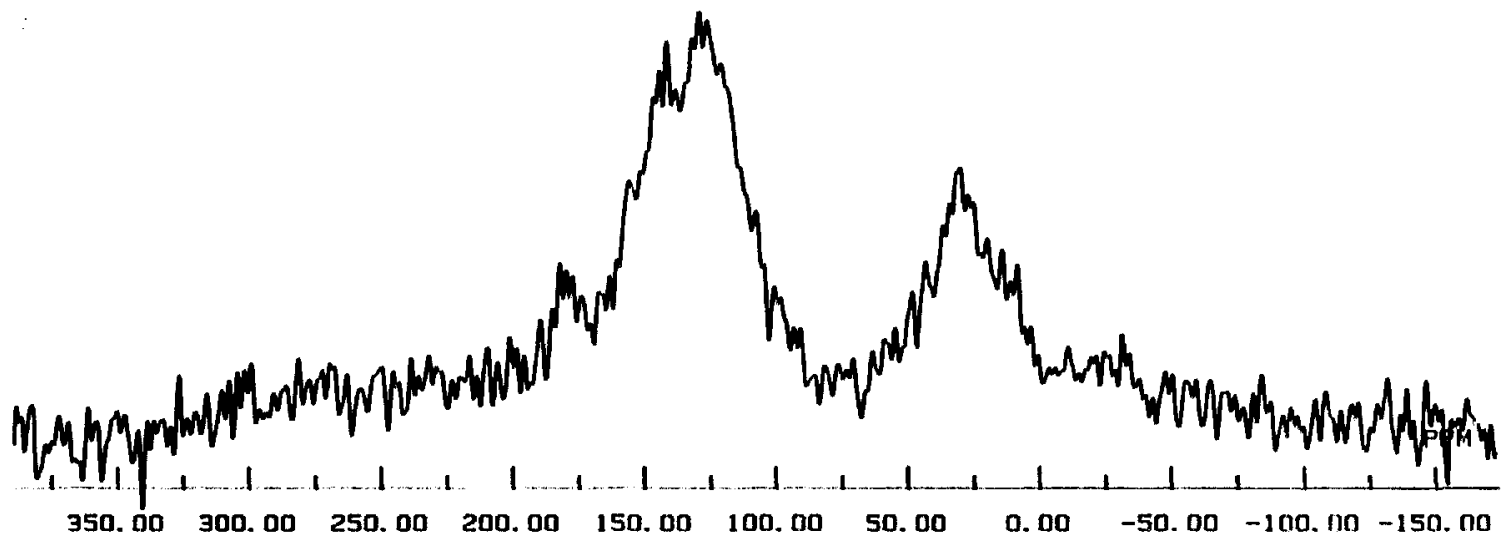

Figure 27. Bloch decay NMR spectrum of DECS-8, subC Smith-Roland ("Wyodak") seam, WY. 


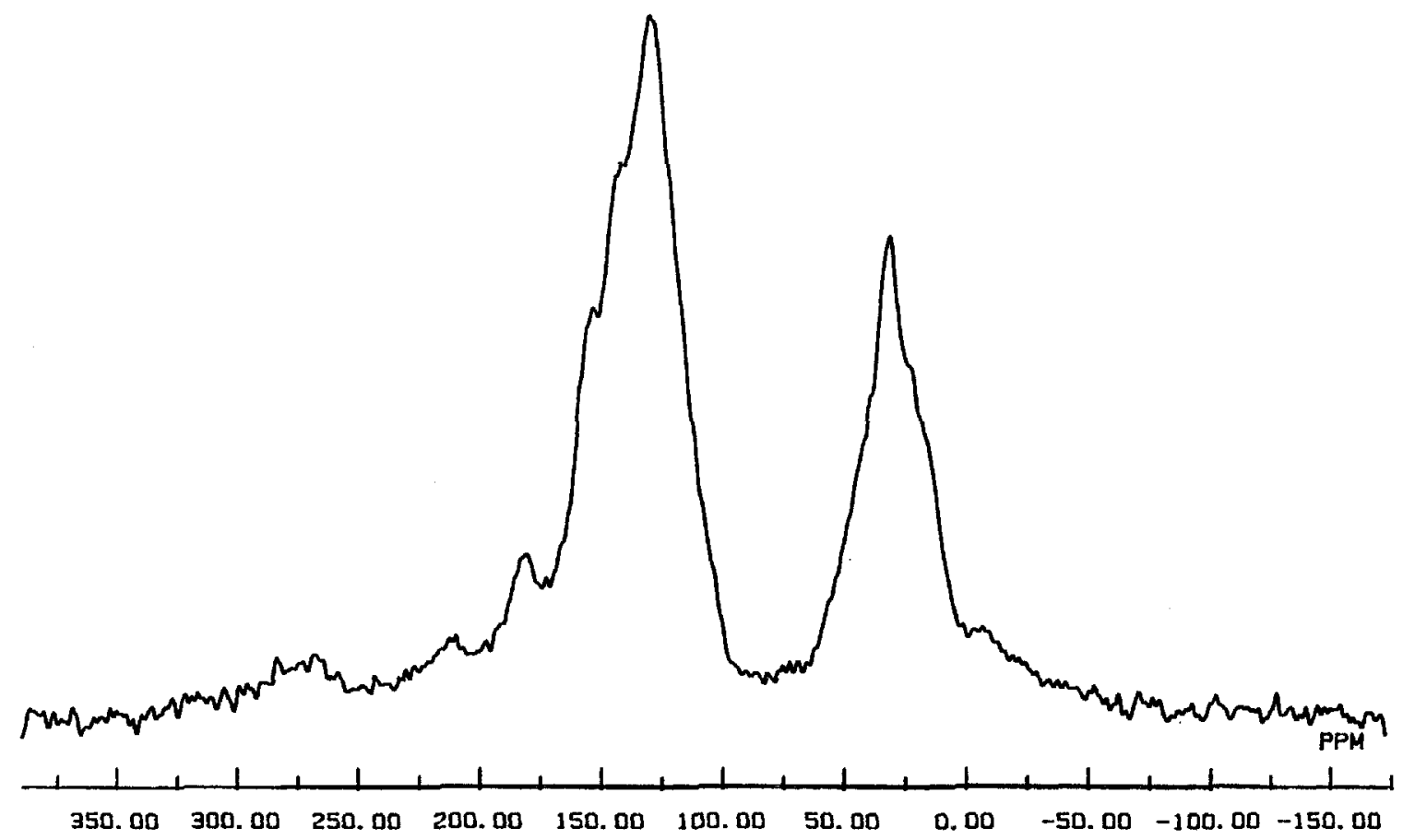

Figure 28. CPMAS NMR spectrum of DECS-9, subB Dietz seam, MT.

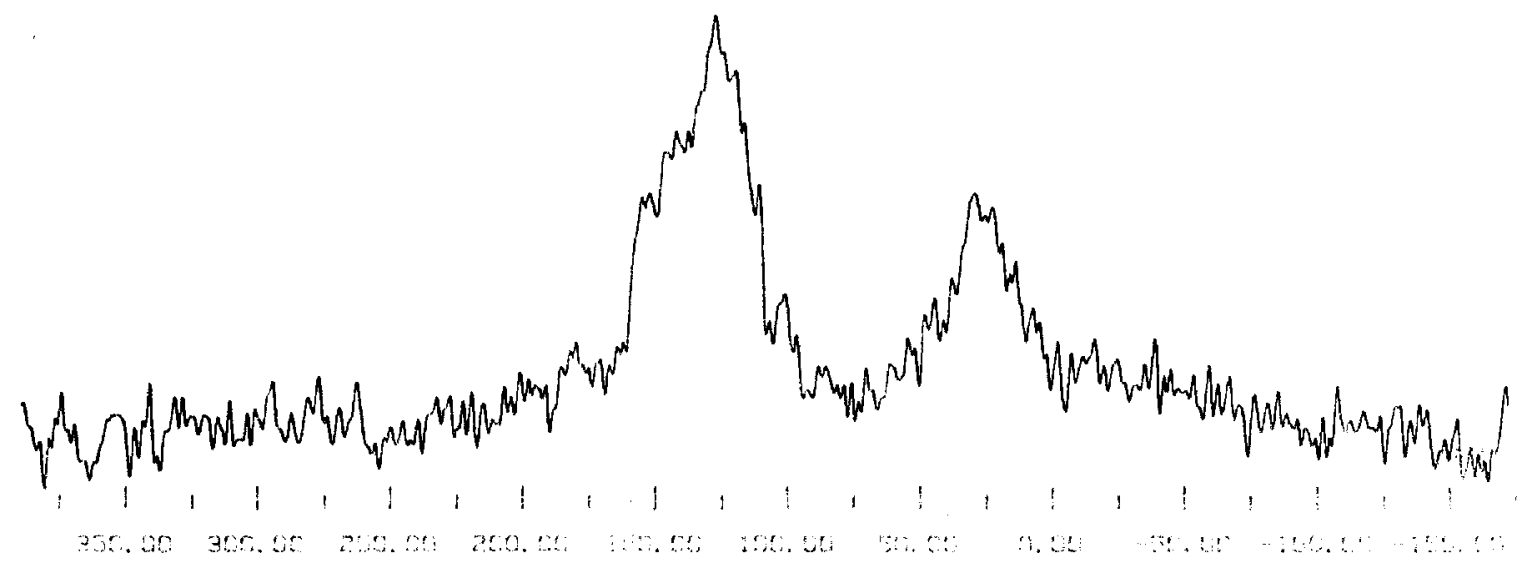

Figure 29. Bloch decay NMR spectrum of DECS-9, subB Dietz seam, MT. 


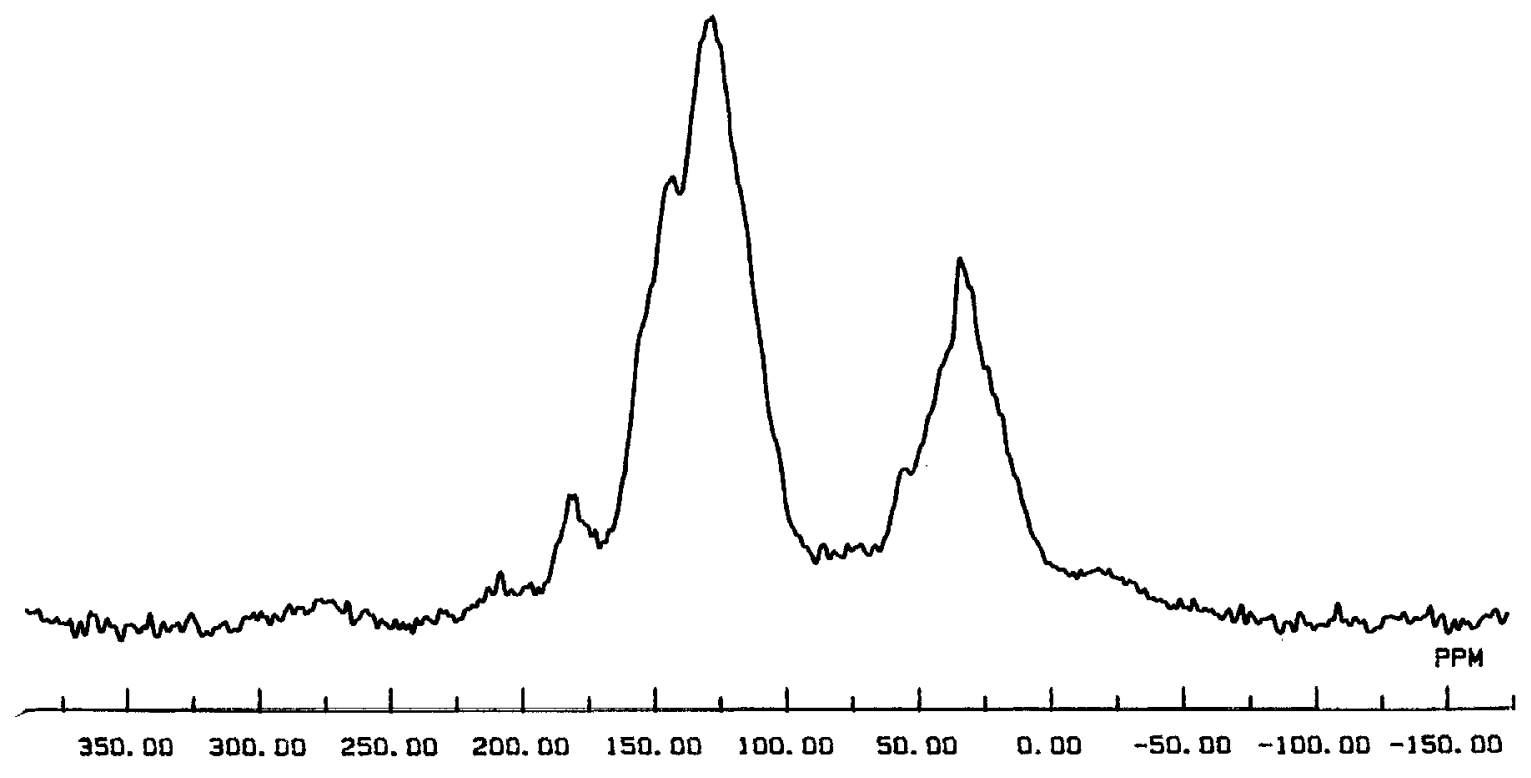

Figure 30. CPMAS NMR spectrum of DECS-11, ligA Beulah seam, ND.

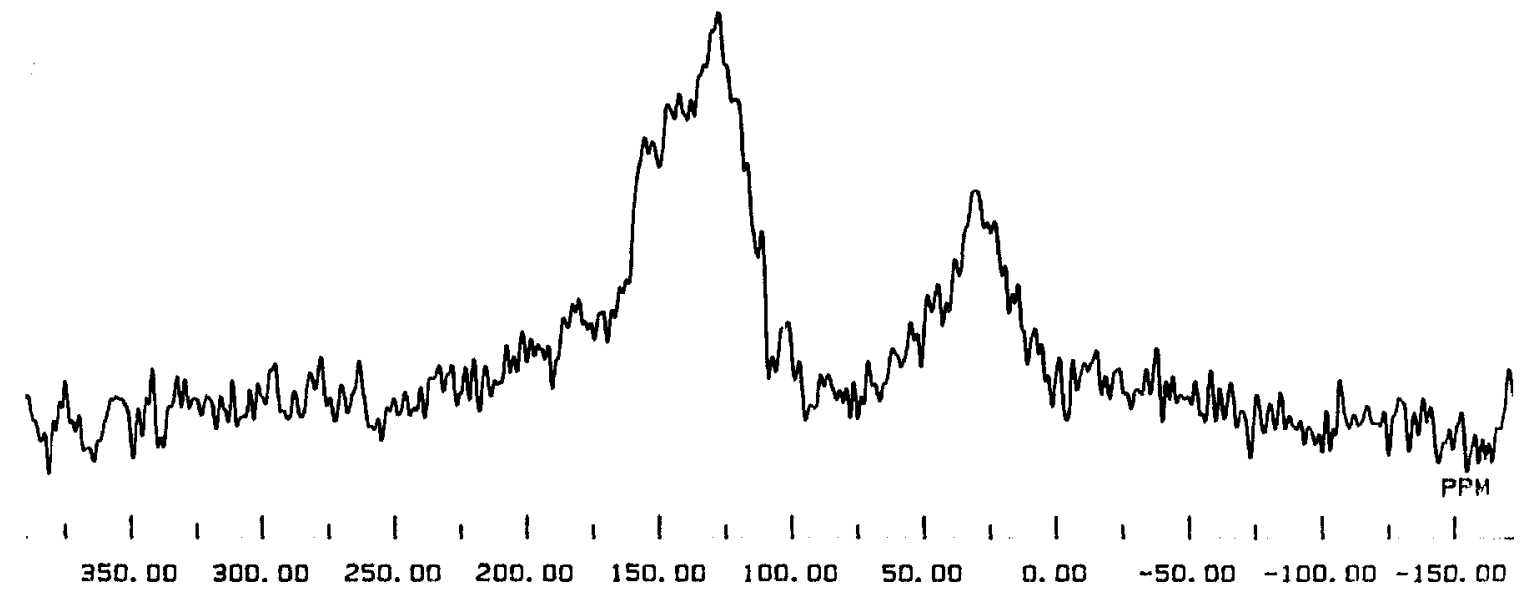

Figure 31. Bloch decay NMR spectrum of DECS-11, ligA Beulah seam, ND. 


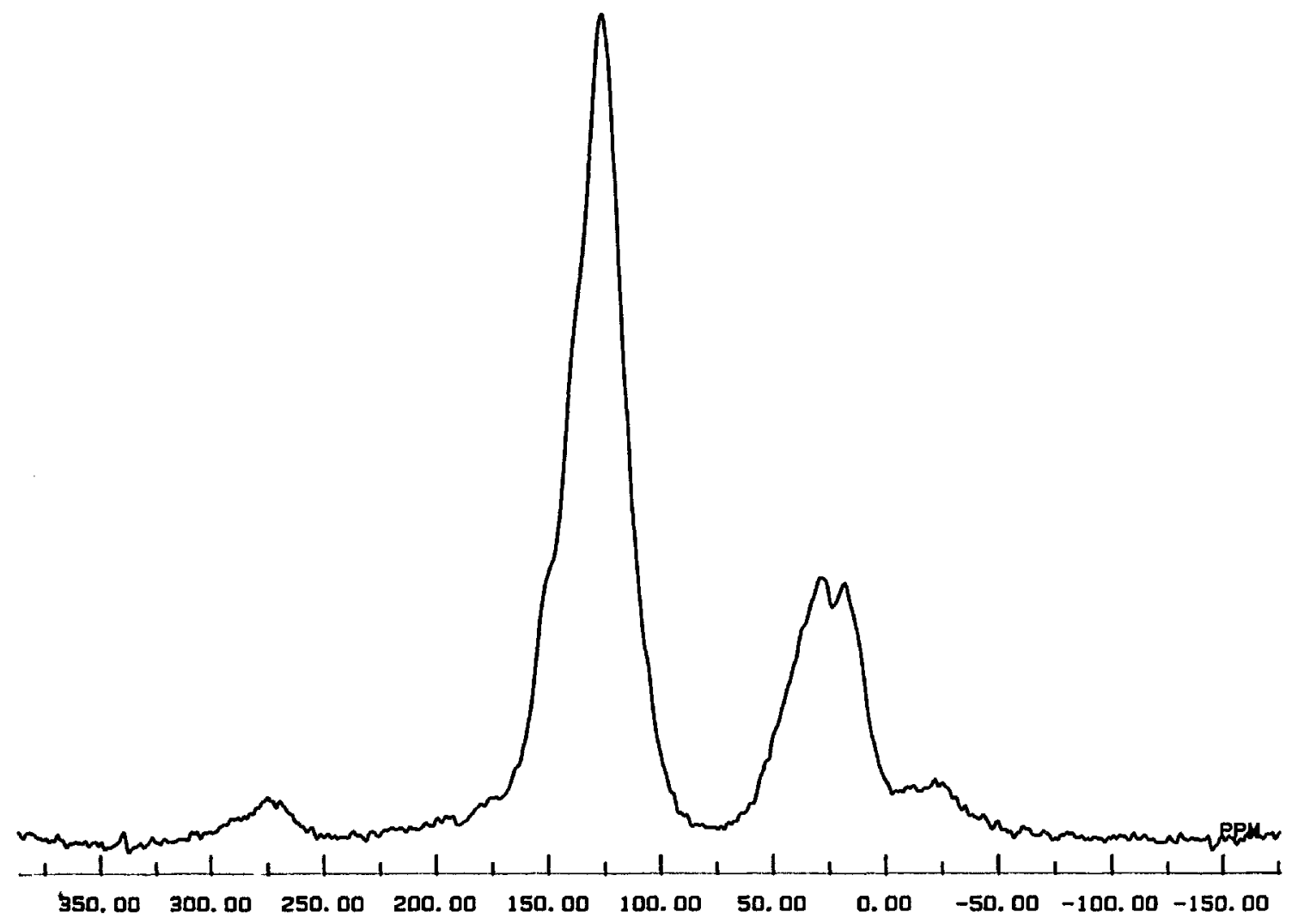

Figure 32. CPMAS NMR spectrum of DECS-12, hvAb Pittsburgh seam, PA.

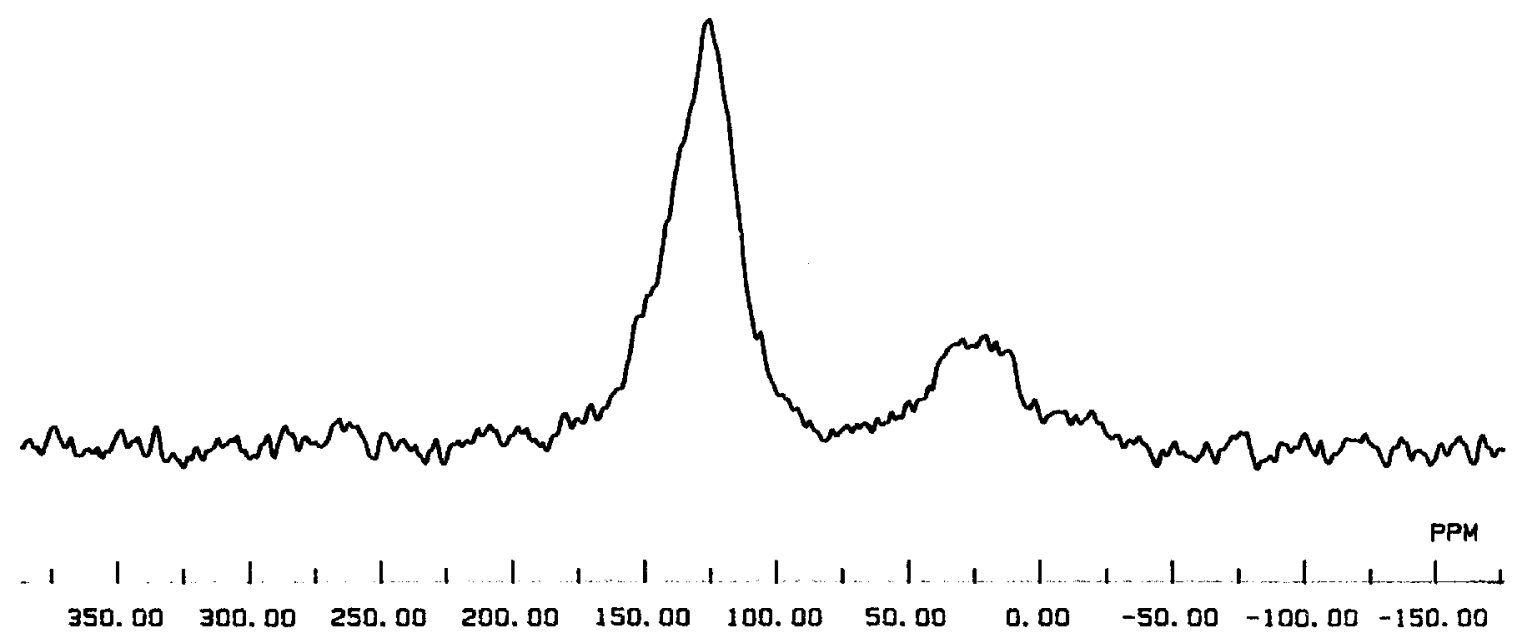

Figure 33. Bloch decay NMR spectrum of DECS-12, hvAb Pittsburgh seam, PA. 


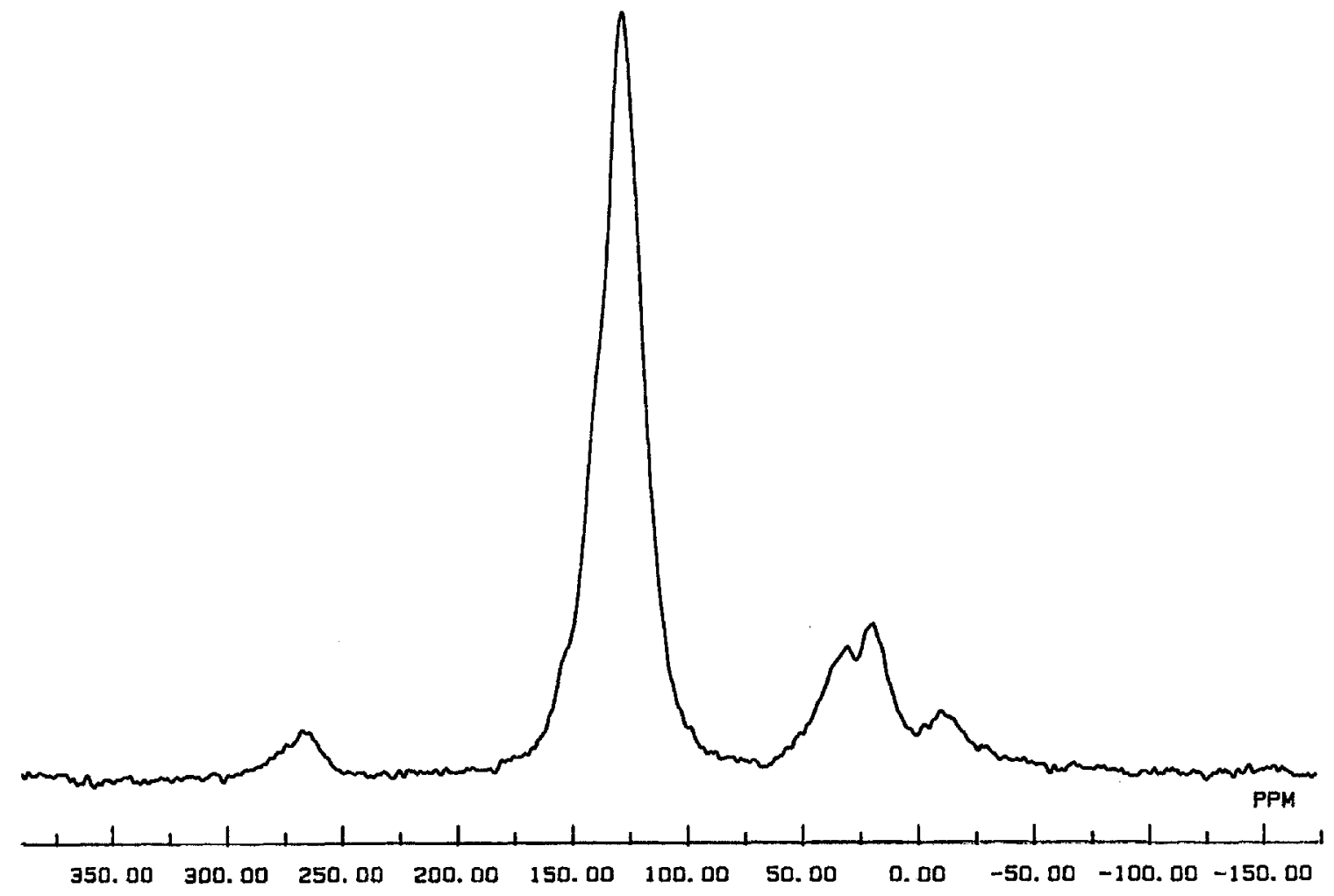

Figure 34. CPMAS NMR spectrum of DECS-13, mvb Sewell seam, WV.

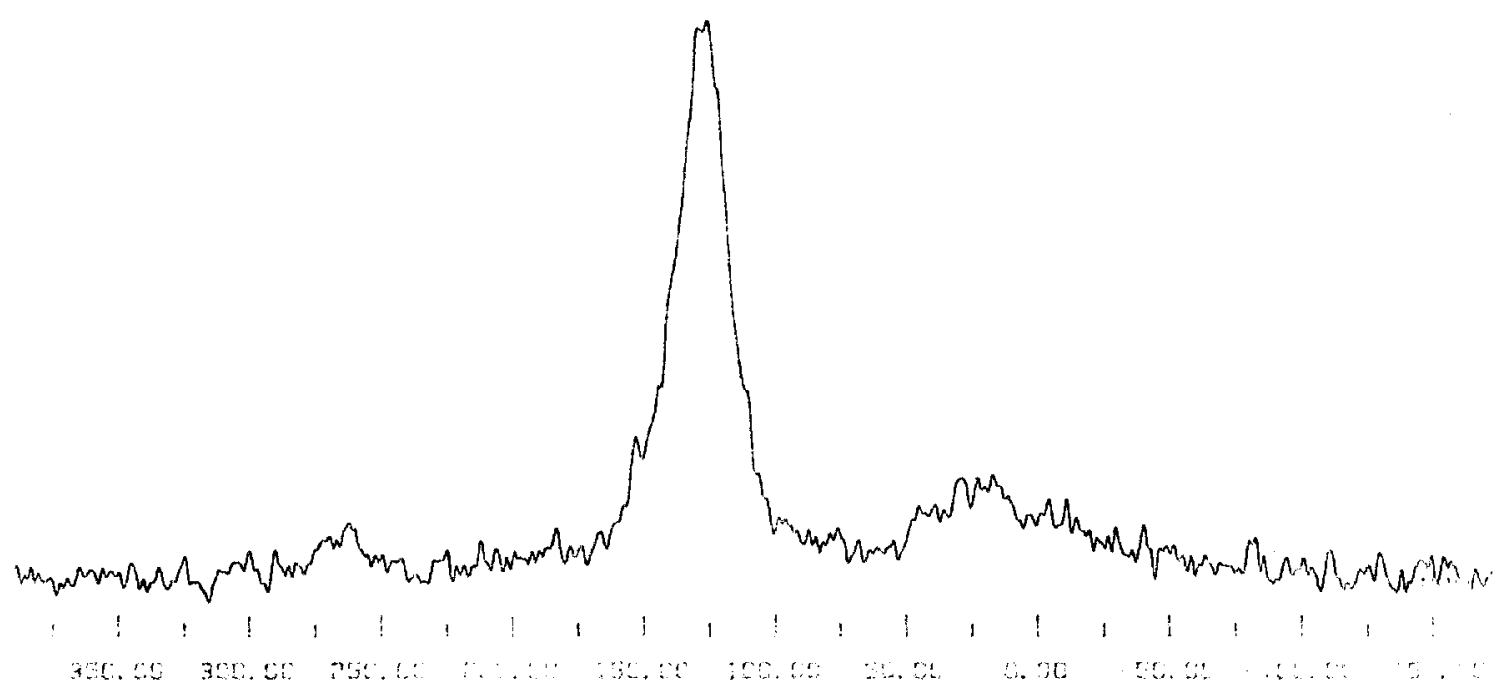

Figure 35. Bloch decay NMR spectrum of DECS-13, mvb Sewell seam, WV. 


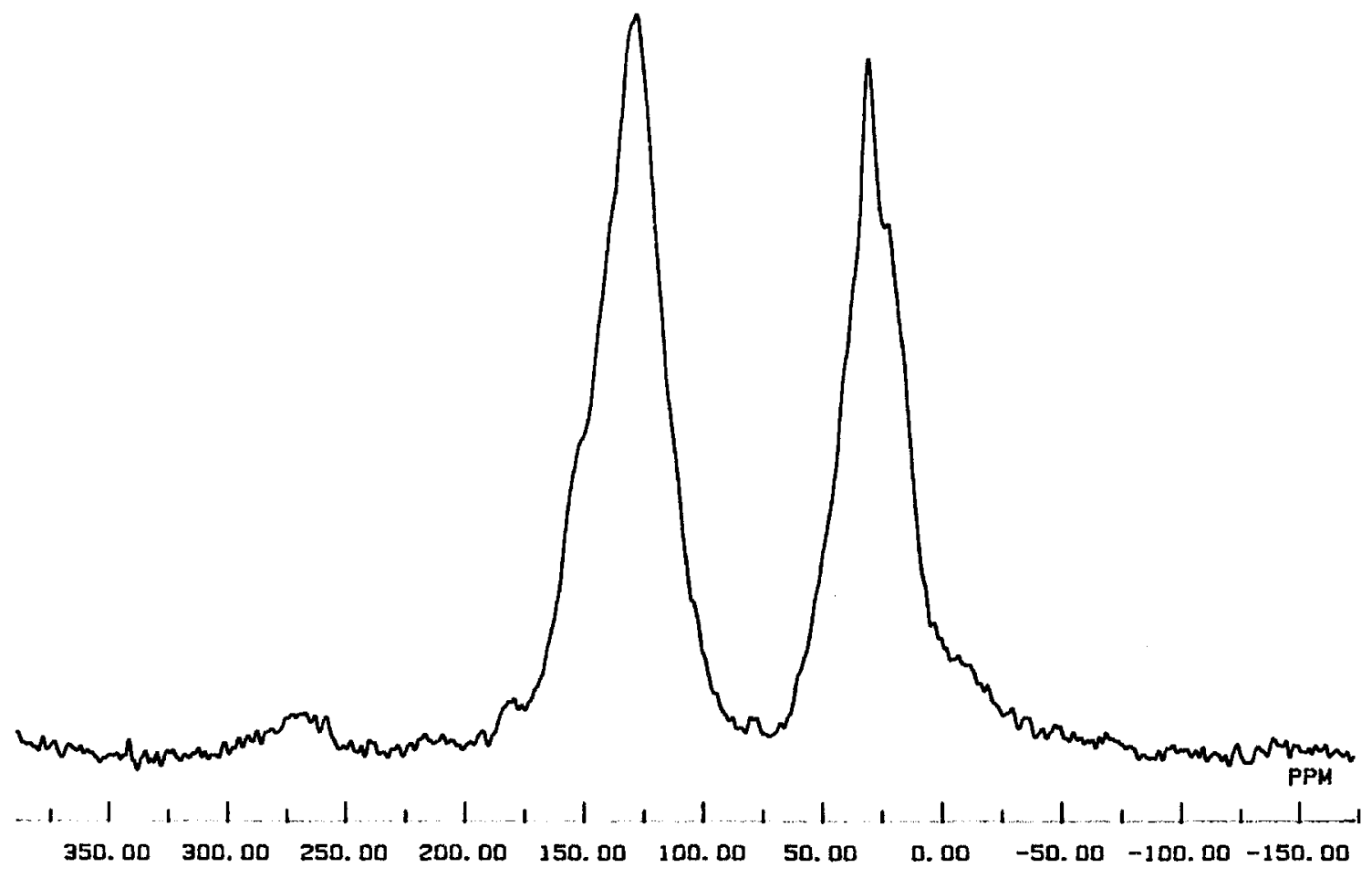

Figure 36. CPMAS NMR spectrum of DECS-17, hvAb Blind Canyon seam, UT.

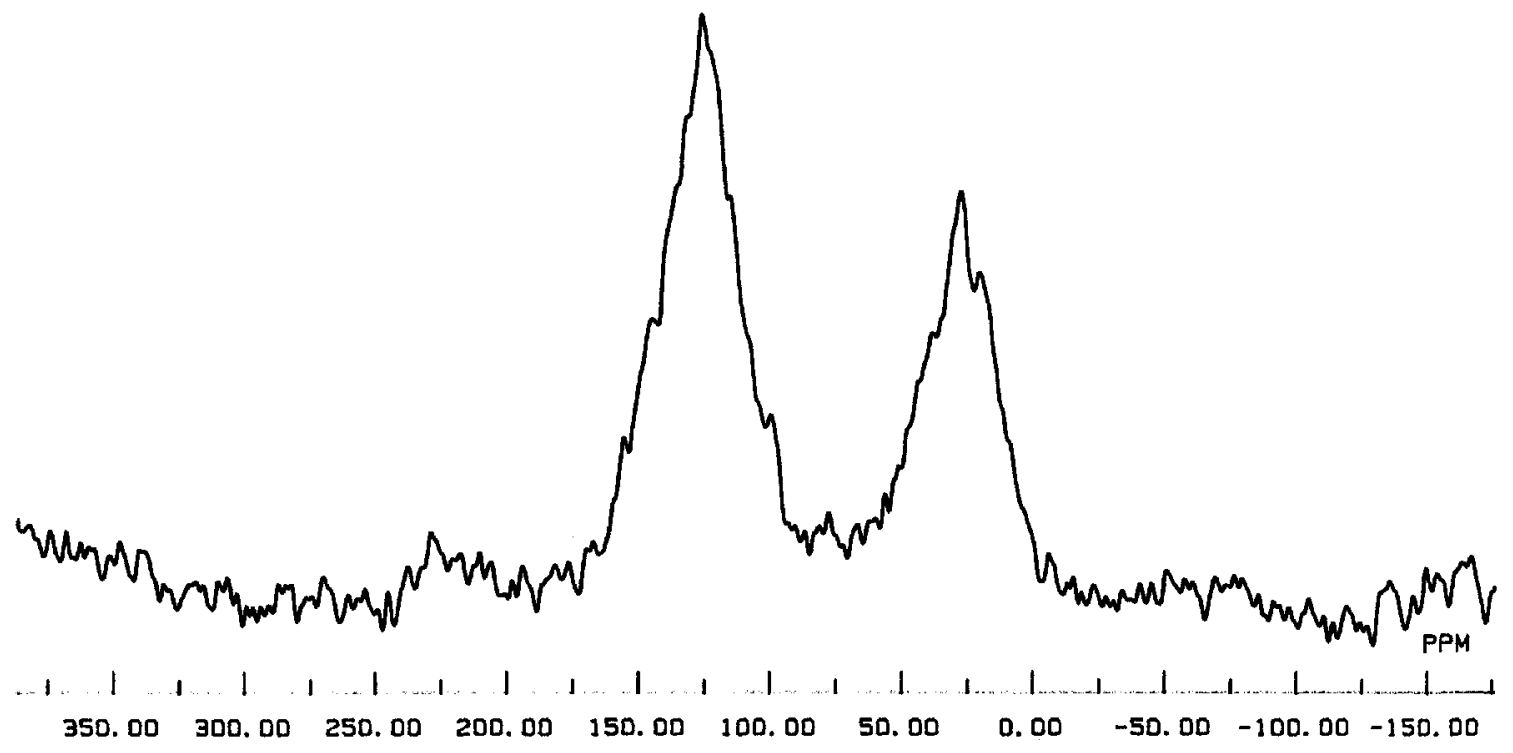

Figure 37. Bloch decay NMR spectrum of DECS-17, hvAb Blind Canyon seam, UT. 


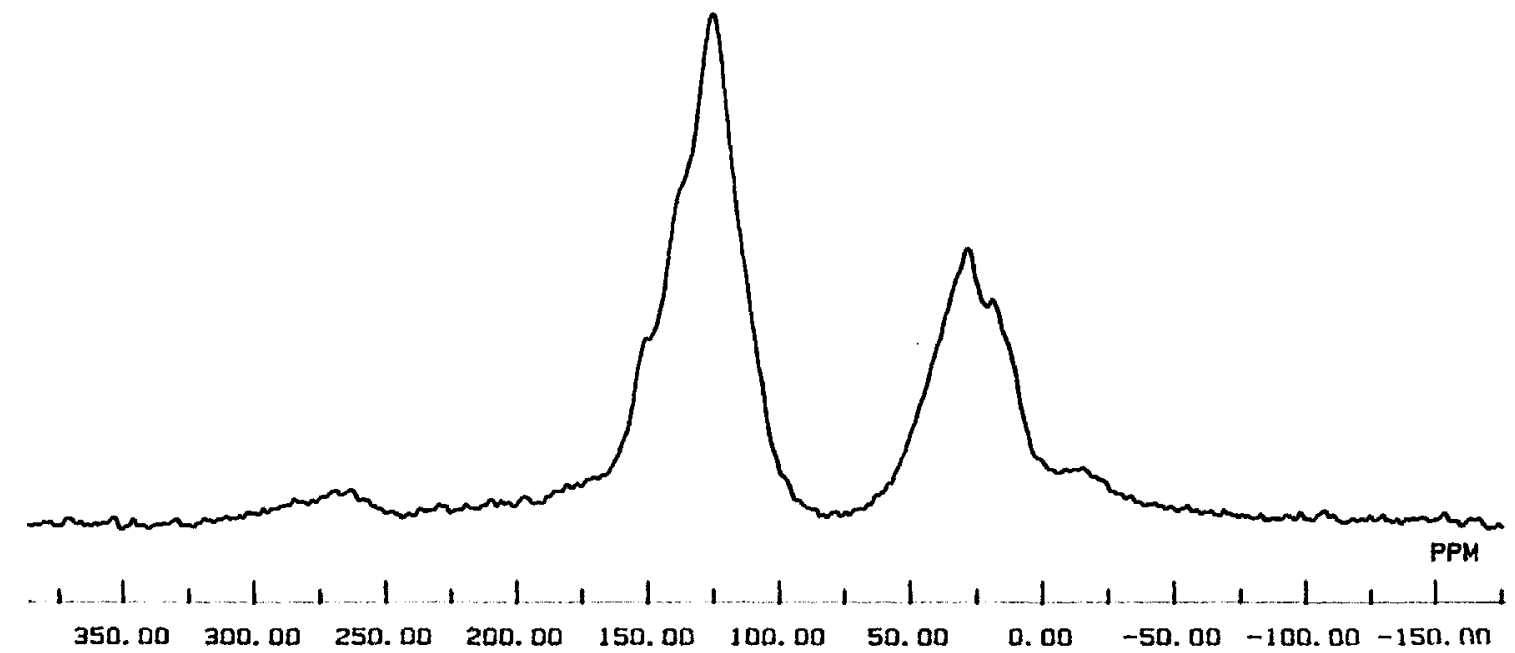

Figure 38. CPMAS NMR spectrum of DECS-18, hvBb Kentucky \#9 seam, KY.

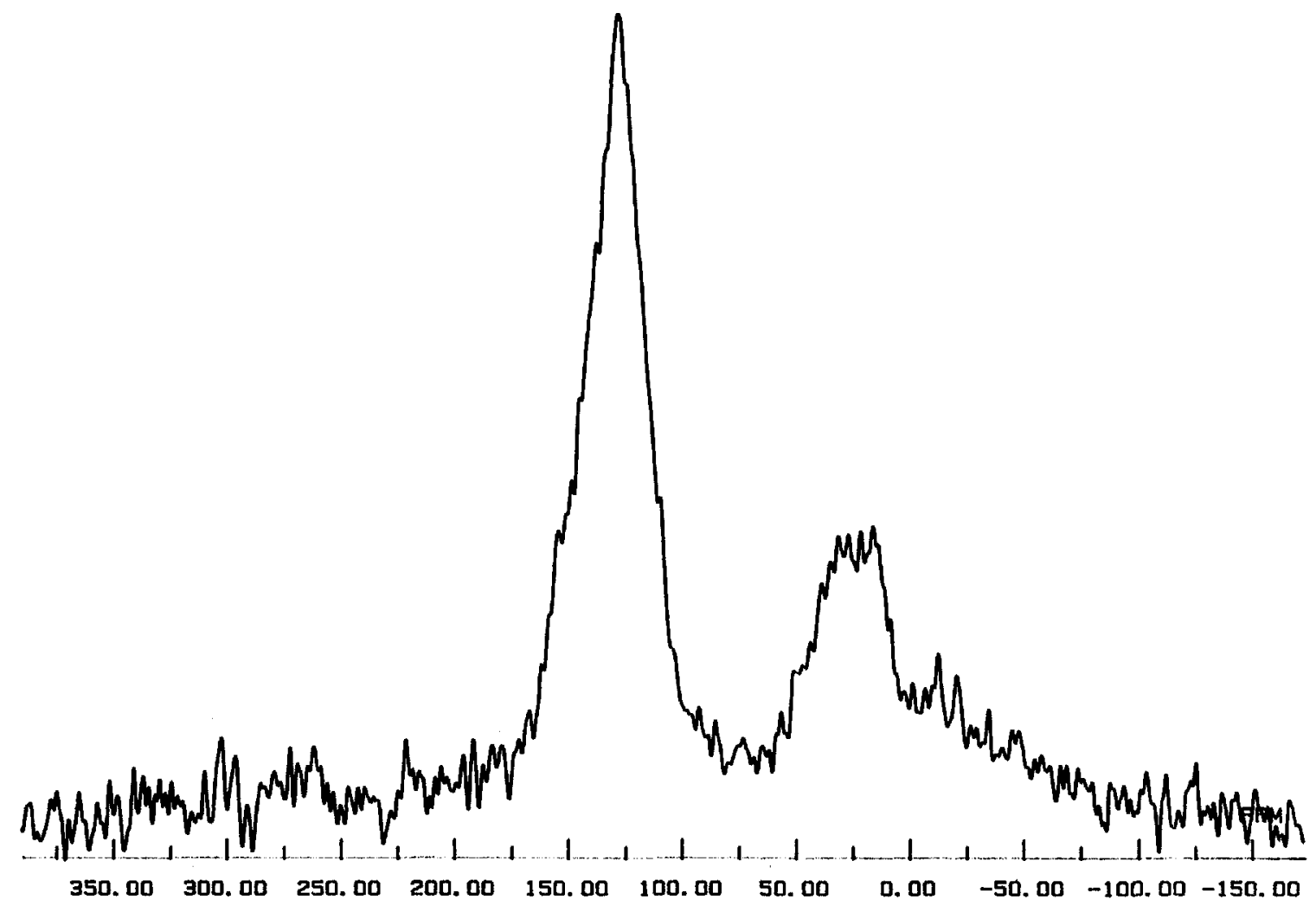

Figure 39. Bloch decay NMR spectrum of DECS-18, hvBb Kentucky \#9 seam, KY. 


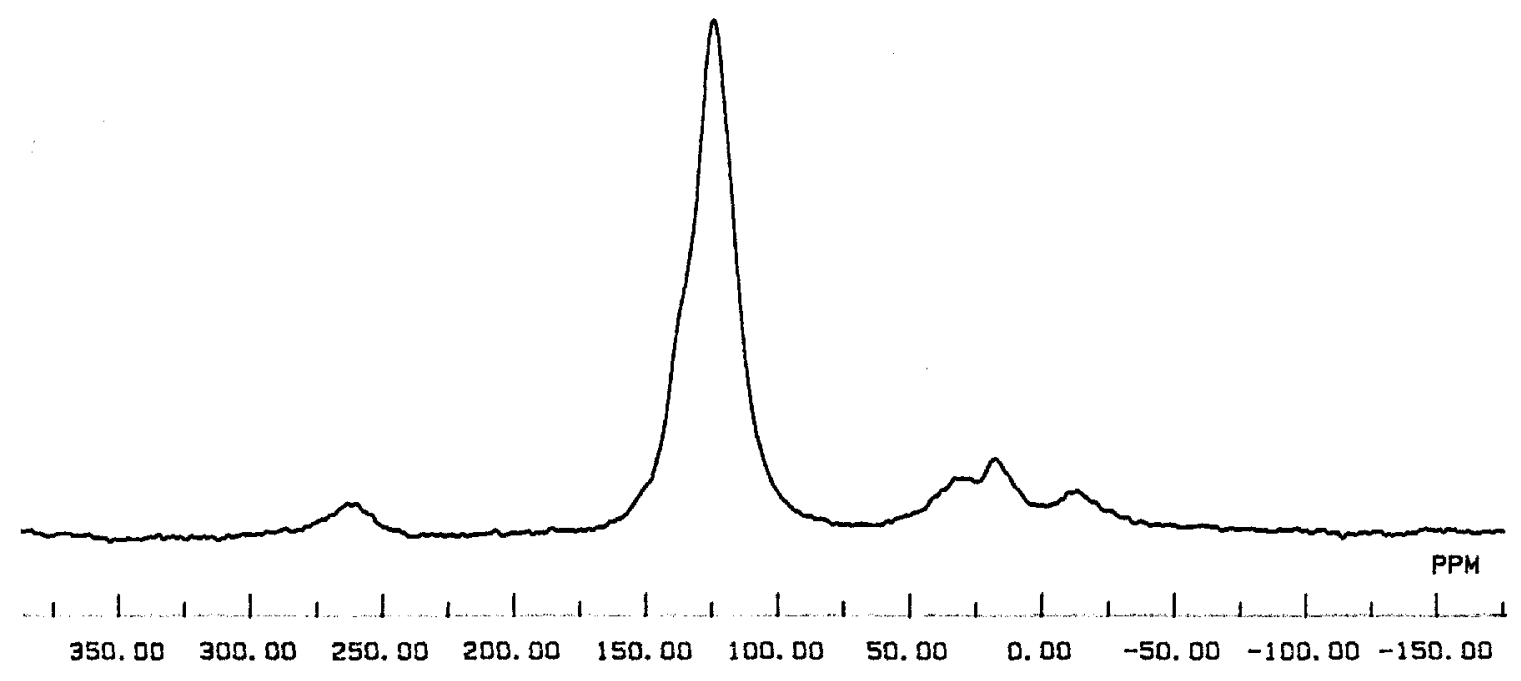

Figure 40. CPMAS NMR spectrum of DECS-19, 1vb Pocahontas \#3 seam, VA.

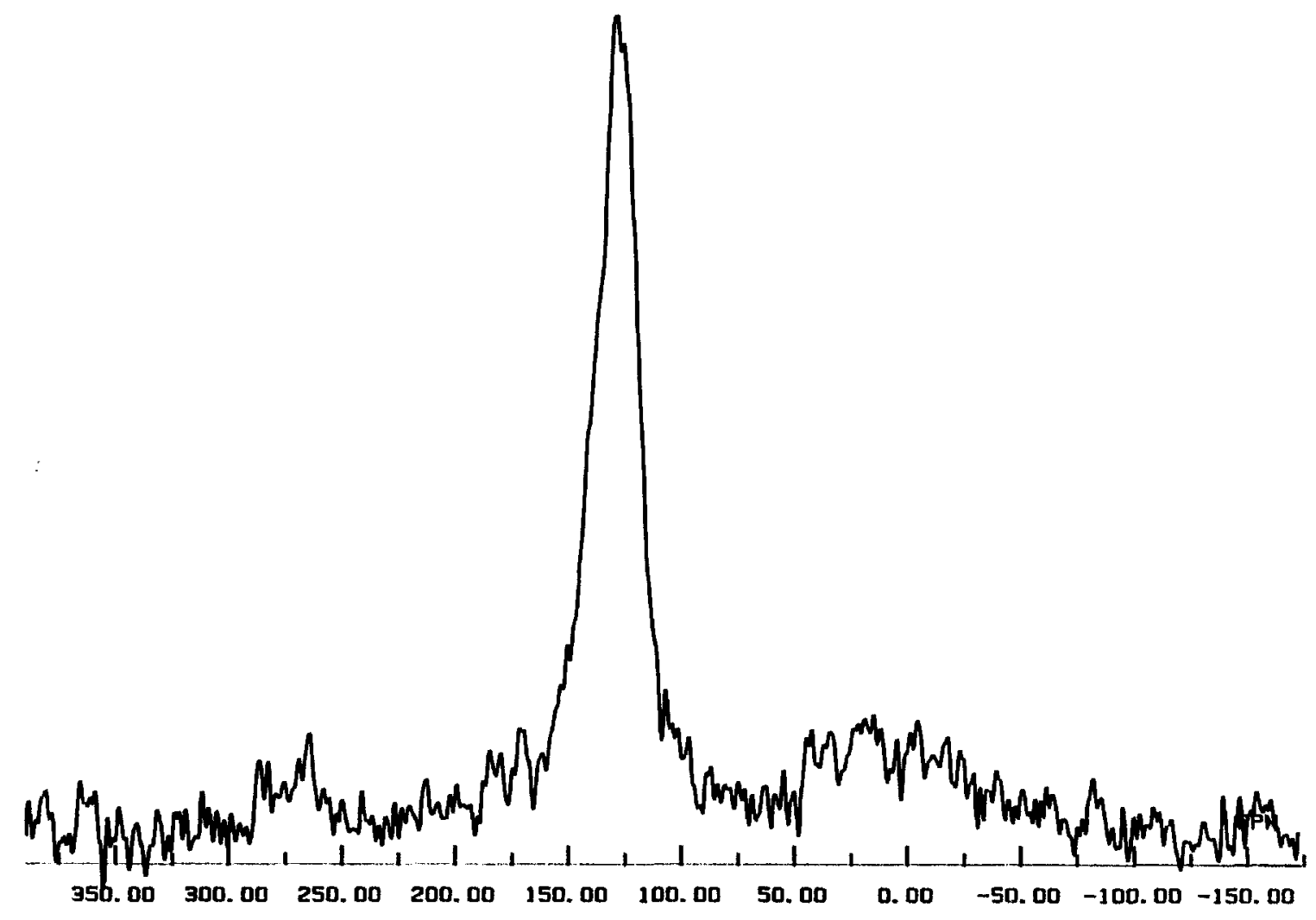

Figure 41. Bloch decay NMR spectrum of DECS-19, lvb Pocahontas \#3 seam, VA. 


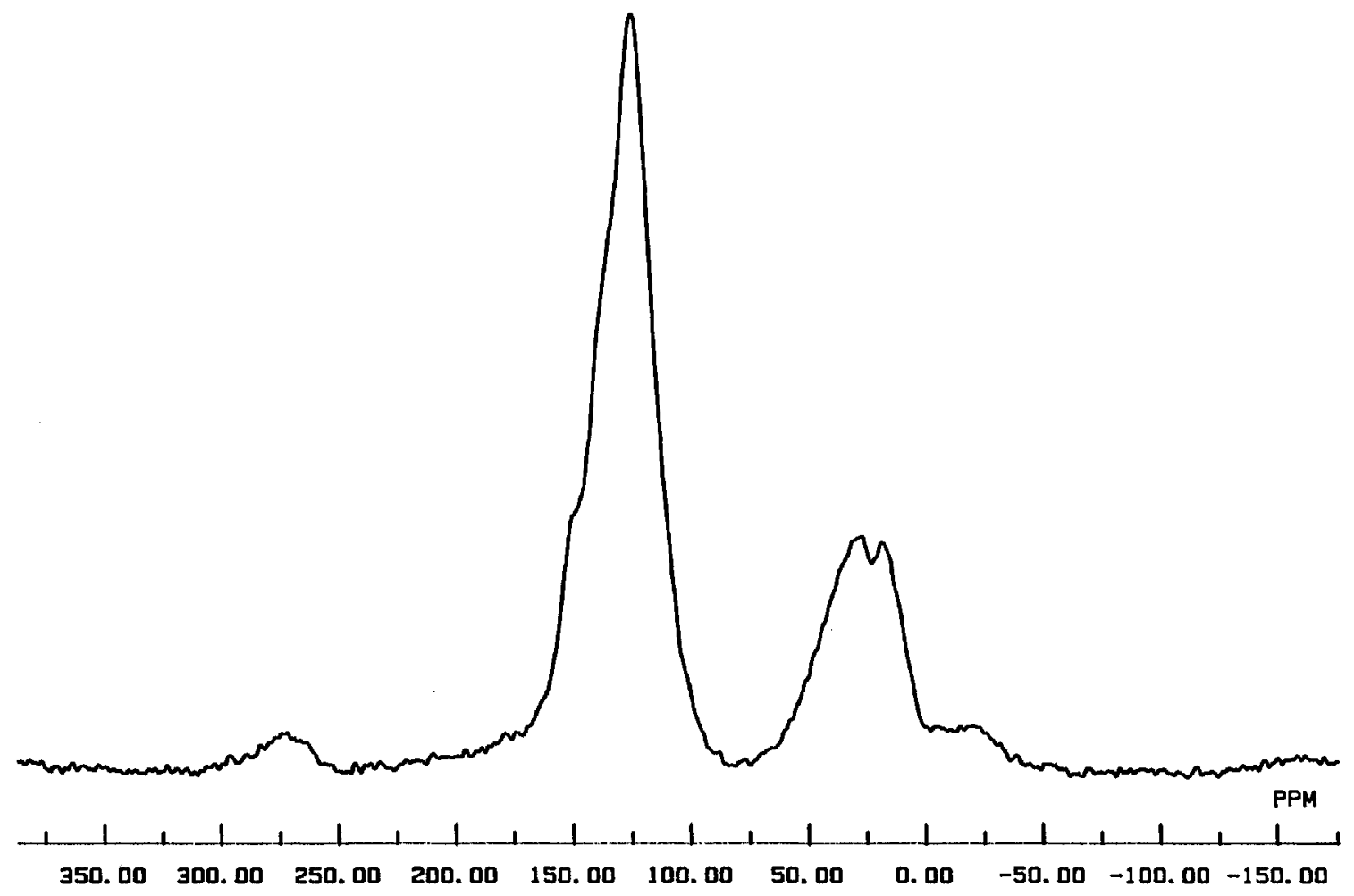

Figure 42. CPMAS NMR spectrum of DECS-23, hvAb Pittsburgh seam, PA.

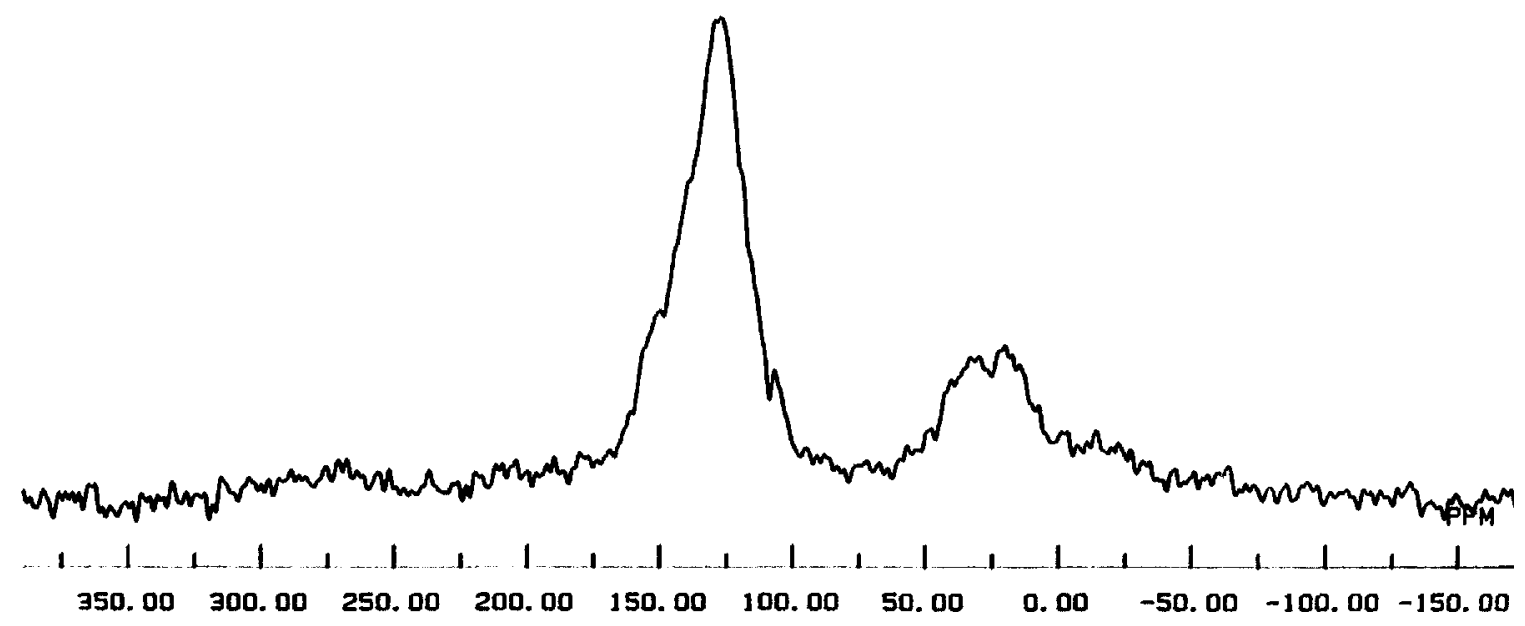

Figure 43. Bloch decay NMR spectrum of DECS-23, hvAb Pittsburgh seam, PA. 


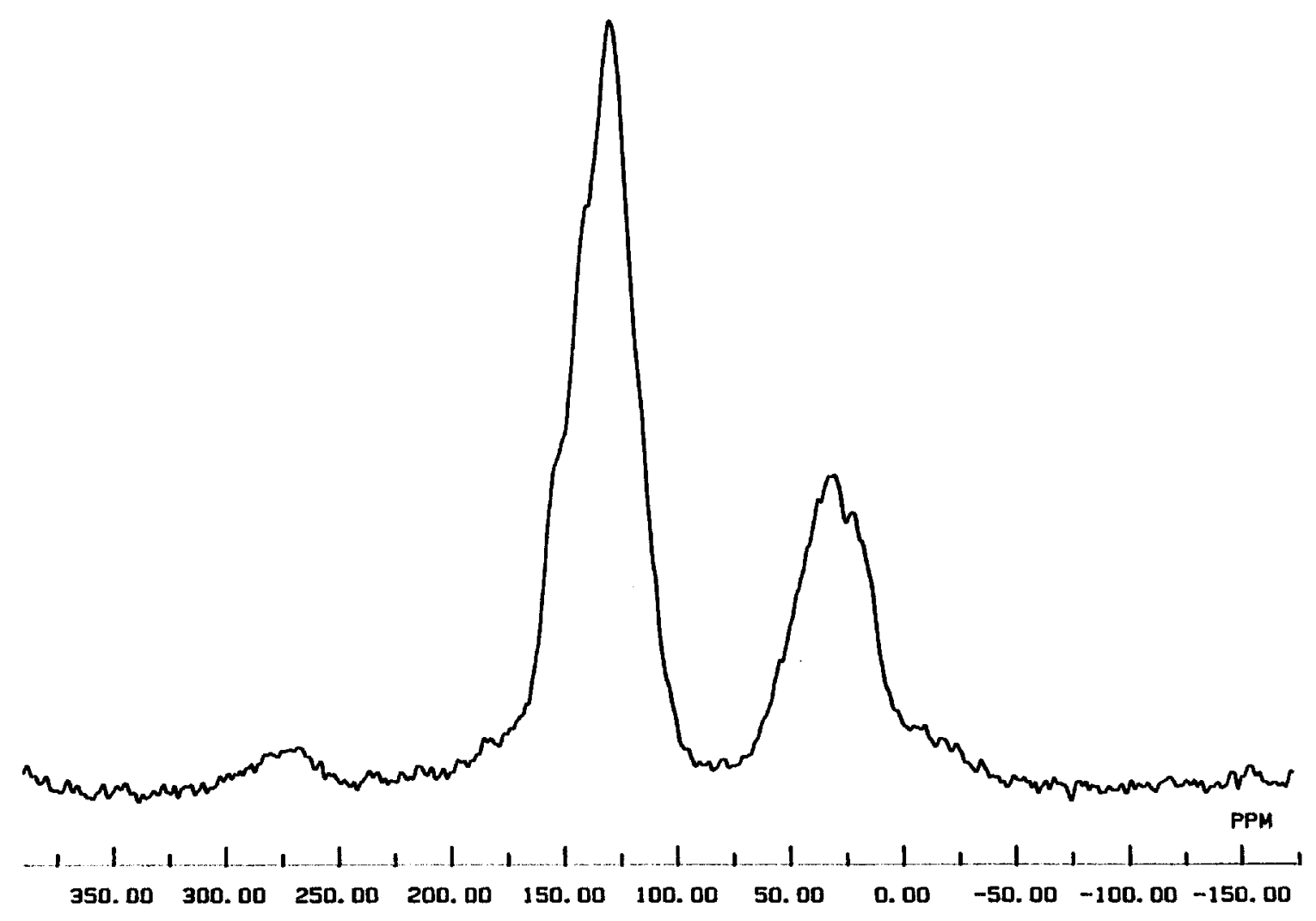

Figure 44. CPMAS NMR spectrum of DECS-24, hvCb Illinois \#6 seam, IL.

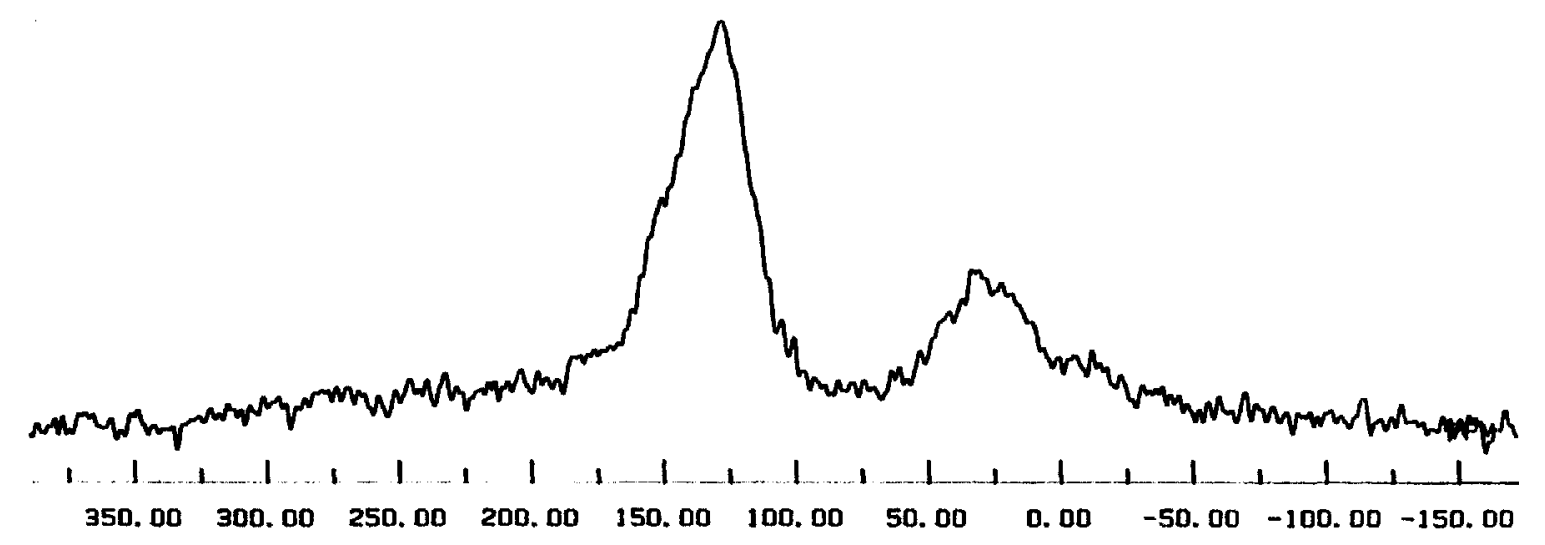

Figure 45. Bloch decay NMR spectrum of DECS-24, hvCb Illinois \#6 seam, IL. 


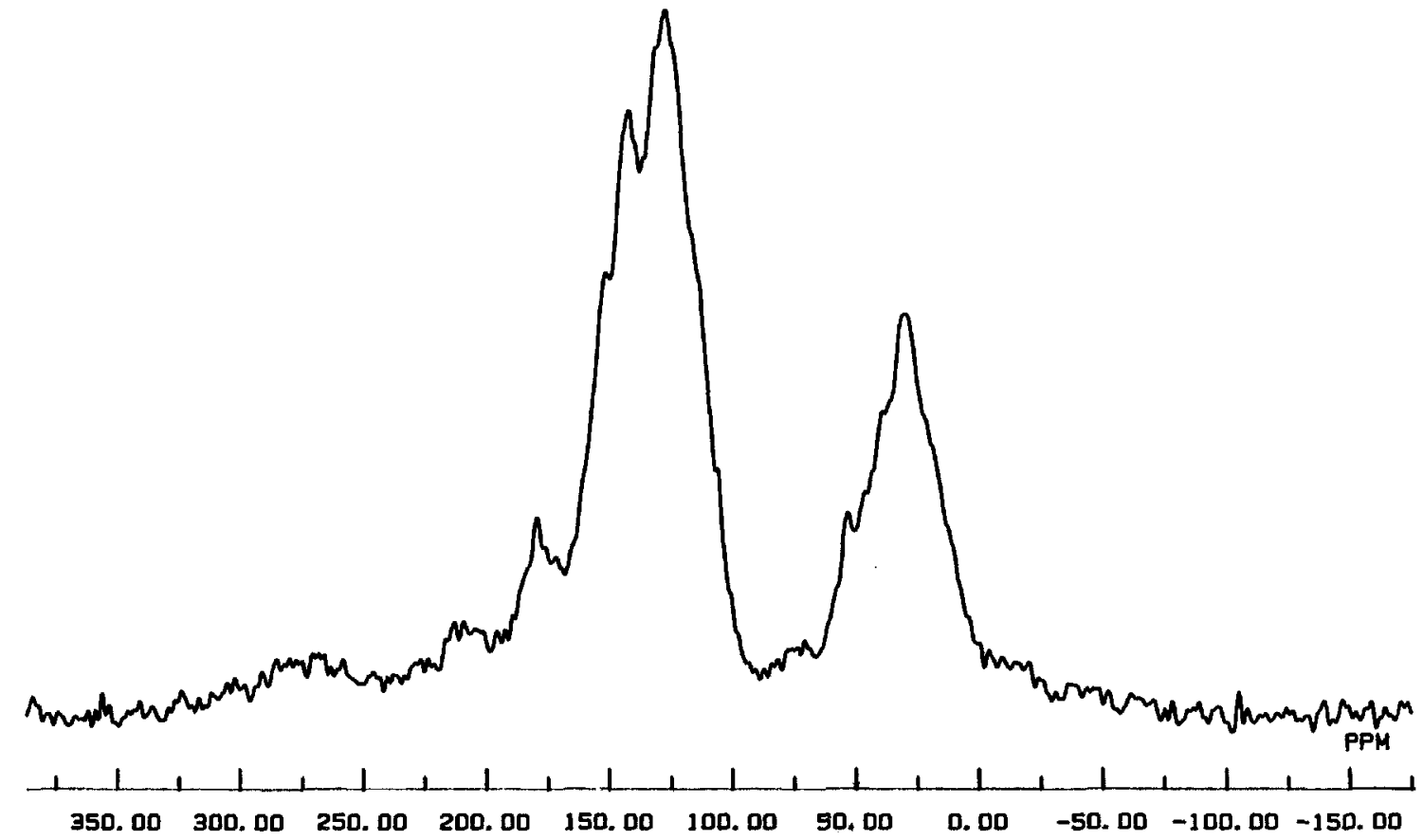

Figure 46. CPMAS NMR spectrum of DECS-25, ligA Pust seam, MT.

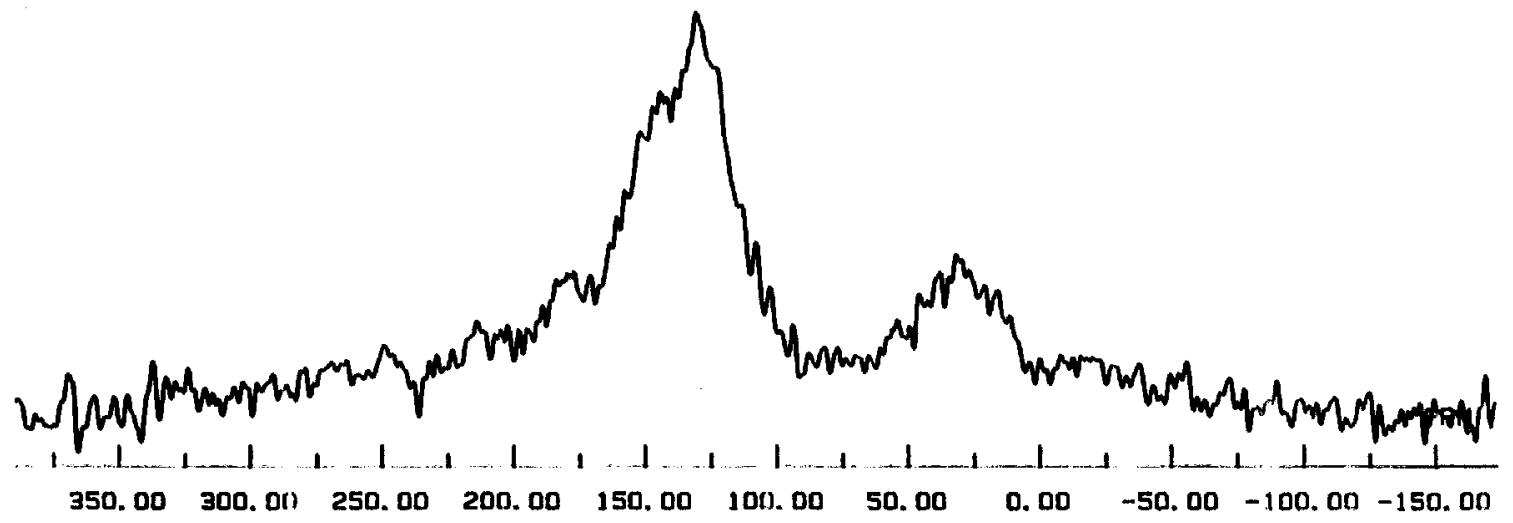

Figure 47. Bloch decay NMR spectrum of DECS-25, ligA Pust seam, MT. 


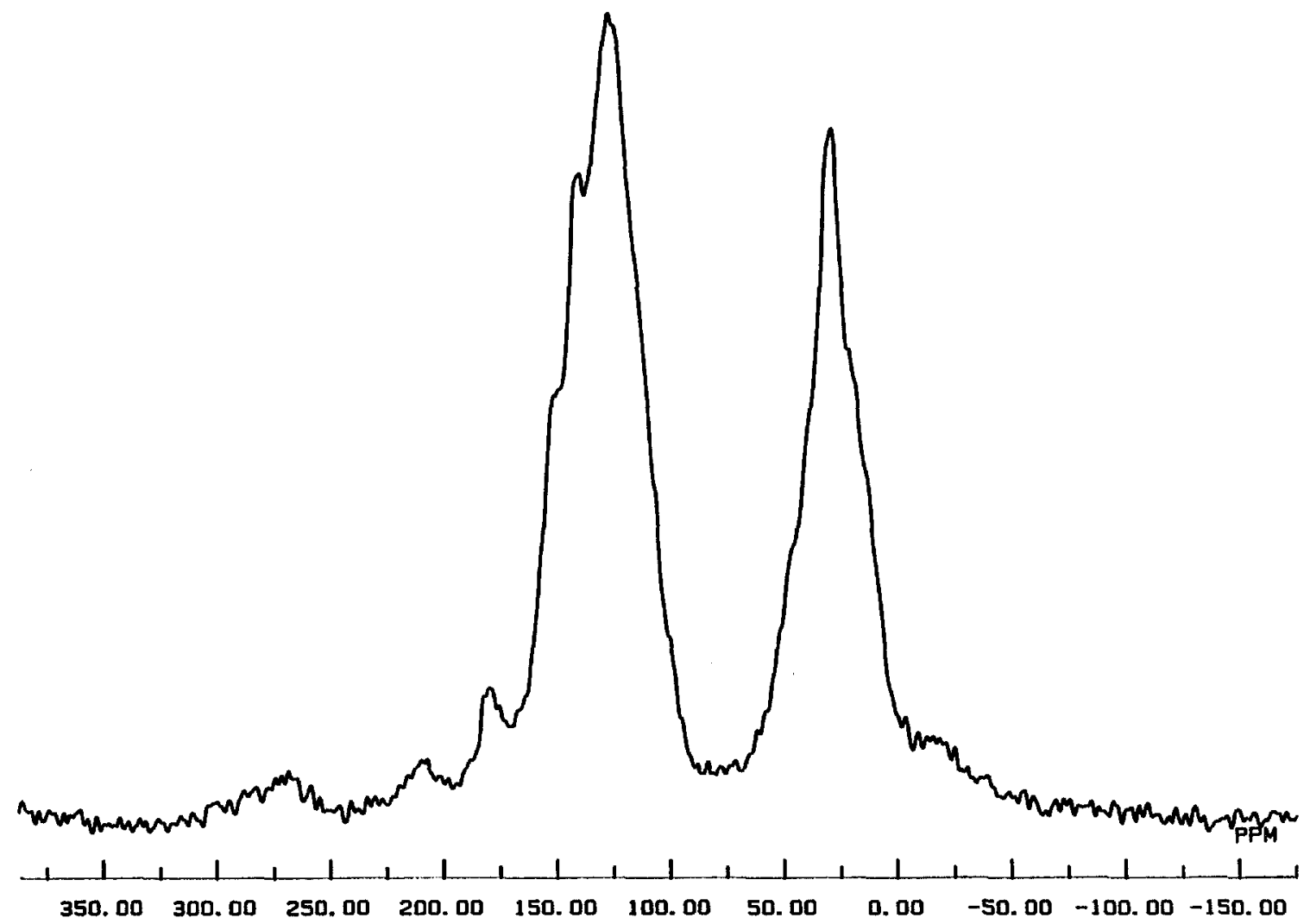

Figure 48. CPMAS NMR spectrum of DECS-26, subB Wyodak seam, WY.

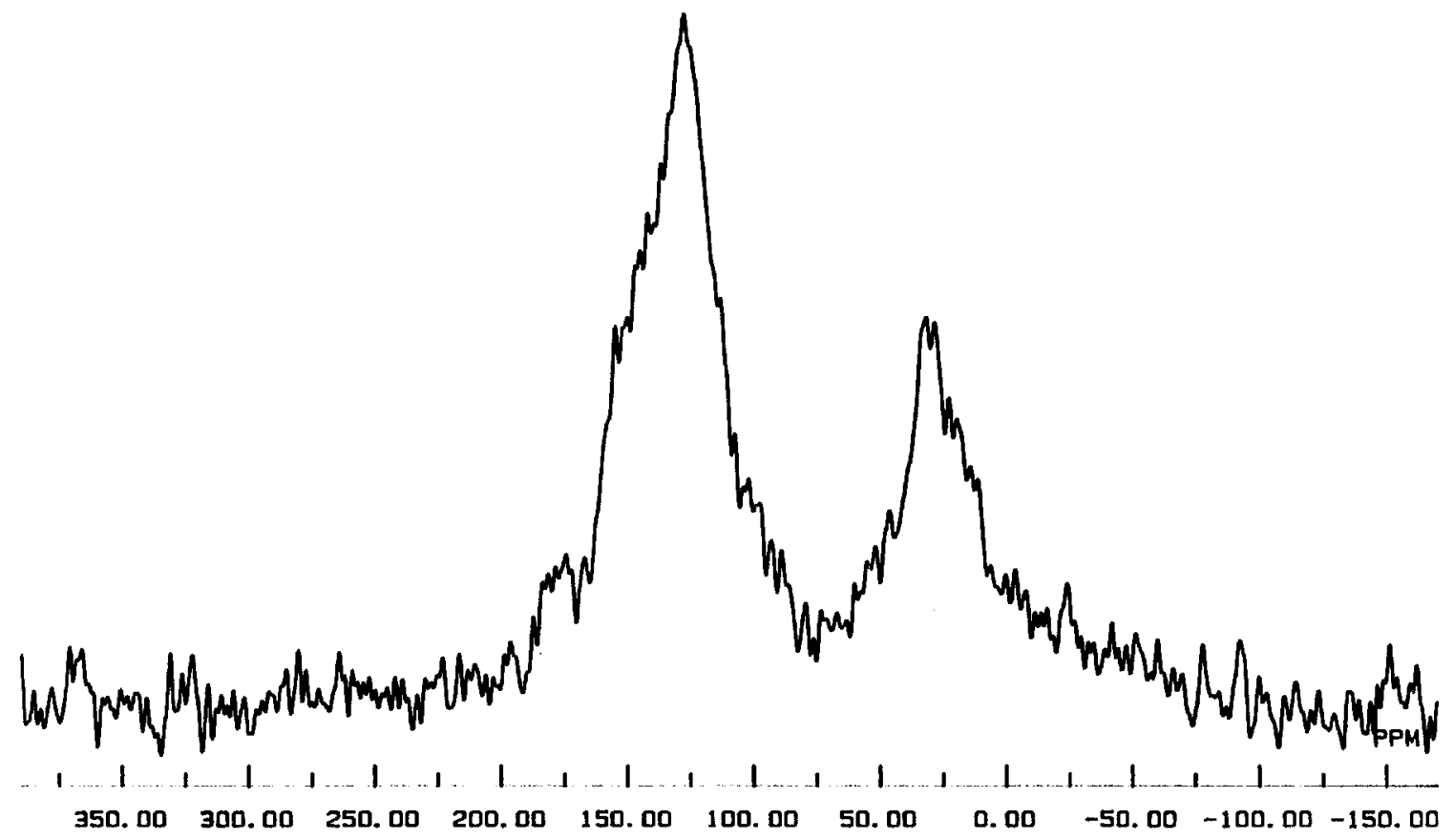

Figure 49. Bloch decay NMR spectrum of DECS-26, subB Wyodak seam, WY. 


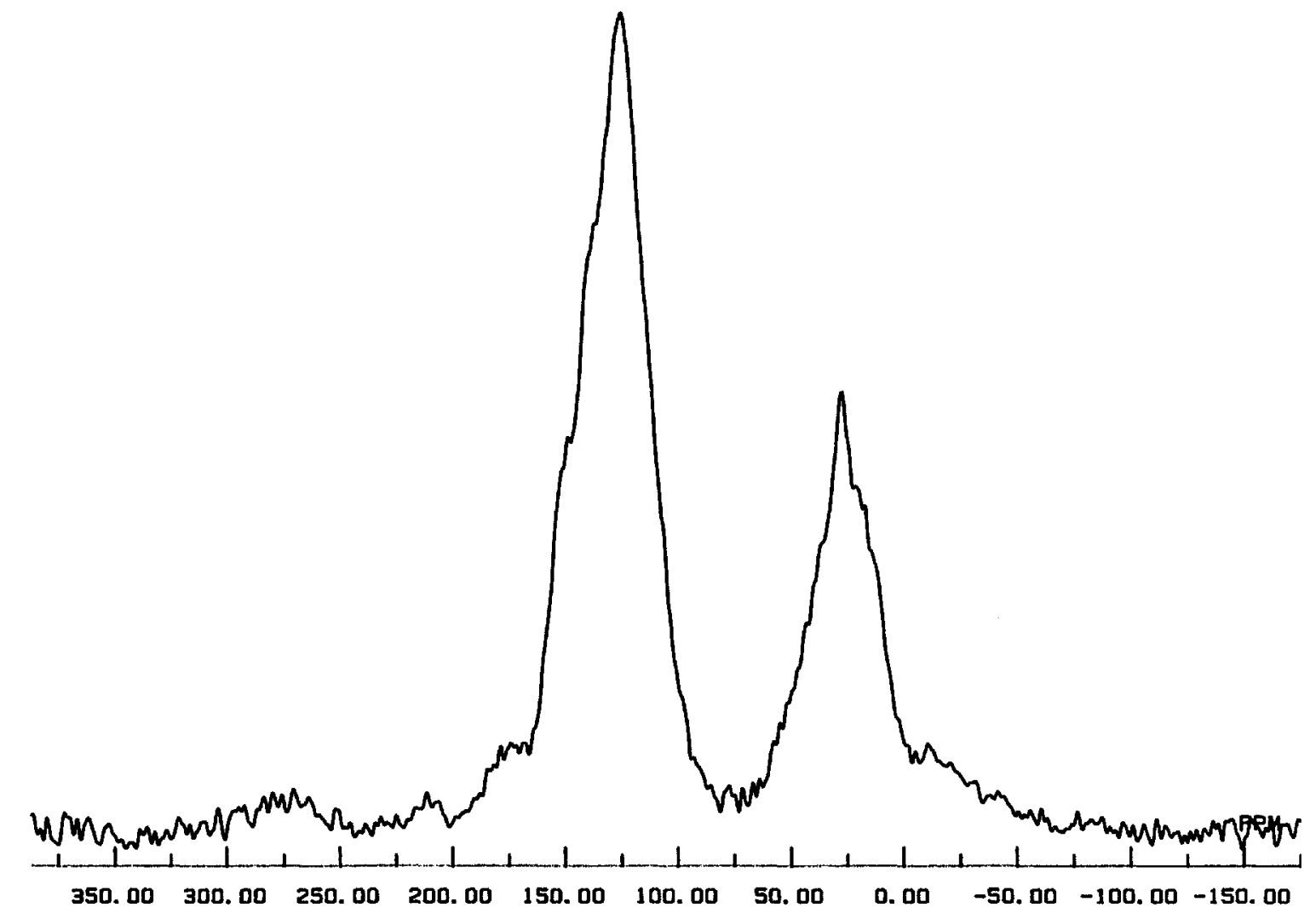

Figure 50. CPMAS NMR spectrum of DECS-27, subA Deadman seam, WY.

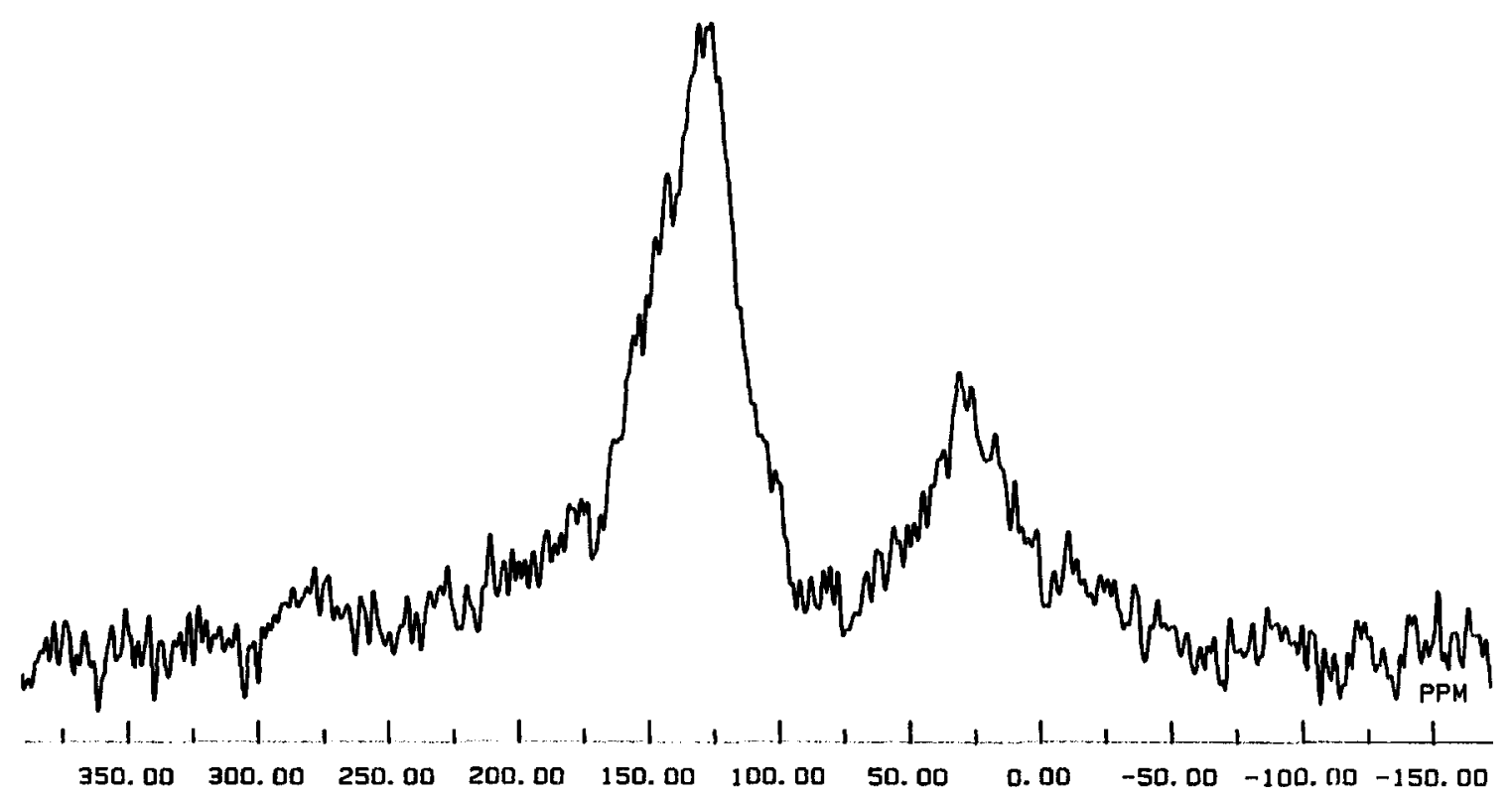

Figure 51. Bloch decay NMR spectrum of DECS-27, subA Deadman seam, WY. 


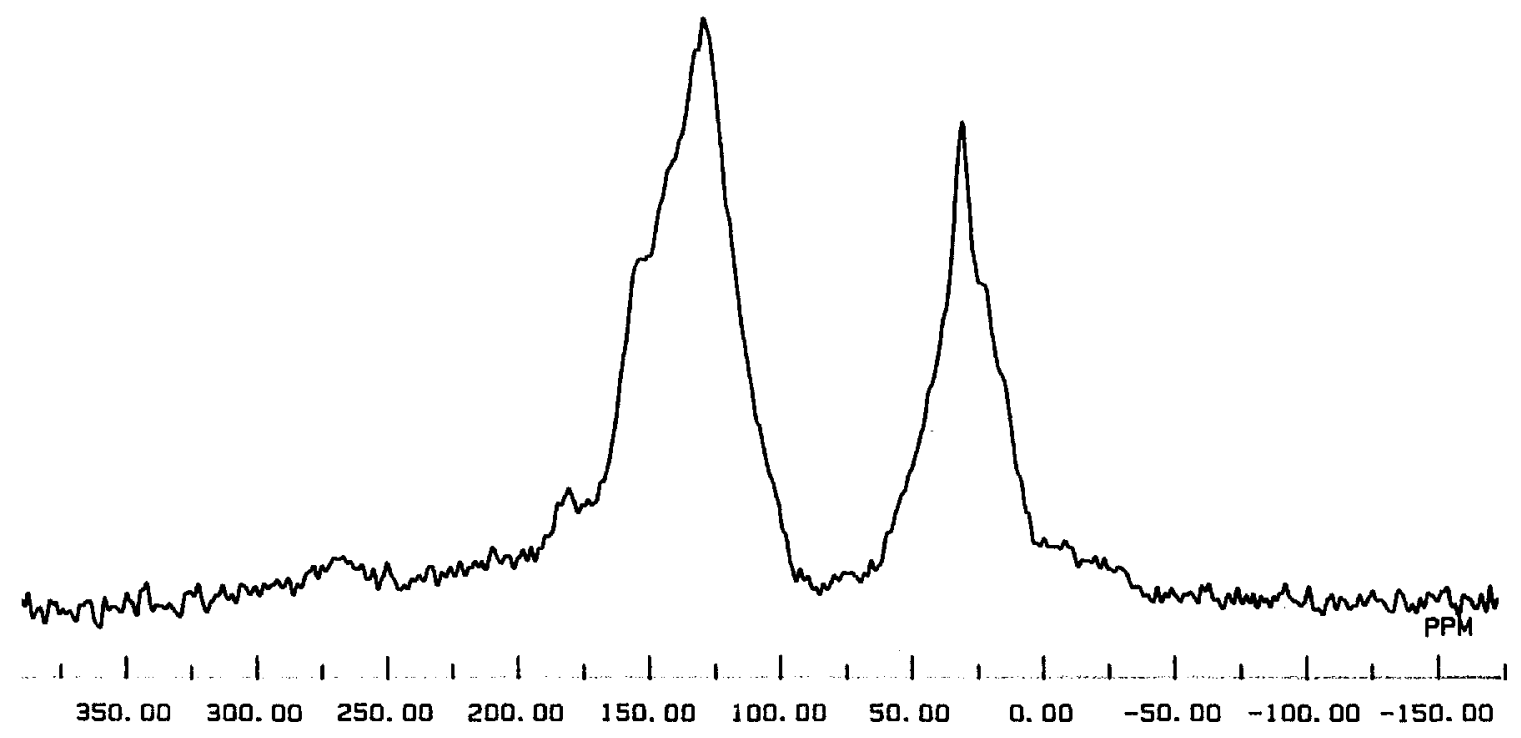

Figure 52. CPMAS NMR spectrum of DECS-28, hvCb Green seam, AZ.

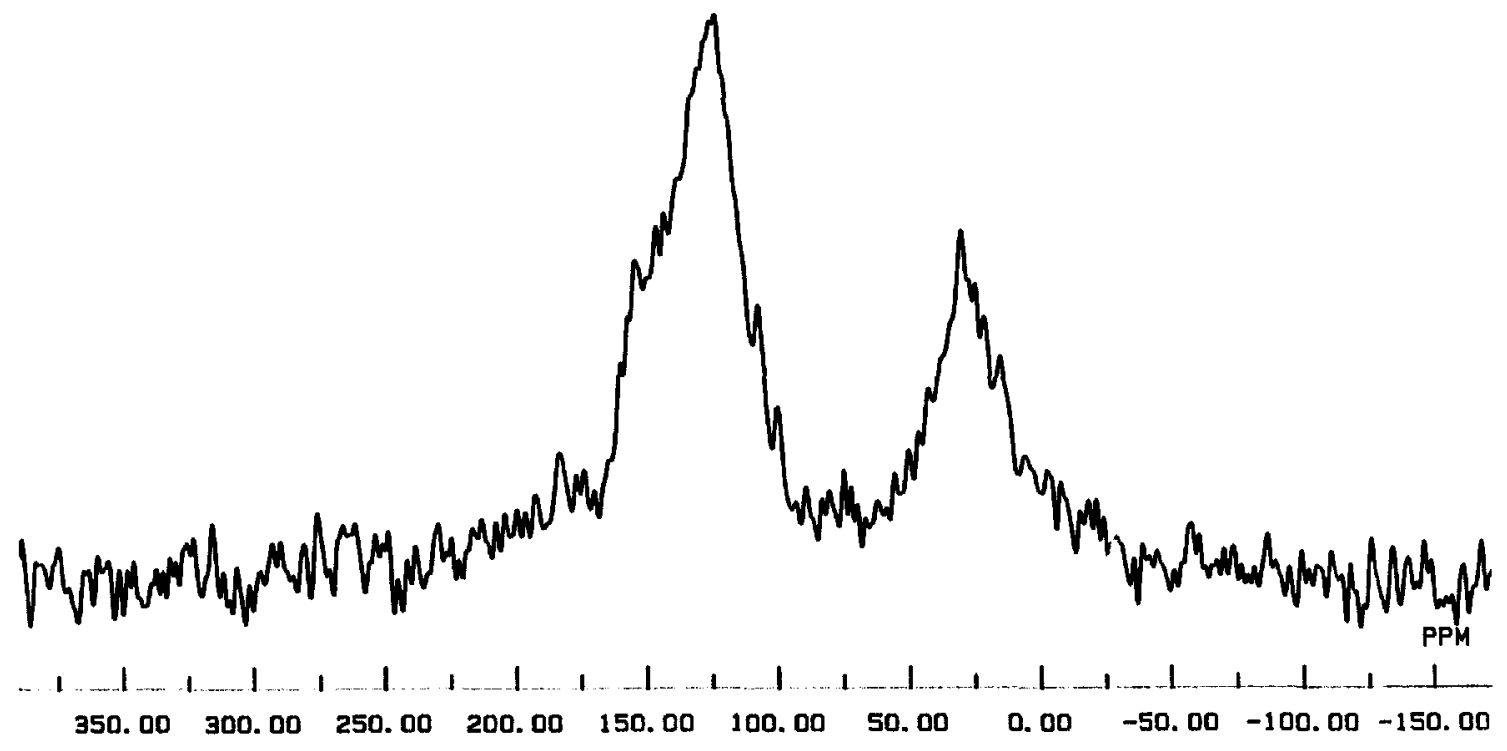

Figure 53. Bloch decay NMR spectrum of DECS-28, hvCb Green seam, AZ. 

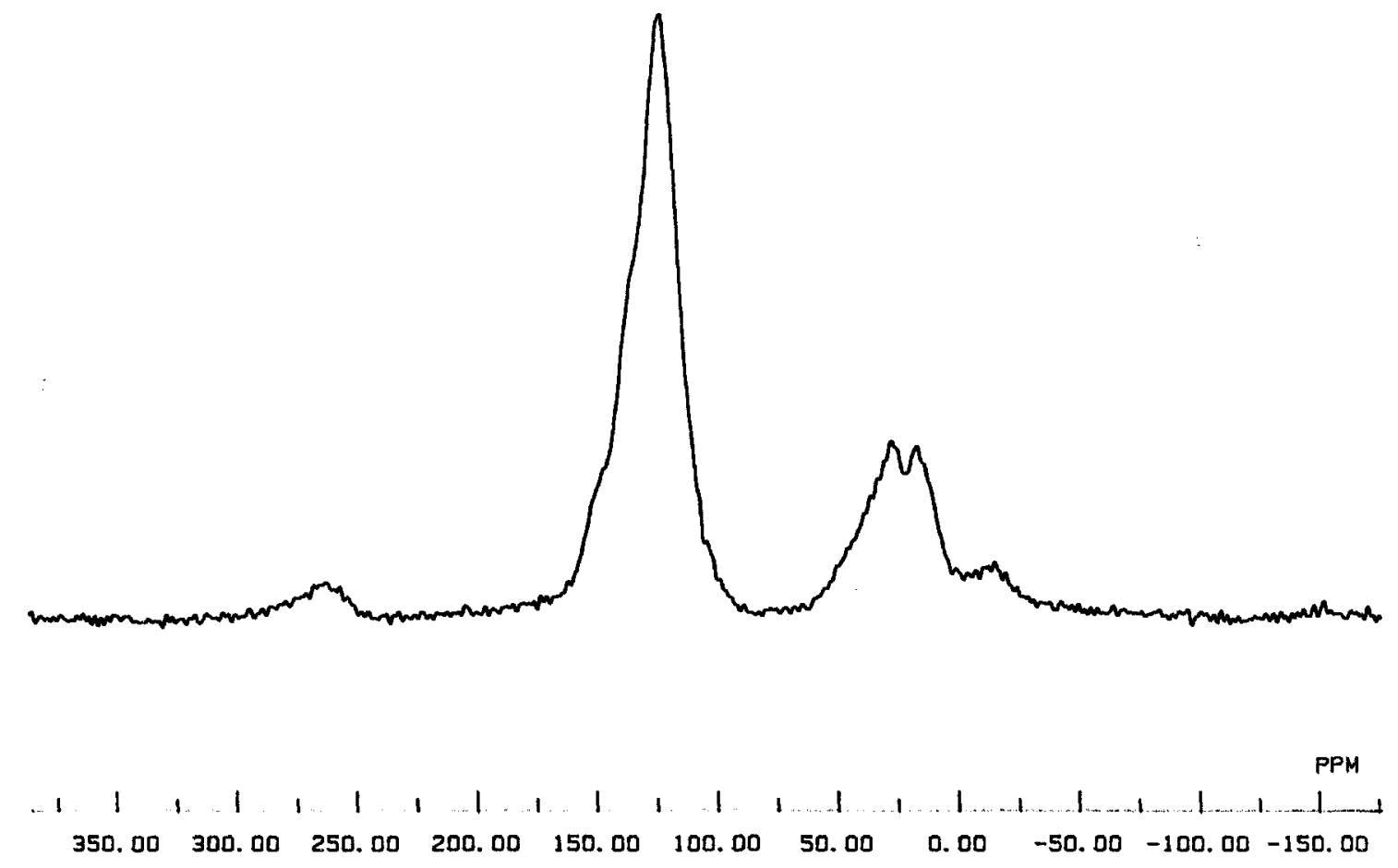

Figure 54. CPMAS NMR spectrum of DECS-29, hvAb Upper Banner seam, VA.

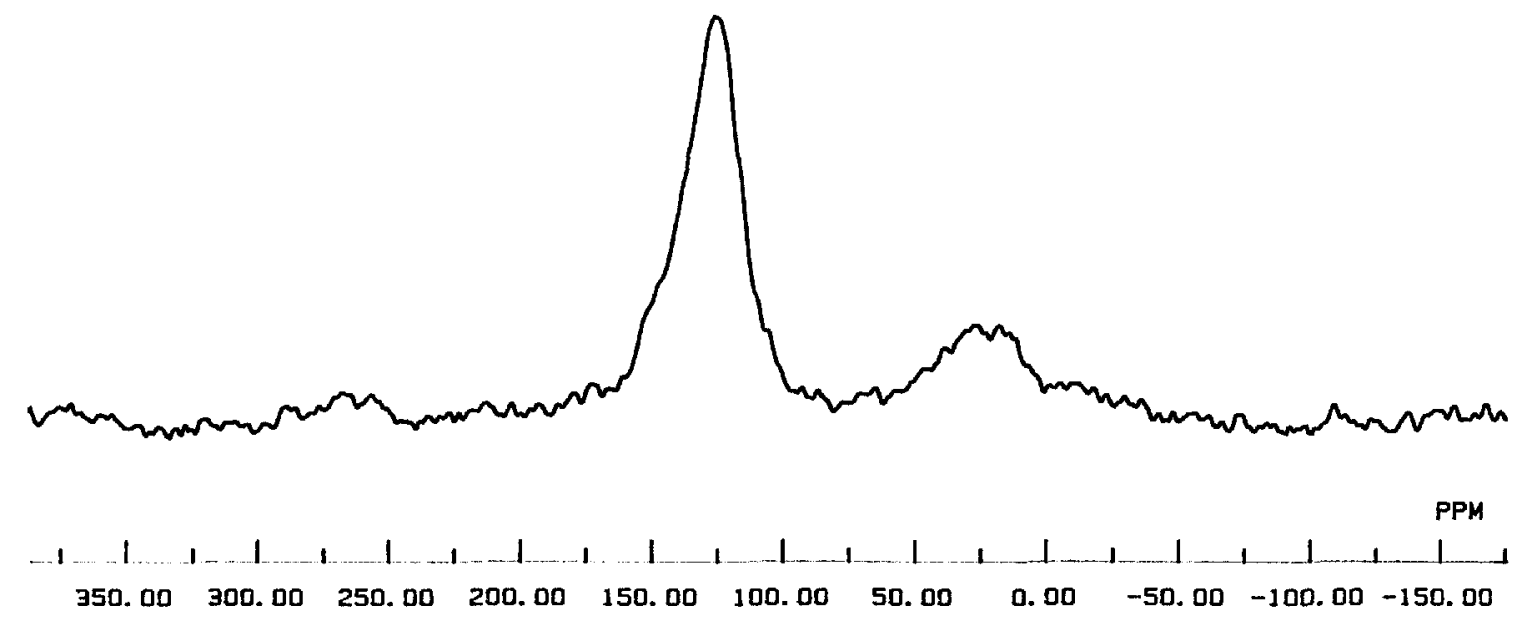

Figure 55. Bloch decay NMR spectrum of DECS-29, hvAb Upper Banner seam, VA. 


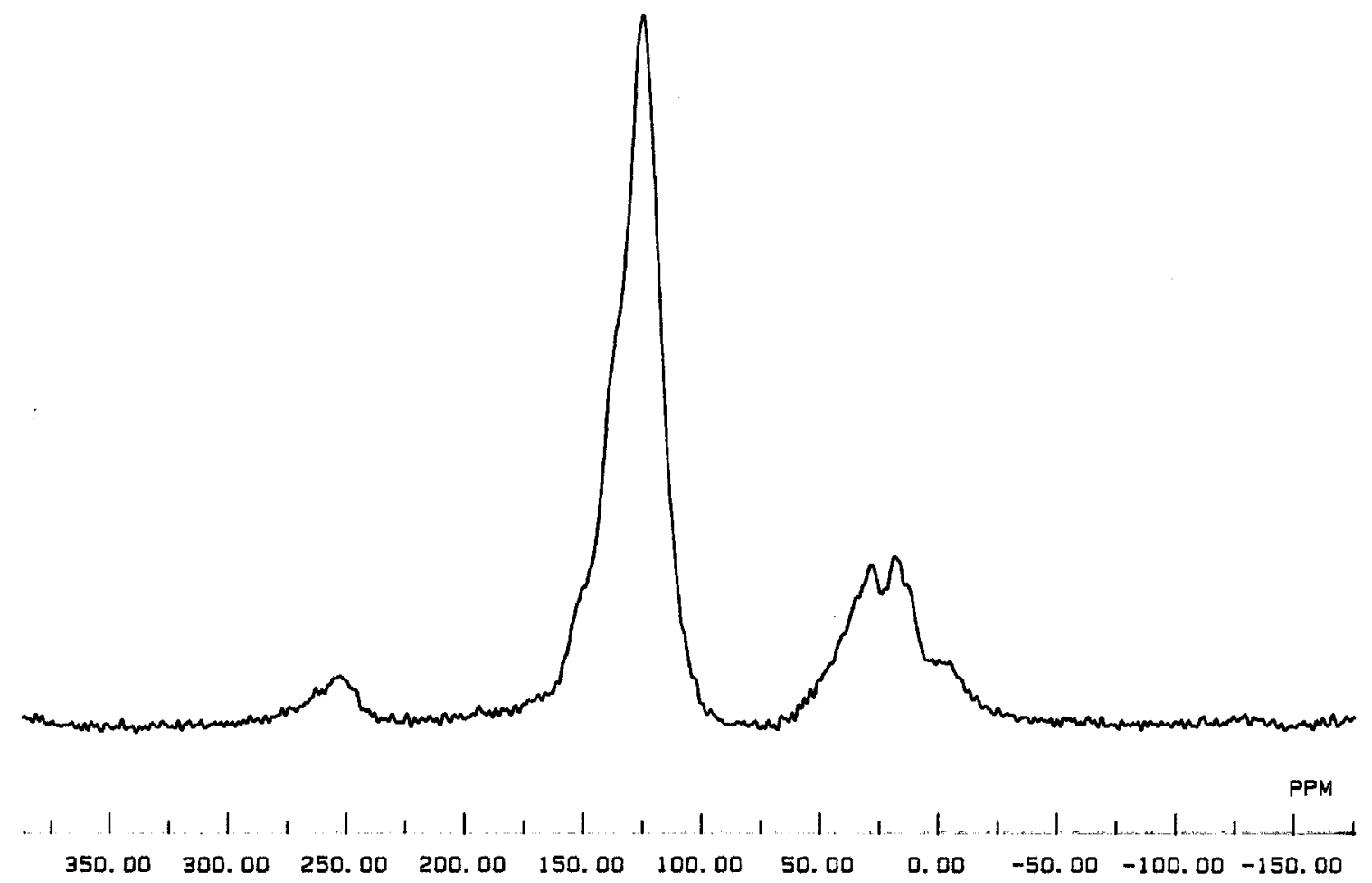

Figure 56. CPMAS NMR spectrum of DECS-30, mvb Splash Dam seam, VA.

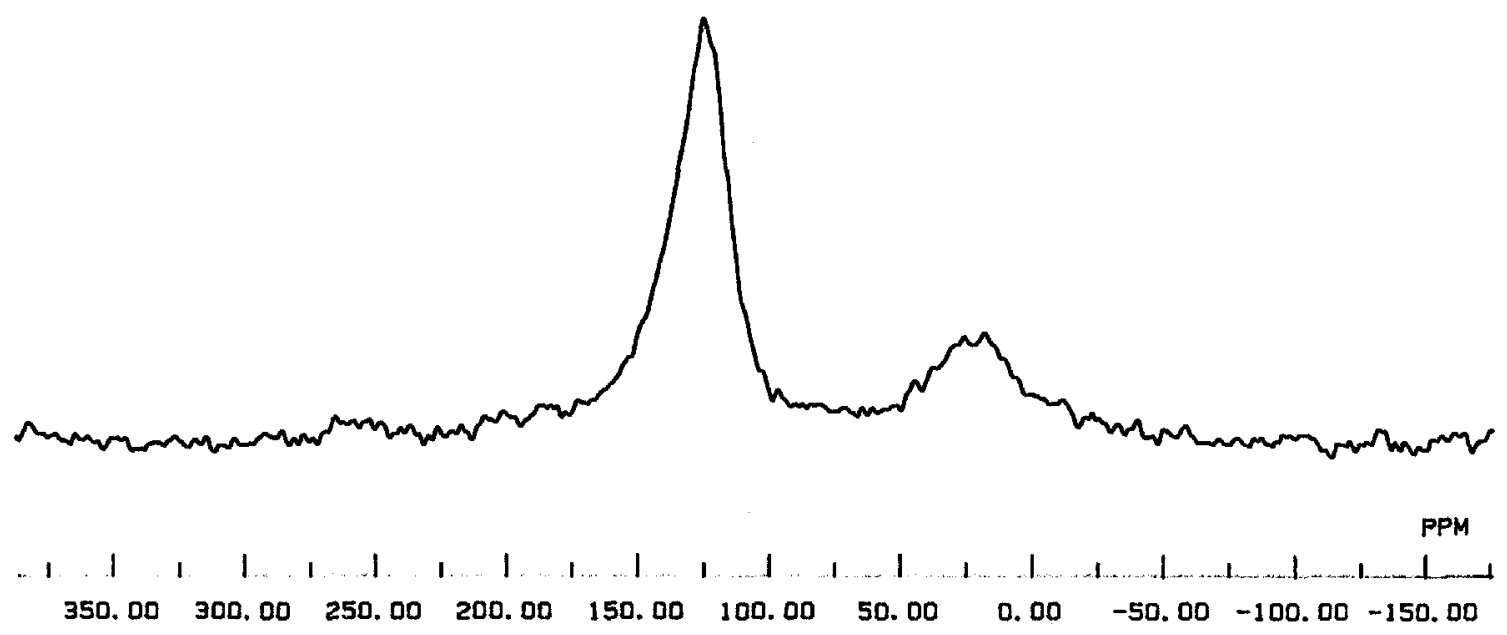

Figure 57. Bloch decay NMR spectrum of DECS-30, mvb Splash Dam seam, VA. 


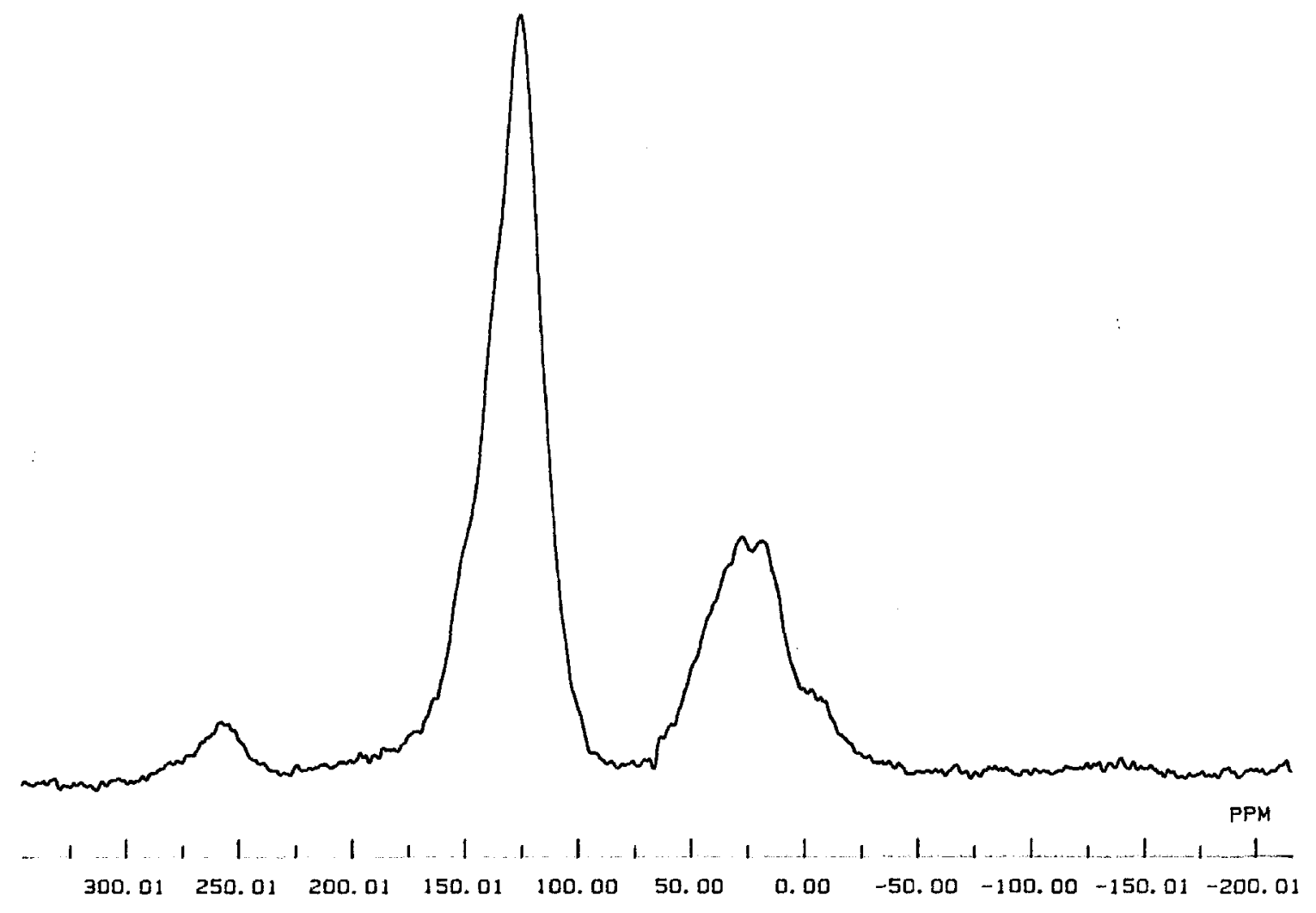

Figure 58. CPMAS NMR spectrum of DECS-31, hvAb Pond Creek seam, KY.

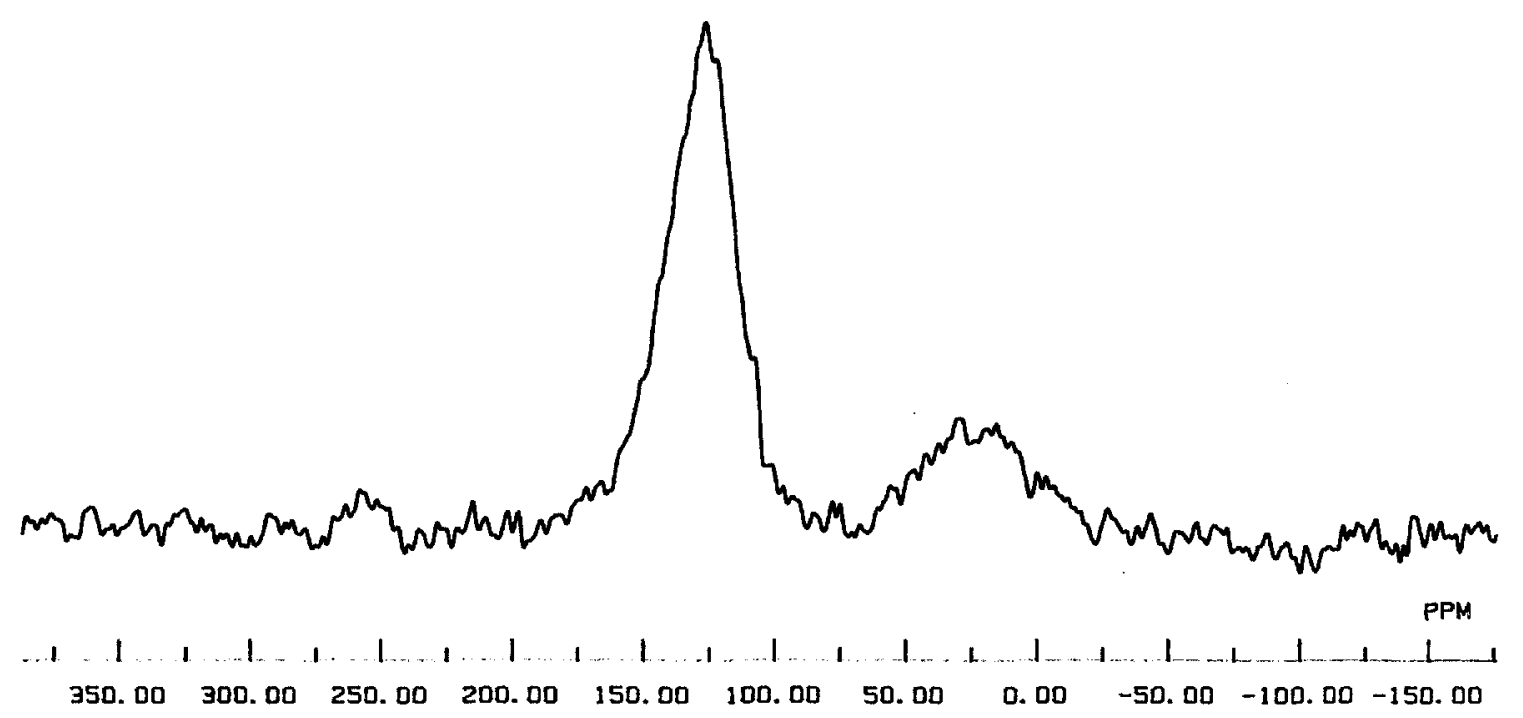

Figure 59. Bloch decay NMR spectrum of DECS-31, hvAb Pond Creek seam, KY. 


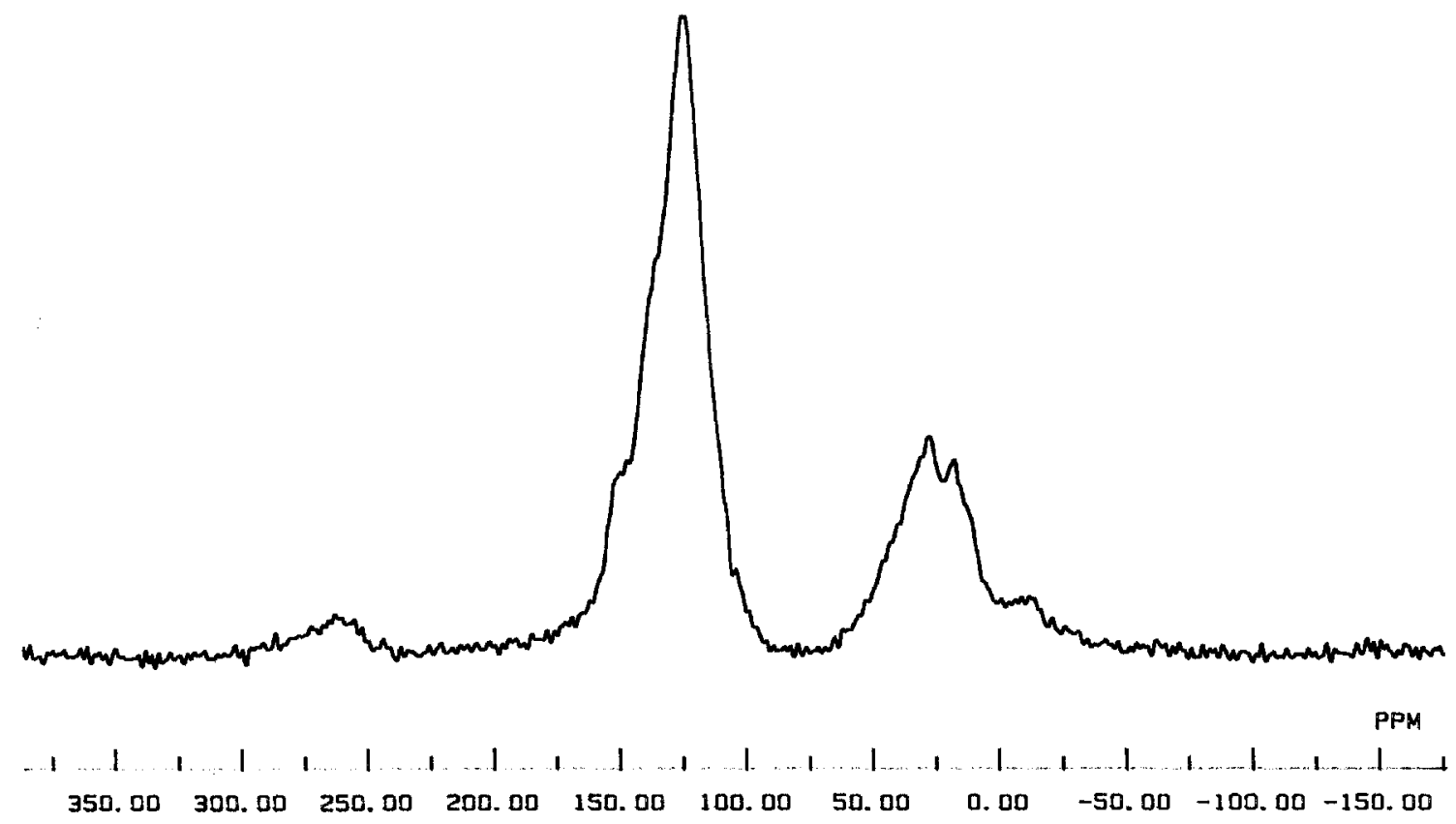

Figure 60. CPMAS NMR spectrum of DECS-32, hvAb Stockton-Lewiston seam, WV.
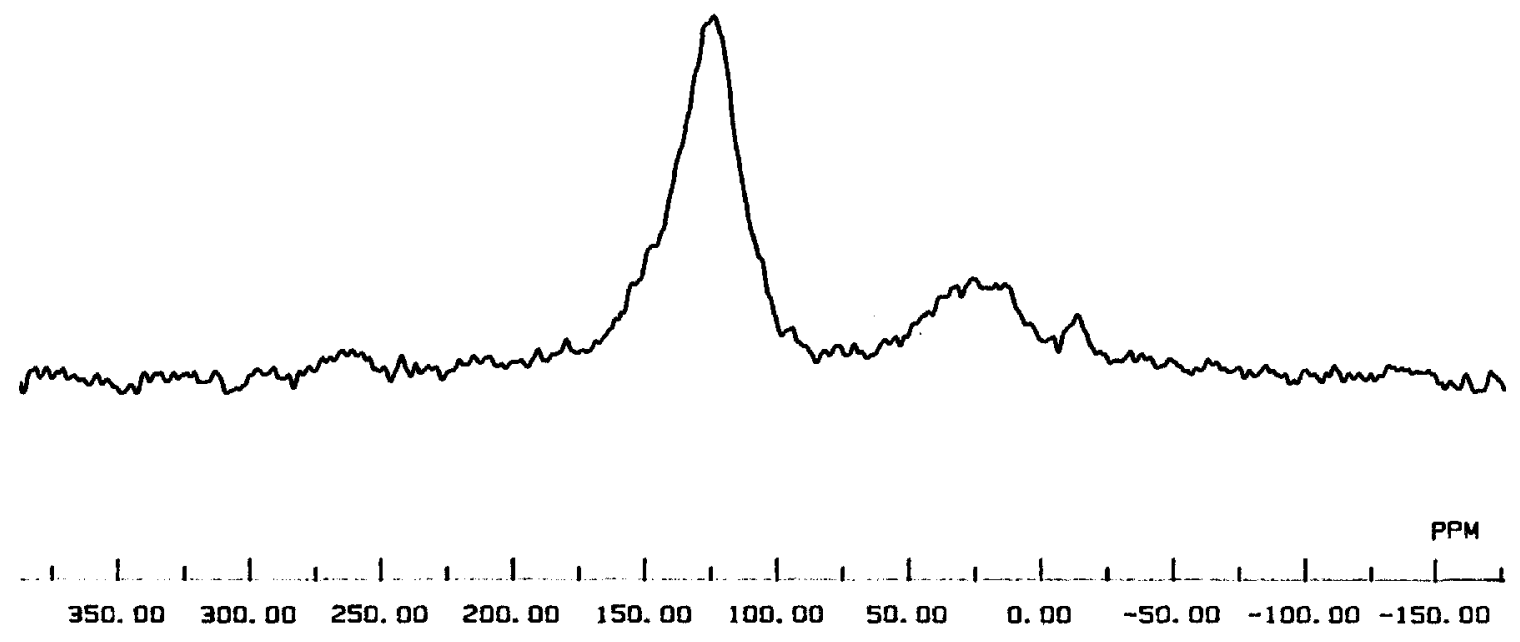

Figure 61. Bloch decay NMR spectrum of DECS-32, hvAb Stockton-Lewiston seam, WV. 


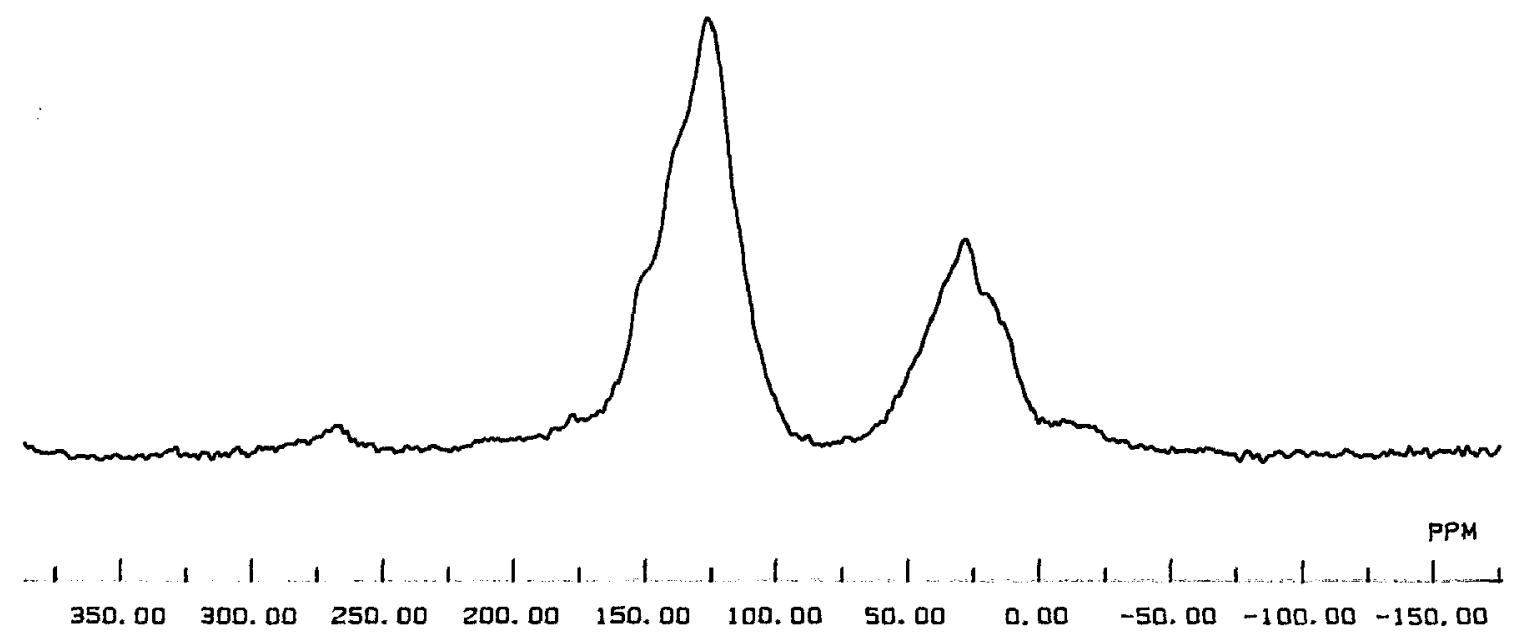

Figure 62. CPMAS NMR spectrum of DECS-33, hvBb Ohio \#4 seam, OH.

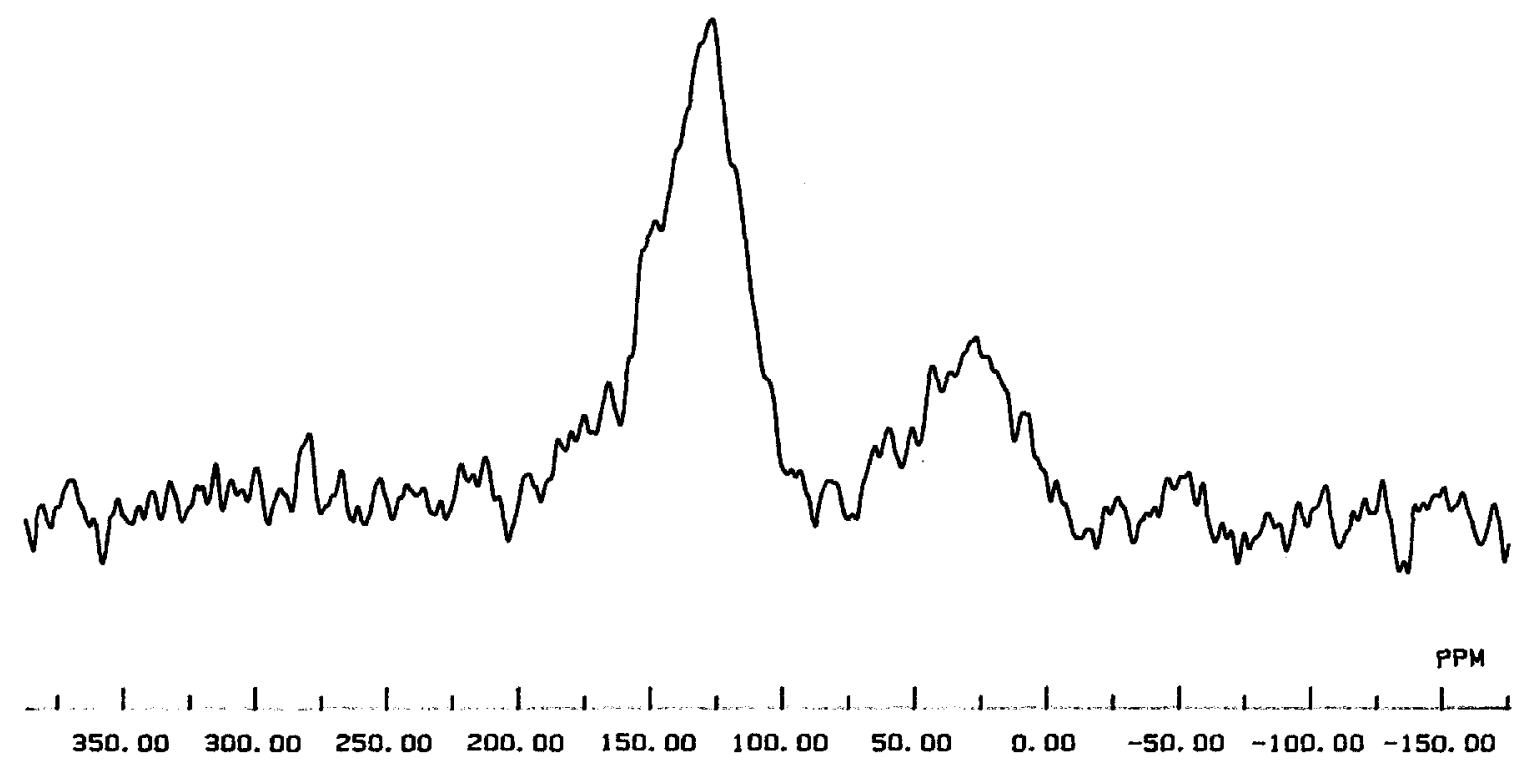

Figure 63. Bloch decay NMR spectrum of DECS-33, hvBb Ohio \#4 seam, OH. 


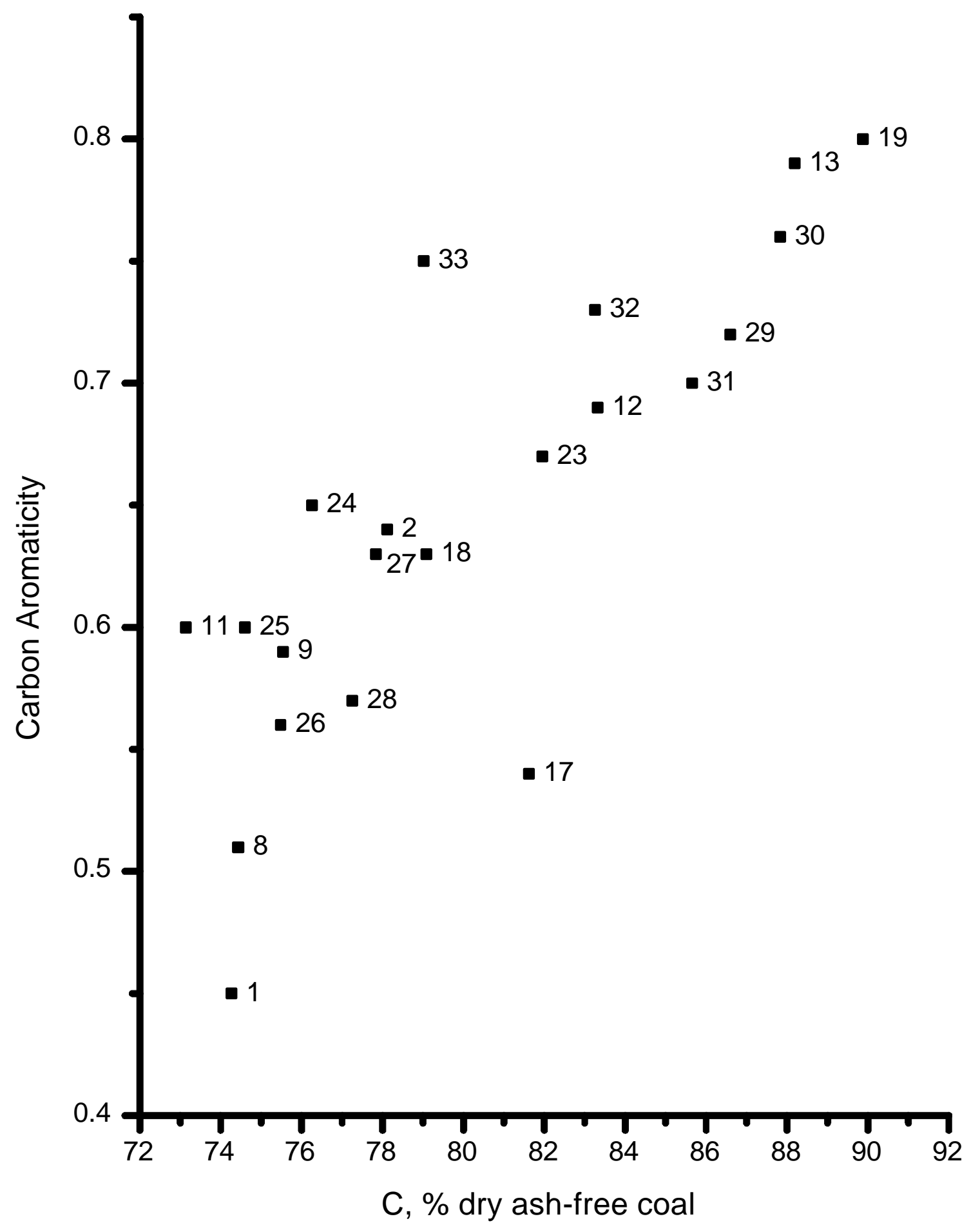

Figure 64. Carbon aromaticity vs. carbon content of dry ash-free coal for 21 DECS samples. 


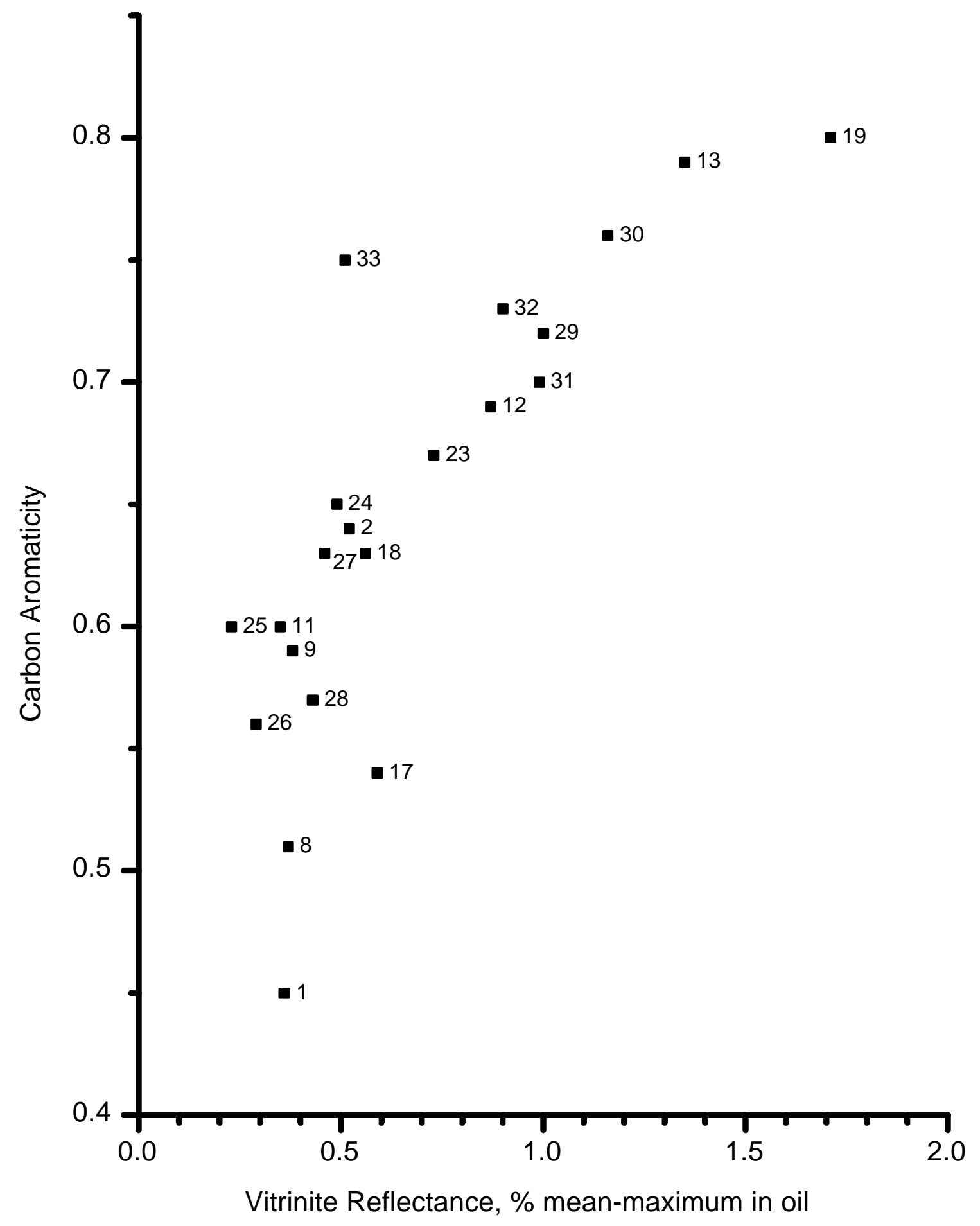

Figure 65. Carbon aromaticity vs. vitrinite reflectance for 21 DECS samples. 


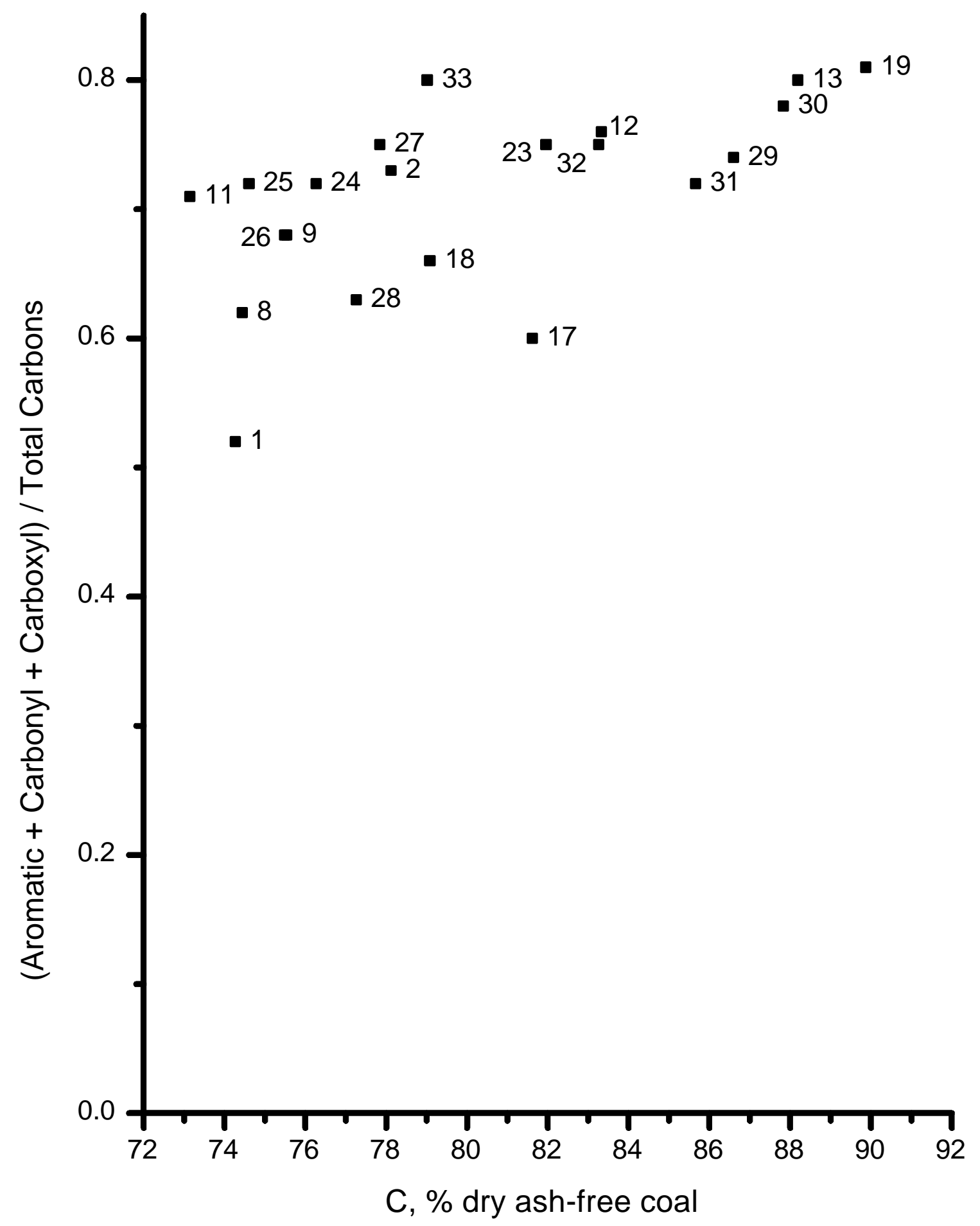

Figure 66. Aromatic + carbonyl + carboxyl fraction of total carbons vs. carbon content of dry ashfree coal for 21 DECS samples. 


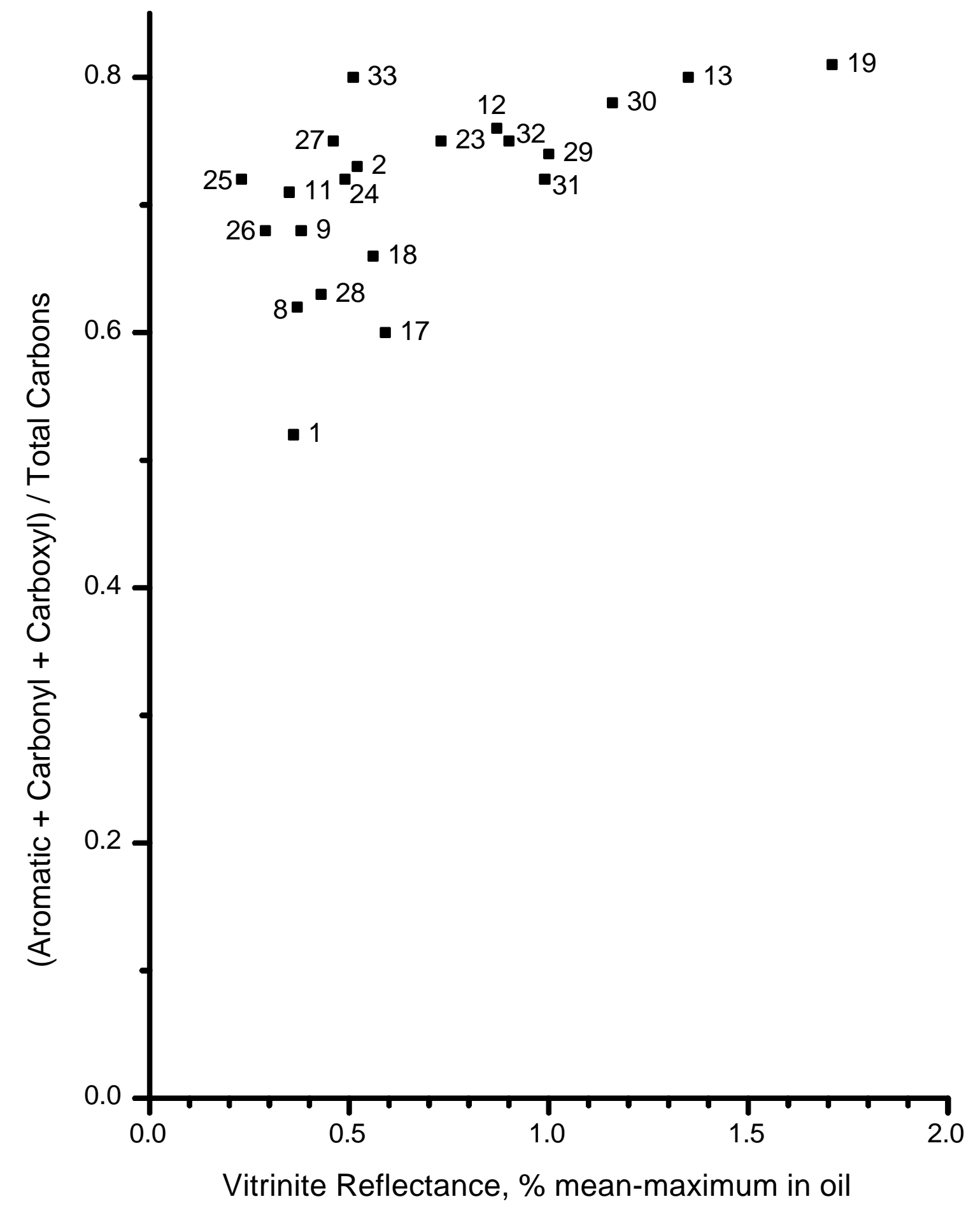

Figure 67. Aromatic + carbonyl + carboxyl fraction of total carbons vs. vitrinite reflectance of dry ash-free coal for 21 DECS samples. 


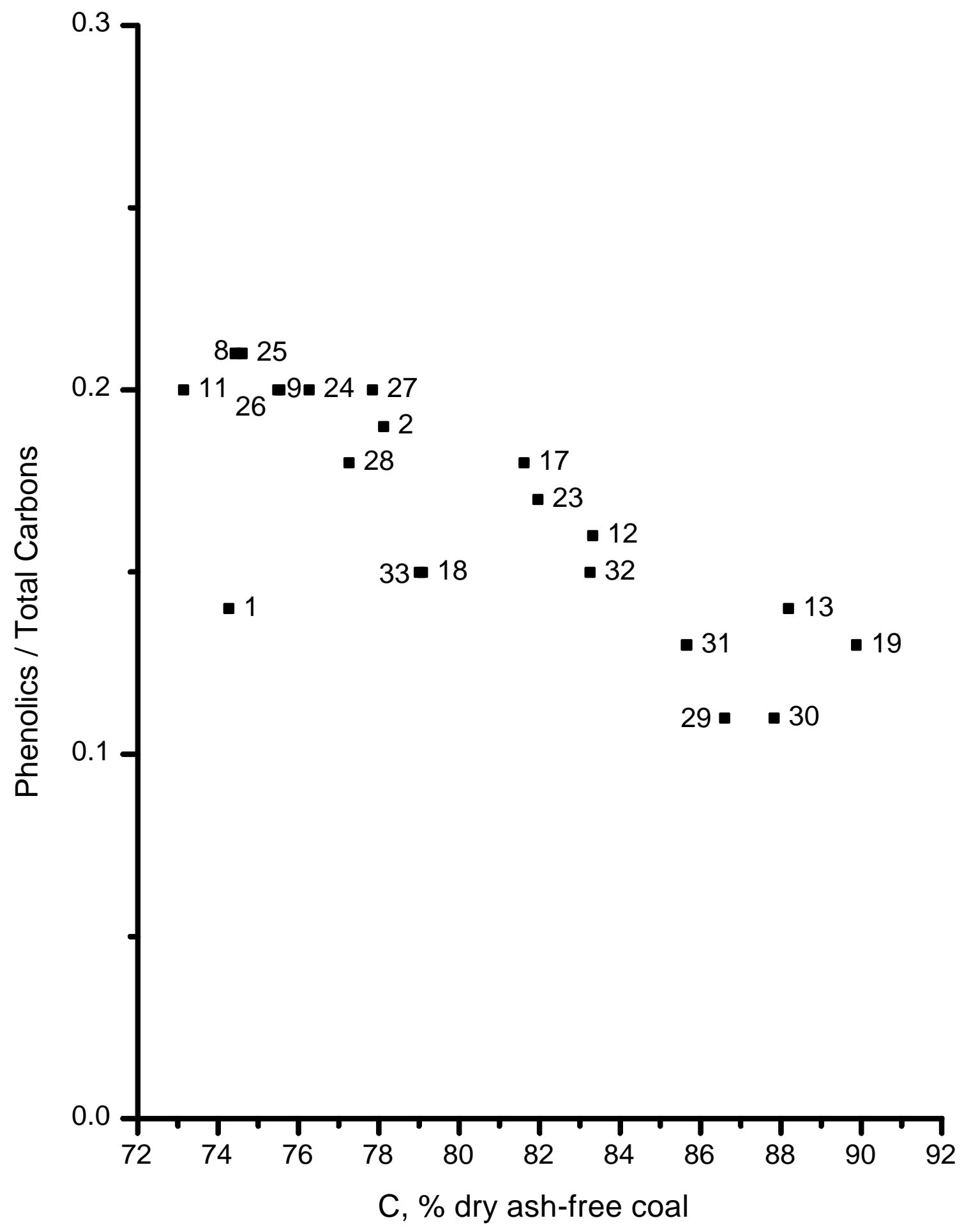

Figure 68. Phenolic fraction of total carbons vs. carbon content of dry ash-free coal for 21 DECS samples. 


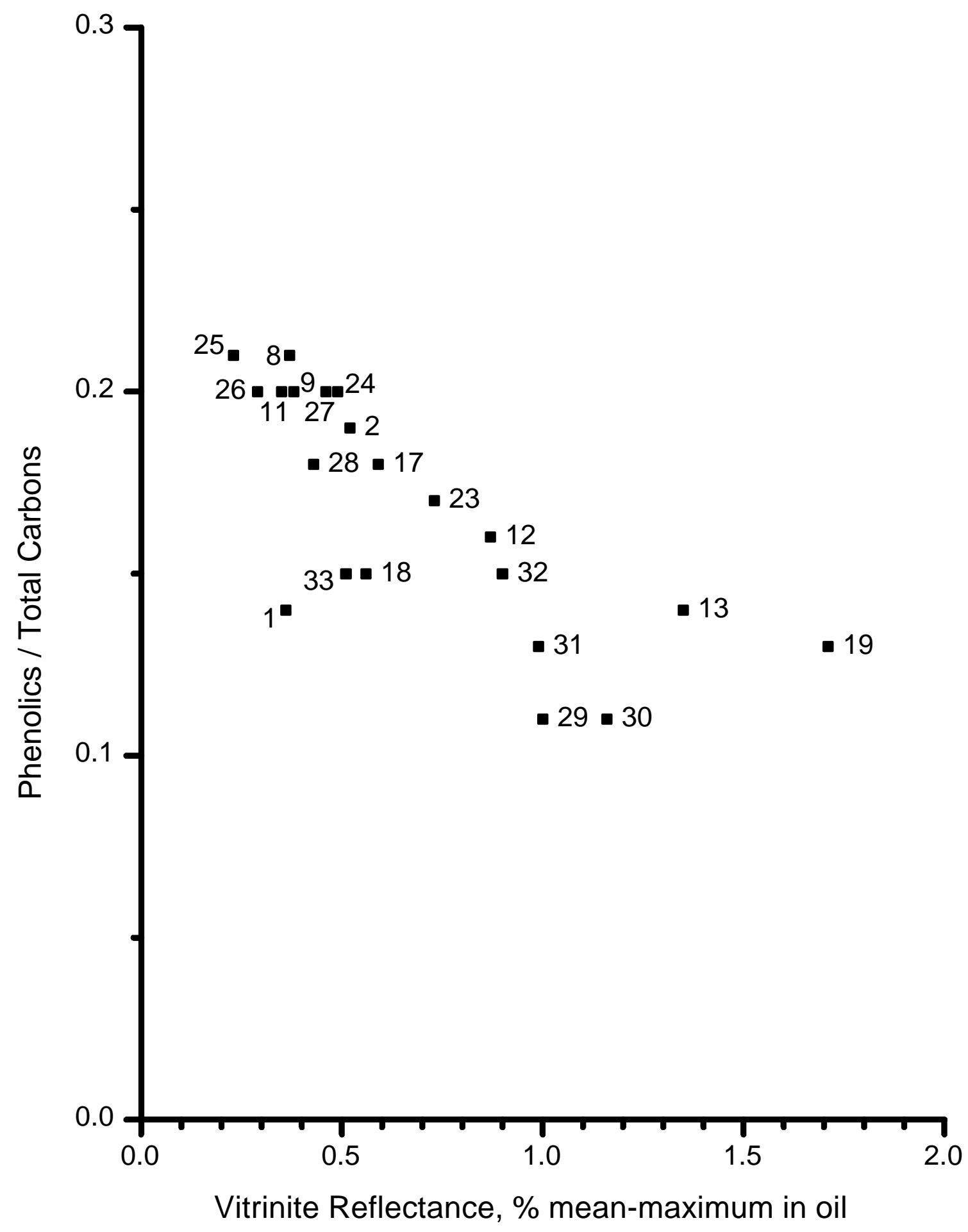

Figure 69. Phenolic fraction of total carbons vs. vitrinite reflectance of dry ash-free coal for 21 DECS samples. 


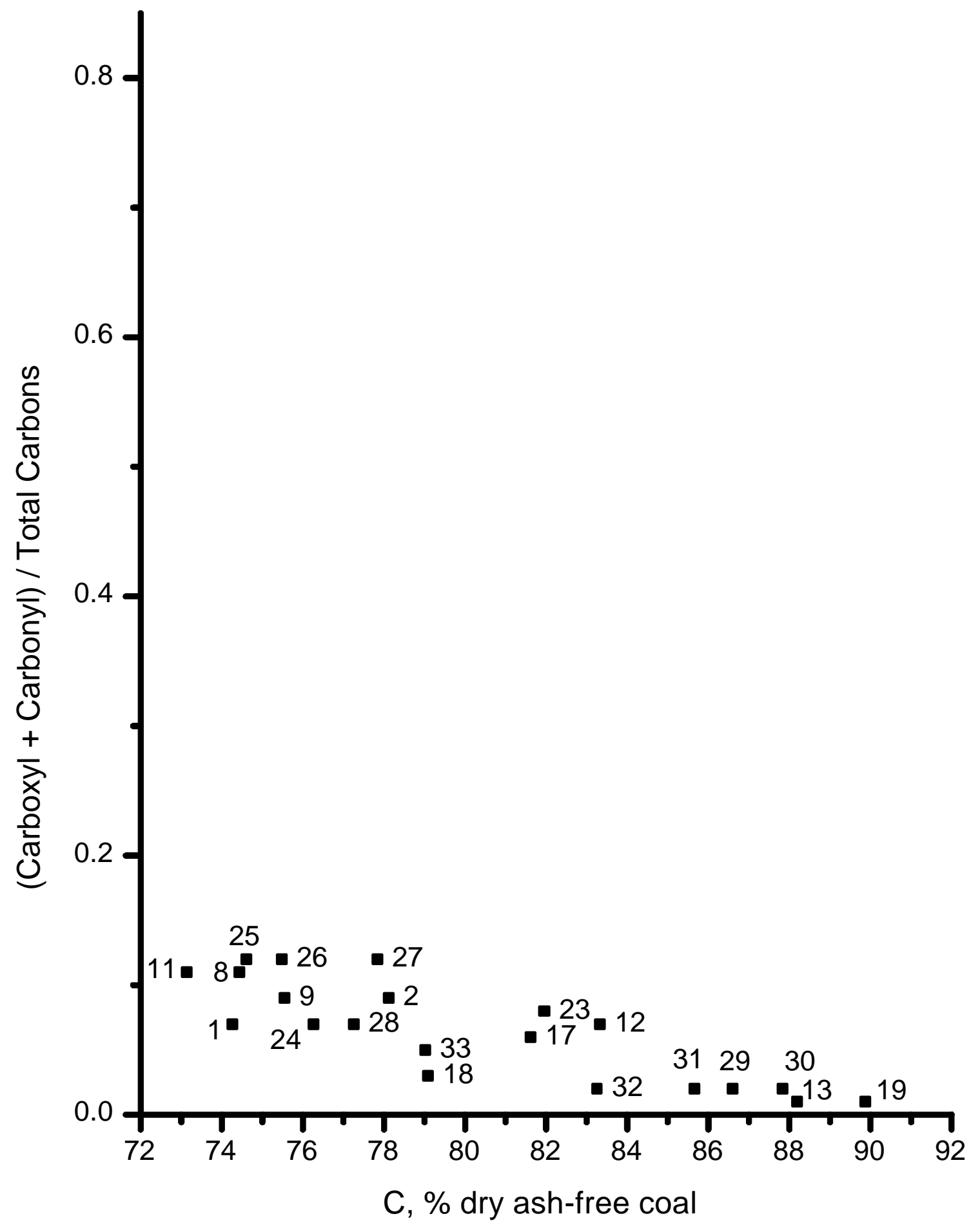

Figure 70. Carboxyl + carbonyl fraction of total carbons vs. carbon content of dry ash-free coal for 21 DECS samples 


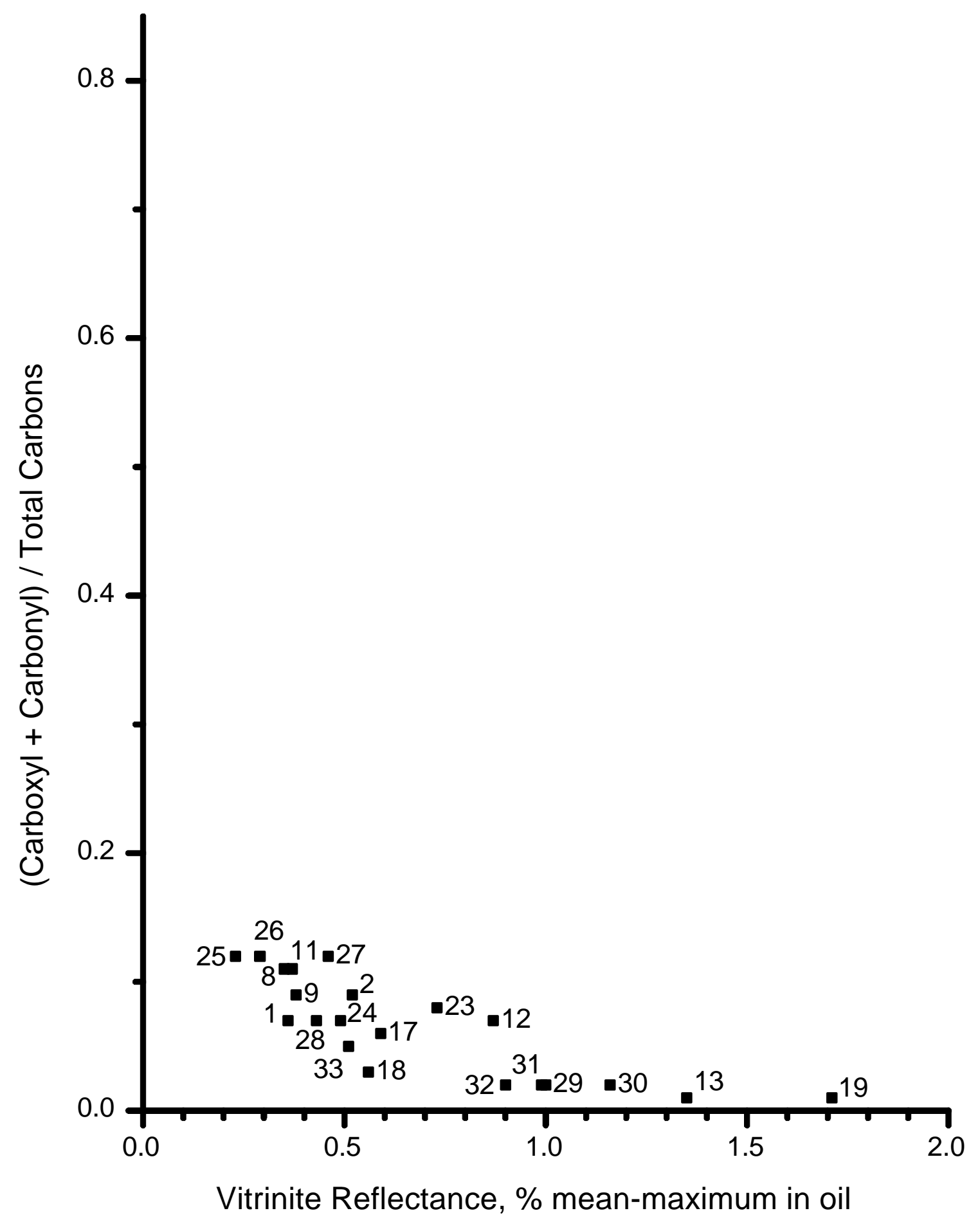

Figure 71. Carboxyl + carbonyl fraction of total carbons vs. vitrinite reflectance of dry ash-free coal for 21 DECS samples. 


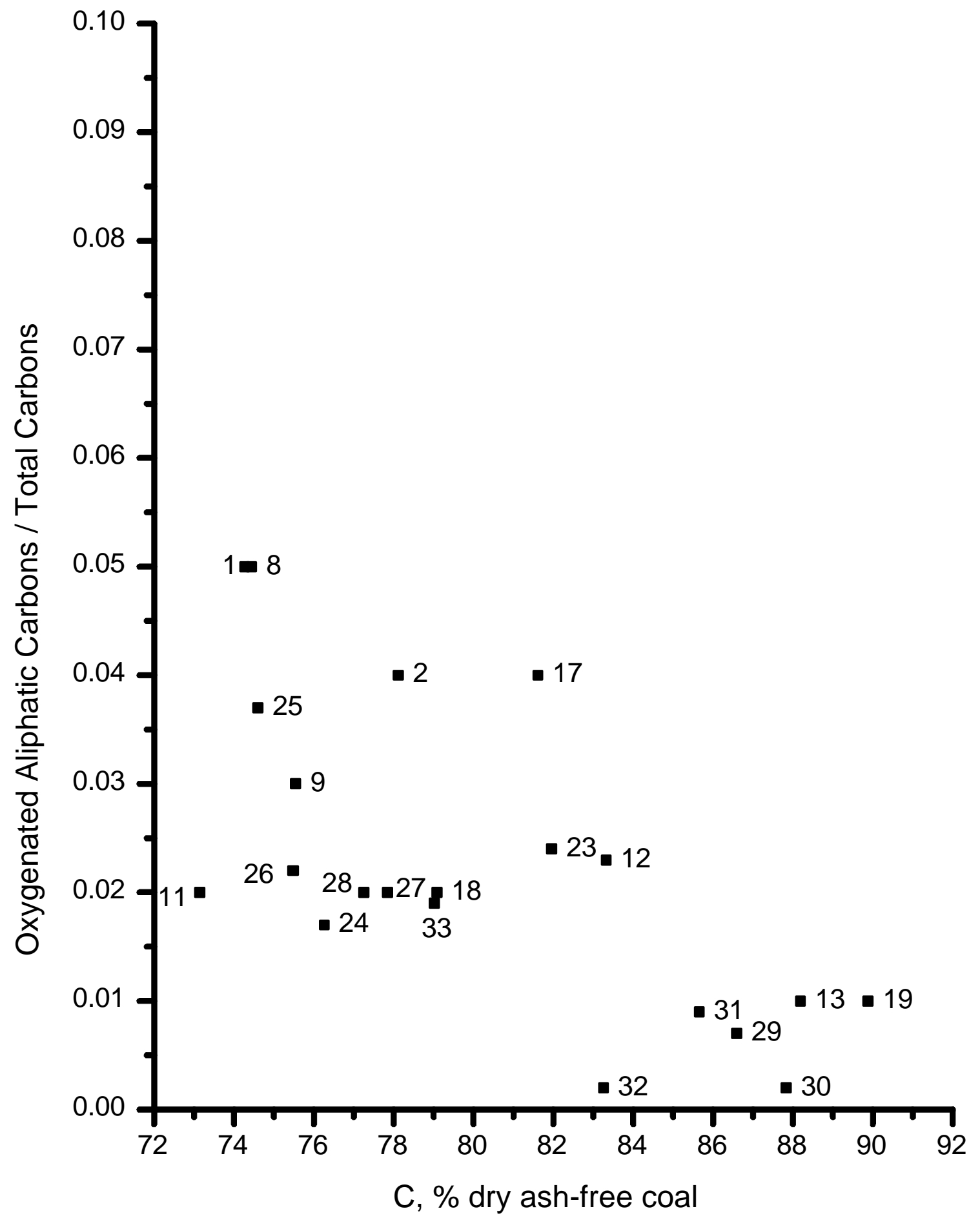

Figure 72. Oxygenated aliphatic fraction of total carbons vs. carbon content of dry ash-free coal for 21 DECS samples. 


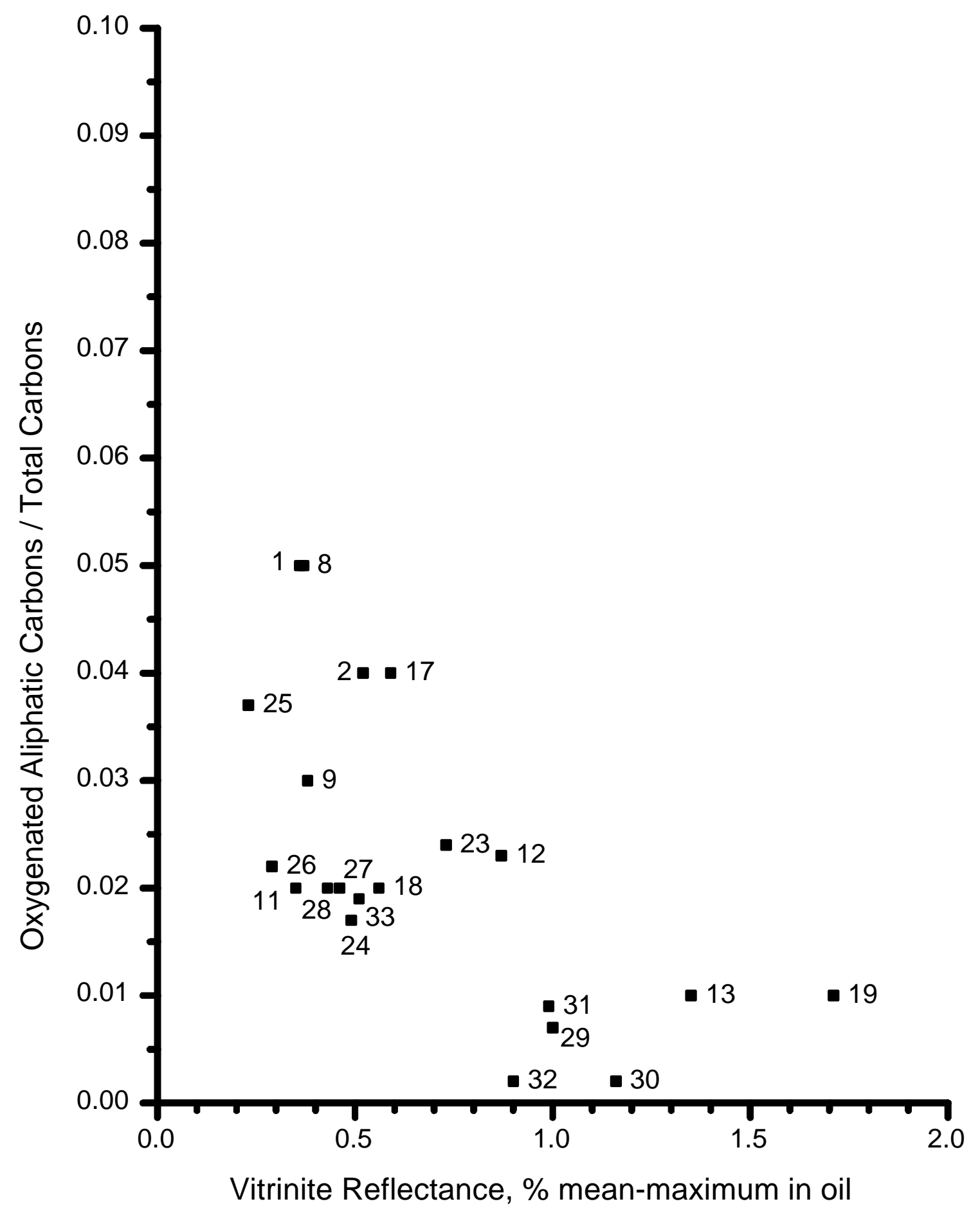

Figure 73. Oxygenated aliphatic fraction of total carbons vs. vitrinite reflectance of dry ash-free coal for 21 DECS samples. 


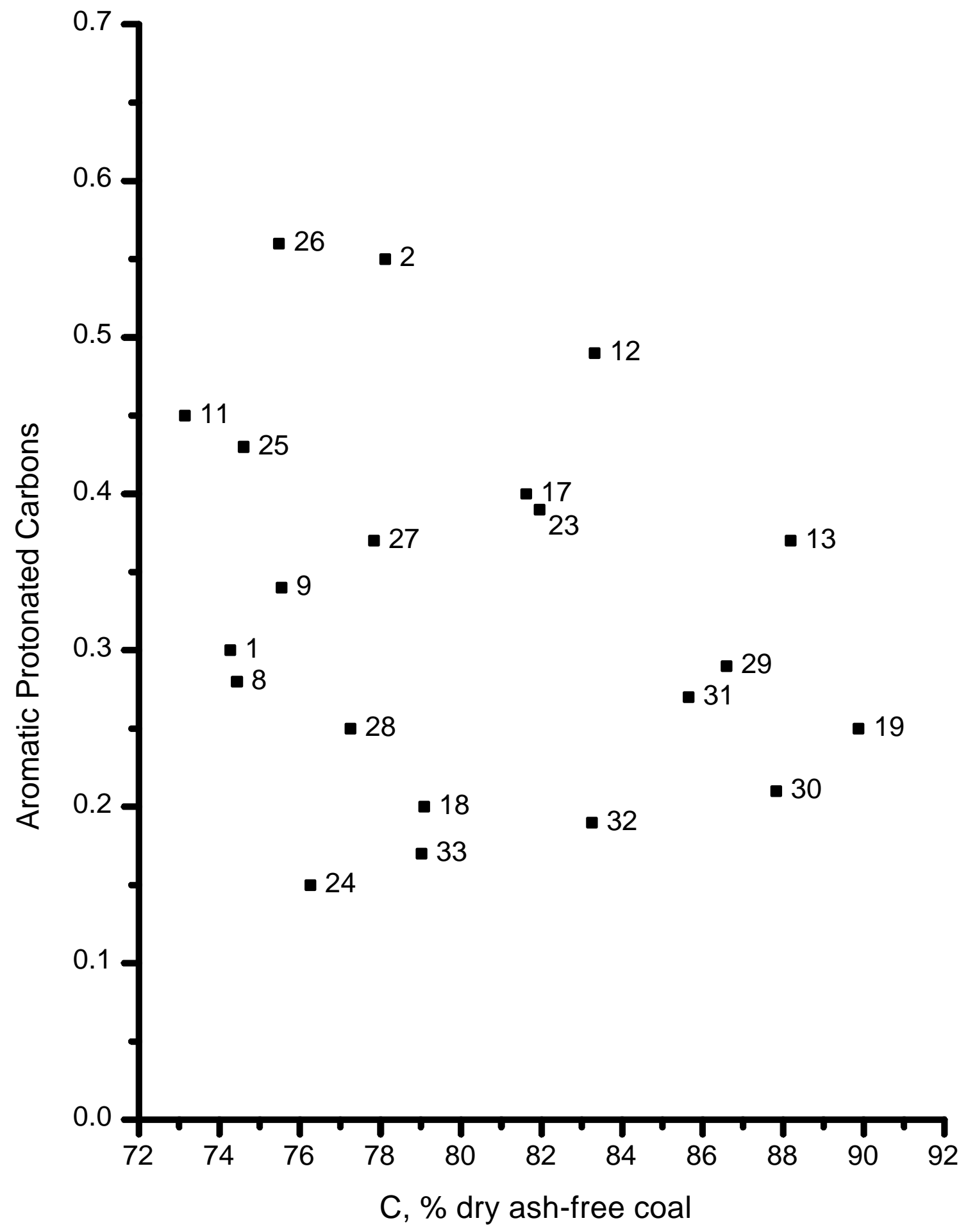

Figure 74. Aromatic protonated fraction of total carbons vs. carbon content of dry ash-free coal for 21 DECS samples 


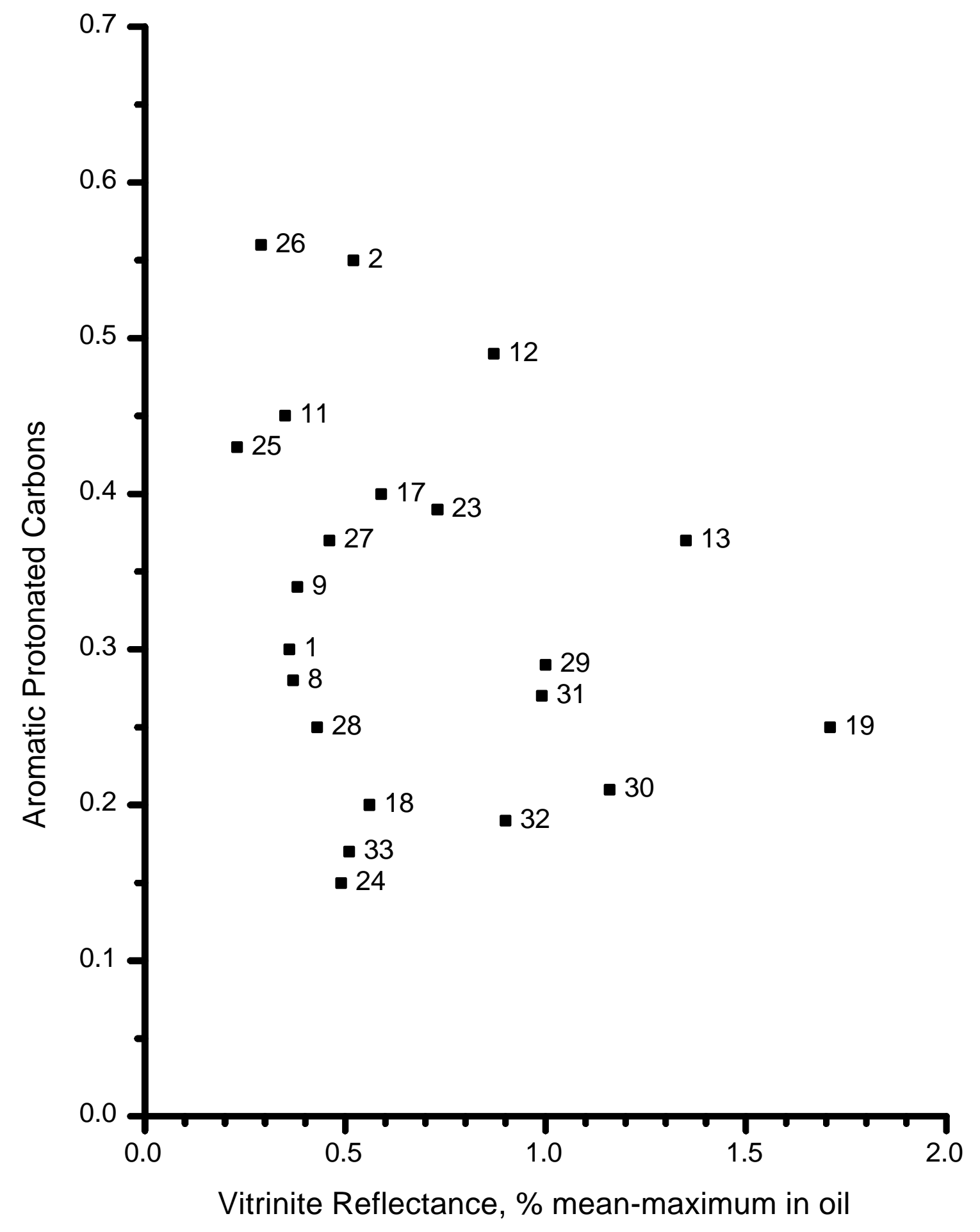

Figure 75. Aromatic protonated fraction of total carbons vs. vitrinite reflectance of dry ash-free coal for 21 DECS samples. 


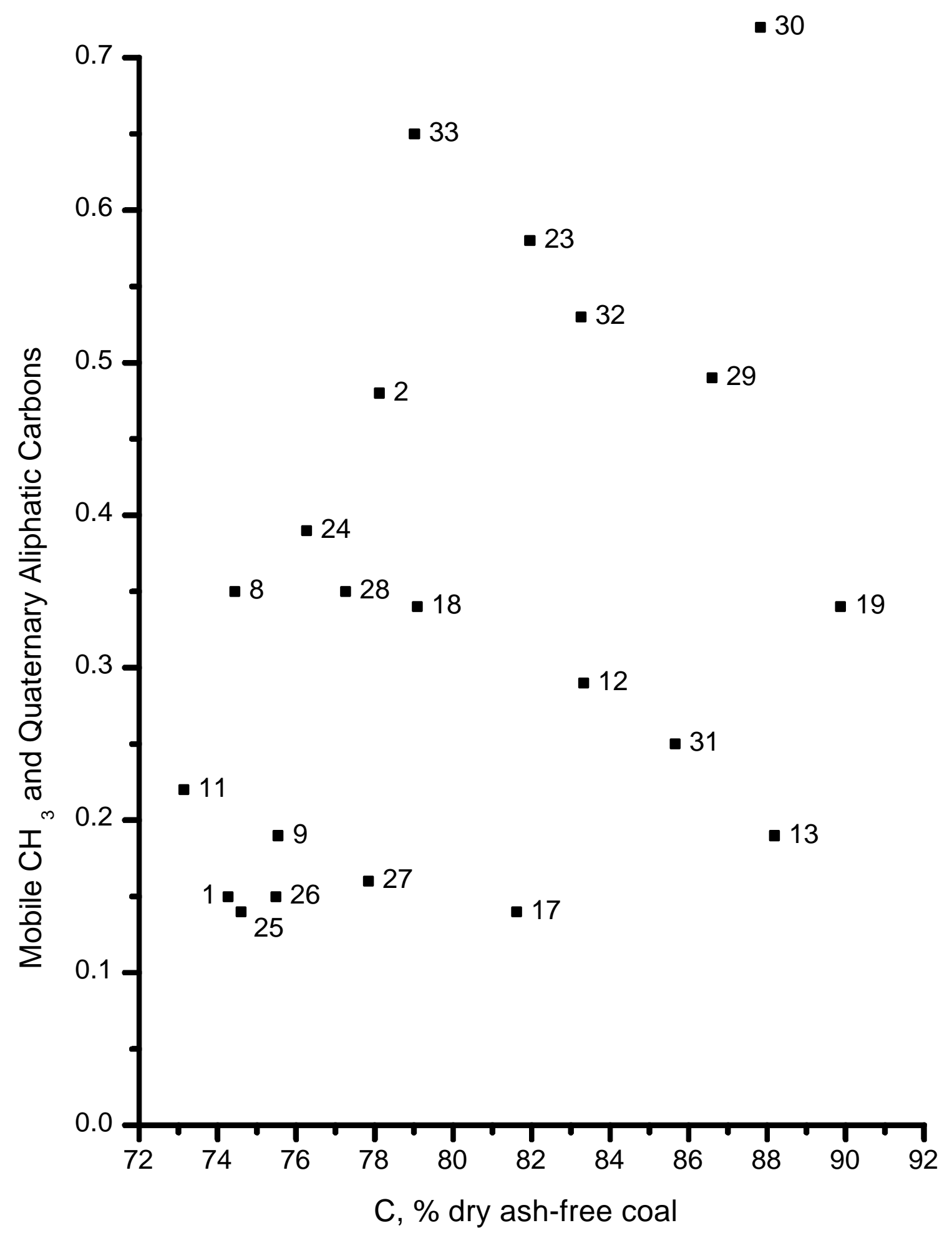

Figure 76. Mobile $\mathrm{CH}_{3}+$ quaternary aliphatic fraction of total carbons vs. carbon content of dry ash-free coal for 21 DECS samples. 


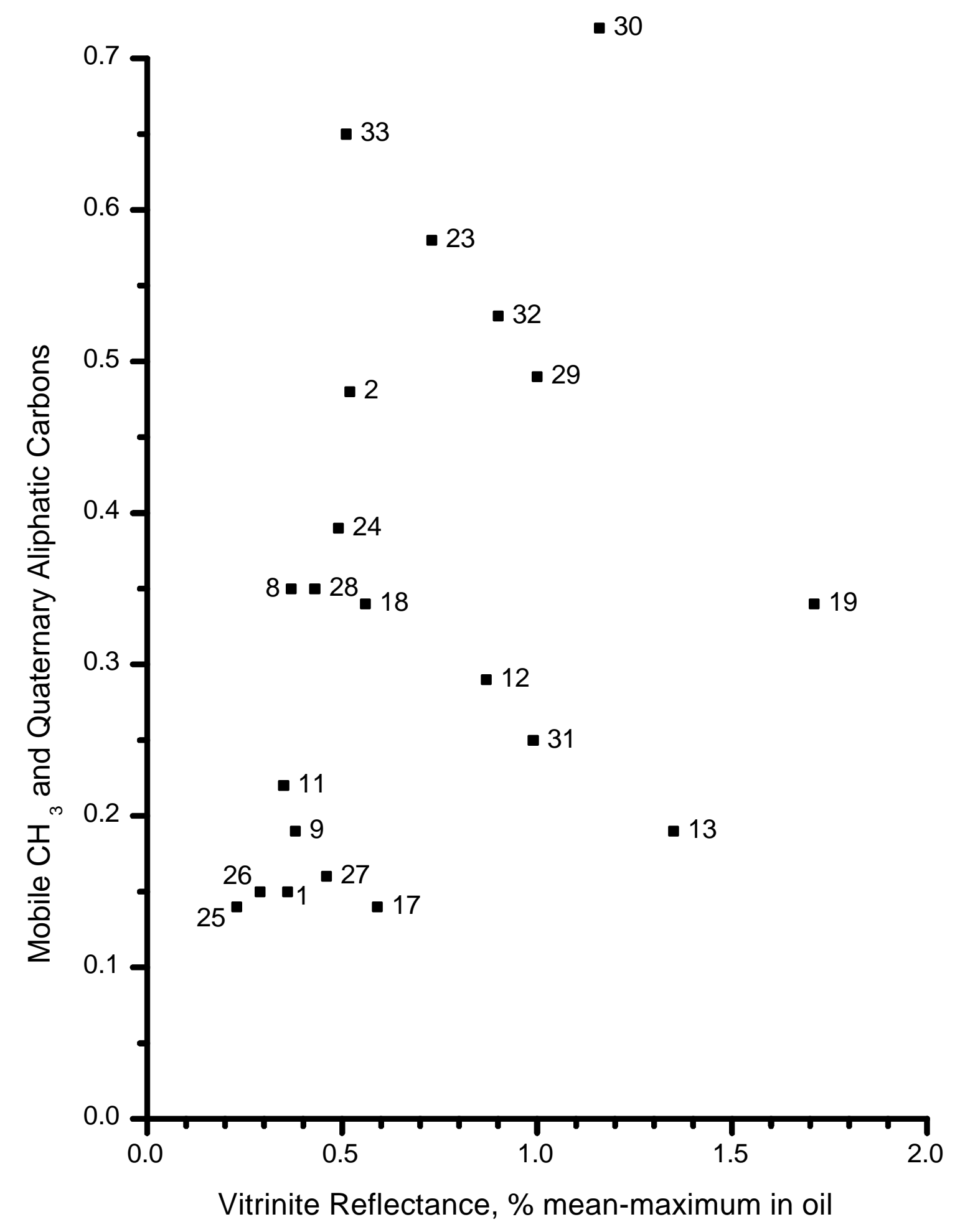

Figure 77. Mobile $\mathrm{CH}_{3}+$ quaternary aliphatic fraction of total carbons vs. vitrinite reflectance of dry ash-free coal for 21 DECS samples. 


\section{Pyrolysis - Gas Chromatography - Mass Spectrometry}

Pyrolysis/gas chromatography/mass spectrometry ( $\mathrm{py} / \mathrm{gc} / \mathrm{ms}$ ) is a technique that produces volatile thermal degradation products from coal and the products can be identified from their mass spectra after being separated by gas chromatography. Py/gc/ms is performed using a Varian 2700 gas chromatograph and a DuPont 21-490B mass spectrometer equipped with a Chemical Data Systems Pyroprobe 1000 according to the methods outlined by Hatcher et al. (1988). The pyroprobe pyrolyzes samples at any fixed heating rate ranging from 10 to $20,000^{\circ} \mathrm{C} / \mathrm{s}$ to a desired final temperature (maximum of $1400^{\circ} \mathrm{C}$ ), and holds at the final temperature for a given time $(0.01$ $99.99 \mathrm{~s}$ ). In this project a flash pyrolysis temperature of $610^{\circ} \mathrm{C}$ is employed. Lower temperatures would partially pyrolyze the sample in the probe, whereas higher temperatures produce smaller fragments of low molecular weight which would provide little structural detail and obscure the information on the exact structural features present in the sample. A heating rate of $10^{\circ} \mathrm{C} / \mathrm{ms}$ is used because relatively rapid heating minimizes the potential for secondary reactions, enhancing the detection of pyrolysis fragments characteristic of the original macromolecular, insoluble nature of the coal. The time of pyrolysis is $10 \mathrm{~s}$ to ensure complete expulsion of the volatile pyrolyzates from the capillary tube into the gas chromatograph - mass spectrometer.

It is important to carefully prepare the finely powdered sample and properly select the sample weight to minimize the effects of thermal gradients in the sample and to ensure that the representative sample is completely pyrolyzed. A sample weight of about $0.3 \mathrm{mg}$ for lignites and subbituminous coals and $0.5 \mathrm{mg}$ for higher ranks is used. Samples are weighed in a microbalance and loaded into a quartz capillary tube as evenly as possible to minimize thermal gradients. The quartz tube is placed inside the platinum heating coil of the pyroprobe; this assembly is then inserted into the injection port (temperature maintained at $280^{\circ} \mathrm{C}$ ) of a Varian 2700 gas chromatograph and the sample is pyrolyzed. The pyrolyzate is cryotrapped with liquid nitrogen prior to being subjected to gas chromatography on a J\&W DB-17 capillary column ( $25 \mathrm{~m}$ in length, $0.25 \mathrm{~mm}$ in diameter, made of $50 \%$ phenyl methyl silicone). The chromatograph temperature is programmed from $30^{\circ} \mathrm{C}(0 \mathrm{~min})$ to $280^{\circ} \mathrm{C}(20 \mathrm{~min})$ at a rate of $4^{\circ} \mathrm{C} / \mathrm{min}$. The effluent was swept into the source of a DuPont 21-490B mass spectrometer fitted with a Teknivent Vector/One data system for detection and compound identification. Compounds are identified by a combination of methods including comparison of mass spectra to the NBS/Wiley library and other published mass spectra and to authentic standards. This $\mathrm{py} / \mathrm{gc} / \mathrm{ms}$ technique has been found to be very reproducible for repetitive analysis of the same sample.

\section{Results}

Pyrograms produced from each of the DECS samples are shown in Figures 78-98. From these traces, peaks can be identified and grouped into compound classes (e.g., n-alkanes-group 1, phenols-group 2, and non-oxygenated aromatic hydrocarbons-group 3). The yields of each group (peak areas) normalized to the total areas of all peaks are shown in Table 9. Often, many peaks remain unidentified and these are also tabulated. One usually normalizes the summed areas of compound classes relative to the total area of identified peaks and these data are shown in Table 10. The inability to identify peaks is usually not due to the lack of spectral recognition but rather 
to the fact that so many peaks are overlapping in certain regions of the chromatograms that it is difficult to make a positive identification. Often, co-elution of peaks renders quantitative measurements difficult.

As one progresses from low-rank coals to the higher rank samples, a transition is observed as the highly phenolic (in most instances) content of the low rank samples gives way to the non-oxygenated aromatic-dominated coals. This trend is generally observed by plotting the yields of non-oxygenated aromatics with rank in Figures 99 and 100. Samples DECS-29, 30, and 13 do not appear to follow this trend. Examination of the pyrograms reveals that these samples contain n-alkanes in overabundance for their high rank. This could be indicative that oil or petroleum hydrocarbons may have migrated into the samples. This coupled with the fact that high rank coals usually do not produce significant amounts of pyrolysis products explains the low yield of non-oxygenated aromatic products. If one examines the correlation in Figure 100 ignoring the data for these samples, then an excellent trend is observed.

Plots of the yields of n-alkanes and alkenes (Figures 101 and 102) show no correlation with rank. If one ignores the aforementioned samples DECS-13, 29 and 30, then a better correlation with Ro is observed in Figure 102.

The best correlations are observed between phenolic contents and rank (Figures 103 and 104), especially if one ignores DECS-1, which is dominated by an homologous series of n-alkanes and alkenes as would be found for liptinitic macerals. The high yields of alkanes and alkenes reduces the phenolic content for this sample. The diminishing yields of phenolic pyrolysis products as rank increases is consistent with the known diminution of phenolics. The NMR data also showed a similar trend. Thus the py/gc/ms data are very well in tune with the NMR data for this series of coals.

The data presented in this final report indicate that there are some correlations among the data sets which could be examined in greater detail. The project goals for this part of the work were to provide the analytical results, a goal completed and demonstrated by the large amounts of data that were obtained. Preliminary correlations among the data sets gave indications that more information is available upon closer examination. The highlighted trends show typical behavior expected for most coals. A number of the outliers from the trends shown can be explained based on the maceral compositions or other known properties of the various coals. Further investigation of the data could be performed under a subsequent contract. 


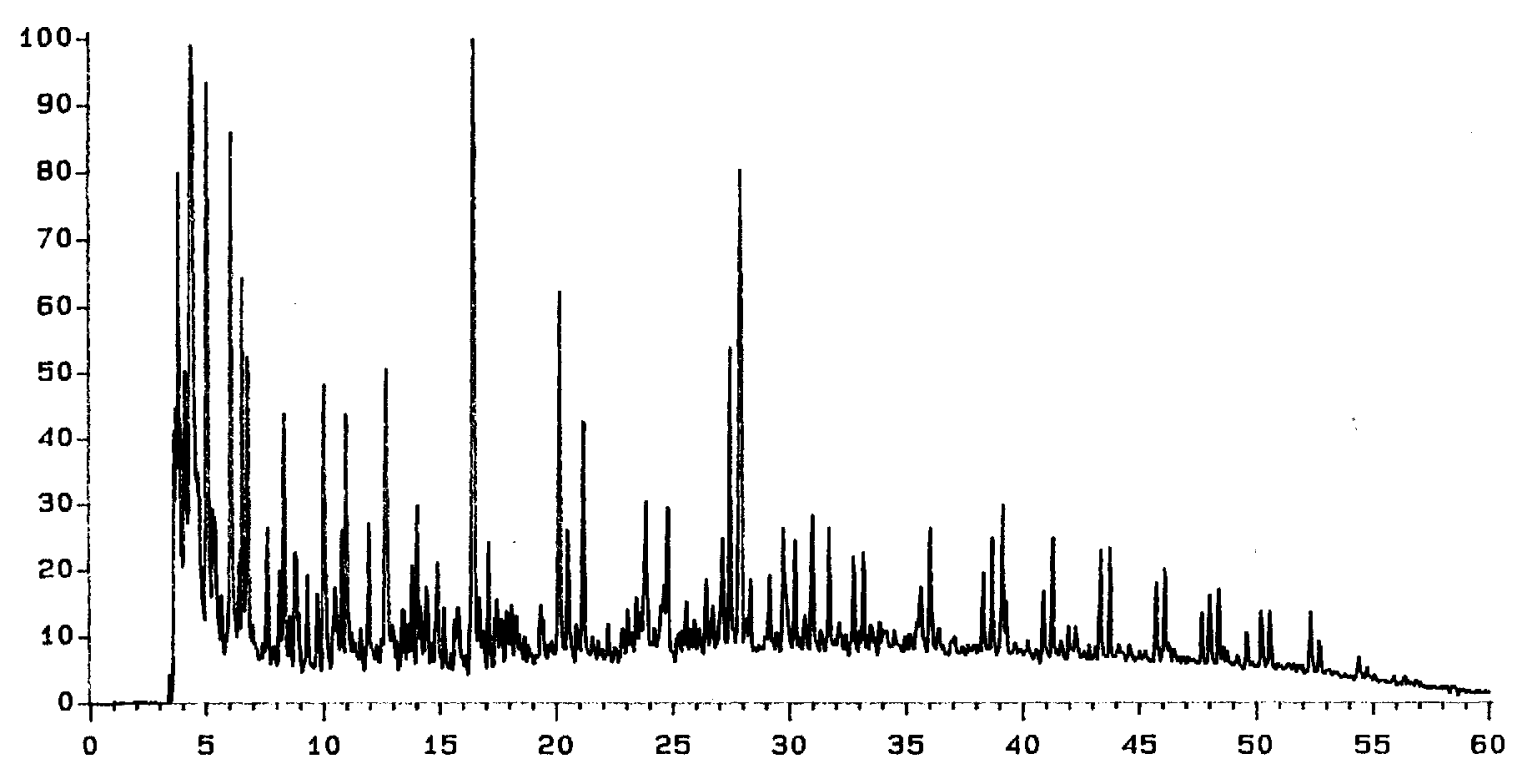

Figure 78. Total ion chromatogram of pyrolyzates from DECS-1, subC Bottom seam, TX.

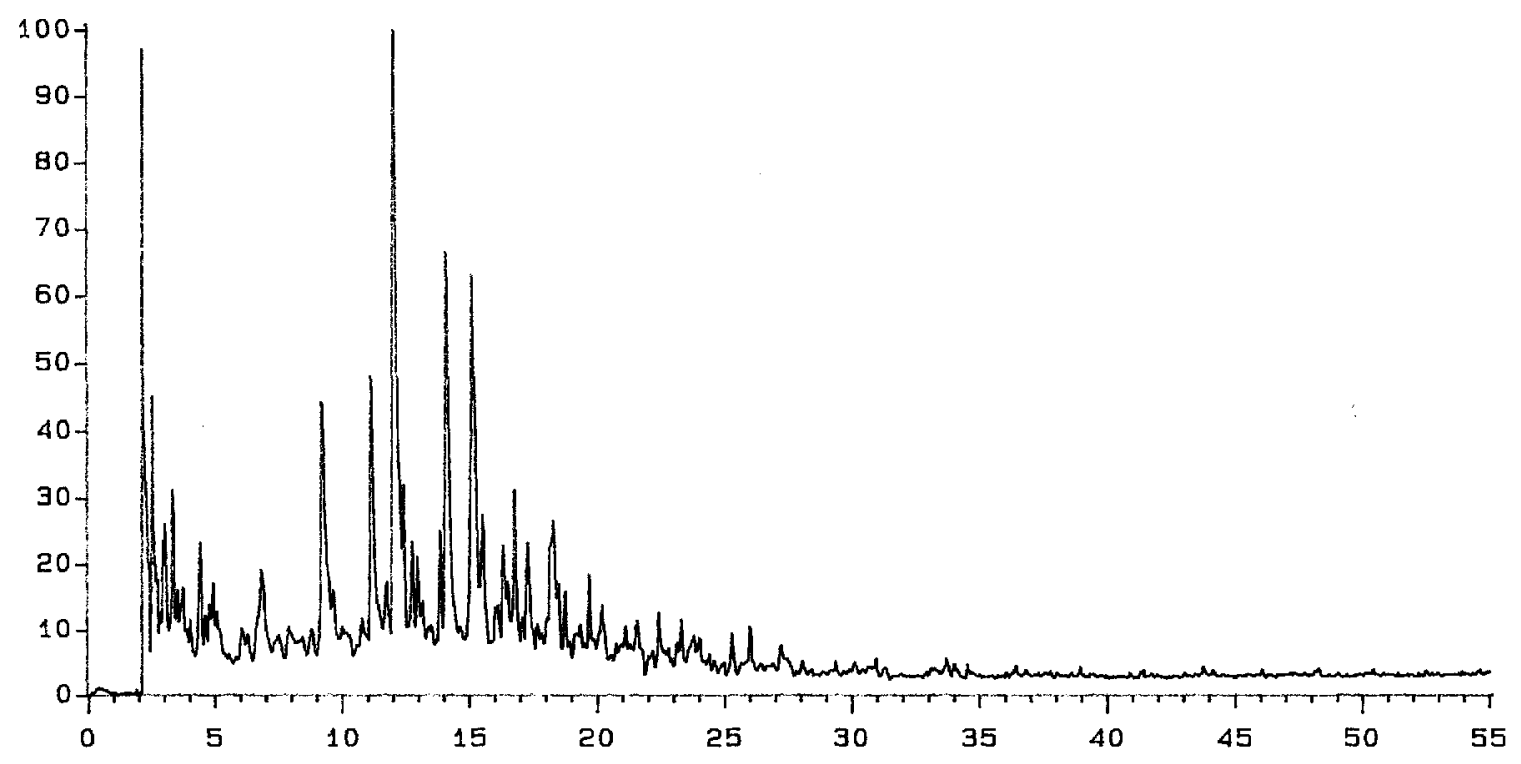

Figure 79. Total ion chromatogram of pyrolyzates from DECS-2, hvCb Illinois \#6 seam, IL. 


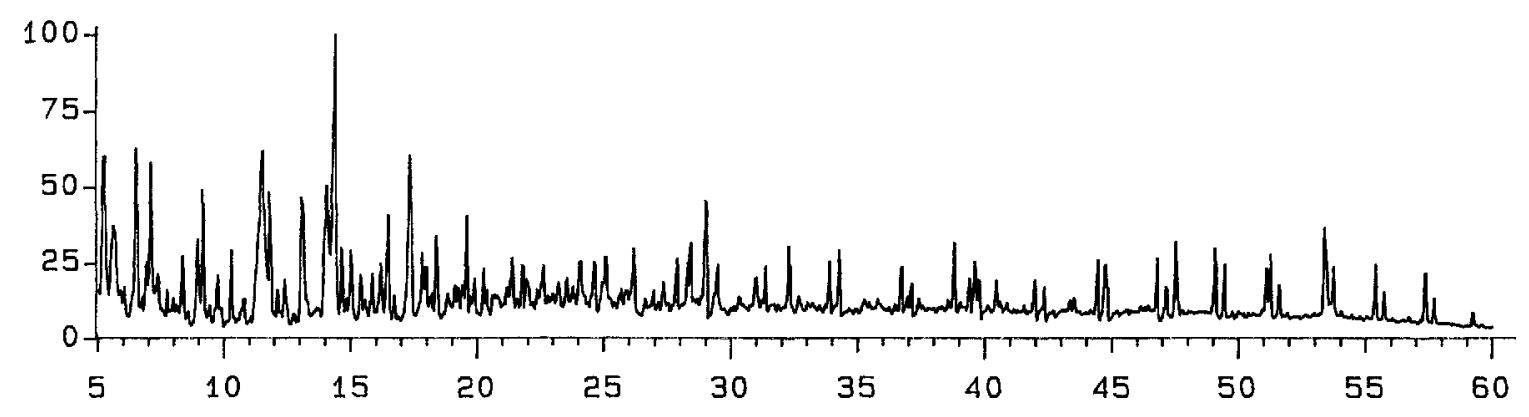

Figure 80. Total ion chromatogram of pyrolyzates from DECS-8, subC Smith-Roland ("Wyodak") seam, WY.

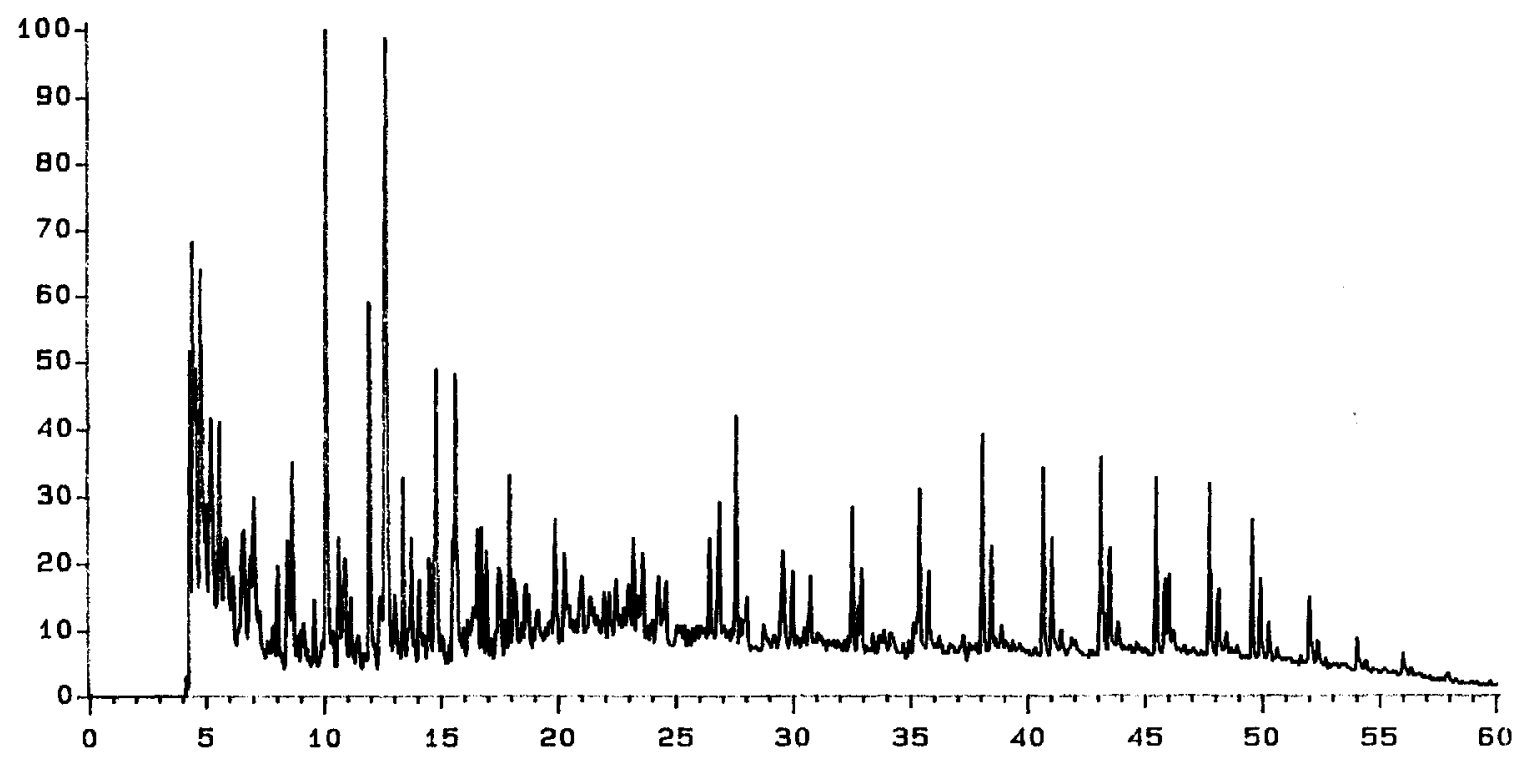

Figure 81. Total ion chromatogram of pyrolyzates from DECS-9, subB Dietz seam, MT. 


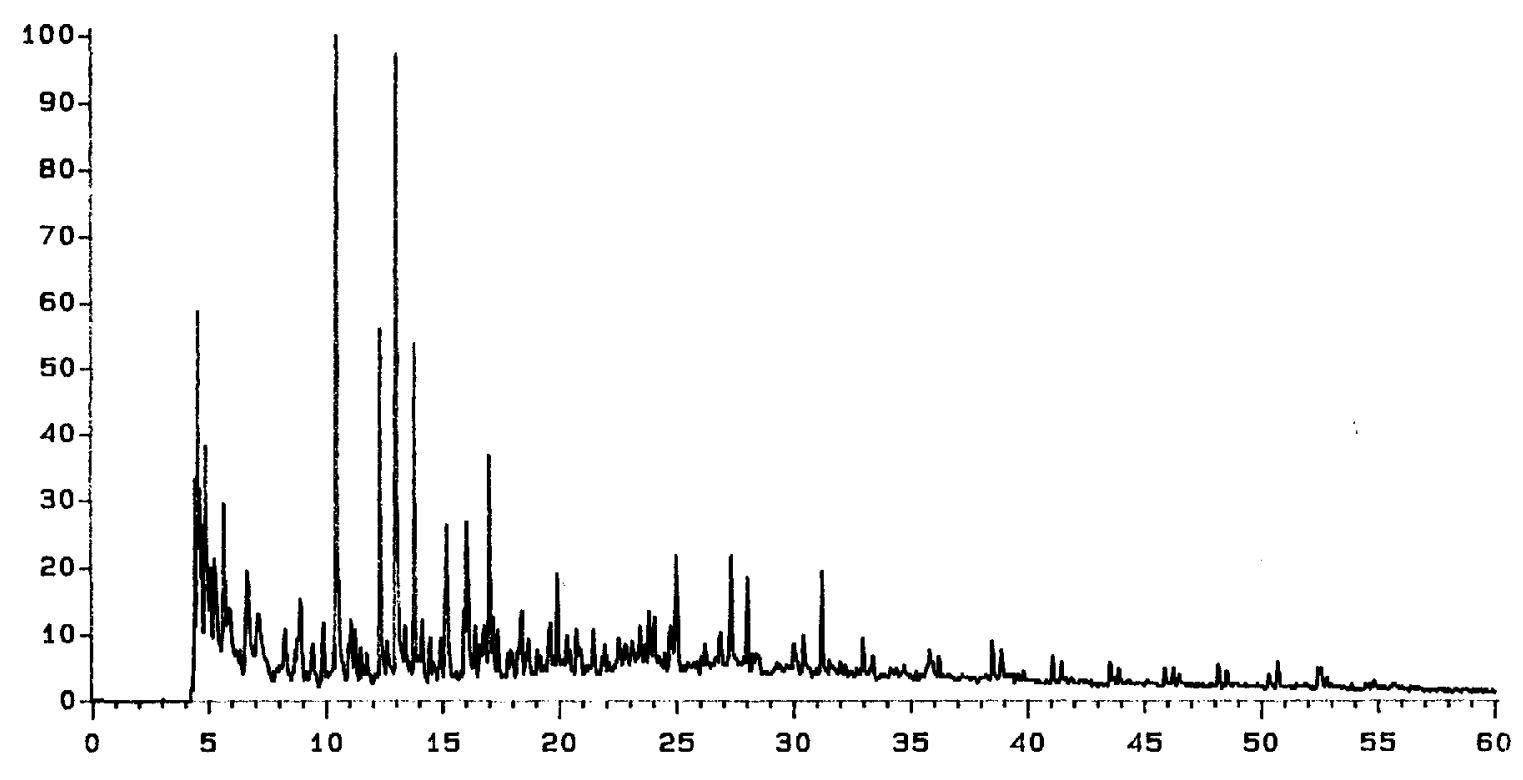

Figure 82. Total ion chromatogram of pyrolyzates from DECS-11, ligA Beulah seam, ND.

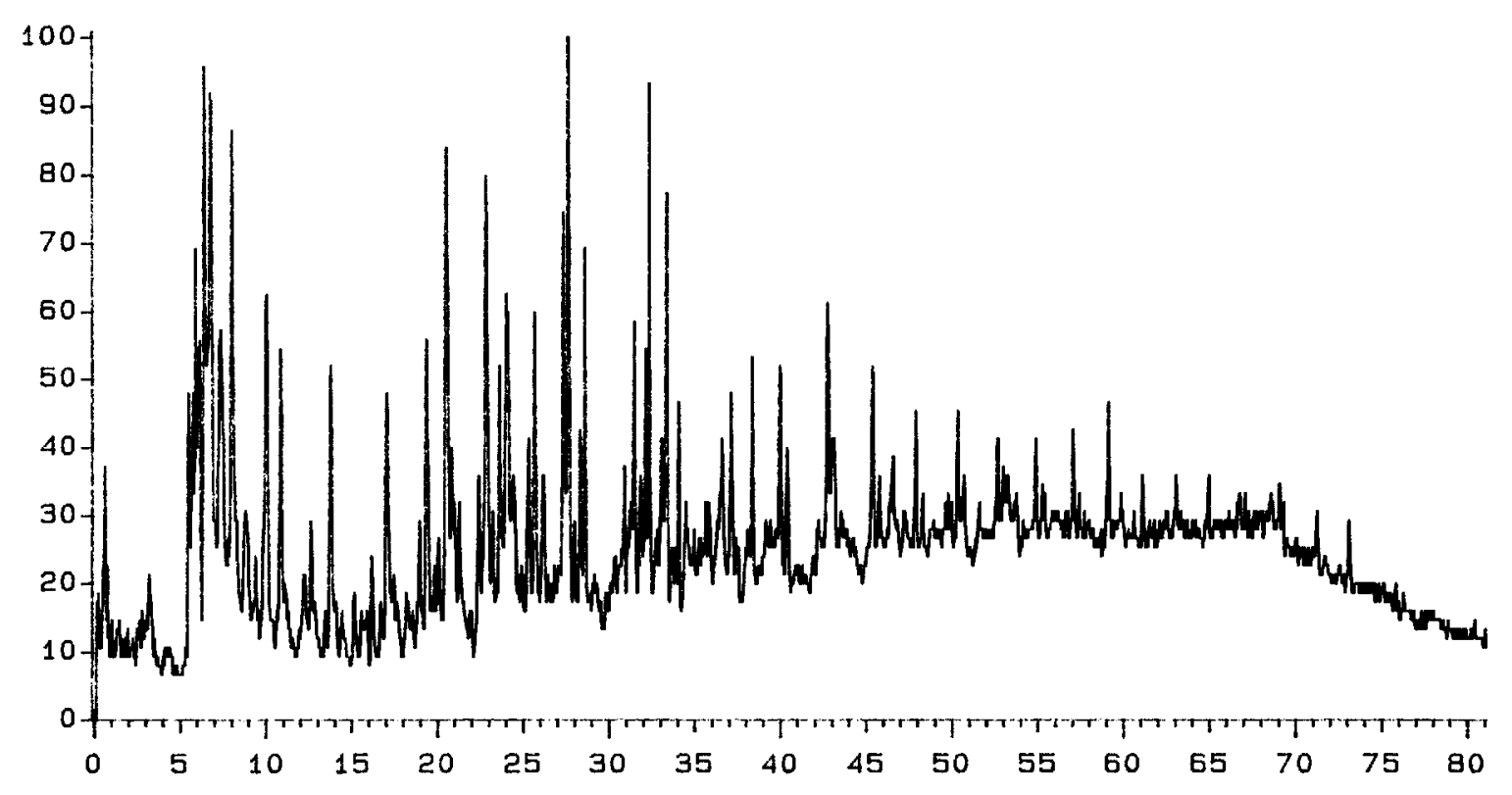

Figure 83. Total ion chromatogram of pyrolyzates from DECS-12, hvAb Pittsburgh seam, PA. 


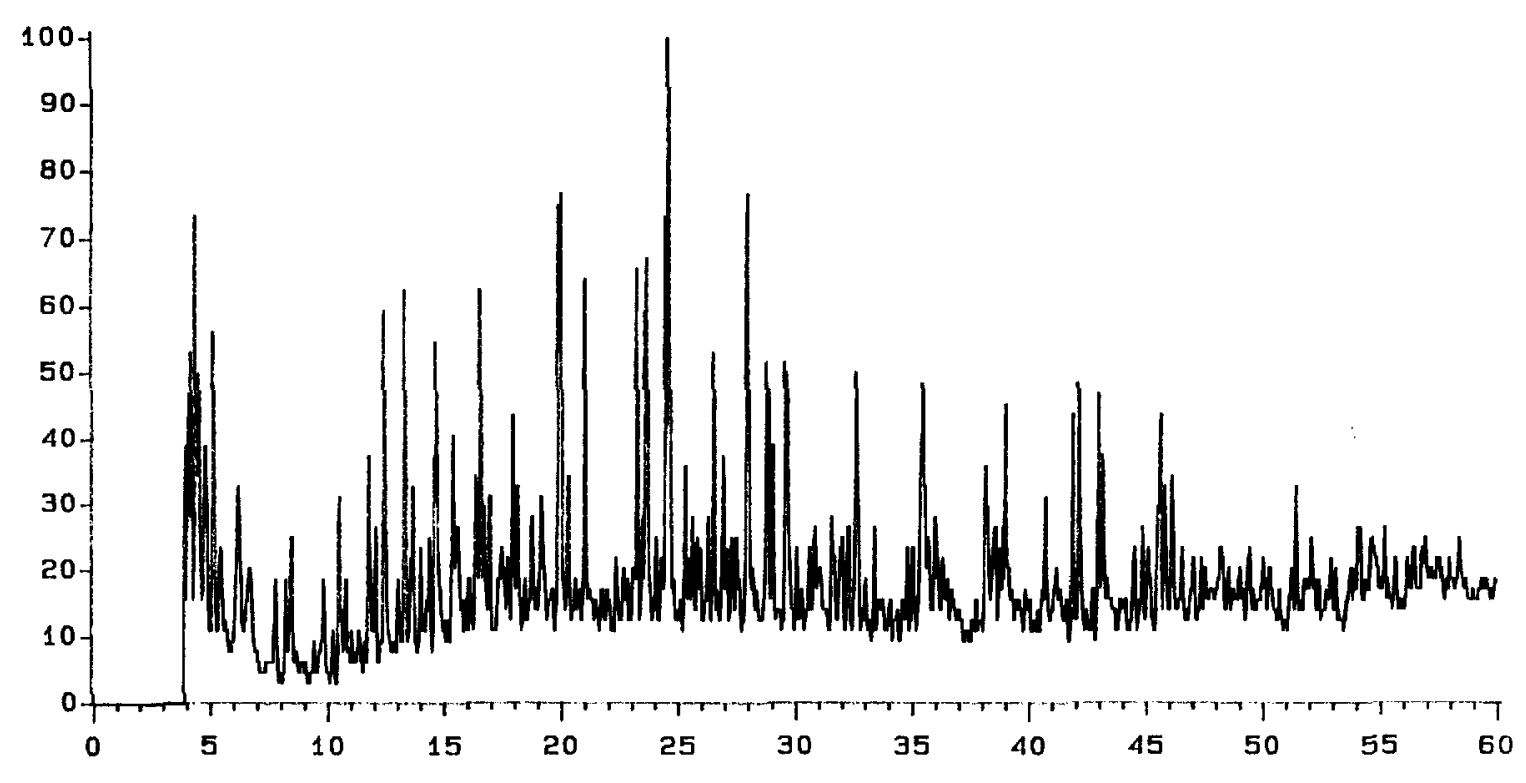

Figure 84. Total ion chromatogram of pyrolyzates from DECS-13, mvb Sewell seam, WV.

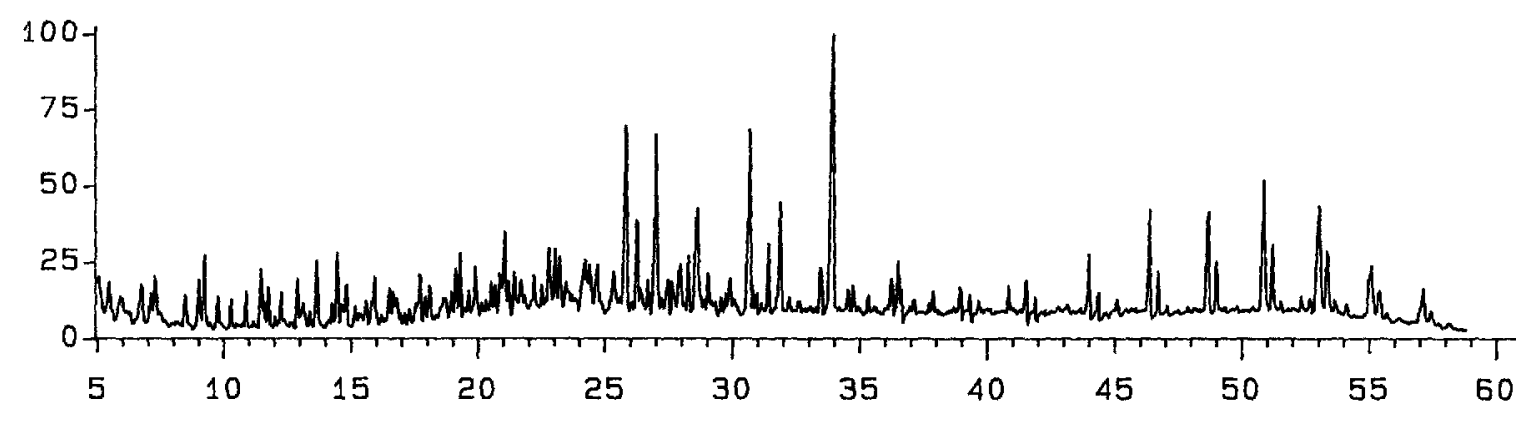

Figure 85. Total ion chromatogram of pyrolyzates from DECS-17, hvAb Blind Canyon seam, UT. 


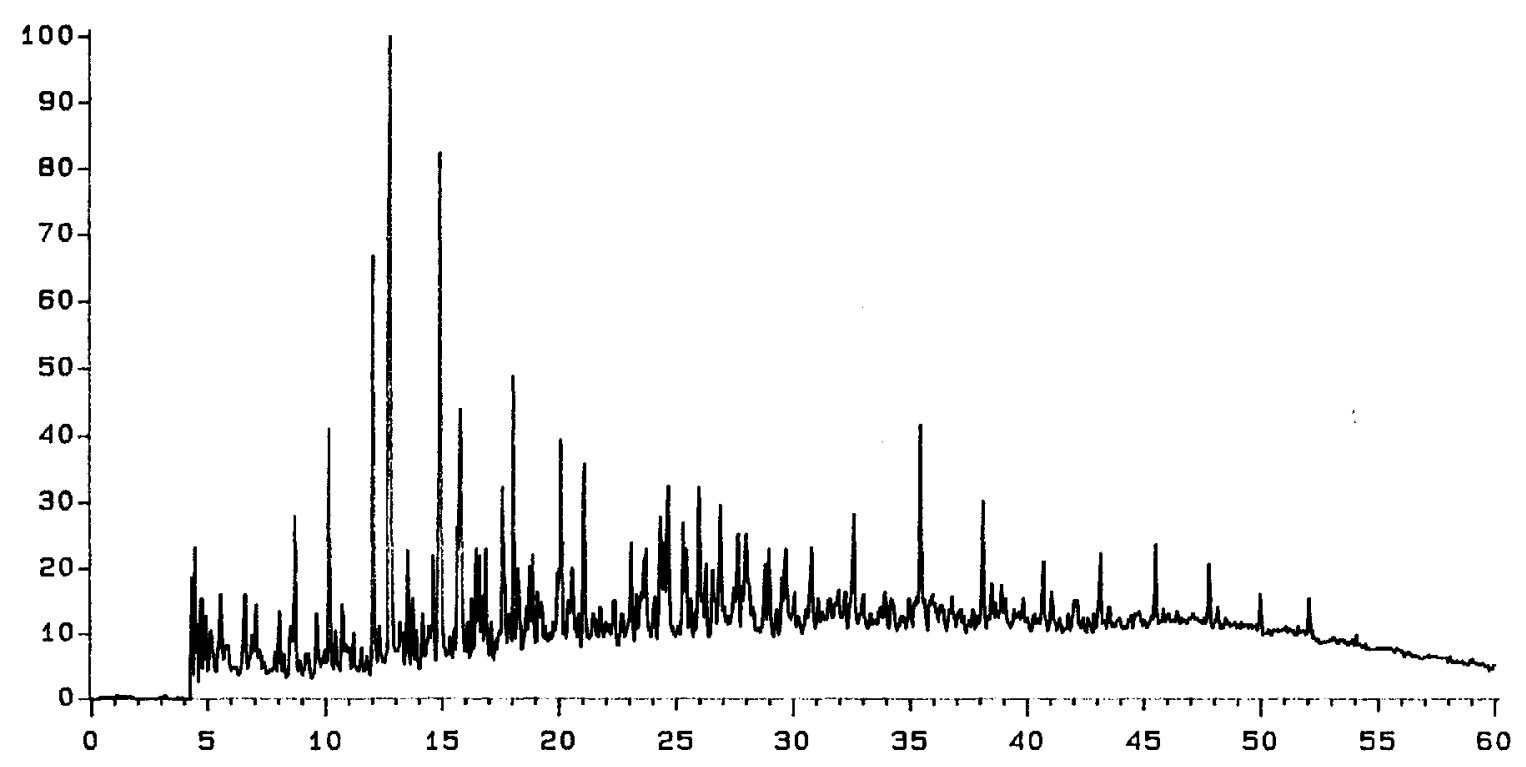

Figure 86. Total ion chromatogram of pyrolyzates from DECS-18, hvBb Kentucky \#9 seam, KY.

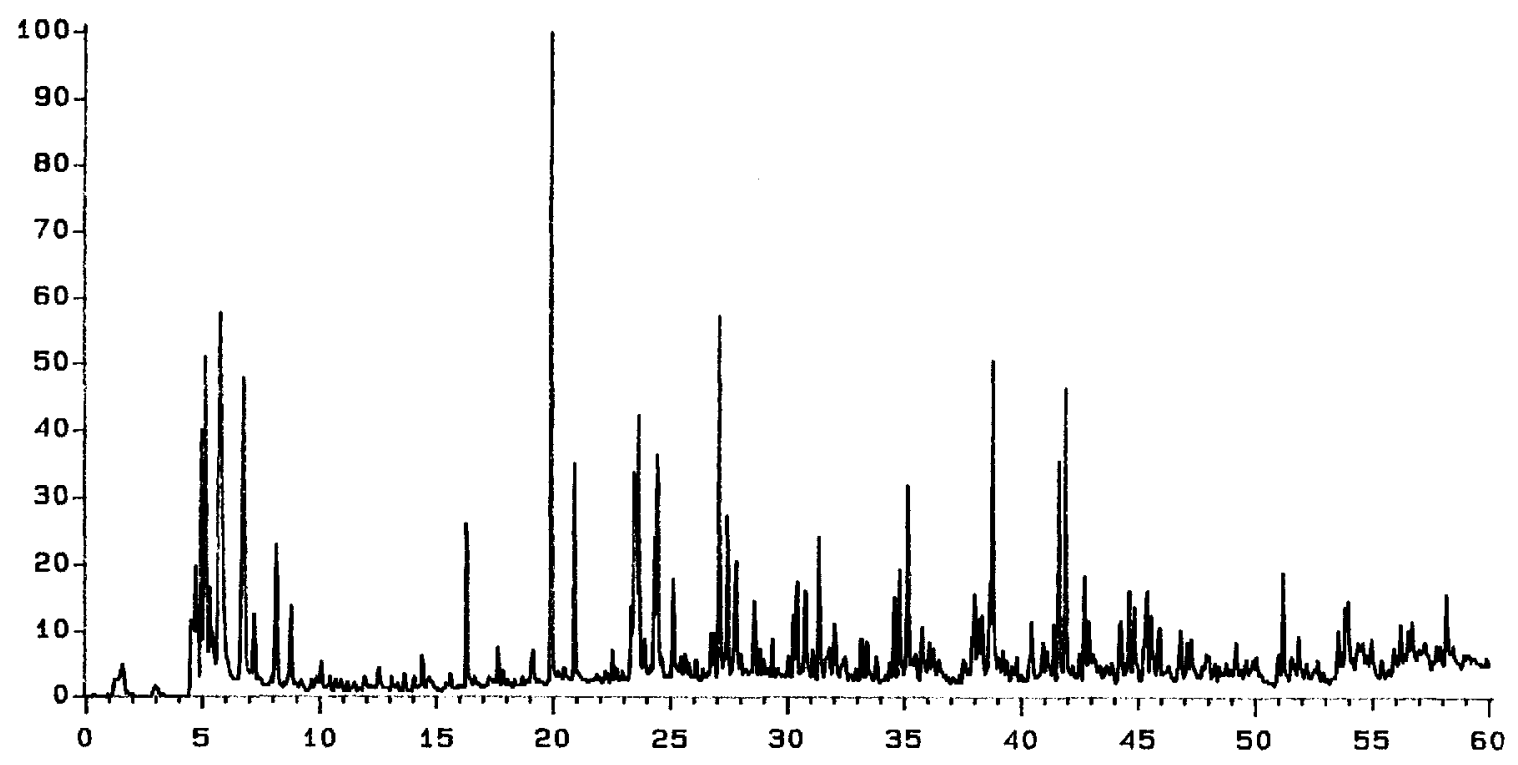

Figure 87. Total ion chromatogram of pyrolyzates from DECS-19, lvb Pocahontas \#3 seam, VA. 


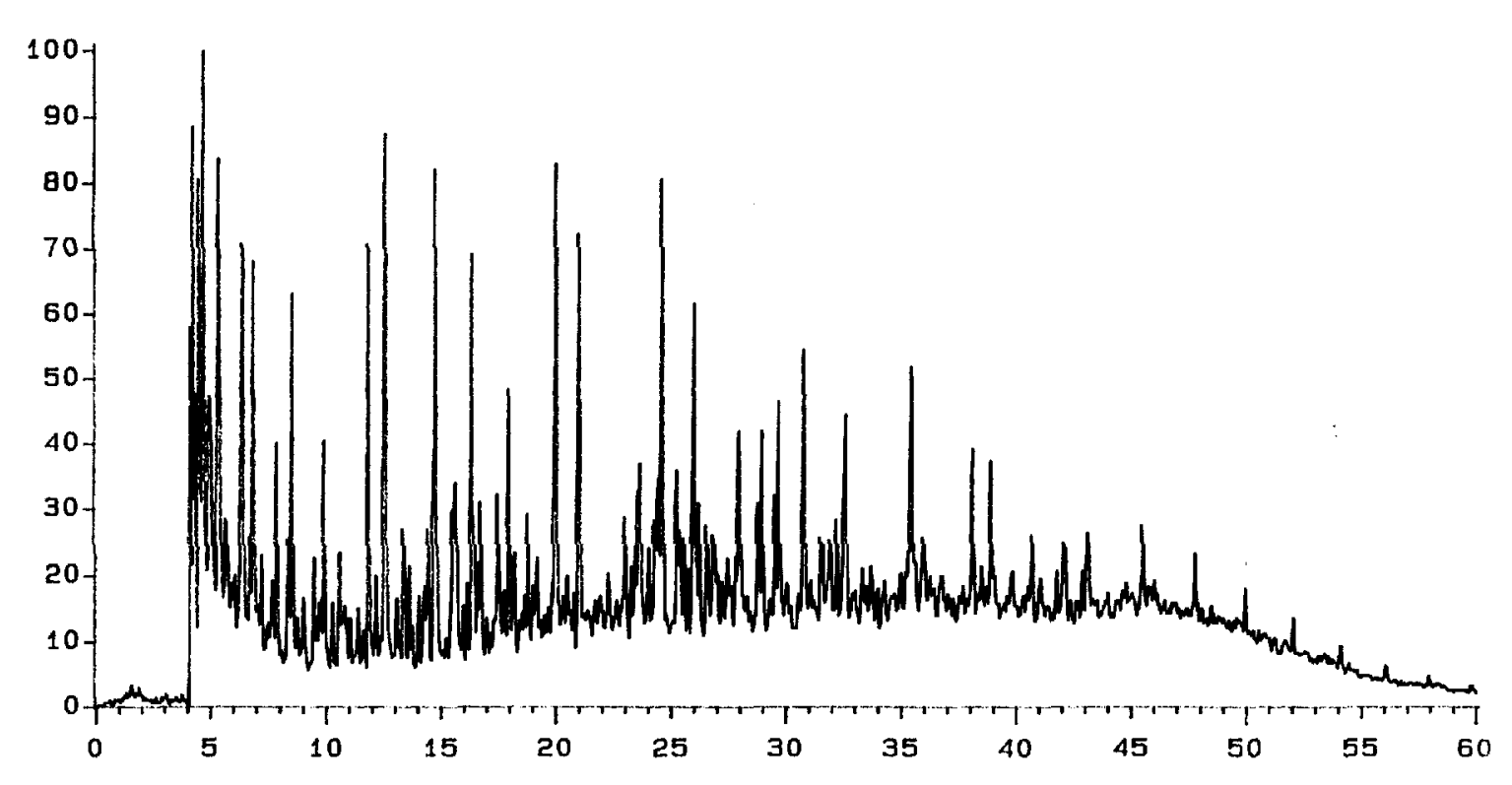

Figure 88. Total ion chromatogram of pyrolyzates from DECS-23, hvAb Pittsburgh seam, PA.

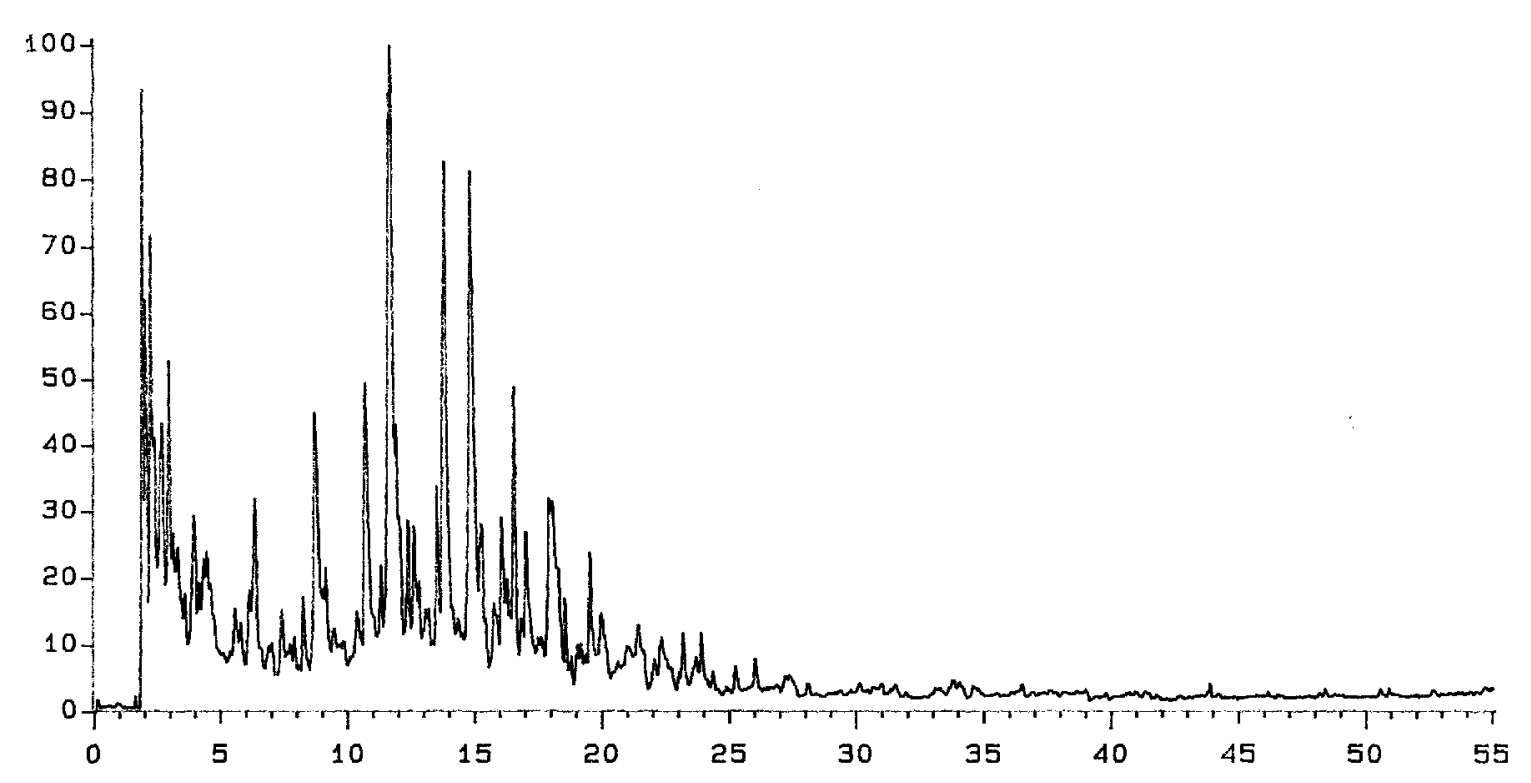

Figure 89. Total ion chromatogram of pyrolyzates from DECS-24, hvCb Illinois \#6 seam, IL. 


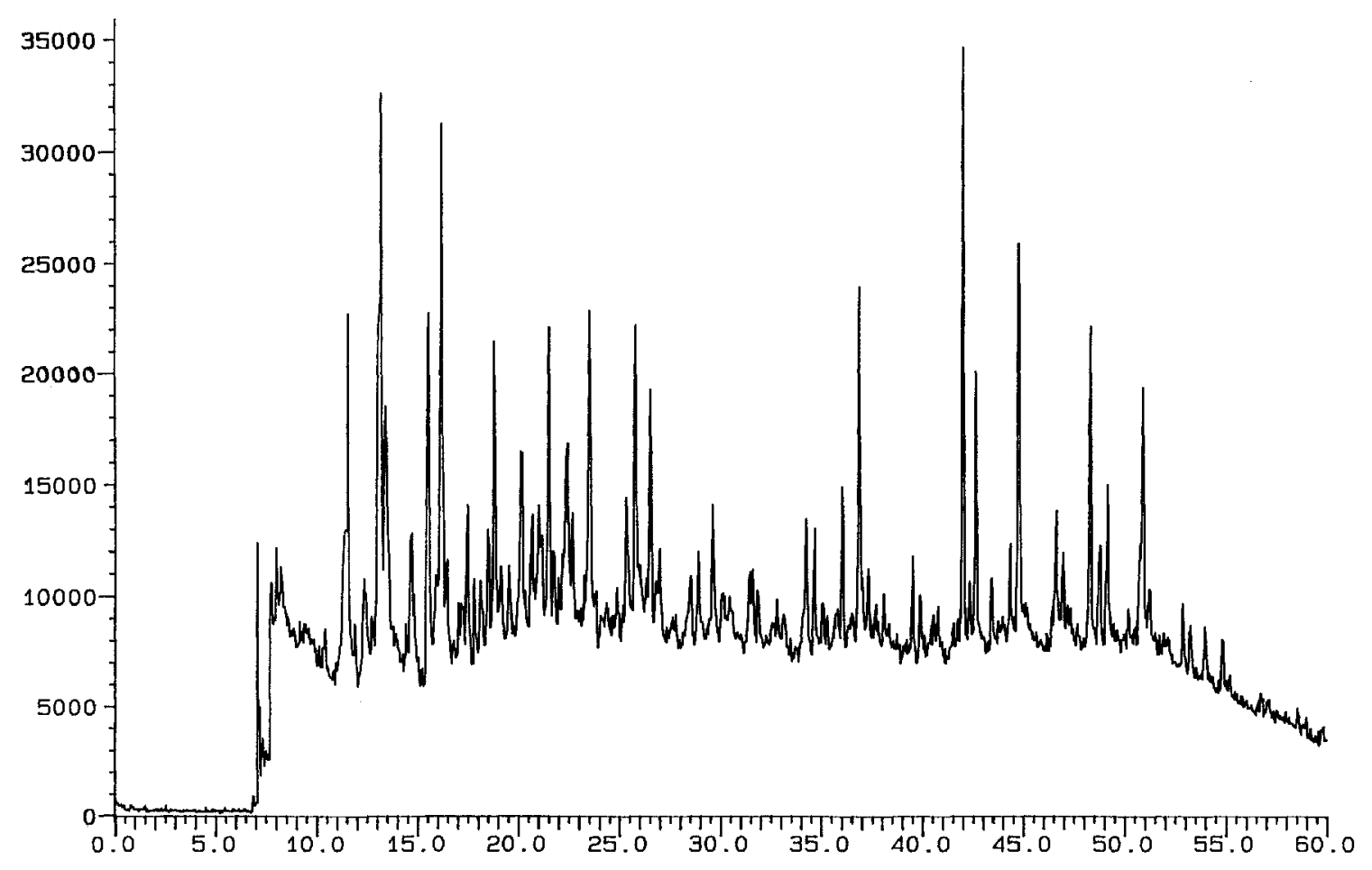

Figure 90. Total ion chromatogram of pyrolyzates from DECS-25, ligA Pust seam, MT.

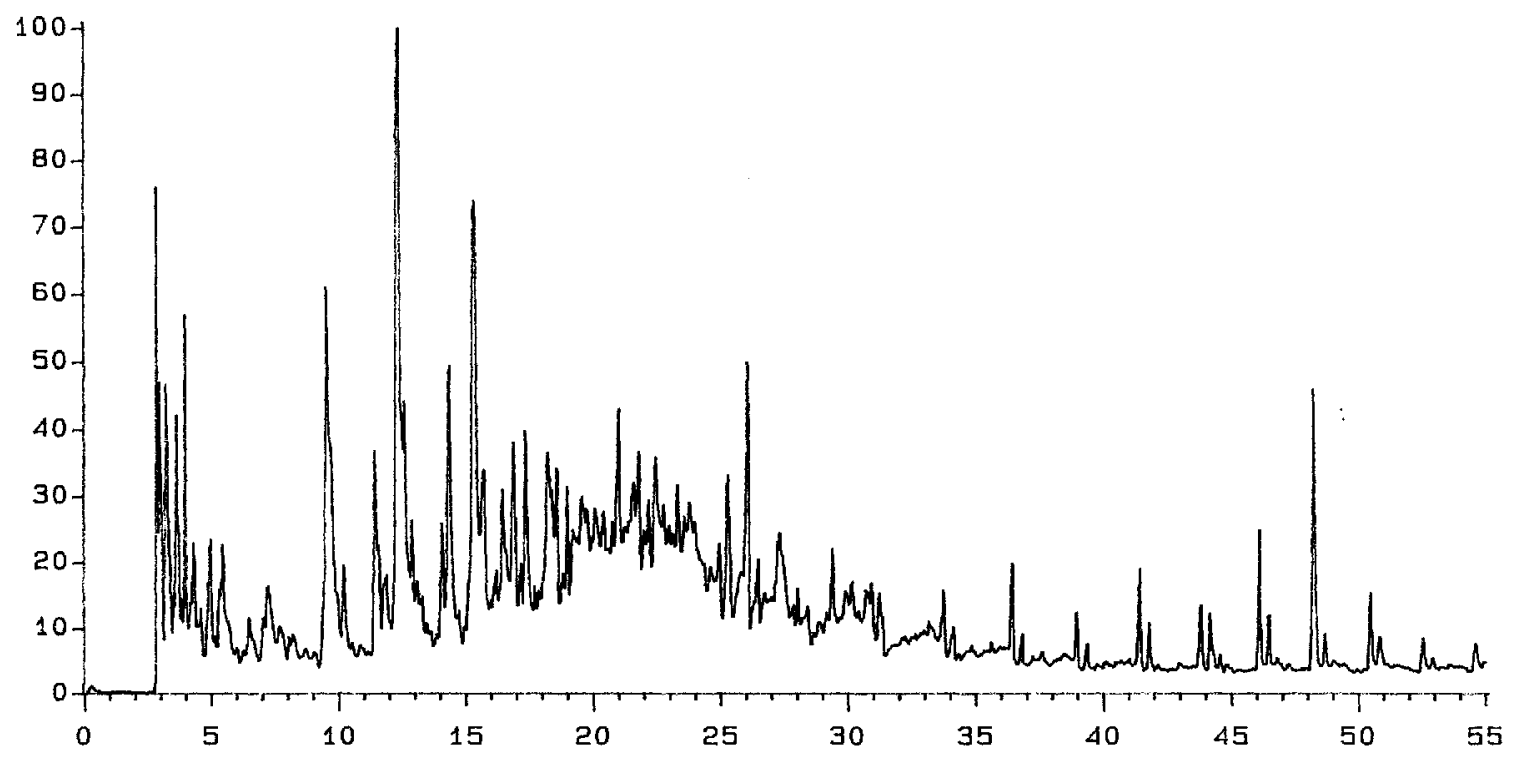

Figure 91. Total ion chromatogram of pyrolyzates from DECS-26, subB Wyodak seam, WY. 


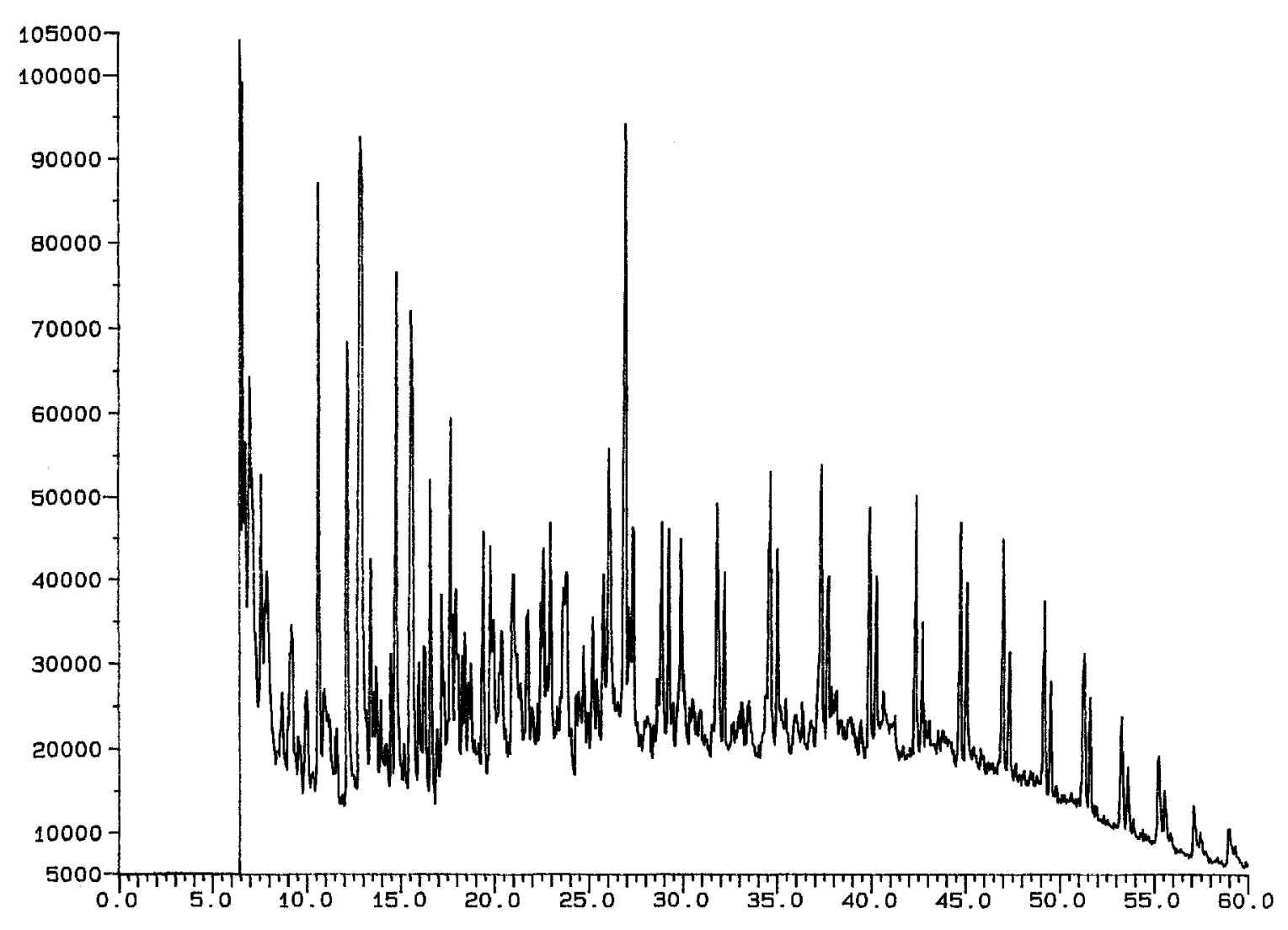

Figure 92. Total ion chromatogram of pyrolyzates from DECS-27, subA Deadman seam, WY.

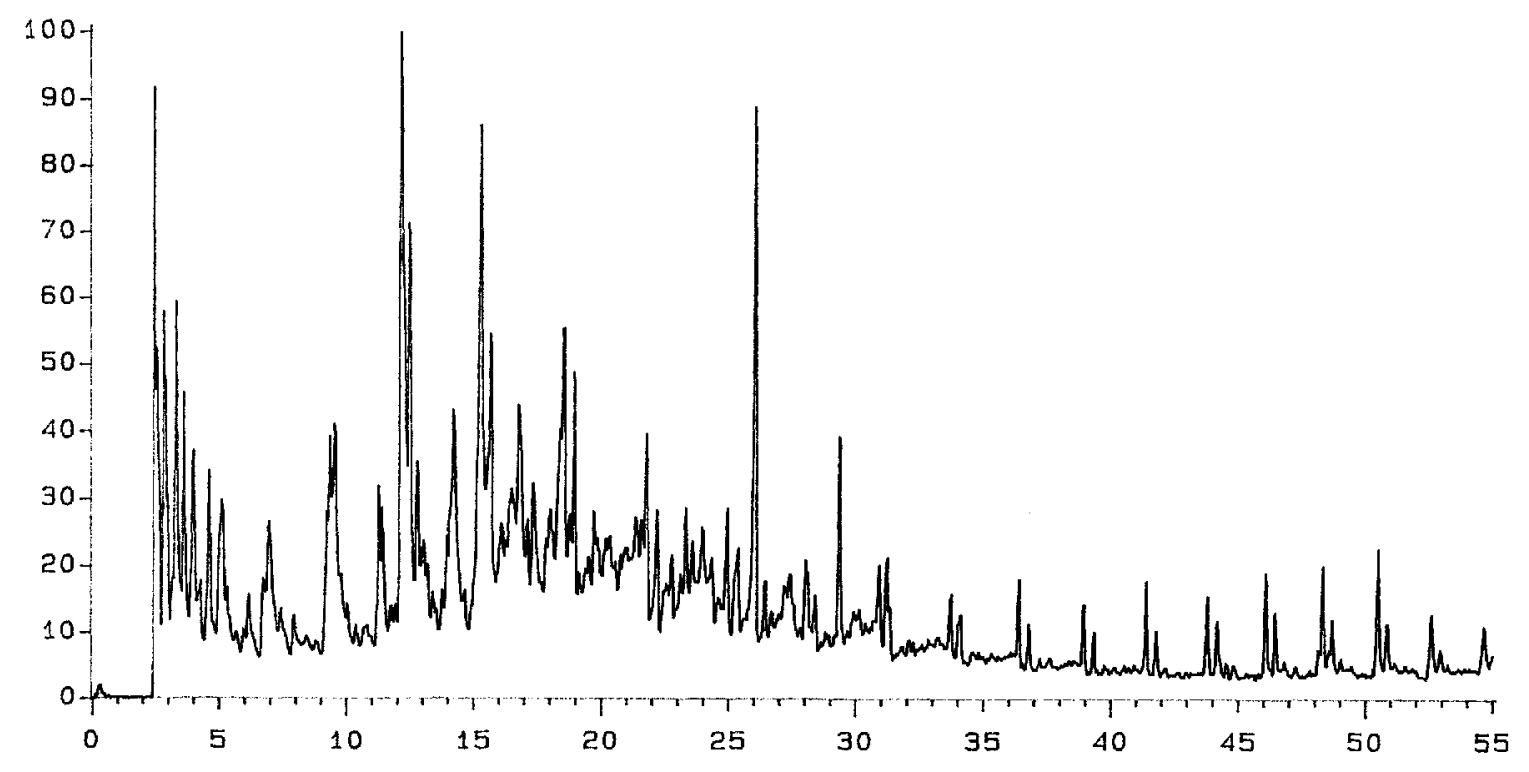

Figure 93. Total ion chromatogram of pyrolyzates from DECS-28, hvCb Green seam, AZ. 


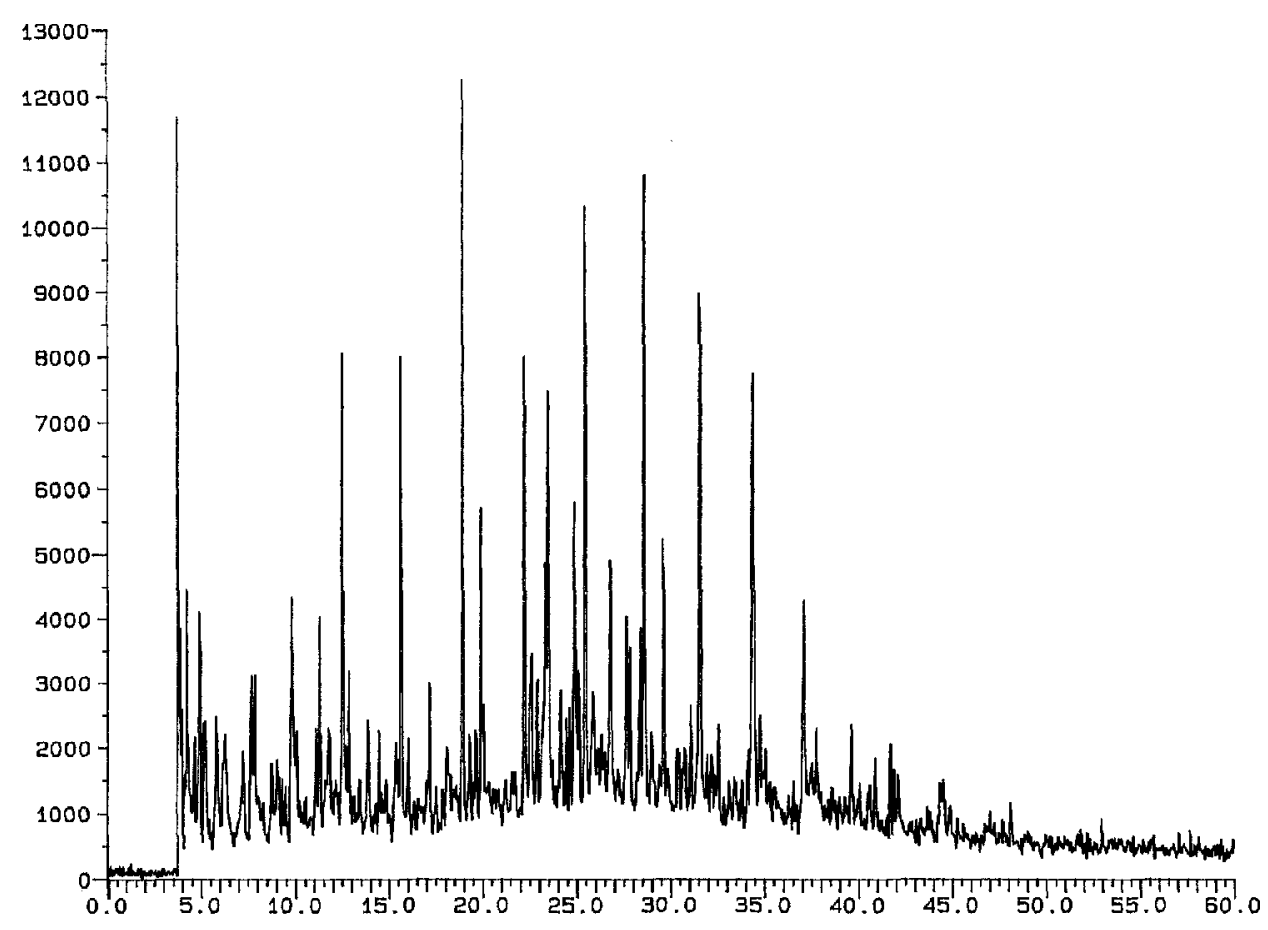

Figure 94. Total ion chromatogram of pyrolyzates from DECS-29, hvAb U. Banner \#3 seam, VA.

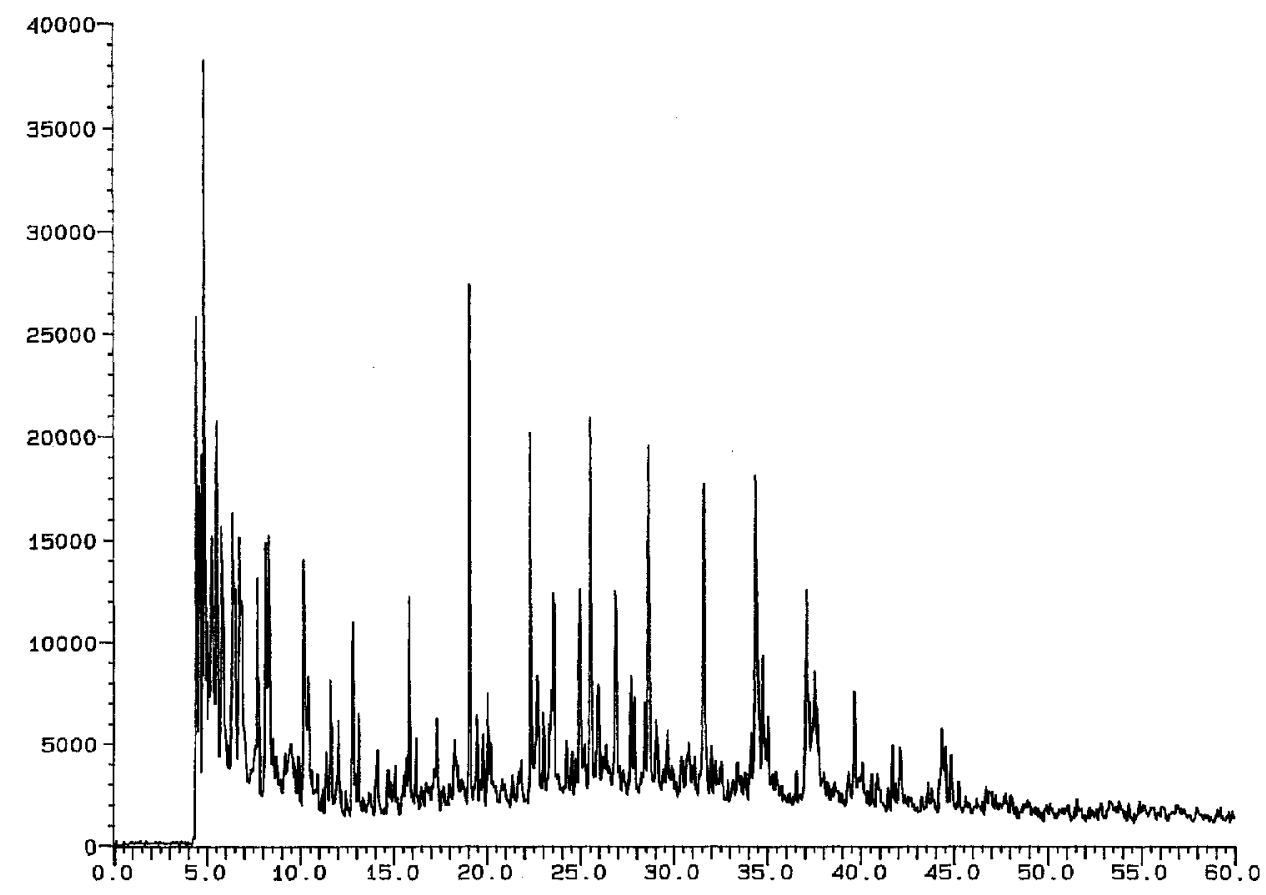

Figure 95. Total ion chromatogram of pyrolyzates from DECS-30, mvb Splash Dam seam, VA. 


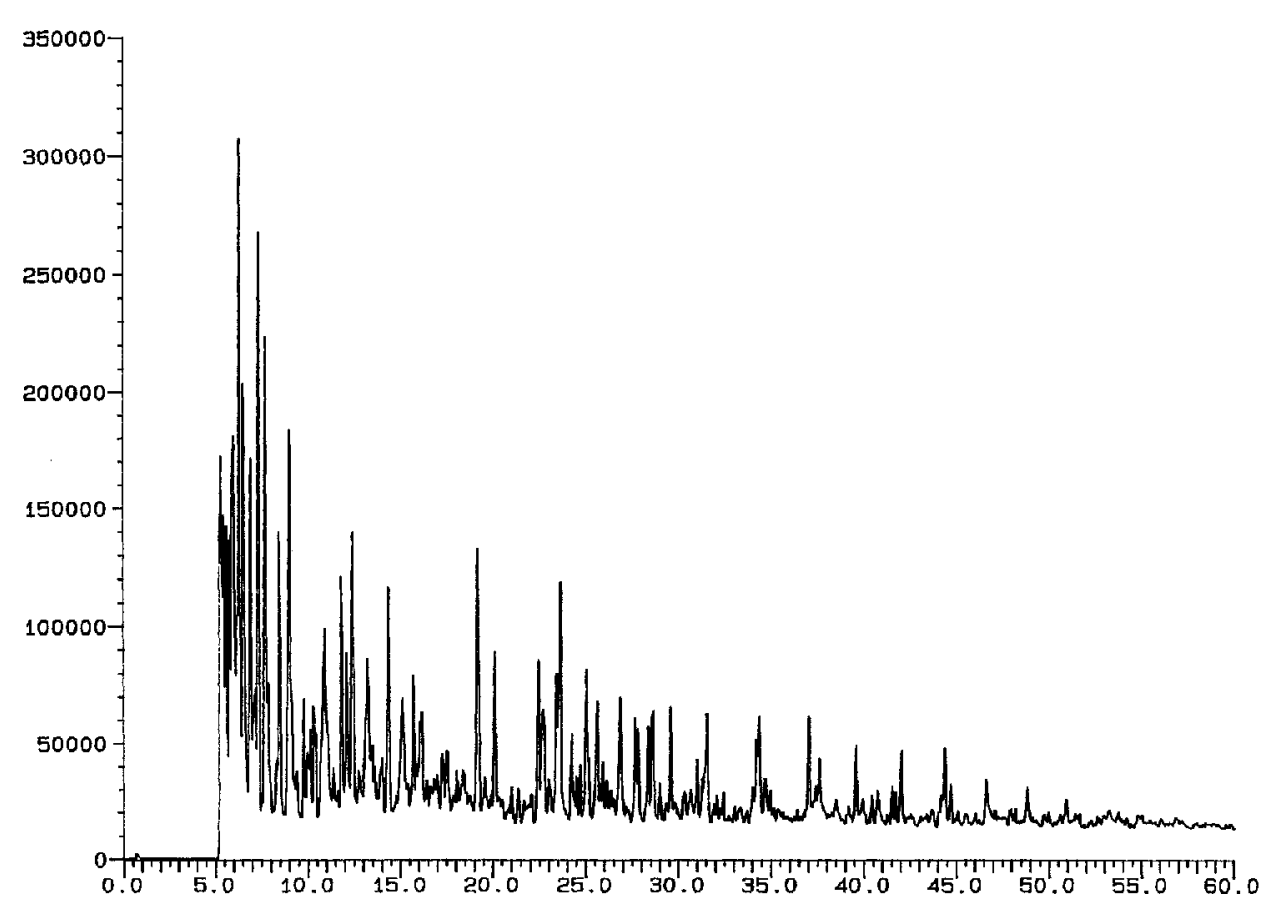

Figure 96. Total ion chromatogram of pyrolyzates from DECS-31, hvAb Pond Creek seam, KY.

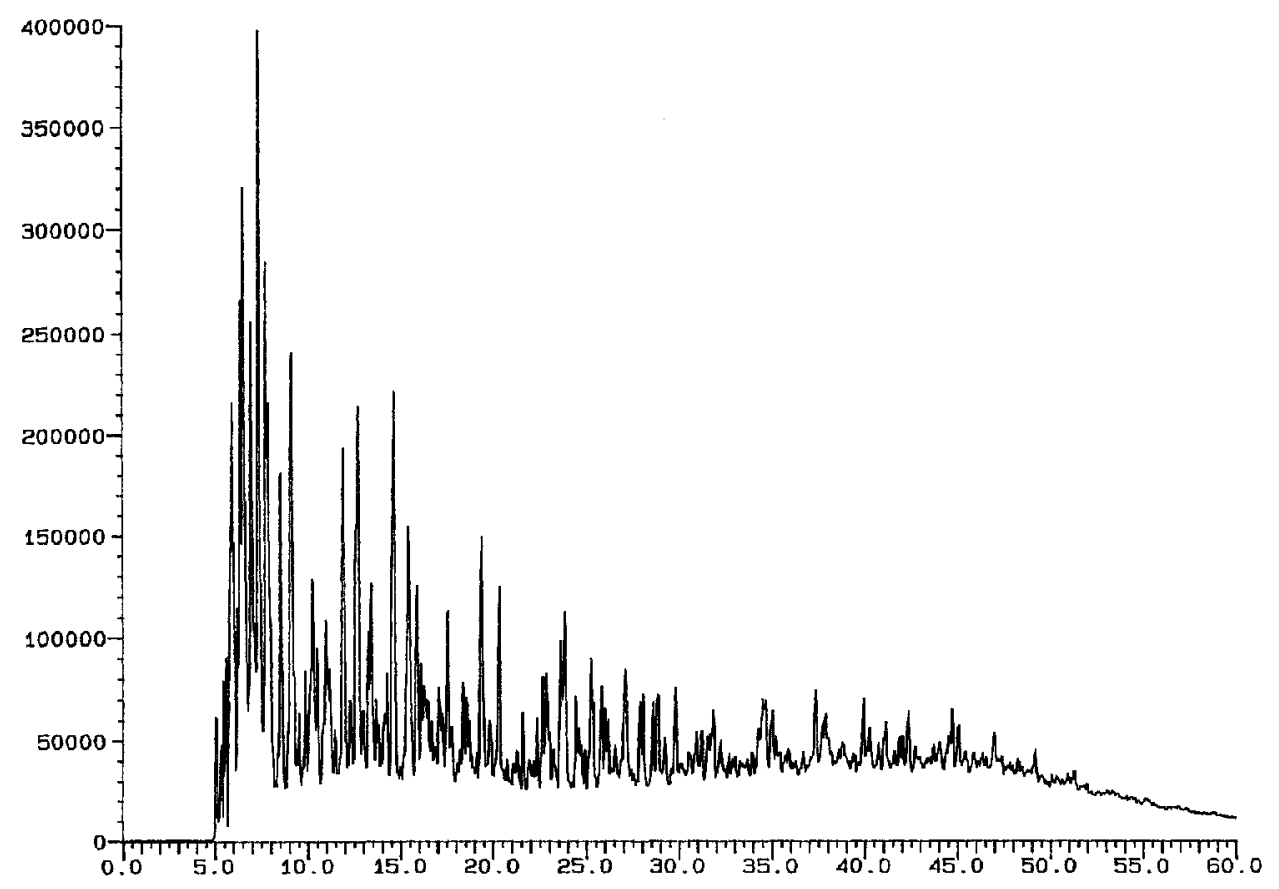

Figure 97. Total ion chromatogram of pyrolyzates from DECS-32, hvAb Stockton-Lewiston seam, WV. 


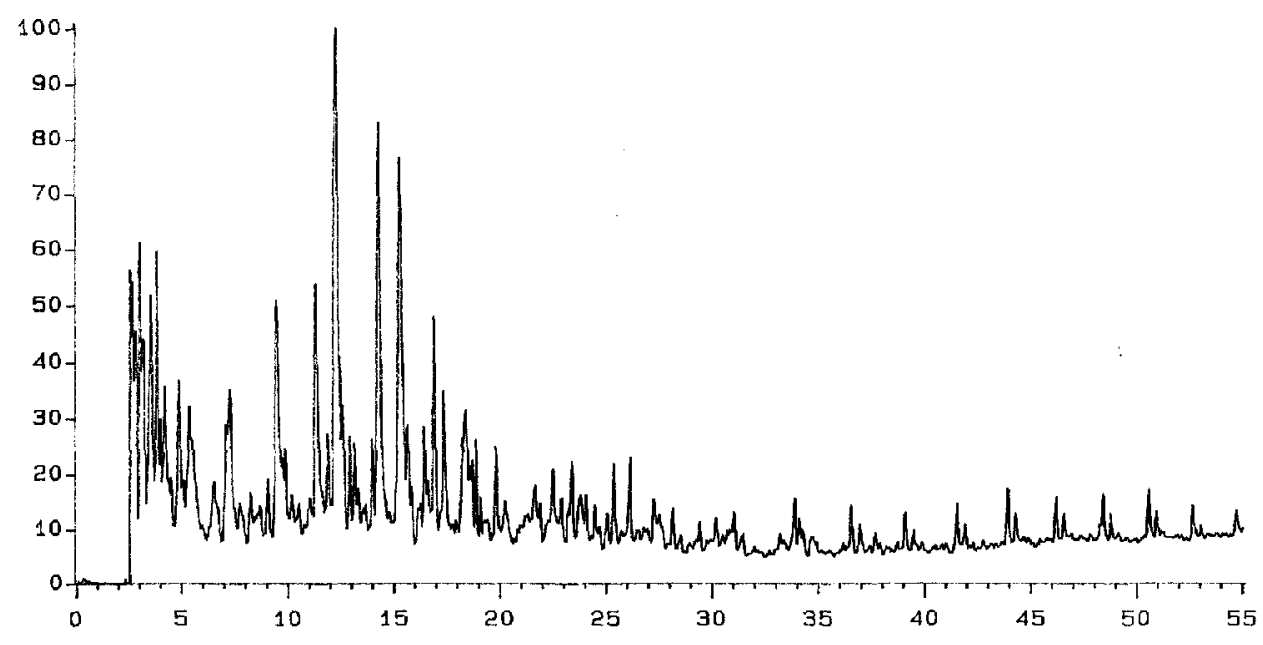

Figure 98. Total ion chromatogram of pyrolyzates from DECS-33, hvBb Ohio \#4A seam, $\mathrm{OH}$. 
Table 9. Structural parameters determined by $\mathrm{py} / \mathrm{gc} / \mathrm{ms}$, flash pyrolysis temperature of $610^{\circ} \mathrm{C}$, heating rate $10^{\circ} \mathrm{C} / \mathrm{ms}$, pyrolysis time $10 \mathrm{~s}$ (percent of total gc-amenable products).

\begin{tabular}{|c|c|c|c|c|c|c|c|}
\hline \multicolumn{4}{|c|}{ sample } & \multirow{2}{*}{$\begin{array}{l}\text { n-alkanes } \\
\text { and } \\
\text { alkenes }\end{array}$} & \multirow[b]{2}{*}{ phenols } & \multirow{2}{*}{$\begin{array}{l}\text { non-oxygenated } \\
\text { aromatic } \\
\text { hydrocarbons } \\
\end{array}$} & \multirow{2}{*}{$\begin{array}{c}\text { unident- } \\
\text { ified } \\
\end{array}$} \\
\hline number & seam & rank & state & & & & \\
\hline DECS-1 & Bottom & subC & $\mathrm{TX}$ & 39.2 & 8.3 & 37.1 & 15.4 \\
\hline DECS-2 & Illinois \#6 & hvCb & IL & 26.7 & 21.5 & 35.6 & 16.2 \\
\hline DECS-8 & Smith-Roland & subC & WY & 27.2 & 15.6 & 14.3 & 42.9 \\
\hline DECS-9 & Dietz & subB & MT & 34.9 & 17.3 & 6.7 & 41.1 \\
\hline DECS-11 & Beulah & $\operatorname{lig} A$ & ND & 37.3 & 32.8 & 12.9 & 17.0 \\
\hline DECS-12 & Pittsburgh & hvAb & PA & $18.1^{*}$ & $31.3^{*}$ & $51.2^{*}$ & \\
\hline DECS-13 & Sewell & $m v b$ & WV & 32.2 & 16.8 & 19.5 & 31.5 \\
\hline DECS-17 & Blind Canyon & hvAb & UT & 24.3 & 5.4 & 5.5 & 64.8 \\
\hline DECS-18 & Kentucky \#9 & hvBb & KY & 41.5 & 22.3 & 7.6 & 28.6 \\
\hline DECS-19 & Pocahontas \#3 & Ivb & VA & 4.4 & 3.0 & 37.1 & 55.5 \\
\hline DECS-23 & Pittsburgh & hvAb & PA & 37.1 & 15.8 & 36.8 & 10.3 \\
\hline DECS-24 & Illinois \#6 & $\mathrm{hvCb}$ & IL & 27.4 & 27.5 & 27.8 & 17.4 \\
\hline DECS-25 & Pust & $\operatorname{lig} A$ & MT & 19.9 & 8.8 & 1.6 & 69.7 \\
\hline DECS-26 & Wyodak & subB & WY & 34.8 & 26.6 & 27.2 & 11.4 \\
\hline DECS-27 & Deadman & subA & WY & 29.4 & 11.6 & 8.5 & 50.5 \\
\hline DECS-28 & Green & $\mathrm{hvCb}$ & $A Z$ & 36.5 & 25.6 & 27.2 & 10.6 \\
\hline DECS-29 & Upper Banner \#3 & hvAb & VA & 21.8 & 3.5 & 10.7 & 64.0 \\
\hline DECS-30 & Splash Dam & $m v b$ & VA & 28.0 & 3.6 & 4.3 & 64.1 \\
\hline DECS-31 & Pond Creek & hvAb & KY & 17.9 & 15.4 & 4.5 & 62.2 \\
\hline DECS-32 & Stockton-Lewiston & hvAb & WV & 15.3 & 20.1 & 10.3 & 53.5 \\
\hline DECS-33 & Ohio \#4A & hvBb & $\mathrm{OH}$ & 32.2 & 19.1 & 34.7 & 14.0 \\
\hline
\end{tabular}

* as percent of identified products 
Table 10. Structural parameters determined by py/gc/ms, flash pyrolysis temperature of $610^{\circ} \mathrm{C}$, heating rate $10^{\circ} \mathrm{C} / \mathrm{ms}$, pyrolysis time $10 \mathrm{~s}$ (percent of identified products).

\begin{tabular}{|c|c|c|c|c|c|c|}
\hline \multicolumn{4}{|c|}{ sample } & \multirow{2}{*}{$\begin{array}{c}\text { n-alkanes } \\
\text { and } \\
\text { alkenes } \\
\end{array}$} & \multirow[b]{2}{*}{ phenols } & \multirow{2}{*}{$\begin{array}{c}\text { non-oxygenated } \\
\text { aromatic } \\
\text { hydrocarbons } \\
\end{array}$} \\
\hline number & seam & rank & state & & & \\
\hline DECS-1 & Bottom & subC & $\mathrm{TX}$ & 46.3 & 9.8 & 43.9 \\
\hline DECS-2 & Illinois \#6 & hvCb & IL & 31.9 & 25.6 & 42.5 \\
\hline DECS-8 & Smith-Roland & subC & WY & 47.6 & 27.4 & 25.0 \\
\hline DECS-9 & Dietz & subB & MT & 59.3 & 29.4 & 11.3 \\
\hline DECS-11 & Beulah & $\operatorname{lig} A$ & ND & 44.9 & 39.6 & 15.5 \\
\hline DECS-12 & Pittsburgh & hvAb & PA & 18.1 & 31.3 & 51.2 \\
\hline DECS-13 & Sewell & $\mathrm{mvb}$ & WV & 47.0 & 24.5 & 28.5 \\
\hline DECS-17 & Blind Canyon & hvAb & UT & 69.1 & 15.3 & 15.6 \\
\hline DECS-18 & Kentucky \#9 & hvBb & KY & 58.2 & 31.2 & 10.6 \\
\hline DECS-19 & Pocahontas \#3 & Ivb & VA & 9.88 & 6.74 & 83.3 \\
\hline DECS-23 & Pittsburgh & hvAb & PA & 43.6 & 17.6 & 41.0 \\
\hline DECS-24 & Illinois \#6 & $\mathrm{hvCb}$ & IL & 33.1 & 33.3 & 33.6 \\
\hline DECS-25 & Pust & $\operatorname{lig} A$ & MT & 65.7 & 29.0 & 5.3 \\
\hline DECS-26 & Wyodak & subB & WY & 39.3 & 30.0 & 30.7 \\
\hline DECS-27 & Deadman & subA & WY & 59.4 & 23.4 & 17.2 \\
\hline DECS-28 & Green & $\mathrm{hvCb}$ & $A Z$ & 40.9 & 28.7 & 30.4 \\
\hline DECS-29 & Upper Banner \#3 & hvAb & VA & 60.6 & 9.7 & 29.7 \\
\hline DECS-30 & Splash Dam & $m v b$ & VA & 78.0 & 10.0 & 12.0 \\
\hline DECS-31 & Pond Creek & hvAb & KY & 47.4 & 11.9 & 40.7 \\
\hline DECS-32 & Stockton-Lewiston & hvAb & WV & 32.9 & 22.2 & 44.9 \\
\hline DECS-33 & Ohio \#4A & hvBb & $\mathrm{OH}$ & 37.5 & 22.2 & 40.3 \\
\hline
\end{tabular}




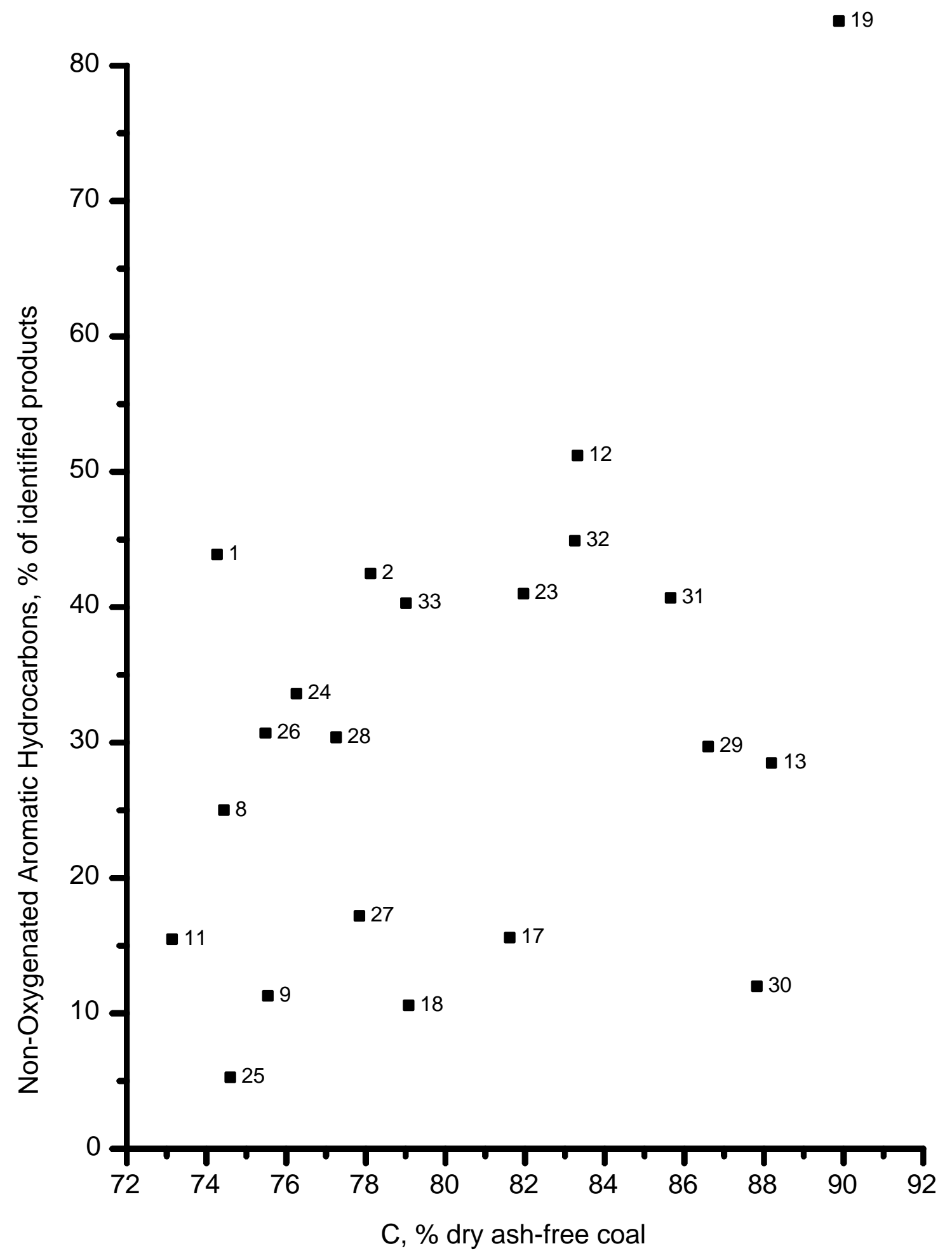

Figure 99. Non-oxygenated aromatic hydrocarbon fraction of identified products vs. carbon content for 21 DECS coals. 


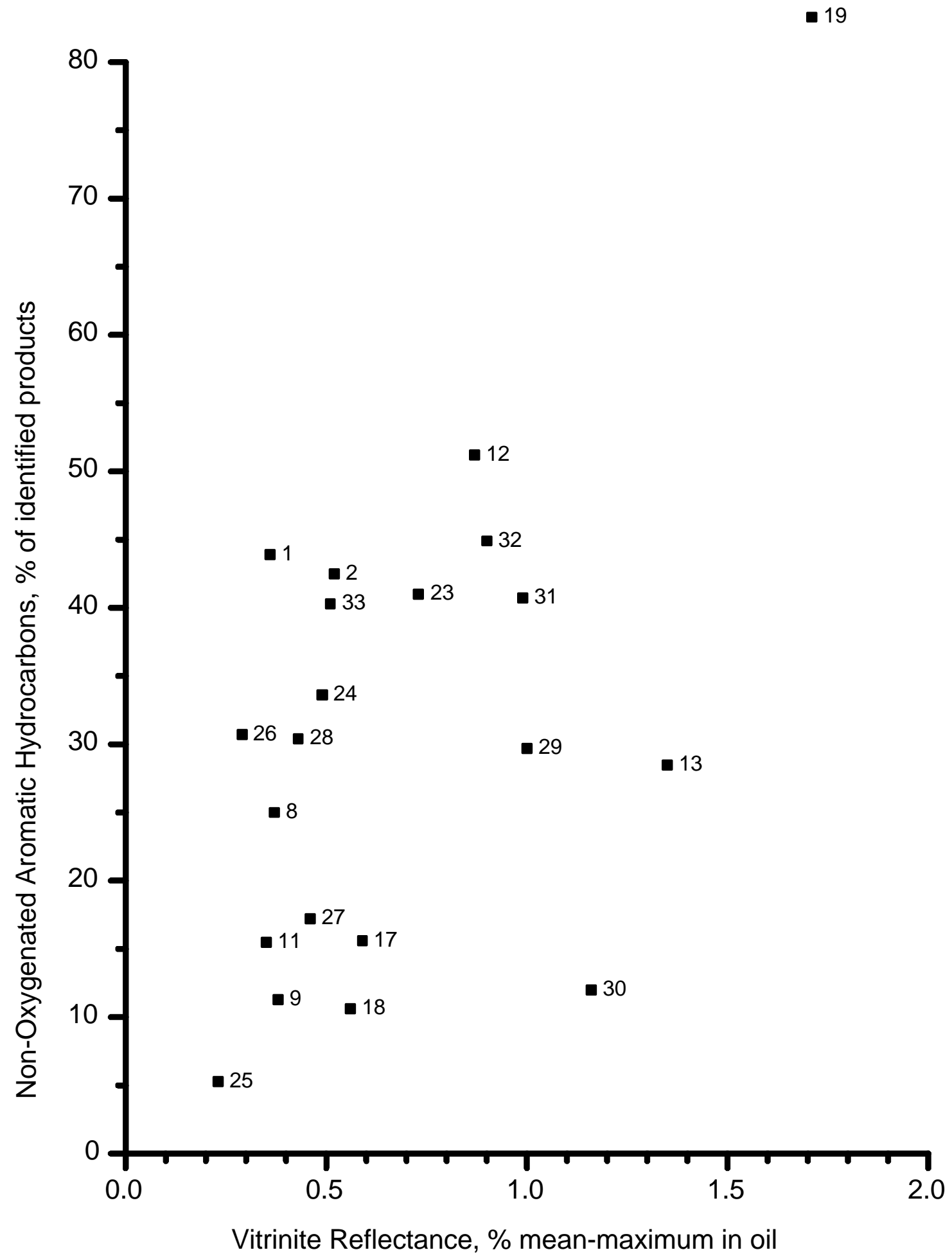

Figure 100. Non-oxygenated aromatic hydrocarbon fraction of identified products vs. vitrinite reflectance for 21 DECS coals. 


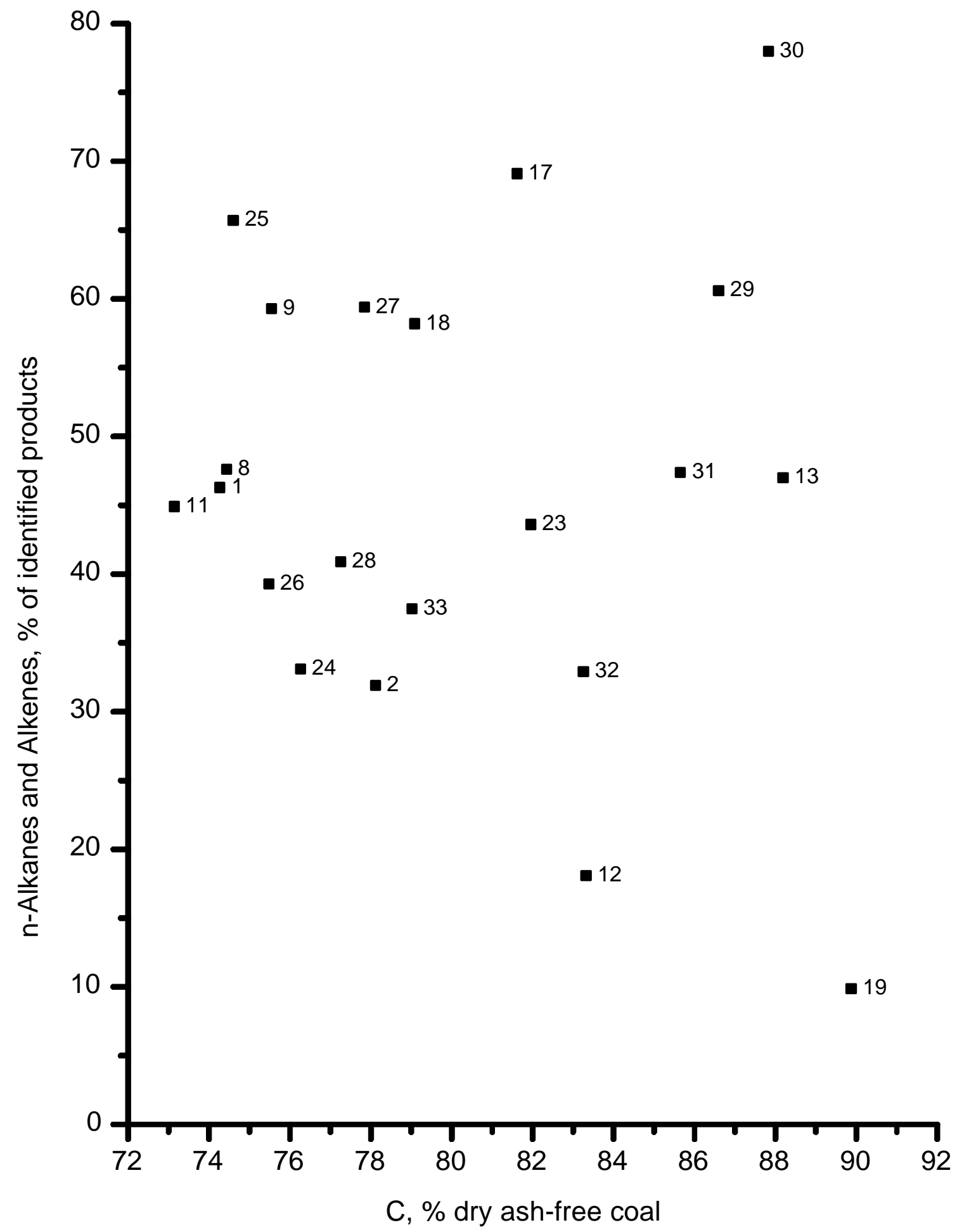

Figure 101. n-Alkanes + alkenes fraction of identified products vs. carbon content for 21 DECS coals. 


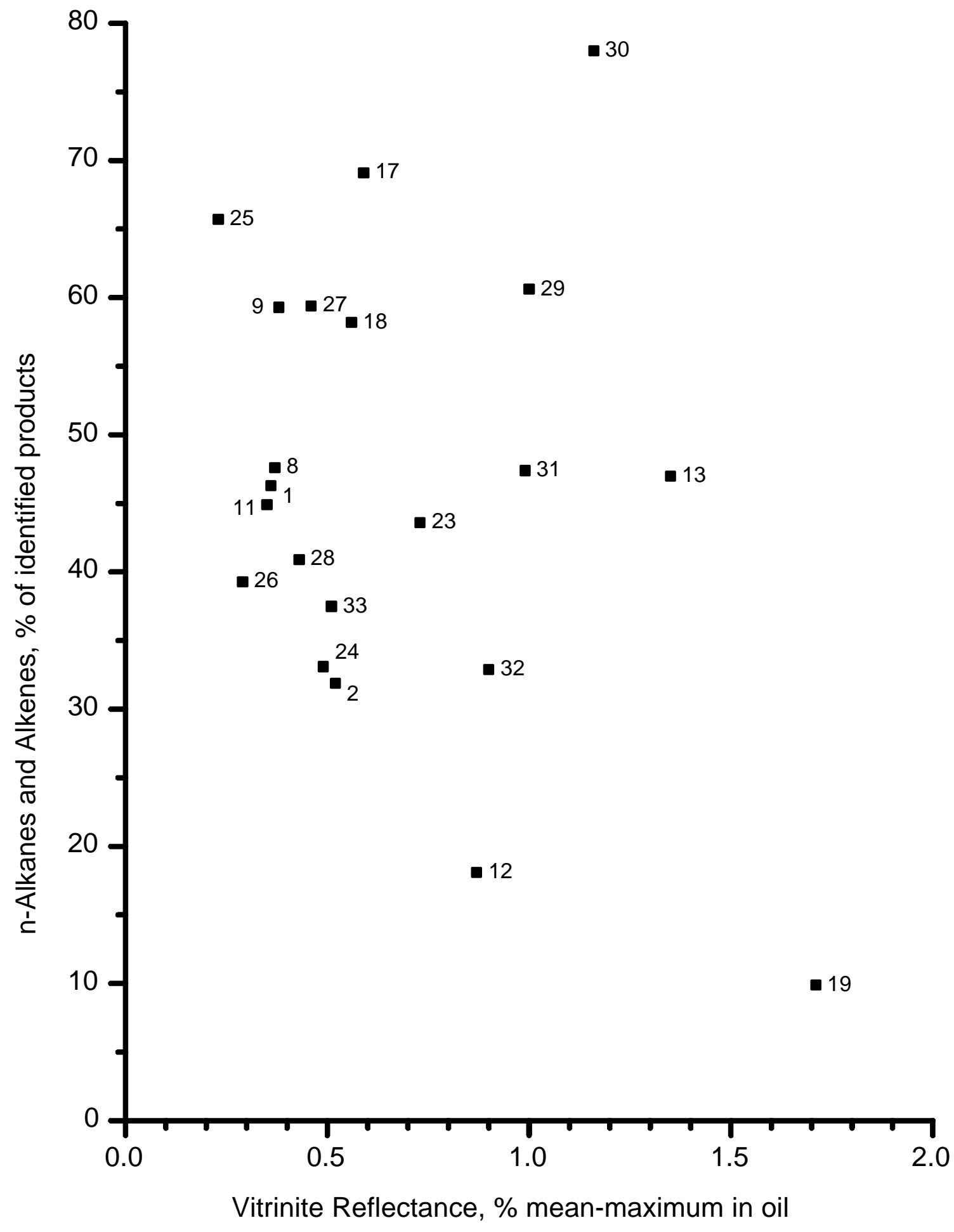

Figure 102. n-Alkanes + alkenes fraction of identified products vs. vitrinite reflectance for 21 DECS coals. 


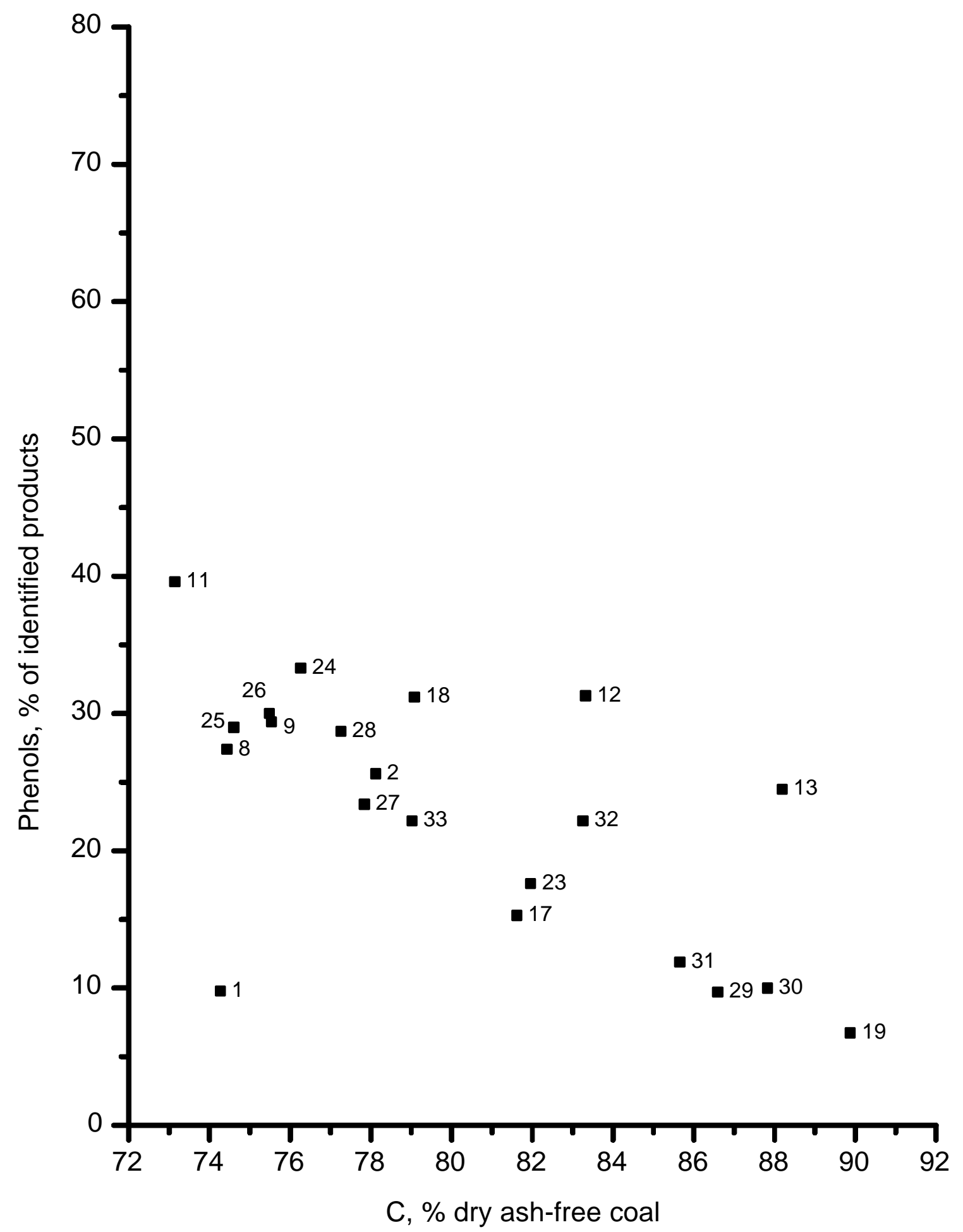

Figure 103. Phenolic fraction of identified products vs. carbon content for 21 DECS coals. 


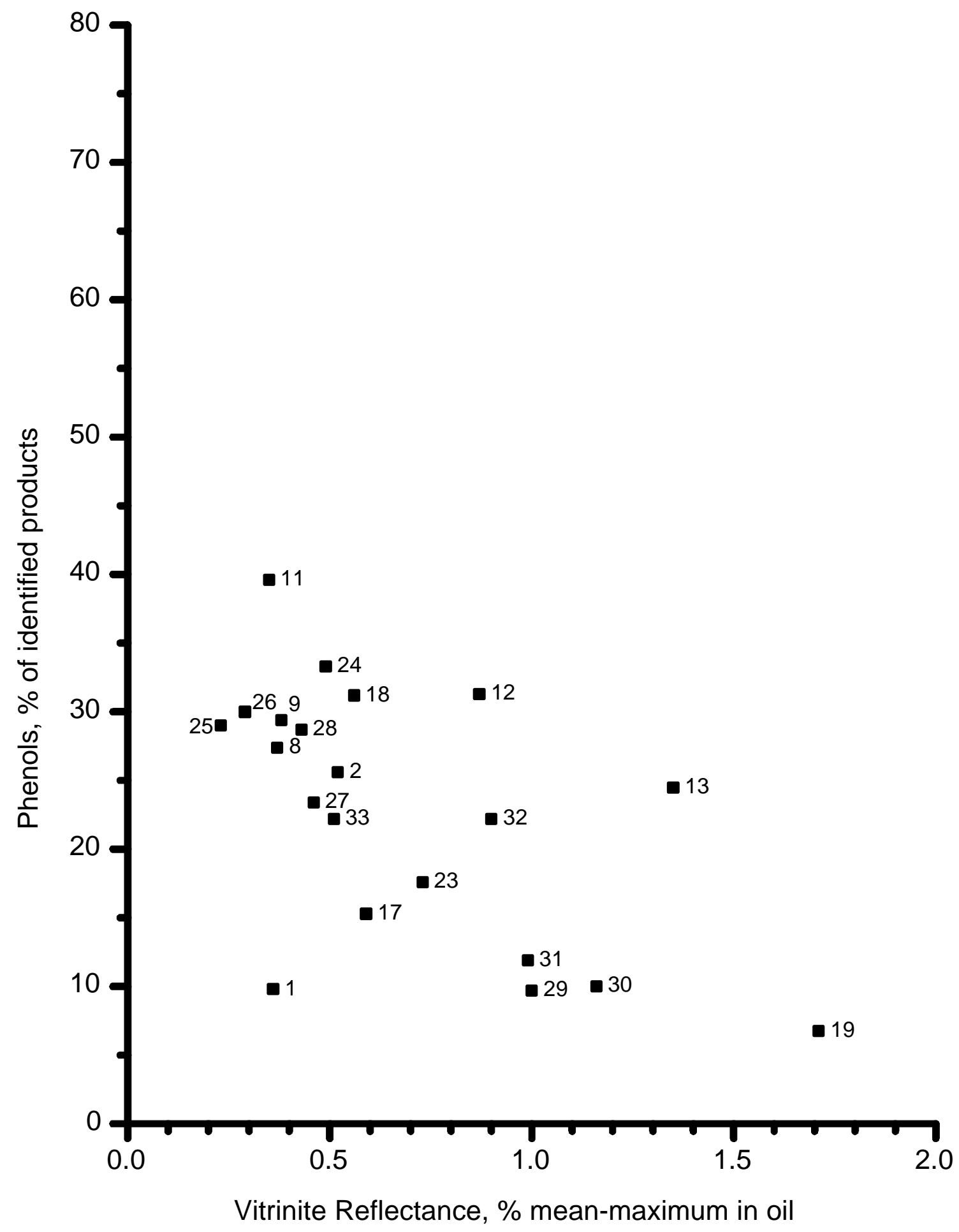

Figure 104. Phenolic fraction of identified products vs. vitrinite reflectance for 21 DECS coals. 


\section{Task 1I. Distribution of Coal Samples to Users}

Distribution of samples took place under the conditions of the contract. Up to $1 \mathrm{~kg}$ ( 2.2 lbs) each of up to 15 samples per year per requestor were distributed to DOE contractors and grantees at no charge to the recipient. Samples were distributed for a wide variety of proposed uses, as summarized for approximately 4 years of the contract in Table 11. Appendix $\mathrm{C}$ lists the agencies receiving samples and/or data during the five-year contract and the following six-month extension period. Numbers in parentheses enumerate separate requests from the same agency. In total, 502 requests were received; most were for more than one sample or data printout.

Table 11. Sample distribution by category of recipient's use, 9/29/93 to 8/15/97.

\begin{tabular}{|lrrrr|}
\hline Category & $\begin{array}{c}\text { number of } \\
\text { samples }\end{array}$ & $\begin{array}{c}\text { percentage of } \\
\text { samples }\end{array}$ & $\begin{array}{c}\text { number of } \\
\text { containers }\end{array}$ & $\begin{array}{c}\text { percentage of } \\
\text { containers }\end{array}$ \\
\hline Liquefaction & 147 & 26 & 360 & 39 \\
Combustion & 88 & 16 & 194 & 21 \\
Physical cleaning & 21 & 4 & 43 & 5 \\
Biological cleaning & 23 & 4 & 33 & 4 \\
Characterization & 80 & 14 & 86 & 9 \\
Education and outreach & 7 & 1 & 7 & 1 \\
Pyrolysis and gasification & 14 & 3 & 14 & 2 \\
Geology & 100 & 18 & 100 & 11 \\
Health and medical & 60 & 11 & 60 & 6 \\
Carbon products & 16 & 3 & 29 & 2 \\
\hline TOTAL & 556 & $100 \%$ & 917 & $100 \%$ \\
\hline
\end{tabular}

A record of distribution of samples and data is shown in Table 12. For record-keeping under the contract, and this Table, a "sample" is any amount of one coal sample provided to one requestor at one time. Thus one $5 \mathrm{~kg}$ foil laminate bag of DECS- 12 sent out is one "sample," but one $300 \mathrm{~g}$ bag each of DECS-1 and -2 sent every year for four years is 8 "samples." Special sample DECS-17 is excluded in accord with the method used under the previous contract, but is added in a consistent manner in the final line of the table. At least 502 DECS and PSOC samples in 1586 containers were distributed during the contract. Numbers of samples distributed from various coal sample banks have been discussed by Vorres et al. (1994) 
Table 12. Samples and data distributed $9 / 29 / 93$ to 3/30/99 (5.5 years)

\begin{tabular}{|c|c|c|c|c|c|c|c|c|c|c|c|c|}
\hline & $\begin{array}{r}\mathrm{D} \\
\text { (exclu }\end{array}$ & $\begin{array}{l}\text { OE samples } \\
\text { ding DECS- }\end{array}$ & & Oth & er PSOC san & ples & & & & & $\begin{array}{l}\text { cial data } \\
\text { quests }\end{array}$ & \\
\hline $\begin{array}{l}\text { Quarter } \\
\text { ending }\end{array}$ & Total & \begin{tabular}{|c|} 
to \\
DOE \\
contractor
\end{tabular} & $\begin{array}{l}\text { to } \\
\text { others }\end{array}$ & Total & \begin{tabular}{|c|} 
to \\
DOE \\
contractor
\end{tabular} & $\begin{array}{l}\text { to } \\
\text { others }\end{array}$ & \begin{tabular}{|l|} 
Total \\
samples
\end{tabular} & $\begin{array}{l}\text { Total } \\
\text { containers }\end{array}$ & $\begin{array}{l}\text { Print- } \\
\text { outs }\end{array}$ & \# & $\begin{array}{c}\text { limited } \\
\text { information } \\
\text { on \# samples }\end{array}$ & \begin{tabular}{|l} 
Total \\
requests
\end{tabular} \\
\hline $12 / 93$ & 25 & 19 & 6 & 3 & 1 & 2 & 28 & 42 & 42 & 11 & 2229 & 23 \\
\hline $3 / 94$ & 8 & 5 & 3 & 4 & 1 & 3 & 12 & 25 & 25 & 4 & 543 & 18 \\
\hline $6 / 94$ & 16 & 13 & 3 & 30 & 0 & 30 & 46 & 56 & 157 & 7 & 422 & 23 \\
\hline $9 / 94$ & 36 & 26 & 10 & 32 & 6 & 26 & 68 & 155 & 104 & 8 & 1268 & 31 \\
\hline $12 / 94$ & 19 & 19 & 0 & 1 & 0 & 1 & 20 & 26 & 66 & 5 & 215 & 16 \\
\hline $3 / 95$ & 25 & 14 & 11 & 12 & 5 & 7 & 37 & 68 & 150 & 19 & 2530 & 38 \\
\hline $6 / 95$ & 94 & 30 & 64 & 16 & 1 & 15 & 110 & 125 & 60 & 10 & 449 & 29 \\
\hline $9 / 95$ & 20 & 10 & 10 & 1 & 1 & 0 & 21 & 47 & 41 & 3 & 790 & 21 \\
\hline $12 / 95$ & 13 & 6 & 7 & 2 & 0 & 2 & 15 & 31 & 48 & 5 & 235 & 15 \\
\hline $3 / 96$ & 16 & 14 & 2 & 3 & 2 & 1 & 19 & 28 & 136 & 8 & 325 & 19 \\
\hline $6 / 96$ & 31 & 22 & 9 & 34 & 3 & 31 & 65 & 103 & 84 & 16 & 3826 & 30 \\
\hline $9 / 96$ & 24 & 17 & 7 & 2 & 0 & 2 & 26 & 48 & 41 & 10 & 2018 & 17 \\
\hline $12 / 96$ & 18 & 17 & 1 & 9 & 4 & 5 & 27 & 49 & 139 & 17 & 3289 & 27 \\
\hline $3 / 97$ & 25 & 14 & 11 & 6 & 4 & 2 & 31 & 34 & 177 & 10 & 2117 & 21 \\
\hline $6 / 97$ & 15 & 11 & 4 & 27 & 3 & 24 & 42 & 88 & 66 & 17 & 1765 & 23 \\
\hline $9 / 97$ & 27 & 15 & 12 & 106 & 95 & 11 & 133 & 143 & 291 & 15 & 4002 & 20 \\
\hline $12 / 97$ & 39 & 26 & 13 & 2 & 1 & 1 & 41 & 50 & 160 & 6 & 102 & 17 \\
\hline $3 / 98$ & 9 & 9 & 0 & 2 & 0 & 2 & 11 & 18 & 139 & 121 & 2549 & 34 \\
\hline $6 / 98$ & 19 & 10 & 9 & 0 & 0 & 0 & 19 & 47 & 90 & 20 & 416 & 30 \\
\hline $9 / 98$ & 29 & 10 & 19 & 16 & 0 & 16 & 45 & 85 & 101 & 4 & 1237 & 11 \\
\hline $12 / 98$ & 21 & 3 & 18 & 2 & 0 & 2 & 23 & 56 & 16 & 7 & 2507 & 19 \\
\hline $3 / 99$ & 25 & 2 & 23 & 0 & 0 & 0 & 25 & 29 & 18 & 30 & 1374 & 20 \\
\hline TOTAL & 554 & 312 & 242 & 307 & 127 & 181 & 836 & 1351 & 2109 & 353 & 34208 & 502 \\
\hline $\begin{array}{l}\text { TOTAL } \\
\text { including } \\
\text { DECS-17* }\end{array}$ & 570 & 328 & 242 & 307 & 127 & 181 & 852 & 1586 & 2109 & 353 & 34208 & 502 \\
\hline
\end{tabular}

*including 225 bags of DECS-17 (16 requests) 


\section{Task 2. The Coal Database}

\section{Task 2A. Programming}

Computer programming for the Coal Database was performed for three distinct computer platforms. First, in conjunction with the existing Watfile interactive database system running under VM/CMS on the Penn State mainframe, a program was completed to create printed reports in standard formats of four pages per sample or a condensed printout of one page per sample. Written in REXX, it read the Watfile database and created output in the Waterloo Script markup language for a mainframe-attached printer. This program was used throughout the contract to provide data printouts of DECS and PSOC samples. Other REXX programs were written to perform calculations of analytical data to a variety of bases of expression, and to provide other ancillary services for the Coal Database.

Late in the contract, support for the mainframe-attached printing system was discontinued, and discontinuation of the VM/CMS operating system was announced. The database structure was recreated in Microsoft Access 97 under the Windows 95 operating system, and the data were put in place. This system was in operation for queries and summaries of the database at the end of the contract. A format for printed reports, to replicate those from the earlier system, was under development at the end of the contract. The computerized inventory of sample containers was also transferred to Access 97, providing the possibility for linking it with the Coal Database if required.

During the contract, use of the world wide web on the Internet became widespread. Web pages were written describing the DOE Coal Sample Bank and Database and placed on a web server at http://www.ems.psu.edu/COPL/doesb.htm for access by the public. Penn State's College of Earth and Mineral Sciences provided programming services in CGI and Perl to create a searchable subset of the Database, including all 33 DECS samples, on the web. The URL during the contract was http://www.ems.psu.edu/COPL/coal.html but the pages were expected to be moved to the http://www.energyinstitute.psu.edu/ site during 1999.

\section{Task 2B. Data Entry}

Data for the 11 DECS samples collected under the contract were entered in the Coal Database as they became available from the analysts. Hazardous air pollutant trace element data for the 22 earlier DECS samples were also entered late in the contract.

\section{Task 2C. Distribution of Data to Users}

Data were distributed in a variety of formats. Standard four-page or one-page per sample data printouts were distributed individually in response to specific requests, alone or in conjunction with coal samples. A complete set of four-page per sample printouts for the 33 DECS samples was compiled and distributed to DOE contractors and grantees on request. Numbers of printouts distributed each quarter are shown in Table 12 (see Task 1I, above). Four-page printouts for the 11 DECS samples collected and analyzed under the contract are presented in Appendix D. 
The Database may be interactively queried to identify samples matching requestor's criteria. When a list of samples has been produced, a custom-formatted table of data may be created and printed, or the list of samples may be used to specify that a one-page or five-page data printout be produced for each sample. Subsets of the Database or formatted tables may also be transmitted in electronic form. Custom formatted reports or subsets and the number of sample records they contained are counted in Table 12 under "Special Data Requests"

The searchable data subset on the world wide web also delivered data to users in several formats (Table 13). A search performed through this system results in a table of samples meeting the criteria specified, and displaying several data fields. Each sample number in the table is a link to a more detailed page for that sample. In addition, there were many accesses of the brief table of DOE Coal Database data on the web site which are not counted here. This table was part of a printed brochure which was created and widely distributed during the contract to described the Coal Sample Bank and Database. Its contents are shown in Appendix E.

Table 13. Data delivered to users via the world wide web site

\begin{tabular}{|c|c|c|c|c|}
\hline year & month & $\begin{array}{c}\text { search } \\
\text { result } \\
\text { screens } \\
\text { presented }\end{array}$ & $\begin{array}{c}\text { individual } \\
\text { DECS } \\
\text { screens }\end{array}$ & $\begin{array}{c}\text { individua } \\
\text { PSOC } \\
\text { screens }\end{array}$ \\
\hline \multirow[t]{12}{*}{1998} & 1 & 39 & 1 & 6 \\
\hline & 2 & 132 & 10 & 110 \\
\hline & 3 & 69 & 8 & 71 \\
\hline & 4 & 70 & 64 & 1082 \\
\hline & 5 & 18 & 0 & 9 \\
\hline & 6 & 51 & 30 & 575 \\
\hline & 7 & 14 & 18 & 248 \\
\hline & 8 & 24 & 108 & 1041 \\
\hline & 9 & 17 & 15 & 245 \\
\hline & 10 & 76 & 1 & 30 \\
\hline & 11 & 63 & 3 & 82 \\
\hline & 12 & 13 & 41 & 109 \\
\hline \multirow[t]{3}{*}{1999} & 1 & 62 & 33 & 332 \\
\hline & 2 & 109 & 77 & 916 \\
\hline & 3 & 64 & 12 & 219 \\
\hline Total & & 821 & 421 & 5075 \\
\hline
\end{tabular}




\section{CONCLUSIONS}

The coal samples and data supported under this contract were used on an ongoing basis by a wide variety of DOE contractors and others performing coal research. Sample collection, processing, analysis, monitoring, and distribution have been completed as specified in the revised contract.

Thirty-three DECS samples are stored in argon under refrigeration in multilaminate bags. The succession of annual monitoring programs under this and the previous contract have demonstrated that this protocol preserves sample properties (thermoplastic behavior, sulfur forms, and calorific value) well over the evaluation period of up to nine years for some samples. These bags are inexpensive and can be employed with a minimum investment in supporting equipment, and should therefore be considered by researchers using coal samples over short or long time periods. Some samples did exhibit small degrees of deterioration; continued study to determine whether these are trends or random variation, and whether any trends might accelerate over longer time periods, would be valuable to coal researchers.

The DECS samples provide a well characterized set with a variety of properties suitable for laboratory research. A further benefit was their availability for immediate distribution at a variety of particle sizes and package sizes, all stored in the same manner: $2.3 \mathrm{~kg}$ of minus $6.4 \mathrm{~mm}(-1 / 4$ inch) coal, $300 \mathrm{~g}$ of minus $0.85 \mathrm{~mm}$ (-20 mesh U.S.) coal, and $75 \mathrm{~g}$ of minus $0.25 \mathrm{~mm}(-60 \mathrm{mesh}$ U.S.) coal.

Analytical data for these samples were obtained in a consistent manner and were widely distributed. A searchable data set was created on a world wide web site to provide data more efficiently to all interested parties. 


\section{REFERENCES}

ASTM, 1993, Annual Book of ASTM Standards, Gaseous Fuels; Coal and Coke, v. 05.05, ASTM, West Conshohocken, Penna., 536 pp.

Beier, E., 1983, Gas exchange of black coal and other substances when stored for decades in contact with air. In: Proc. 1983 Int. Conf. on Coal Science, Pittsburgh, PA, 15-19 Aug 1983, DE-8401399, Pittsburgh Energy Technology Center, p. 735-738.

Davidson, R.M., 1990, Natural Oxidation of Coal. IEACR/29, IEA Coal Research, London, 78 pp.

Davis, A., and Glick, D.C., 1993, Establishment and Maintenance of a Coal Sample Bank and Data Base. Final Report DOE/PC/79997--1 to U.S. Dept. Energy under Contract No. DERP22-87PC79997, 266 pp.

Dutcher, R.R., Gunter, M.M., Crelling, J.C., and Brower, W.E., 1985, Development of Techniques for Obtaining and Storing Premium Coal Samples. Final Report GRI-85/0008 to Gas Research Institute under Contract No. 5080-361-0419, 79 pp.

Harvey, R.D., and Kruse, C.W., 1988, The Illinois Basin Coal Sample Program: Status and Sample Characterization. J. Coal Qual., v. 7, no. 4, p. 109 - 113.

Hatcher, P.G., 1988. Dipolar-dephasing ${ }^{13} \mathrm{C}$ NMR studies of decomposed wood and coalified xylem tissue: evidence for chemical structural changes associated with defunctionalization of lignin structural units during coalification. Energy \& Fuels, v. 2, p. 40-58.

Hatcher, P.G., Faulon, J.-L., Wenzel, K.A., and Cody, G.D., 1992. A Structural Model for Lignin-Derived Vitrinite from High-Volatile Bituminous Coal (Coalified Wood). Energy \& Fuels, v. 6, p. 813-820.

Huffman, G.P, Huggins, F.E., Dunmyre, G.R., Pignocco, A.J., and Lin, M.-C., 1985, Comparative sensitivity of various analytical techniques to the low-temperature oxidation of coal. Fuel, v. 64 , p. $849-856$.

Huggins, F.E., and Huffman, G.P., 1989, Coal Weathering and Oxidation: The Early Stages. Ch. 2 in: Nelson, C.R. (Ed.), Chemistry of Coal Weathering. Coal Science and Technology 14. Elsevier, New York.

Kruse, C.W., 1989, personal communication.

Mitchell, G., and Davis, A., 1997, Surface Properties of Photo-Oxidized Bituminous Coals. Final Report DOE/PC/93223--14 to U.S. Dept. Energy under Grant No. DE-FG2293PC93223, 101 pp. 
Sharp, P.A., 1986, Storage of 8 Mesh Sub-bituminous Coal, J. Coal Qual., v. 5 no. 4, p. 131-132.

Smith, K.L., and Smoot, L.D., 1988, Selection and Characteristics of Standard ACERC Coals. Chemical Engineering Dept., Brigham Young Univ., Provo, Utah, 238 pp.

Vorres, K.S., 1989, personal communication.

Vorres, K.S., Kruse, C.W., Nater, K.A., Glick, D.C. and Davis, A., 1994, A Perspective on the Status of Coal Research from Shipments of Samples. Preprints Am. Chem. Soc., Division of Fuel Chem., 39, p. 1-6.

Wu, M.M., Robbins, G.L., Winschel, R.A., and Burke, F.P., 1988, Low-Temperature Coal Weathering: Its Chemical Nature and Effects on Coal Properties. Energy \& Fuels, v. 2, p. $150-157$. 
APPENDIX A. Monitoring of DECS Coals to Evaluate Sample Condition after Storage

\begin{tabular}{|c|c|c|c|c|c|c|}
\hline unnamed seam & & & lig & Ro $m$ & $x=0.35$ & \\
\hline $\begin{array}{l}\text { FOIL BAG } \\
\text { particle size stored } \\
\text { note } \\
\text { date sealed } \\
\text { date analyzed }\end{array}$ & $\begin{array}{l}\text { original } \\
\text { analysis }\end{array}$ & $\begin{array}{l}22 \text { of } 256 \\
-20 \text { mesh } \\
8 / 14 / 90 \\
1 / 25 / 91 \\
\end{array}$ & $\begin{array}{r}93 \text { of } 256 \\
-20 \text { mesh } \\
8 / 14 / 90 \\
10 / 01 / 92 \\
\end{array}$ & $\begin{array}{r}113 \text { of } 256 \\
-20 \text { mesh } \\
8 / 14 / 90 \\
6 / 14 / 93 \\
\end{array}$ & $\begin{array}{l}109 \text { of } 256 \\
-20 \text { mesh } \\
8 / 14 / 90 \\
3 / 23 / 94 \\
\end{array}$ & $\begin{array}{l}62 \text { of } 256 \\
-20 \text { mesh } \\
8 / 14 / 90 \\
3 / 17 / 99 \\
\end{array}$ \\
\hline $\begin{array}{l}\text { PROXIMATE } \\
\% \text { moisture } \\
\% \text { ash (dry basis) } \\
\end{array}$ & $\begin{array}{l}30.0 \\
15.8 \\
\end{array}$ & $\begin{array}{l}28.2 \\
16.2 \\
\end{array}$ & $\begin{array}{l}29.0 \\
15.2 \\
\end{array}$ & $\begin{array}{l}29.3 \\
16.4 \\
\end{array}$ & $\begin{array}{l}29.6 \\
16.4 \\
\end{array}$ & $\begin{array}{l}29.8 \\
15.9 \\
\end{array}$ \\
\hline $\begin{array}{l}\text { SULFUR FORMS (dry \%) } \\
\text { total sulfur } \\
\text { sulfate } \\
\text { pyritic } \\
\text { organic } \\
\end{array}$ & $\begin{array}{l}0.99 \\
0.01 \\
0.11 \\
0.86 \\
\end{array}$ & $\begin{array}{l}1.03 \\
0.06 \\
0.13 \\
0.85 \\
\end{array}$ & $\begin{array}{l}0.97 \\
0.00 \\
0.11 \\
0.86 \\
\end{array}$ & $\begin{array}{l}1.07 \\
0.00 \\
0.13 \\
0.94 \\
\end{array}$ & $\begin{array}{l}1.08 \\
0.00 \\
0.11 \\
0.96 \\
\end{array}$ & $\begin{array}{l}1.10 \\
0.01 \\
0.23 \\
0.86 \\
\end{array}$ \\
\hline $\begin{array}{l}\text { CALORIFIC VALUE (dry) } \\
\text { Btu/lb }\end{array}$ & 10956 & 10791 & 11023 & 10912 & 10941 & 11009 \\
\hline $\begin{array}{l}\text { GASEOUS OXYGEN } \\
\% \text { in bag atmosphere } \\
\text { date analyzed }\end{array}$ & & & & & $\begin{array}{c}0.00 \\
3 / 08 / 94\end{array}$ & $\begin{array}{c}\text { Not } \\
\text { determined }\end{array}$ \\
\hline
\end{tabular}


APPENDIX A. Monitoring of DECS Coals to Evaluate Sample Condition after Storage

\begin{tabular}{|c|c|c|c|c|c|c|c|c|c|c|}
\hline DECS-2 & Illinois \#6 & seam & & & $\mathrm{hvCb}$ & & & & Ro $\max =$ & $0.52 \%$ \\
\hline $\begin{array}{l}\text { FOIL BAG } \\
\text { particle size stored } \\
\text { note } \\
\text { date sealed } \\
\text { date analyzed }\end{array}$ & $\begin{array}{l}\text { original } \\
\text { analysis }\end{array}$ & $\begin{array}{l}21 \text { of } 256 \\
-20 \text { mesh } \\
8 / 06 / 90 \\
1 / 25 / 91\end{array}$ & $\begin{array}{r}100 \text { of } 256 \\
-20 \text { mesh } \\
8 / 06 / 90 \\
11 / 27 / 92 \\
\end{array}$ & $\begin{array}{l}109 \text { of } 256 \\
-20 \text { mesh } \\
8 / 06 / 90 \\
6 / 14 / 93 \\
\end{array}$ & $\begin{array}{r}114 \text { of } 256 \\
115 \text { of } 256 \\
-20 \text { mesh } \\
\\
8 / 06 / 90 \\
3 / 23 / 94 \\
\end{array}$ & $\begin{array}{l}136 \text { of } 256 \\
-20 \text { mesh } \\
8 / 06 / 90 \\
5 / 23 / 95 \\
\end{array}$ & $\begin{array}{l}138 \text { of } 256 \\
-20 \text { mesh } \\
8 / 06 / 90 \\
2 / 13 / 96 \\
\end{array}$ & $\begin{array}{l}152 \text { of } 256 \\
-20 \text { mesh } \\
8 / 06 / 90 \\
7 / 31 / 97 \\
\end{array}$ & $\begin{array}{l}155 \text { of } 256 \\
-20 \text { mesh } \\
8 / 06 / 90 \\
7 / 28 / 98 \\
\end{array}$ & $\begin{array}{l}154 \text { of } 1256 \\
-20 \text { mesh } \\
8 / 06 / 90 \\
3 / 12 / 99 \\
\end{array}$ \\
\hline $\begin{array}{l}\text { PROXIMATE } \\
\% \text { moisture } \\
\% \text { ash (dry basis) } \\
\end{array}$ & $\begin{array}{l}10.4 \\
16.2 \\
\end{array}$ & $\begin{array}{l}10.3 \\
16.1 \\
\end{array}$ & $\begin{array}{l}10.1 \\
16.2 \\
\end{array}$ & $\begin{array}{c}9.8 \\
15.9 \\
\end{array}$ & $\begin{array}{c}9.6 \\
16.1 \\
\end{array}$ & $\begin{array}{l}10.2 \\
15.9 \\
\end{array}$ & $\begin{array}{l}10.0 \\
16.0\end{array}$ & $\begin{array}{l}10.2 \\
16.1 \\
\end{array}$ & $\begin{array}{r}9.9 \\
16.3 \\
\end{array}$ & $\begin{array}{l}10.2 \\
15.9 \\
\end{array}$ \\
\hline $\begin{array}{l}\text { SULFUR FORMS (dry \%) } \\
\text { total sulfur } \\
\text { sulfate } \\
\text { pyritic } \\
\text { organic } \\
\end{array}$ & $\begin{array}{l}4.51 \\
0.01 \\
2.27 \\
2.24 \\
\end{array}$ & $\begin{array}{l}4.33 \\
0.06 \\
2.27 \\
2.00 \\
\end{array}$ & $\begin{array}{l}4.54 \\
0.01 \\
2.31 \\
2.22 \\
\end{array}$ & $\begin{array}{l}4.50 \\
0.03 \\
2.06 \\
2.41 \\
\end{array}$ & $\begin{array}{l}4.64 \\
0.01 \\
1.92 \\
2.72 \\
\end{array}$ & $\begin{array}{l}4.62 \\
0.04 \\
2.06 \\
2.51 \\
\end{array}$ & $\begin{array}{l}4.59 \\
0.01 \\
2.27 \\
2.30 \\
\end{array}$ & $\begin{array}{l}4.63 \\
0.07 \\
2.35 \\
2.21 \\
\end{array}$ & $\begin{array}{l}4.78 \\
0.03 \\
2.46 \\
2.29 \\
\end{array}$ & $\begin{array}{l}4.67 \\
0.01 \\
2.57 \\
2.10\end{array}$ \\
\hline $\begin{array}{l}\text { CALORIFIC VALUE (dry) } \\
\text { Btu/lb }\end{array}$ & 11880 & 11740 & 11814 & 11787 & 11895 & 11833 & 11813 & 11794 & 11752 & 11802 \\
\hline $\begin{array}{l}\text { GIESELER FLUIDITY } \\
\text { maximum fluidity, ddpm } \\
\text { fluid range, }{ }^{\circ} \mathrm{C} \\
\text { date analyzed } \\
\text { FREE SWELLING INDEX }\end{array}$ & $\begin{array}{c}8 \\
47 \\
2 / 08 / 90 \\
3.5 \\
\end{array}$ & \begin{tabular}{c}
\multicolumn{1}{c}{9} \\
\multicolumn{5}{c}{58} \\
2/ $11 / 91$
\end{tabular} & $\begin{array}{c}10 \\
61 \\
2 / 02 / 93\end{array}$ & $\begin{array}{c}7 \\
55 \\
7 / 19 / 93\end{array}$ & $\begin{array}{c}8 \\
63 \\
3 / 07 / 94 \\
3.5 \\
\end{array}$ & $\begin{array}{c}11 \\
64 \\
5 / 09 / 95 \\
3.5 \\
\end{array}$ & $\begin{array}{c}9 \\
58 \\
1 / 23 / 96 \\
2.5 \\
\end{array}$ & $\begin{array}{c}6 \\
57 \\
7 / 22 / 97 \\
3 \\
\end{array}$ & $\begin{array}{c}12 \\
54 \\
7 / 02 / 98 \\
5 \\
\end{array}$ & $\begin{array}{c}\text { Not } \\
\text { determined }\end{array}$ \\
\hline $\begin{array}{l}\text { GASEOUS OXYGEN } \\
\% \text { in bag atmosphere } \\
\text { date analyzed }\end{array}$ & & & & & $\begin{array}{c}0.12 \\
3 / 08 / 94\end{array}$ & $\begin{array}{c}0.00 \\
5 / 09 / 95\end{array}$ & $\begin{array}{c}0.17 \\
1 / 18 / 96\end{array}$ & $\begin{array}{c}0.08 \\
7 / 21 / 97\end{array}$ & $\begin{array}{c}\text { (a) } \\
0.00 \\
7 / 01 / 98\end{array}$ & $\begin{array}{c}\text { Not } \\
\text { determined }\end{array}$ \\
\hline
\end{tabular}

(a) less than usual accuracy but definitely no significant oxygen 
APPENDIX A. Monitoring of DECS Coals to Evaluate Sample Condition after Storage

\begin{tabular}{|c|c|c|c|c|c|c|}
\hline Coal Basin M & seam & & $\mathrm{mvb}$ & Ro $\max$ & 1.28 & \\
\hline $\begin{array}{l}\text { FOIL BAG } \\
\text { particle size stored } \\
\text { note } \\
\text { date sealed } \\
\text { date analyzed }\end{array}$ & $\begin{array}{l}\text { original } \\
\text { analysis }\end{array}$ & $\begin{array}{l}5 \text { of } 256 \\
-20 \text { mesh } \\
8 / 24 / 90 \\
1 / 25 / 91 \\
\end{array}$ & $\begin{array}{r}13 \text { of } 256 \\
-20 \text { mesh } \\
8 / 24 / 90 \\
11 / 27 / 92 \\
\end{array}$ & $\begin{array}{c}31 \text { of } 256 \\
-20 \text { mesh } \\
8 / 24 / 90 \\
6 / 14 / 93 \\
\end{array}$ & $\begin{array}{l}15 \text { of } 256 \\
-20 \text { mesh } \\
8 / 24 / 90 \\
3 / 23 / 94 \\
\end{array}$ & $\begin{array}{c}20 \text { of } 256 \\
-20 \text { mesh } \\
8 / 24 / 90 \\
3 / 16 / 99 \\
\end{array}$ \\
\hline $\begin{array}{l}\text { PROXIMATE } \\
\% \text { moisture } \\
\% \text { ash (dry basis) } \\
\end{array}$ & $\begin{array}{l}1.10 \\
5.37 \\
\end{array}$ & $\begin{array}{l}0.87 \\
5.24 \\
\end{array}$ & $\begin{array}{l}0.82 \\
5.26 \\
\end{array}$ & $\begin{array}{l}0.72 \\
5.52 \\
\end{array}$ & $\begin{array}{l}1.01 \\
5.22 \\
\end{array}$ & $\begin{array}{l}1.02 \\
5.15\end{array}$ \\
\hline $\begin{array}{l}\text { SULFUR FORMS (dry \%) } \\
\text { total sulfur } \\
\text { sulfate } \\
\text { pyritic } \\
\text { organic } \\
\end{array}$ & $\begin{array}{l}0.65 \\
0.01 \\
0.10 \\
0.54 \\
\end{array}$ & $\begin{array}{l}0.65 \\
0.05 \\
0.08 \\
0.52 \\
\end{array}$ & $\begin{array}{l}0.67 \\
0.01 \\
0.05 \\
0.61 \\
\end{array}$ & $\begin{array}{l}0.64 \\
0.05 \\
0.05 \\
0.55 \\
\end{array}$ & $\begin{array}{l}0.64 \\
0.01 \\
0.07 \\
0.56 \\
\end{array}$ & $\begin{array}{l}0.65 \\
0.00 \\
0.20 \\
0.44 \\
\end{array}$ \\
\hline $\begin{array}{l}\text { CALORIFIC VALUE (dry) } \\
\text { Btu/lb }\end{array}$ & 14889 & 14907 & 14797 & 14828 & 14956 & 15023 \\
\hline $\begin{array}{l}\text { GIESELER FLUIDITY } \\
\text { maximum fluidity, ddpm } \\
\text { fluid range, }{ }^{\circ} \mathrm{C} \\
\text { date analyzed } \\
\text { FREE SWELLING INDEX } \\
\end{array}$ & $\begin{array}{r}9774 \\
100 \\
7 / 11 / 90 \\
9 \\
\end{array}$ & $\begin{array}{c}17(a) \\
79 \\
11 / 06 / 91\end{array}$ & $\begin{array}{c}383(b) \\
94 \\
11 / 27 / 92\end{array}$ & $\begin{array}{c}234 \\
94 \\
7 / 20 / 93\end{array}$ & $\begin{array}{r}1354 \\
111 \\
3 / 08 / 94 \\
9 \\
\end{array}$ & $\begin{array}{c}\text { Not } \\
\text { determined }\end{array}$ \\
\hline $\begin{array}{l}\text { GASEOUS OXYGEN } \\
\% \text { in bag atmosphere } \\
\text { date analyzed }\end{array}$ & & & & & $\begin{array}{l}0.05 \\
3 / 08 / 94\end{array}$ & $\begin{array}{c}\text { Not } \\
\text { determined }\end{array}$ \\
\hline
\end{tabular}

(a) erratic behavior during testing (3 runs performed)

(b) erratic behavior during testing (6 runs performed) 


\begin{tabular}{|c|c|c|c|c|}
\hline Blue seam & & $\mathrm{vCb}$ & Ro $\max =$ & .51 \\
\hline $\begin{array}{l}\text { FOIL BAG } \\
\text { particle size stored } \\
\text { note } \\
\text { date sealed } \\
\text { date analyzed }\end{array}$ & $\begin{array}{l}\text { original } \\
\text { analysis }\end{array}$ & $\begin{array}{l}6 \text { of } 256 \\
-20 \text { mesh } \\
9 / 27 / 90 \\
11 / 27 / 92 \\
\end{array}$ & $\begin{array}{l}16 \text { of } 256 \\
-20 \text { mesh } \\
9 / 27 / 90 \\
6 / 03 / 93 \\
\end{array}$ & $\begin{array}{c}11 \text { of } 256 \\
-20 \text { mesh } \\
9 / 27 / 90 \\
3 / 23 / 94 \\
\end{array}$ \\
\hline $\begin{array}{l}\text { PROXIMATE } \\
\% \text { moisture } \\
\% \text { ash (dry basis) }\end{array}$ & $\begin{array}{r}15.1 \\
6.2 \\
\end{array}$ & $\begin{array}{r}15.0 \\
6.2 \\
\end{array}$ & $\begin{array}{r}14.8 \\
6.2 \\
\end{array}$ & $\begin{array}{r}15.2 \\
6.0 \\
\end{array}$ \\
\hline $\begin{array}{l}\text { SULFUR FORMS (dry \%) } \\
\text { total sulfur } \\
\text { sulfate } \\
\text { pyritic } \\
\text { organic } \\
\end{array}$ & $\begin{array}{l}0.46 \\
0.02 \\
0.04 \\
0.41 \\
\end{array}$ & $\begin{array}{l}0.57 \\
0.00 \\
0.04 \\
0.52 \\
\end{array}$ & $\begin{array}{l}0.54 \\
0.00 \\
0.04 \\
0.50 \\
\end{array}$ & $\begin{array}{l}0.54 \\
0.01 \\
0.04 \\
0.50 \\
\end{array}$ \\
\hline $\begin{array}{l}\text { CALORIFIC VALUE (dry) } \\
\text { Btu/lb }\end{array}$ & 13000 & 12919 & 12964 & 13053 \\
\hline $\begin{array}{l}\text { GIESELER FLUIDITY } \\
\text { maximum fluidity, ddpm } \\
\text { fluid range, }{ }^{\circ} \mathrm{C} \\
\text { date analyzed } \\
\text { FREE SWELLING INDEX }\end{array}$ & $\begin{aligned} & 0 \\
& 0 \\
& 2 / 12 / 91 \\
& 0.5 \\
&\end{aligned}$ & $\begin{array}{r}0 \\
0 \\
2 / 02 / 93\end{array}$ & $\begin{array}{r}0 \\
0 \\
7 / 21 / 93\end{array}$ & $\begin{array}{l}\text { discon- } \\
\text { tinued }\end{array}$ \\
\hline $\begin{array}{l}\text { GASEOUS OXYGEN } \\
\% \text { in bag atmosphere } \\
\text { date analyzed }\end{array}$ & & & & $\begin{array}{r}0.00 \\
3 / 08 / 94\end{array}$ \\
\hline
\end{tabular}


APPENDIX A. Monitoring of DECS Coals to Evaluate Sample Condition after Storage

\begin{tabular}{|c|c|c|c|c|c|}
\hline Hiawatha seam & & & $\mathrm{hvCb}$ & Ro $\max =$ & 0.59 \\
\hline $\begin{array}{l}\text { FOIL BAG } \\
\text { particle size stored } \\
\text { note } \\
\text { date sealed } \\
\text { date analyzed }\end{array}$ & $\begin{array}{l}\text { original } \\
\text { analysis }\end{array}$ & $\begin{array}{l}11 \text { of } 256 \\
-20 \text { mesh } \\
9 / 07 / 90 \\
10 / 02 / 92\end{array}$ & $\begin{array}{l}32 \text { of } 256 \\
-20 \text { mesh } \\
9 / 07 / 90 \\
6 / 14 / 93\end{array}$ & $\begin{array}{l}14 \text { of } 256 \\
-20 \text { mesh } \\
9 / 07 / 90 \\
3 / 23 / 94\end{array}$ & $\begin{array}{l}18 \text { of } 256 \\
-20 \text { mesh } \\
9 / 07 / 90 \\
3 / 17 / 99\end{array}$ \\
\hline $\begin{array}{l}\text { PROXIMATE } \\
\% \text { moisture } \\
\% \text { ash (dry basis) }\end{array}$ & $\begin{array}{l}7.5 \\
8.5 \\
\end{array}$ & $\begin{array}{l}7.3 \\
8.7\end{array}$ & $\begin{array}{l}7.1 \\
8.7\end{array}$ & $\begin{array}{l}7.2 \\
8.7\end{array}$ & $\begin{array}{l}7.4 \\
8.6\end{array}$ \\
\hline $\begin{array}{l}\text { SULFUR FORMS (dry \%) } \\
\text { total sulfur } \\
\text { sulfate } \\
\text { pyritic } \\
\text { organic } \\
\end{array}$ & $\begin{array}{l}0.56 \\
0.01 \\
0.27 \\
0.28 \\
\end{array}$ & $\begin{array}{l}0.63 \\
0.01 \\
0.26 \\
0.35 \\
\end{array}$ & $\begin{array}{l}0.67 \\
0.01 \\
0.24 \\
0.42 \\
\end{array}$ & $\begin{array}{l}0.64 \\
0.00 \\
0.24 \\
0.40 \\
\end{array}$ & $\begin{array}{l}0.64 \\
0.01 \\
0.36 \\
0.27 \\
\end{array}$ \\
\hline $\begin{array}{l}\text { CALORIFIC VALUE (dry) } \\
\text { Btu/lb }\end{array}$ & 12760 & 12681 & 12723 & 12784 & 12833 \\
\hline $\begin{array}{l}\text { GASEOUS OXYGEN } \\
\% \text { in bag atmosphere } \\
\text { date analyzed }\end{array}$ & & & & $\begin{array}{c}0.00 \\
3 / 08 / 94\end{array}$ & $\begin{array}{c}\text { Not } \\
\text { determined }\end{array}$ \\
\hline
\end{tabular}




\begin{tabular}{|c|c|c|c|c|c|}
\hline \multicolumn{2}{|c|}{ Blind Canyon seam } & \multicolumn{2}{|r|}{ hvAb } & \multicolumn{2}{|c|}{ Ro $\max =0.66$} \\
\hline $\begin{array}{l}\text { FOIL BAG } \\
\text { particle size stored } \\
\text { note } \\
\text { date sealed } \\
\text { date analyzed }\end{array}$ & $\begin{array}{l}\text { original } \\
\text { analysis }\end{array}$ & $\begin{array}{l}12 \text { of } 256 \\
-20 \text { mesh } \\
7 / 19 / 90 \\
1 / 25 / 91 \\
\end{array}$ & $\begin{array}{c}107 \text { of } 256 \\
-20 \text { mesh } \\
7 / 19 / 90 \\
10 / 21 / 92 \\
\end{array}$ & $\begin{array}{c}125 \text { of } 256 \\
-20 \text { mesh } \\
7 / 19 / 90 \\
6 / 23 / 93 \\
\end{array}$ & $\begin{array}{r}128 \text { of } 256 \\
-20 \text { mesh } \\
7 / 19 / 90 \\
3 / 23 / 94 \\
\end{array}$ \\
\hline $\begin{array}{l}\text { PROXIMATE } \\
\% \text { moisture } \\
\% \text { ash (dry basis) }\end{array}$ & $\begin{array}{l}4.73 \\
5.84\end{array}$ & $\begin{array}{l}4.35 \\
5.96 \\
\end{array}$ & $\begin{array}{l}4.06 \\
5.92 \\
\end{array}$ & $\begin{array}{l}4.45 \\
6.00 \\
\end{array}$ & $\begin{array}{l}4.42 \\
6.04 \\
\end{array}$ \\
\hline $\begin{array}{l}\text { SULFUR FORMS (dry \%) } \\
\text { total sulfur } \\
\text { sulfate } \\
\text { pyritic } \\
\text { organic }\end{array}$ & $\begin{array}{l}0.40 \\
0.01 \\
0.02 \\
0.37 \\
\end{array}$ & $\begin{array}{l}0.43 \\
0.03 \\
0.02 \\
0.38 \\
\end{array}$ & $\begin{array}{l}0.35 \\
0.00 \\
0.02 \\
0.33 \\
\end{array}$ & $\begin{array}{l}0.43 \\
0.01 \\
0.02 \\
0.40 \\
\end{array}$ & $\begin{array}{l}0.42 \\
0.02 \\
0.02 \\
0.40 \\
\end{array}$ \\
\hline $\begin{array}{l}\text { CALORIFIC VALUE (dry) } \\
\text { Btu/lb }\end{array}$ & 13923 & 13828 & 13814 & 13874 & 13920 \\
\hline $\begin{array}{l}\text { GIESELER FLUIDITY } \\
\text { maximum fluidity, ddpm } \\
\text { fluid range, }{ }^{\circ} \mathrm{C} \\
\text { date analyzed }\end{array}$ & $\begin{array}{r}3 \\
38 \\
2 / 14 / 91 \\
\end{array}$ & $\begin{array}{r}0 \\
0 \\
11 / 04 / 91 \\
\end{array}$ & discontinued & & \\
\hline $\begin{array}{l}\text { GASEOUS OXYGEN } \\
\% \text { in bag atmosphere } \\
\text { date analyzed }\end{array}$ & & & & & $\begin{array}{c}0.06 \\
3 / 08 / 94 \\
\end{array}$ \\
\hline
\end{tabular}


APPENDIX A. Monitoring of DECS Coals to Evaluate Sample Condition after Storage

\begin{tabular}{|c|c|c|c|c|}
\hline \multicolumn{2}{|c|}{ Adaville \#1 seam } & $\mathrm{hvCb}$ & \multicolumn{2}{|c|}{ Ro $\max =0.45$} \\
\hline $\begin{array}{l}\text { FOIL BAG } \\
\text { particle size stored } \\
\text { note } \\
\text { date sealed } \\
\text { date analyzed }\end{array}$ & $\begin{array}{l}\text { original } \\
\text { analysis }\end{array}$ & $\begin{array}{l}21 \text { of } 256 \\
-20 \text { mesh } \\
12 / 10 / 90 \\
10 / 15 / 92 \\
\end{array}$ & $\begin{array}{l}26 \text { of } 256 \\
-20 \text { mesh } \\
12 / 10 / 90 \\
6 / 03 / 93 \\
\end{array}$ & $\begin{array}{l}28 \text { of } 256 \\
-20 \text { mesh } \\
12 / 10 / 90 \\
3 / 23 / 94 \\
\end{array}$ \\
\hline $\begin{array}{l}\text { PROXIMATE } \\
\% \text { moisture } \\
\% \text { ash (dry basis) }\end{array}$ & $\begin{array}{l}17.3 \\
4.2 \\
\end{array}$ & $\begin{array}{r}16.8 \\
4.3 \\
\end{array}$ & $\begin{array}{c}17.0 \\
4.3 \\
\end{array}$ & $\begin{array}{r}17.1 \\
4.2 \\
\end{array}$ \\
\hline $\begin{array}{l}\text { SULFUR FORMS (dry \%) } \\
\text { total sulfur } \\
\text { sulfate } \\
\text { pyritic } \\
\text { organic } \\
\end{array}$ & $\begin{array}{l}0.98 \\
0.01 \\
0.10 \\
0.87 \\
\end{array}$ & $\begin{array}{l}0.99 \\
0.01 \\
0.08 \\
0.90 \\
\end{array}$ & $\begin{array}{l}1.04 \\
0.01 \\
0.08 \\
0.94 \\
\end{array}$ & $\begin{array}{l}1.03 \\
0.00 \\
0.08 \\
0.94 \\
\end{array}$ \\
\hline $\begin{array}{l}\text { CALORIFIC VALUE (dry) } \\
\text { Btu/lb }\end{array}$ & 13068 & 12898 & 12947 & 12988 \\
\hline $\begin{array}{l}\text { GASEOUS OXYGEN } \\
\% \text { in bag atmosphere } \\
\text { date analyzed }\end{array}$ & & & & $\begin{array}{c}0.08 \\
3 / 08 / 94\end{array}$ \\
\hline
\end{tabular}




\begin{tabular}{|c|c|c|c|c|c|c|c|c|c|}
\hline \multirow[b]{2}{*}{$\begin{array}{l}\text { DECS-8 } \\
\text { FOIL BAG } \\
\text { particle size stored } \\
\text { note } \\
\text { date sealed } \\
\text { date analyzed }\end{array}$} & \multicolumn{3}{|c|}{ Smith-Roland seam } & \multicolumn{2}{|l|}{ subC } & & \multicolumn{3}{|c|}{ Ro $\max =0.37 \%$} \\
\hline & $\begin{array}{l}\text { original } \\
\text { analysis } \\
10 / 30 / 90 \\
\end{array}$ & $\begin{array}{l}27 \text { of } 256 \\
-20 \text { mesh } \\
10 / 22 / 90 \\
10 / 21 / 92 \\
\end{array}$ & $\begin{array}{c}127 \text { of } 256 \\
-20 \text { mesh } \\
10 / 22 / 90 \\
6 / 03 / 93 \\
\end{array}$ & $\begin{array}{l}138 \text { of } 256 \\
-20 \text { mesh } \\
10 / 22 / 90 \\
3 / 23 / 94 \\
\end{array}$ & $\begin{array}{c}144 \text { of } 256 \\
-20 \text { mesh } \\
10 / 22 / 90 \\
5 / 09 / 95 \\
\end{array}$ & $\begin{array}{c}159 \text { of } 256 \\
-20 \text { mesh } \\
10 / 22 / 96 \\
2 / 13 / 96 \\
\end{array}$ & $\begin{array}{r}65 \text { of } 256 \\
-20 \text { mesh } \\
10 / 22 / 90 \\
8 / 01 / 97 \\
\end{array}$ & $\begin{array}{l}71 \text { of } 256 \\
-20 \text { mesh } \\
10 / 22 / 90 \\
7 / 28 / 98 \\
\end{array}$ & $\begin{array}{l}72 \text { of } 256 \\
-20 \text { mesh } \\
10 / 22 / 90 \\
3 / 17 / 99 \\
\end{array}$ \\
\hline $\begin{array}{l}\text { PROXIMATE } \\
\% \text { moisture } \\
\% \text { ash (dry basis) }\end{array}$ & $\begin{array}{l}28.4 \\
13.8 \\
\end{array}$ & $\begin{array}{l}28.3 \\
12.8 \\
\end{array}$ & $\begin{array}{l}28.6 \\
13.1 \\
\end{array}$ & $\begin{array}{l}28.1 \\
13.0 \\
\end{array}$ & $\begin{array}{l}28.6 \\
13.6 \\
\end{array}$ & $\begin{array}{l}28.7 \\
13.0 \\
\end{array}$ & $\begin{array}{l}28.6 \\
13.1 \\
\end{array}$ & $\begin{array}{l}28.9 \\
13.0 \\
\end{array}$ & $\begin{array}{l}28.7 \\
12.9 \\
\end{array}$ \\
\hline $\begin{array}{l}\text { SULFUR FORMS (dry \%) } \\
\text { total sulfur } \\
\text { sulfate } \\
\text { pyritic } \\
\text { organic } \\
\end{array}$ & $\begin{array}{l}0.73 \\
0.02 \\
0.28 \\
0.43 \\
\end{array}$ & $\begin{array}{l}0.77 \\
0.01 \\
0.20 \\
0.56 \\
\end{array}$ & $\begin{array}{l}0.81 \\
0.01 \\
0.22 \\
0.58 \\
\end{array}$ & $\begin{array}{l}0.95 \\
0.00 \\
0.22 \\
0.72 \\
\end{array}$ & $\begin{array}{l}0.87 \\
0.01 \\
0.27 \\
0.58 \\
\end{array}$ & $\begin{array}{l}0.80 \\
0.01 \\
0.25 \\
0.54 \\
\end{array}$ & $\begin{array}{l}0.78 \\
0.00 \\
0.31 \\
0.47 \\
\end{array}$ & $\begin{array}{l}0.82 \\
0.01 \\
0.31 \\
0.50 \\
\end{array}$ & $\begin{array}{l}0.79 \\
0.01 \\
0.29 \\
0.48 \\
\end{array}$ \\
\hline $\begin{array}{l}\text { CALORIFIC VALUE (dry) } \\
\text { Btu/lb }\end{array}$ & 11168 & 11275 & 11287 & 11244 & 11210 & $\begin{array}{c}(a) \\
11263 \\
\end{array}$ & 11223 & 11215 & $\begin{array}{c}\text { Not } \\
\text { determined }\end{array}$ \\
\hline $\begin{array}{l}\text { GASEOUS OXYGEN } \\
\% \text { in bag atmosphere } \\
\text { date analyzed }\end{array}$ & & & & $\begin{array}{c}0.08 \\
3 / 08 / 94 \\
\end{array}$ & $\begin{array}{c}0.14 \\
5 / 09 / 95 \\
\end{array}$ & $\begin{array}{c}0.28 \\
1 / 18 / 96 \\
\end{array}$ & $\begin{array}{c}0.13 \\
7 / 21 / 97 \\
\end{array}$ & $\begin{aligned} &(\mathrm{b}) \\
& 0.00 \\
& 7 / 02 / 98 \\
&\end{aligned}$ & $\begin{array}{c}\text { Not } \\
\text { determined }\end{array}$ \\
\hline
\end{tabular}

(a) result from repeat analysis 4/29/96, change from Quarterly Technical Progress Report dated 4/25/96.

(b) less than usual accuracy but definitely no significant oxygen 
APPENDIX A. Monitoring of DECS Coals to Evaluate Sample Condition after Storage

\begin{tabular}{|c|c|c|c|c|}
\hline Dietz seam & & subB & Ro $\mathrm{m}$ & $=0.38$ \\
\hline $\begin{array}{l}\text { FOIL BAG } \\
\text { particle size stored } \\
\text { note } \\
\text { date sealed } \\
\text { date analyzed }\end{array}$ & $\begin{array}{l}\text { original } \\
\text { analysis }\end{array}$ & $\begin{array}{l}\text { of } 256 \\
\begin{array}{r}-20 \text { mesh } \\
1 / 10 / 91 \\
10 / 21 / 92\end{array}\end{array}$ & $\begin{array}{l}\text { of } 256 \\
\begin{array}{l}-20 \text { mesh } \\
1 / 10 / 91 \\
6 / 03 / 93\end{array}\end{array}$ & $\begin{array}{l}\text { of } 256 \\
\begin{array}{l}-20 \text { mesh } \\
1 / 10 / 91 \\
3 / 23 / 94\end{array}\end{array}$ \\
\hline $\begin{array}{l}\text { PROXIMATE } \\
\% \text { moisture } \\
\% \text { ash (dry basis) }\end{array}$ & $\begin{array}{r}24.7 \\
6.4 \\
\end{array}$ & $\begin{array}{r}23.8 \\
6.7 \\
\end{array}$ & $\begin{array}{r}24.8 \\
6.5 \\
\end{array}$ & $\begin{array}{r}24.6 \\
6.3 \\
\end{array}$ \\
\hline $\begin{array}{l}\text { SULFUR FORMS (dry \%) } \\
\text { total sulfur } \\
\text { sulfate } \\
\text { pyritic } \\
\text { organic } \\
\end{array}$ & $\begin{array}{l}0.41 \\
0.02 \\
0.08 \\
0.31\end{array}$ & $\begin{array}{l}0.42 \\
0.03 \\
0.06 \\
0.33 \\
\end{array}$ & $\begin{array}{l}0.44 \\
0.03 \\
0.05 \\
0.35\end{array}$ & $\begin{array}{l}0.42 \\
0.01 \\
0.05 \\
0.36\end{array}$ \\
\hline $\begin{array}{l}\text { CALORIFIC VALUE (dry) } \\
\text { Btu/lb }\end{array}$ & 12330 & 12230 & 12401 & 12313 \\
\hline $\begin{array}{l}\text { GASEOUS OXYGEN } \\
\% \text { in bag atmosphere } \\
\text { date analyzed }\end{array}$ & & & & $\begin{array}{ll} & 0.03 \\
3 / 08 / 94\end{array}$ \\
\hline
\end{tabular}




\begin{tabular}{|c|c|c|c|c|c|}
\hline Rosebud seam & & & subB & Ro $m$ & $x=0.42$ \\
\hline $\begin{array}{l}\text { FOIL BAG } \\
\text { particle size stored } \\
\text { note } \\
\text { date sealed } \\
\text { date analyzed }\end{array}$ & $\begin{array}{l}\text { original } \\
\text { analysis }\end{array}$ & $\begin{array}{l}8 \text { of } 256 \\
-20 \text { mesh } \\
1 / 18 / 91 \\
10 / 15 / 92 \\
\end{array}$ & $\begin{array}{l}27 \text { of } 256 \\
-20 \text { mesh } \\
1 / 18 / 91 \\
6 / 04 / 93 \\
\end{array}$ & $\begin{array}{r}10 \text { of } 256 \\
-20 \text { mesh } \\
1 / 18 / 91 \\
3 / 23 / 94 \\
\end{array}$ & $\begin{array}{c}28 \text { of } 256 \\
-20 \text { mesh } \\
1 / 18 / 91 \\
3 / 17 / 99 \\
\end{array}$ \\
\hline $\begin{array}{l}\text { PROXIMATE } \\
\% \text { moisture } \\
\% \text { ash (dry basis) }\end{array}$ & $\begin{array}{l}21.6 \\
12.6\end{array}$ & $\begin{array}{l}21.1 \\
13.0\end{array}$ & $\begin{array}{l}22.4 \\
13.1\end{array}$ & $\begin{array}{c}22.3 \\
13.3 \\
\end{array}$ & $\begin{array}{l}22.6 \\
13.2\end{array}$ \\
\hline $\begin{array}{l}\text { SULFUR FORMS (dry \%) } \\
\text { total sulfur } \\
\text { sulfate } \\
\text { pyritic } \\
\text { organic } \\
\end{array}$ & $\begin{array}{l}1.16 \\
0.02 \\
0.68 \\
0.47 \\
\end{array}$ & $\begin{array}{l}1.14 \\
0.02 \\
0.69 \\
0.43 \\
\end{array}$ & $\begin{array}{l}1.33 \\
0.02 \\
0.61 \\
0.70\end{array}$ & $\begin{array}{l}1.26 \\
0.01 \\
0.59 \\
0.67 \\
\end{array}$ & $\begin{array}{l}1.15 \\
0.01 \\
0.85 \\
0.29 \\
\end{array}$ \\
\hline $\begin{array}{l}\text { CALORIFIC VALUE (dry) } \\
\text { Btu/lb }\end{array}$ & 11536 & 11383 & 11472 & 11443 & 11524 \\
\hline $\begin{array}{l}\text { GASEOUS OXYGEN } \\
\% \text { in bag atmosphere } \\
\text { date analyzed }\end{array}$ & & & & $\begin{array}{c}0.00 \\
3 / 08 / 94\end{array}$ & $\begin{array}{c}\text { Not } \\
\text { determined }\end{array}$ \\
\hline
\end{tabular}


APPENDIX A. Monitoring of DECS Coals to Evaluate Sample Condition after Storage

\begin{tabular}{|c|c|c|c|c|c|}
\hline Beulah seam & & & $\operatorname{lig} \mathrm{A}$ & Ro ma & $x=0.35$ \\
\hline $\begin{array}{l}\text { FOIL BAG } \\
\text { particle size stored } \\
\text { note } \\
\text { date sealed } \\
\text { date analyzed }\end{array}$ & $\begin{array}{l}\text { original } \\
\text { analysis }\end{array}$ & $\begin{array}{l}27 \text { of } 256 \\
-20 \text { mesh } \\
1 / 25 / 91 \\
10 / 21 / 92\end{array}$ & $\begin{array}{r}119 \text { of } 256 \\
-20 \text { mesh } \\
1 / 25 / 91 \\
6 / 04 / 93 \\
\end{array}$ & $\begin{array}{r}94 \text { of } 256 \\
-20 \text { mesh } \\
1 / 25 / 91 \\
3 / 23 / 94\end{array}$ & $\begin{array}{l}126 \text { of } 256 \\
-20 \text { mesh } \\
1 / 25 / 91 \\
3 / 22 / 99\end{array}$ \\
\hline $\begin{array}{l}\text { PROXIMATE } \\
\% \text { moisture } \\
\% \text { ash (dry basis) } \\
\end{array}$ & $\begin{array}{r}33.4 \\
9.6 \\
\end{array}$ & $\begin{array}{l}32.5 \\
10.4 \\
\end{array}$ & $\begin{array}{r}32.9 \\
9.5 \\
\end{array}$ & $\begin{array}{r}33.1 \\
9.8 \\
\end{array}$ & $\begin{array}{r}33.8 \\
9.3 \\
\end{array}$ \\
\hline $\begin{array}{l}\text { SULFUR FORMS (dry \%) } \\
\text { total sulfur } \\
\text { sulfate } \\
\text { pyritic } \\
\text { organic } \\
\end{array}$ & $\begin{array}{l}0.74 \\
0.03 \\
0.31 \\
0.39 \\
\end{array}$ & $\begin{array}{l}0.74 \\
0.04 \\
0.24 \\
0.46 \\
\end{array}$ & $\begin{array}{l}0.74 \\
0.03 \\
0.22 \\
0.49 \\
\end{array}$ & $\begin{array}{l}0.57 \\
0.02 \\
0.25 \\
0.31 \\
\end{array}$ & $\begin{array}{l}0.80 \\
0.04 \\
0.36 \\
0.41 \\
\end{array}$ \\
\hline $\begin{array}{l}\text { CALORIFIC VALUE (dry) } \\
\text { Btu/lb }\end{array}$ & 11062 & 10863 & 11012 & 10863 & 11040 \\
\hline $\begin{array}{l}\text { GASEOUS OXYGEN } \\
\% \text { in bag atmosphere } \\
\text { date analyzed }\end{array}$ & & & & $\begin{array}{c}0.00 \\
3 / 08 / 94\end{array}$ & $\begin{array}{c}\text { Not } \\
\text { determined }\end{array}$ \\
\hline
\end{tabular}




\begin{tabular}{|c|c|c|c|c|c|c|c|c|c|c|}
\hline DECS- 12 & Pittsburgh & seam & & hvAb & & Ro $\max =$ & $=0.87 \%$ & & & \\
\hline $\begin{array}{l}\text { FOIL BAG } \\
\text { particle size stored } \\
\text { note } \\
\text { date sealed } \\
\text { date analyzed }\end{array}$ & $\begin{array}{l}\text { original } \\
\text { analysis }\end{array}$ & $\begin{array}{l}86 \text { of } 256 \\
-20 \text { mesh } \\
7 / 30 / 90 \\
7 / 31 / 91 \\
\end{array}$ & $\begin{array}{r}117 \text { of } 256 \\
-20 \text { mesh } \\
\\
7 / 30 / 90 \\
10 / 23 / 92 \\
\end{array}$ & $\begin{array}{l}120 \text { of } 256 \\
-20 \text { mesh } \\
7 / 30 / 90 \\
6 / 04 / 93 \\
\end{array}$ & $\begin{array}{r}132 \text { of } 256 \\
-20 \text { mesh } \\
\\
7 / 30 / 90 \\
3 / 23 / 94 \\
\end{array}$ & $\begin{array}{l}142 \text { of } 256 \\
-20 \text { mesh } \\
\\
7 / 30 / 90 \\
5 / 23 / 95 \\
\end{array}$ & $\begin{array}{l}155 \text { of } 256 \\
-20 \text { mesh } \\
7 / 30 / 90 \\
2 / 13 / 96 \\
\end{array}$ & $\begin{array}{l}173 \text { of } 256 \\
-20 \text { mesh } \\
7 / 30 / 90 \\
7 / 30 / 97 \\
\end{array}$ & $\begin{array}{l}62 \text { of } 256 \\
-20 \text { mesh } \\
7 / 30 / 90 \\
7 / 29 / 98 \\
\end{array}$ & $\begin{array}{l}63 \text { of } 256 \\
-20 \text { mesh } \\
7 / 30 / 90 \\
3 / 17 / 99 \\
\end{array}$ \\
\hline $\begin{array}{l}\text { PROXIMATE } \\
\% \text { moisture } \\
\% \text { ash (dry basis) }\end{array}$ & $\begin{array}{c}2.40 \\
10.25 \\
\end{array}$ & $\begin{array}{c}2.47 \\
11.05 \\
\end{array}$ & $\begin{array}{c}2.99 \\
10.35 \\
\end{array}$ & $\begin{array}{l}1.98 \\
9.52 \\
\end{array}$ & $\begin{array}{l}2.35 \\
9.86 \\
\end{array}$ & $\begin{array}{l}2.46 \\
9.69 \\
\end{array}$ & $\begin{array}{l}2.23 \\
9.34 \\
\end{array}$ & $\begin{array}{r}2.41 \\
10.12 \\
\end{array}$ & $\begin{array}{c}2.31 \\
10.8 \\
\end{array}$ & $\begin{array}{c}2.39 \\
10.6\end{array}$ \\
\hline $\begin{array}{l}\text { SULFUR FORMS (dry \%) } \\
\text { total sulfur } \\
\text { sulfate } \\
\text { pyritic } \\
\text { organic } \\
\end{array}$ & $\begin{array}{l}1.12 \\
0.01 \\
0.38 \\
0.73 \\
\end{array}$ & $\begin{array}{l}1.18 \\
0.01 \\
0.29 \\
0.88 \\
\end{array}$ & $\begin{array}{l}1.16 \\
0.01 \\
0.17 \\
0.98 \\
\end{array}$ & $\begin{array}{l}1.17 \\
0.00 \\
0.35 \\
0.82 \\
\end{array}$ & $\begin{array}{l}1.16 \\
0.00 \\
0.35 \\
0.81 \\
\end{array}$ & $\begin{array}{l}1.16 \\
0.01 \\
0.39 \\
0.76 \\
\end{array}$ & $\begin{array}{l}1.16 \\
0.01 \\
0.40 \\
0.74 \\
\end{array}$ & $\begin{array}{l}1.26 \\
0.00 \\
0.53 \\
0.73 \\
\end{array}$ & $\begin{array}{l}1.19 \\
0.01 \\
0.46 \\
0.73 \\
\end{array}$ & $\begin{array}{l}1.15 \\
0.00 \\
0.46 \\
0.68 \\
\end{array}$ \\
\hline $\begin{array}{l}\text { CALORIFIC VALUE (dry) } \\
\text { Btu/lb }\end{array}$ & 13532 & 13337 & 13471 & 13563 & 13534 & 13603 & 13646 & 13481 & 13397 & 13389 \\
\hline $\begin{array}{l}\text { GIESELER FLUIDITY } \\
\text { maximum fluidity, ddpm } \\
\text { fluid range, }{ }^{\circ} \mathrm{C} \\
\text { date analyzed } \\
\text { FREE SWELLING INDEX }\end{array}$ & $\begin{array}{c}20002 \\
90 \\
7 / 27 / 90 \\
7.5 \\
\end{array}$ & $\begin{array}{c}6458 \\
90 \\
7 / 24 / 91\end{array}$ & $\begin{array}{c}4309 \\
75 \\
10 / 27 / 92\end{array}$ & $\begin{array}{c}2173 \\
80 \\
7 / 21 / 92\end{array}$ & $\begin{array}{c}\text { (a) } \\
7866 \\
86 \\
3 / 09 / 94 \\
8 \\
\end{array}$ & $\begin{array}{c}6986 \\
83 \\
5 / 10 / 95 \\
8 \\
\end{array}$ & $\begin{array}{c}17800 \\
87 \\
1 / 24 / 96 \\
8 \\
\end{array}$ & $\begin{array}{c}20489 \\
89 \\
7 / 18 / 97 \\
9 \\
\end{array}$ & $\begin{array}{c}9152 \\
81 \\
7 / 03 / 98 \\
8.5 \\
\end{array}$ & $\begin{array}{c}\text { Not } \\
\text { determined }\end{array}$ \\
\hline $\begin{array}{l}\text { GASEOUS OXYGEN } \\
\% \text { in bag atmosphere } \\
\text { date analyzed }\end{array}$ & & & & & $\begin{array}{l}0.01 \\
3 / 08 / 94\end{array}$ & $\begin{array}{c}0.04 \\
5 / 10 / 95\end{array}$ & $\begin{array}{c}0.00 \\
1 / 18 / 96\end{array}$ & $\begin{array}{c}0.04 \\
7 / 18 / 97\end{array}$ & $\begin{aligned} & \text { (b) } \\
& 0.00 \\
& 7 / 02 / 98\end{aligned}$ & $\begin{array}{c}\text { Not } \\
\text { determined }\end{array}$ \\
\hline
\end{tabular}

(a) based on two of three runs which agreed within ASTM limits

(b) less than usual accuracy but definitely no significant oxygen 
APPENDIX A. Monitoring of DECS Coals to Evaluate Sample Condition after Storage

\begin{tabular}{|c|c|c|c|c|}
\hline Sewell seam & & $\mathrm{mvb}$ & Ro r & $a x=1.35$ \\
\hline $\begin{array}{l}\text { FOIL BAG } \\
\text { particle size stored } \\
\text { note } \\
\text { date sealed } \\
\text { date analyzed }\end{array}$ & $\begin{array}{l}\text { original } \\
\text { analysis }\end{array}$ & $\begin{array}{l}7 \text { of } 256 \\
-20 \text { mesh } \\
2 / 05 / 91 \\
12 / 07 / 92 \\
\end{array}$ & $\begin{array}{l}23 \text { of } 256 \\
-20 \text { mesh } \\
2 / 05 / 91 \\
6 / 04 / 93 \\
\end{array}$ & $\begin{array}{r}17 \text { of } 256 \\
-20 \text { mesh } \\
2 / 05 / 91 \\
3 / 25 / 94 \\
\end{array}$ \\
\hline $\begin{array}{l}\text { PROXIMATE } \\
\% \text { moisture } \\
\% \text { ash (dry basis) }\end{array}$ & $\begin{array}{l}1.5 \\
4.2 \\
\end{array}$ & $\begin{array}{l}1.8 \\
4.3 \\
\end{array}$ & $\begin{array}{l}1.5 \\
4.6 \\
\end{array}$ & $\begin{array}{l}1.8 \\
4.7 \\
\end{array}$ \\
\hline $\begin{array}{l}\text { SULFUR FORMS (dry \%) } \\
\text { total sulfur } \\
\text { sulfate } \\
\text { pyritic } \\
\text { organic } \\
\end{array}$ & $\begin{array}{l}0.62 \\
0.01 \\
0.07 \\
0.54 \\
\end{array}$ & $\begin{array}{l}0.62 \\
0.00 \\
0.07 \\
0.55 \\
\end{array}$ & $\begin{array}{l}0.65 \\
0.00 \\
0.08 \\
0.56 \\
\end{array}$ & $\begin{array}{l}0.67 \\
0.01 \\
0.09 \\
0.57 \\
\end{array}$ \\
\hline $\begin{array}{l}\text { CALORIFIC VALUE (dry) } \\
\text { Btu/lb }\end{array}$ & 14871 & 14827 & 14830 & 14884 \\
\hline $\begin{array}{l}\text { GIESELER FLUIDITY } \\
\text { maximum fluidity, ddpm } \\
\text { fluid range, }{ }^{\circ} \mathrm{C} \\
\text { date analyzed } \\
\text { FREE SWELLING INDEX } \\
\end{array}$ & $\begin{array}{r}909 \\
89 \\
2 / 18 / 91 \\
8 \\
\end{array}$ & $\begin{array}{c}1294 \\
90 \\
2 / 03 / 93\end{array}$ & $\begin{array}{r}915 \\
86 \\
7 / 23 / 93\end{array}$ & $\begin{array}{c}1676 \\
86 \\
3 / 10 / 94 \\
8.5 \\
\end{array}$ \\
\hline $\begin{array}{l}\text { GASEOUS OXYGEN } \\
\% \text { in bag atmosphere } \\
\text { date analyzed }\end{array}$ & & & & $\begin{array}{c}0.00 \\
3 / 08 / 94 \\
\end{array}$ \\
\hline
\end{tabular}




\begin{tabular}{|c|c|c|c|c|c|c|c|c|c|}
\hline \multirow[b]{2}{*}{\begin{tabular}{|l} 
DECS- 14 \\
FOIL BAG \\
particle size stored \\
note \\
date sealed \\
date analyzed
\end{tabular}} & \multicolumn{2}{|c|}{ Upper Kittanning seam } & \multicolumn{3}{|c|}{ hvAb } & & \multicolumn{3}{|c|}{ Ro $\max =1.07 \%$} \\
\hline & $\begin{array}{l}\text { original } \\
\text { analysis }\end{array}$ & $\begin{array}{l}6 \text { of } 256 \\
-20 \text { mesh } \\
2 / 08 / 91 \\
11 / 27 / 92 \\
\end{array}$ & $\begin{array}{l}20 \text { of } 256 \\
-20 \text { mesh } \\
2 / 08 / 91 \\
6 / 15 / 93 \\
\end{array}$ & $\begin{array}{l}11 \text { of } 256 \\
-20 \text { mesh } \\
2 / 08 / 91 \\
3 / 24 / 94 \\
\end{array}$ & $\begin{array}{l}16 \text { of } 256 \\
-20 \text { mesh } \\
2 / 08 / 91 \\
5 / 23 / 95 \\
\end{array}$ & $\begin{array}{l}23 \text { of } 256 \\
-20 \text { mesh } \\
2 / 08 / 91 \\
2 / 13 / 96 \\
\end{array}$ & $\begin{array}{l}24 \text { of } 256 \\
-20 \text { mesh } \\
2 / 08 / 91 \\
7 / 31 / 97 \\
\end{array}$ & $\begin{array}{l}25 \text { of } 256 \\
-20 \text { mesh } \\
2 / 08 / 91 \\
7 / 28 / 98 \\
\end{array}$ & $\begin{array}{l}26 \text { of } 256 \\
-20 \text { mesh } \\
2 / 08 / 91 \\
3 / 16 / 99 \\
\end{array}$ \\
\hline $\begin{array}{l}\text { PROXIMATE } \\
\% \text { moisture } \\
\% \text { ash (dry basis) }\end{array}$ & $\begin{array}{c}1.5 \\
10.5 \\
\end{array}$ & $\begin{array}{c}1.7 \\
10.3 \\
\end{array}$ & $\begin{array}{c}1.4 \\
10.6 \\
\end{array}$ & $\begin{array}{c}1.8 \\
10.5 \\
\end{array}$ & $\begin{array}{c}1.7 \\
10.7\end{array}$ & $\begin{array}{r}1.6 \\
10.3 \\
\end{array}$ & $\begin{array}{r}1.7 \\
10.8 \\
\end{array}$ & $\begin{array}{r}1.6 \\
10.4\end{array}$ & $\begin{array}{r}1.7 \\
10.4\end{array}$ \\
\hline $\begin{array}{l}\text { SULFUR FORMS (dry \%) } \\
\text { total sulfur } \\
\text { sulfate } \\
\text { pyritic } \\
\text { organic } \\
\end{array}$ & $\begin{array}{l}1.80 \\
0.01 \\
0.94 \\
0.85 \\
\end{array}$ & $\begin{array}{l}1.71 \\
0.01 \\
0.08 \\
1.62 \\
\end{array}$ & $\begin{array}{l}1.80 \\
0.01 \\
1.02 \\
0.78 \\
\end{array}$ & $\begin{array}{l}1.79 \\
0.01 \\
1.01 \\
0.77 \\
\end{array}$ & $\begin{array}{l}1.86 \\
0.01 \\
1.03 \\
0.82 \\
\end{array}$ & $\begin{array}{l}1.90 \\
0.01 \\
1.15 \\
0.74 \\
\end{array}$ & $\begin{array}{l}1.96 \\
0.01 \\
1.25 \\
0.71 \\
\end{array}$ & $\begin{array}{l}1.89 \\
0.00 \\
1.14 \\
0.75 \\
\end{array}$ & $\begin{array}{l}1.87 \\
0.00 \\
1.24 \\
0.63 \\
\end{array}$ \\
\hline $\begin{array}{l}\text { CALORIFIC VALUE (dry) } \\
\text { Btu/lb }\end{array}$ & 13678 & 13723 & 13701 & 13803 & 13602 & 13739 & 13621 & 13760 & 13800 \\
\hline $\begin{array}{l}\text { GIESELER FLUIDITY } \\
\text { maximum fluidity, ddpm } \\
\text { fluid range, }{ }^{\circ} \mathrm{C} \\
\text { date analyzed } \\
\text { FREE SWELLING INDEX }\end{array}$ & $\begin{array}{c}29930 \\
109 \\
2 / 19 / 91 \\
8 \\
\end{array}$ & $\begin{array}{c}27625 \\
108 \\
2 / 04 / 93\end{array}$ & $\begin{array}{c}23619 \\
104 \\
7 / 23 / 93\end{array}$ & $\begin{array}{c}29836 \\
108 \\
3 / 10 / 94 \\
7.5 \\
\end{array}$ & $\begin{array}{c}29945 \\
110 \\
5 / 16 / 95 \\
8 \\
\end{array}$ & $\begin{array}{c}29953 \\
108 \\
1 / 24 / 96 \\
7.5 \\
\end{array}$ & $\begin{array}{c}28578 \\
108 \\
7 / 23 / 97 \\
9.0 \\
\end{array}$ & $\begin{array}{c}29814 \\
110 \\
7 / 03 / 98 \\
8.5 \\
\end{array}$ & $\begin{array}{c}\text { Not } \\
\text { determined }\end{array}$ \\
\hline $\begin{array}{l}\text { GASEOUS OXYGEN } \\
\% \text { in bag atmosphere } \\
\text { date analyzed }\end{array}$ & & & & $\begin{array}{c}0.04 \\
3 / 08 / 94\end{array}$ & $\begin{array}{l}\text { (a) } \\
0 \\
5 / 15 / 95\end{array}$ & $\begin{array}{c}0.08 \\
1 / 18 / 96\end{array}$ & $\begin{array}{c}0.06 \\
7 / 22 / 97\end{array}$ & $\begin{array}{l}\text { (a) } \\
0.00 \\
7 / 02 / 98\end{array}$ & $\begin{array}{c}\text { Not } \\
\text { determined }\end{array}$ \\
\hline
\end{tabular}

(a) less than usual accuracy but definitely no significant oxygen 
APPENDIX A. Monitoring of DECS Coals to Evaluate Sample Condition after Storage

\begin{tabular}{|c|c|c|c|c|c|c|c|c|}
\hline \multirow[b]{2}{*}{$\begin{array}{l}\text { DECS-15 } \\
\text { FOIL BAG } \\
\text { particle size stored } \\
\text { note } \\
\text { date sealed } \\
\text { date analyzed }\end{array}$} & \multicolumn{2}{|c|}{ Lower Sunnyside seam } & \multicolumn{3}{|c|}{ hvAb } & \multicolumn{3}{|c|}{ Ro $\max =0.80 \%$} \\
\hline & $\begin{array}{l}\text { original } \\
\text { analysis }\end{array}$ & $\begin{array}{l}3 \text { of } 256 \\
-20 \text { mesh } \\
10 / 15 / 92 \\
11 / 27 / 92 \\
\end{array}$ & $\begin{array}{l}6 \text { of } 256 \\
-20 \text { mesh } \\
10 / 15 / 92 \\
6 / 15 / 93 \\
\end{array}$ & $\begin{array}{l}5 \text { of } 256 \\
-20 \text { mesh } \\
10 / 15 / 92 \\
3 / 24 / 94 \\
\end{array}$ & $\begin{array}{l}8 \text { of } 256 \\
-20 \text { mesh } \\
10 / 15 / 92 \\
5 / 23 / 95 \\
\end{array}$ & $\begin{array}{l}10 \text { of } 256 \\
-20 \text { mesh } \\
10 / 15 / 92 \\
2 / 13 / 96 \\
\end{array}$ & $\begin{array}{r}11 \text { of } 256 \\
-20 \text { mesh } \\
10 / 15 / 92 \\
7 / 31 / 97 \\
\end{array}$ & $\begin{array}{r}14 \text { of } 256 \\
-20 \text { mesh } \\
10 / 15 / 98 \\
7 / 28 / 98 \\
\end{array}$ \\
\hline $\begin{array}{l}\text { PROXIMATE } \\
\% \text { moisture } \\
\% \text { ash (dry basis) }\end{array}$ & $\begin{array}{c}2.9 \\
10.0 \\
\end{array}$ & $\begin{array}{c}2.9 \\
10.1 \\
\end{array}$ & $\begin{array}{l}2.6 \\
9.8\end{array}$ & $\begin{array}{l}3.1 \\
9.8\end{array}$ & $\begin{array}{c}3.0 \\
10.0 \\
\end{array}$ & $\begin{array}{c}3.0 \\
10.1 \\
\end{array}$ & $\begin{array}{r}3.2 \\
10.4 \\
\end{array}$ & $\begin{array}{c}3.0 \\
10.1 \\
\end{array}$ \\
\hline $\begin{array}{l}\text { SULFUR FORMS (dry \%) } \\
\text { total sulfur } \\
\text { sulfate } \\
\text { pyritic } \\
\text { organic } \\
\end{array}$ & $\begin{array}{l}1.65 \\
0.05 \\
0.61 \\
0.99 \\
\end{array}$ & $\begin{array}{l}1.75 \\
0.03 \\
0.94 \\
0.78 \\
\end{array}$ & $\begin{array}{l}1.62 \\
0.02 \\
0.69 \\
0.91 \\
\end{array}$ & $\begin{array}{l}1.64 \\
0.02 \\
0.76 \\
0.87 \\
\end{array}$ & $\begin{array}{l}1.66 \\
0.02 \\
0.70 \\
0.94 \\
\end{array}$ & $\begin{array}{l}1.58 \\
0.05 \\
0.77 \\
0.76 \\
\end{array}$ & $\begin{array}{c}1.65 \\
0.05 \\
0.76 \\
0.83 \\
\end{array}$ & $\begin{array}{l}1.63 \\
0.07 \\
0.77 \\
0.79 \\
\end{array}$ \\
\hline $\begin{array}{l}\text { CALORIFIC VALUE (dry) } \\
\text { Btu/lb }\end{array}$ & 13429 & 13275 & 13396 & 13553 & 13415 & 13295 & 13180 & 13334 \\
\hline $\begin{array}{l}\text { GIESELER FLUIDITY } \\
\text { maximum fluidity, ddpm } \\
\text { fluid range, }{ }^{\circ} \mathrm{C} \\
\text { date analyzed } \\
\text { FREE SWELLING INDEX }\end{array}$ & $\begin{array}{c}959 \\
76 \\
6 / 13 / 91 \\
4.5 \\
\end{array}$ & $\begin{array}{c}258 \\
75 \\
2 / 05 / 93\end{array}$ & $\begin{array}{l}170 \\
69 \\
7 / 26 / 93\end{array}$ & $\begin{array}{c}215 \\
70 \\
3 / 11 / 94 \\
4 \\
\end{array}$ & $\begin{array}{c}246 \\
72 \\
5 / 11 / 95 \\
4.5 \\
\end{array}$ & $\begin{array}{c}60 \\
63 \\
1 / 25 / 96 \\
3.5 \\
\end{array}$ & $\begin{aligned} & 68 \\
& 66 \\
& 7 / 23 / 97 \\
& 5.5 \\
&\end{aligned}$ & $\begin{array}{c}78 \\
68 \\
7 / 06 / 98 \\
5.5 \\
\end{array}$ \\
\hline $\begin{array}{l}\text { GASEOUS OXYGEN } \\
\% \text { in bag atmosphere } \\
\text { date analyzed }\end{array}$ & & & & $\begin{array}{c}0.04 \\
3 / 08 / 94\end{array}$ & $\begin{array}{c}\text { (a) } \\
0 \\
5 / 11 / 95\end{array}$ & $\begin{array}{c}0.18 \\
1 / 18 / 96 \\
\end{array}$ & $\begin{array}{c}0.01 \\
7 / 22 / 97\end{array}$ & $\begin{array}{c}(a) \\
0.00 \\
7 / 05 / 98\end{array}$ \\
\hline
\end{tabular}

(a) less than usual accuracy but definitely no significant oxygen 


\begin{tabular}{|c|c|c|c|c|c|}
\hline \multicolumn{3}{|c|}{ DECS-16 Blind Canyon seam } & \multirow{2}{*}{$\begin{array}{l}\text { hvAb } \\
36 \text { of } 256 \\
-20 \text { mesh }\end{array}$} & \multicolumn{2}{|c|}{ Ro $\max =0.64$} \\
\hline $\begin{array}{l}\text { FOIL BAG } \\
\text { particle size stored } \\
\text { note } \\
\text { date sealed } \\
\text { date analyzed }\end{array}$ & $\begin{array}{l}\text { original } \\
\text { analysis }\end{array}$ & $\begin{array}{r}7 \text { of } 256 \\
-20 \text { mesh } \\
8 / 25 / 92 \\
11 / 27 / 92 \\
\end{array}$ & & $\begin{array}{l}11 \text { of } 256 \\
-20 \text { mesh } \\
8 / 25 / 92 \\
3 / 24 / 94 \\
\end{array}$ & \\
\hline $\begin{array}{l}\text { PROXIMATE } \\
\% \text { moisture } \\
\% \text { ash (dry basis) }\end{array}$ & $\begin{array}{r}5.4 \\
13.9 \\
\end{array}$ & $\begin{array}{c}4.9 \\
15.2 \\
\end{array}$ & $\begin{array}{l}5.0 \\
15.7 \\
\end{array}$ & $\begin{array}{c}5.4 \\
15.3 \\
\end{array}$ & \\
\hline $\begin{array}{l}\text { SULFUR FORMS (dry \%) } \\
\text { total sulfur } \\
\text { sulfate } \\
\text { pyritic } \\
\text { organic } \\
\end{array}$ & $\begin{array}{l}0.47 \\
0.02 \\
0.06 \\
0.38 \\
\end{array}$ & $\begin{array}{l}0.48 \\
0.05 \\
0.07 \\
0.37 \\
\end{array}$ & $\begin{array}{l}0.46 \\
0.01 \\
0.06 \\
0.39 \\
\end{array}$ & $\begin{array}{l}0.49 \\
0.01 \\
0.06 \\
0.42 \\
\end{array}$ & \\
\hline $\begin{array}{l}\text { CALORIFIC VALUE (dry) } \\
\text { Btu//b }\end{array}$ & 12580 & 12253 & 12297 & 12418 & \\
\hline $\begin{array}{l}\text { GIESELER FLUIDITY } \\
\text { maximum fluidity, ddpm } \\
\text { fluid range, }{ }^{\circ} \mathrm{C} \\
\text { date analyzed } \\
\text { FREE SWELLING INDEX }\end{array}$ & $\begin{array}{r}6 \\
42 \\
6 / 14 / 91 \\
2 \\
\end{array}$ & $\begin{array}{c}3 \\
42 \\
2 / 08 / 93\end{array}$ & $\begin{array}{c}2 \\
41 \\
7 / 26 / 93\end{array}$ & $\begin{array}{c}2 \\
42 \\
3 / 15 / 94 \\
2 \\
\end{array}$ & \\
\hline $\begin{array}{l}\text { GASEOUS OXYGEN } \\
\% \text { in bag atmosphere } \\
\text { date analyzed }\end{array}$ & & & & $\begin{array}{c}0.02 \\
3 / 08 / 94\end{array}$ & \\
\hline
\end{tabular}


APPENDIX A. Monitoring of DECS Coals to Evaluate Sample Condition after Storage

\begin{tabular}{|c|c|c|c|c|c|c|c|c|c|}
\hline \multirow{2}{*}{$\begin{array}{l}\text { DECS-17 REFRIGER } \\
\text { FOIL BAG } \\
\text { particle size stored } \\
\text { note } \\
\text { date sealed } \\
\text { date analyzed }\end{array}$} & \multicolumn{2}{|c|}{ TED, -20 MESH } & \multicolumn{2}{|c|}{ Blind Canyon seam } & \multicolumn{2}{|c|}{ hvAb } & \multicolumn{3}{|c|}{ Ro $\max =0.59 \%$} \\
\hline & $\begin{array}{l}\text { original } \\
\text { analysis }\end{array}$ & $\begin{array}{c}204 \text { of } 256 \\
-20 \text { mesh } \\
12 / 04 / 91 \\
4 / 16 / 93 \\
\end{array}$ & $\begin{array}{c}205 \text { of } 256 \\
-20 \text { mesh } \\
12 / 04 / 91 \\
6 / 15 / 93 \\
\end{array}$ & $\begin{array}{l}17 \text { of } 256 \\
-20 \text { mesh } \\
12 / 04 / 91 \\
4 / 26 / 94 \\
\end{array}$ & $\begin{array}{c}10 \text { of } 256 \\
-20 \text { mesh } \\
12 / 04 / 91 \\
5 / 23 / 95 \\
\end{array}$ & $\begin{array}{l}11 \text { of } 256 \\
-20 \text { mesh } \\
12 / 04 / 91 \\
2 / 13 / 96 \\
\end{array}$ & $\begin{array}{l}12 \text { of } 256 \\
-20 \text { mesh } \\
12 / 04 / 91 \\
7 / 31 / 97 \\
\end{array}$ & $\begin{array}{l}13 \text { of } 256 \\
-20 \text { mesh } \\
12 / 04 / 91 \\
7 / 28 / 98 \\
\end{array}$ & $\begin{array}{r}14 \text { of } 256 \\
-20 \text { mesh } \\
12 / 04 / 91 \\
3 / 16 / 99 \\
\end{array}$ \\
\hline $\begin{array}{l}\text { PROXIMATE } \\
\% \text { moisture } \\
\% \text { ash (dry basis) }\end{array}$ & $\begin{array}{l}3.7 \\
6.6\end{array}$ & $\begin{array}{l}3.9 \\
6.6 \\
\end{array}$ & $\begin{array}{l}3.8 \\
6.7 \\
\end{array}$ & $\begin{array}{l}3.9 \\
6.4 \\
\end{array}$ & $\begin{array}{l}4.1 \\
6.5 \\
\end{array}$ & $\begin{array}{l}4.0 \\
6.7\end{array}$ & $\begin{array}{l}4.1 \\
6.7\end{array}$ & $\begin{array}{l}4.0 \\
6.4 \\
\end{array}$ & $\begin{array}{l}4.1 \\
6.6 \\
\end{array}$ \\
\hline $\begin{array}{l}\text { SULFUR FORMS (dry \%) } \\
\text { total sulfur } \\
\text { sulfate } \\
\text { pyritic } \\
\text { organic }\end{array}$ & $\begin{array}{l}0.44 \\
0.01 \\
0.02 \\
0.41\end{array}$ & $\begin{array}{l}0.43 \\
0.01 \\
0.03 \\
0.39\end{array}$ & $\begin{array}{l}0.42 \\
0.01 \\
0.05 \\
0.36\end{array}$ & $\begin{array}{l}0.47 \\
0.01 \\
0.04 \\
0.43\end{array}$ & $\begin{array}{l}0.44 \\
0.01 \\
0.04 \\
0.39\end{array}$ & $\begin{array}{l}0.43 \\
0.01 \\
0.04 \\
0.38\end{array}$ & $\begin{array}{l}0.43 \\
0.00 \\
0.06 \\
0.37\end{array}$ & $\begin{array}{l}0.44 \\
0.01 \\
0.06 \\
0.37\end{array}$ & $\begin{array}{l}0.43 \\
0.01 \\
0.07 \\
0.35\end{array}$ \\
\hline $\begin{array}{l}\text { CALORIFIC VALUE (dry) } \\
\text { Btu/lb }\end{array}$ & 13826 & 13869 & 13904 & 13926 & 13745 & 13942 & 13861 & 13872 & 13897 \\
\hline $\begin{array}{l}\text { GIESELER FLUIDITY } \\
\text { maximum fluidity, ddpm } \\
\text { fluid range, }{ }^{\circ} \mathrm{C} \\
\text { date analyzed } \\
\text { FREE SWELLING INDEX }\end{array}$ & $\begin{array}{c}5 \\
55 \\
8 / 16 / 91 \\
2 \\
\end{array}$ & $\begin{array}{c}4 \\
52 \\
10 / 28 / 92\end{array}$ & $\begin{array}{l}2 \\
47 \\
7 / 27 / 93\end{array}$ & $\begin{array}{c}2 \\
44 \\
4 / 20 / 94 \\
2 \\
\end{array}$ & $\begin{array}{c}2 \\
48 \\
5 / 16 / 95 \\
2.5 \\
\end{array}$ & $\begin{array}{c}2 \\
46 \\
1 / 26 / 96 \\
1.5 \\
\end{array}$ & $\begin{array}{c}3 \\
48 \\
7 / 24 / 97 \\
2 \\
\end{array}$ & $\begin{array}{c}3 \\
43 \\
7 / 07 / 98 \\
4.5 \\
\end{array}$ & $\begin{array}{c}\text { Not } \\
\text { determined }\end{array}$ \\
\hline $\begin{array}{l}\text { GASEOUS OXYGEN } \\
\% \text { in bag atmosphere } \\
\text { date analyzed }\end{array}$ & & & & $\begin{array}{c}0.00 \\
4 / 20 / 94\end{array}$ & $\begin{array}{l}\text { (a) } \\
0 \\
5 / 16 / 95\end{array}$ & $\begin{array}{c}0.10 \\
1 / 18 / 96\end{array}$ & $\begin{array}{c}0.00 \\
7 / 22 / 97\end{array}$ & $\begin{array}{c}\text { (a) } \\
0.00 \\
7 / 06 / 98\end{array}$ & $\begin{array}{c}\text { Not } \\
\text { determined }\end{array}$ \\
\hline
\end{tabular}

(a) less than usual accuracy but definitely no significant oxygen 


\begin{tabular}{|c|c|c|c|c|c|c|c|}
\hline DECS-18 & Kentucky \#9 seam & $\mathrm{hvBb}$ & Ro $m$ & $=0.56$ & & & \\
\hline $\begin{array}{l}\text { FOIL BAG } \\
\text { particle size stored } \\
\text { note } \\
\text { date sealed } \\
\text { date analyzed }\end{array}$ & $\begin{array}{l}\text { original } \\
\text { analysis }\end{array}$ & $\begin{array}{c}3 \text { of } 256 \\
-20 \text { mesh } \\
10 / 09 / 92 \\
6 / 18 / 93\end{array}$ & $\begin{array}{l}2 \text { of } 256 \\
-20 \text { mesh } \\
10 / 09 / 92 \\
4 / 26 / 94\end{array}$ & $\begin{array}{c}5 \text { of } 256 \\
-20 \text { mesh } \\
10 / 09 / 92 \\
5 / 25 / 95\end{array}$ & $\begin{array}{l}8 \text { of } 256 \\
-20 \text { mesh } \\
10 / 09 / 92 \\
2 / 13 / 96\end{array}$ & $\begin{array}{l}15 \text { of } 256 \\
-20 \text { mesh } \\
\\
10 / 09 / 92 \\
7 / 28 / 98\end{array}$ & $\begin{array}{r}20 \text { of } 256 \\
-20 \text { mesh } \\
10 / 09 / 92 \\
3 / 16 / 99\end{array}$ \\
\hline $\begin{array}{l}\text { PROXIMATE } \\
\% \text { moisture } \\
\% \text { ash (dry basis) }\end{array}$ & $\begin{array}{r}6.8 \\
12.3 \\
\end{array}$ & $\begin{array}{r}7.3 \\
11.3 \\
\end{array}$ & $\begin{array}{l}7.4 \\
11.8 \\
\end{array}$ & $\begin{array}{c}7.4 \\
11.7\end{array}$ & $\begin{array}{r}7.1 \\
11.7\end{array}$ & $\begin{array}{r}7.5 \\
12.2\end{array}$ & $\begin{array}{r}7.7 \\
11.9\end{array}$ \\
\hline $\begin{array}{l}\text { SULFUR FORMS (dry \%) } \\
\text { total sulfur } \\
\text { sulfate } \\
\text { pyritic } \\
\text { organic } \\
\end{array}$ & $\begin{array}{l}4.21 \\
0.01 \\
2.37 \\
1.83 \\
\end{array}$ & $\begin{array}{l}3.91 \\
0.04 \\
1.78 \\
2.10 \\
\end{array}$ & $\begin{array}{l}3.97 \\
0.04 \\
1.99 \\
1.94 \\
\end{array}$ & $\begin{array}{l}4.02 \\
0.03 \\
1.71 \\
2.27 \\
\end{array}$ & $\begin{array}{l}4.05 \\
0.01 \\
2.03 \\
2.01 \\
\end{array}$ & $\begin{array}{l}4.16 \\
0.13 \\
1.91 \\
2.13 \\
\end{array}$ & $\begin{array}{l}3.76 \\
0.21 \\
2.02 \\
1.54 \\
\end{array}$ \\
\hline $\begin{array}{l}\text { CALORIFIC VALUE (dry) } \\
\text { Btu/lb }\end{array}$ & 12687 & 12763 & 12794 & 12723 & 12818 & 12688 & 12615 \\
\hline $\begin{array}{l}\text { GIESELER FLUIDITY } \\
\text { maximum fluidity, ddpm } \\
\text { fluid range, }{ }^{\circ} \mathrm{C} \\
\text { date analyzed } \\
\text { FREE SWELLING INDEX }\end{array}$ & $\begin{array}{c}527 \\
80 \\
2 / 11 / 93 \\
2 \\
\end{array}$ & $\begin{array}{c}409 \\
74 \\
7 / 29 / 93\end{array}$ & $\begin{array}{c}159 \\
73 \\
4 / 11 / 94 \\
3 \\
\end{array}$ & $\begin{array}{c}677 \\
90 \\
5 / 12 / 95 \\
4 \\
\end{array}$ & $\begin{array}{c}513 \\
82 \\
1 / 25 / 96 \\
3.5 \\
\end{array}$ & $\begin{array}{c}421 \\
70 \\
7 / 07 / 98 \\
6 \\
\end{array}$ & $\begin{array}{c}\text { Not } \\
\text { determined }\end{array}$ \\
\hline $\begin{array}{l}\text { GASEOUS OXYGEN } \\
\% \text { in bag atmosphere } \\
\text { date analyzed }\end{array}$ & & & $\begin{array}{c}0.21 \\
3 / 29 / 94\end{array}$ & $\begin{array}{c}\text { (a) } \\
0 \\
5 / 12 / 95\end{array}$ & $\begin{array}{c}0.09 \\
1 / 18 / 96\end{array}$ & $\begin{array}{l}\text { (a) } \\
0.00 \\
7 / 06 / 98\end{array}$ & $\begin{array}{c}\text { Not } \\
\text { determined }\end{array}$ \\
\hline
\end{tabular}

(a) less than usual accuracy but definitely no significant oxygen 
APPENDIX A. Monitoring of DECS Coals to Evaluate Sample Condition after Storage

\begin{tabular}{|c|c|c|c|c|}
\hline \multirow[b]{2}{*}{$\begin{array}{l}\text { DECS-19 Pocaho } \\
\text { FOIL BAG } \\
\text { particle size stored } \\
\text { note } \\
\text { date sealed } \\
\text { date analyzed } \\
\end{array}$} & \multirow[b]{2}{*}{$\begin{array}{l}\text { seam } \\
\begin{array}{l}\text { original } \\
\text { analysis }\end{array} \\
8 / 21 / 92\end{array}$} & \multirow[b]{2}{*}{$\begin{array}{c}\text { Ivb } \\
10 \text { of } 256 \\
-20 \text { mesh } \\
7 / 14 / 92 \\
6 / 18 / 93 \\
\end{array}$} & \multicolumn{2}{|c|}{ Ro $\max =1.71$} \\
\hline & & & $\begin{array}{l}9 \text { of } 256 \\
-20 \text { mesh } \\
7 / 14 / 92 \\
4 / 26 / 94\end{array}$ & $\begin{array}{l}27 \text { of } 256 \\
-20 \text { mesh } \\
7 / 14 / 92 \\
3 / 16 / 99\end{array}$ \\
\hline $\begin{array}{l}\text { PROXIMATE } \\
\% \text { moisture } \\
\% \text { ash (dry basis) } \\
\end{array}$ & $\begin{array}{l}1.0 \\
4.6 \\
\end{array}$ & $\begin{array}{l}0.8 \\
5.5\end{array}$ & $\begin{array}{l}0.8 \\
5.4\end{array}$ & $\begin{array}{l}0.9 \\
5.5 \\
\end{array}$ \\
\hline $\begin{array}{l}\text { SULFUR FORMS (dry \%) } \\
\text { total sulfur } \\
\text { sulfate } \\
\text { pyritic } \\
\text { organic } \\
\end{array}$ & $\begin{array}{l}0.74 \\
0.00 \\
0.21 \\
0.52 \\
\end{array}$ & $\begin{array}{l}0.78 \\
0.00 \\
0.24 \\
0.53 \\
\end{array}$ & $\begin{array}{l}0.77 \\
0.01 \\
0.26 \\
0.50 \\
\end{array}$ & $\begin{array}{l}0.76 \\
0.00 \\
0.33 \\
0.42 \\
\end{array}$ \\
\hline $\begin{array}{l}\text { CALORIFIC VALUE (dry) } \\
\text { Btu/lb }\end{array}$ & 15006 & 14790 & 14867 & 14854 \\
\hline $\begin{array}{l}\text { GIESELER FLUIDITY } \\
\text { maximum fluidity, ddpm } \\
\text { fluid range, }{ }^{\circ} \mathrm{C} \\
\text { date analyzed } \\
\text { FREE SWELLING INDEX } \\
\end{array}$ & $\begin{array}{c}17 \\
50 \\
1 / 22 / 93 \\
6 \\
\end{array}$ & $\begin{array}{c}9 \\
52 \\
7 / 30 / 93\end{array}$ & $\begin{array}{c}13 \\
53 \\
4 / 18 / 94 \\
7.5 \\
\end{array}$ & $\begin{array}{c}\text { Not } \\
\text { determined }\end{array}$ \\
\hline $\begin{array}{l}\text { GASEOUS OXYGEN } \\
\% \text { in bag atmosphere } \\
\text { date analyzed }\end{array}$ & & & $\begin{array}{c}0.08 \\
4 / 18 / 94 \\
\end{array}$ & $\begin{array}{c}\text { Not } \\
\text { determined }\end{array}$ \\
\hline
\end{tabular}




\begin{tabular}{|c|c|c|c|}
\hline Elkhorn \#3 seam & hvAb & & $\max =0.87$ \\
\hline $\begin{array}{l}\text { FOIL BAG } \\
\text { particle size stored } \\
\text { note } \\
\text { date sealed } \\
\text { date analyzed }\end{array}$ & $\begin{array}{l}\text { original } \\
\text { analysis }\end{array}$ & $\begin{array}{l}16 \text { of } 256 \\
-20 \text { mesh } \\
7 / 15 / 92 \\
6 / 18 / 93 \\
\end{array}$ & $\begin{array}{l}5 \text { of } 256 \\
-20 \text { mesh } \\
7 / 15 / 92 \\
4 / 26 / 94 \\
\end{array}$ \\
\hline $\begin{array}{l}\text { PROXIMATE } \\
\% \text { moisture } \\
\% \text { ash (dry basis) }\end{array}$ & $\begin{array}{l}2.8 \\
5.5 \\
\end{array}$ & $\begin{array}{l}2.7 \\
5.2 \\
\end{array}$ & $\begin{array}{l}2.8 \\
5.1\end{array}$ \\
\hline $\begin{array}{l}\text { SULFUR FORMS (dry \%) } \\
\text { total sulfur } \\
\text { sulfate } \\
\text { pyritic } \\
\text { organic } \\
\end{array}$ & $\begin{array}{l}0.97 \\
0.00 \\
0.21 \\
0.75 \\
\end{array}$ & $\begin{array}{l}0.96 \\
0.00 \\
0.17 \\
0.78 \\
\end{array}$ & $\begin{array}{l}1.01 \\
0.02 \\
0.21 \\
0.78 \\
\end{array}$ \\
\hline $\begin{array}{l}\text { CALORIFIC VALUE (dry) } \\
\text { Btu/lb }\end{array}$ & 14244 & 14204 & 14277 \\
\hline $\begin{array}{l}\text { GIESELER FLUIDITY } \\
\text { maximum fluidity, ddpm } \\
\text { fluid range, }{ }^{\circ} \mathrm{C} \\
\text { date analyzed } \\
\text { FREE SWELLING INDEX } \\
\end{array}$ & $\begin{array}{c}1612 \\
66 \\
1 / 19 / 93 \\
4 \\
\end{array}$ & $\begin{array}{c}1149 \\
66 \\
7 / 30 / 93\end{array}$ & $\begin{array}{r}1206 \\
69 \\
4 / 18 / 94 \\
4 \\
\end{array}$ \\
\hline $\begin{array}{l}\text { GASEOUS OXYGEN } \\
\% \text { in bag atmosphere } \\
\text { date analyzed }\end{array}$ & & & $\begin{array}{r}0.00 \\
4 / 18 / 94 \\
\end{array}$ \\
\hline
\end{tabular}


APPENDIX A. Monitoring of DECS Coals to Evaluate Sample Condition after Storage

\begin{tabular}{||l|l|c|c||}
\hline \hline DECS-21 Lykens Valley \#2 seam & \multicolumn{3}{c||}{ Ro max= 5.19 } \\
\hline FOIL BAG & $\begin{array}{l}\text { original } \\
\text { analysis }\end{array}$ & 6 of 256 & 25 of 256 \\
particle size stored & & -20 mesh & -20 mesh \\
note & & & \\
date sealed & $5 / 03 / 93$ & $4 / 26 / 94$ & $3 / 16 / 99$ \\
date analyzed & & & \\
\hline PROXIMATE & 4.0 & 4.2 & 4.0 \\
\% moisture & 10.7 & 11.5 & 10.9 \\
\% ash (dry basis) & & & \\
\hline SULFUR FORMS (dry \%) & 0.50 & 0.51 & 0.47 \\
total sulfur & 0.00 & 0.01 & 0.01 \\
sulfate & 0.60 & 0.08 & 0.12 \\
pyritic & 0.43 & 0.42 & 0.34 \\
Organic & & & \\
\hline CALORIFIC VALUE (dry) & 13284 & 13336 & 13356 \\
Btu/lb & & & \\
\hline GASEOUS OXYGEN & & 0.03 & Not \\
\% in bag atmosphere & & $4 / 19 / 94$ & determined \\
\hline date analyzed & & &
\end{tabular}




\begin{tabular}{||l|c|c||}
\hline \multicolumn{2}{||c|}{ DECS-22 Upper Kittanning seam } & \multicolumn{2}{c||}{ hvAb } & Ro max=0.77 \\
\hline FOIL BAG & $\begin{array}{l}\text { original } \\
\text { analysis }\end{array}$ & 3 of 256 \\
particle size stored & & -20 mesh \\
note & & \\
date sealed & & $6 / 18 / 93$ \\
date analyzed & $6 / 25 / 93$ & $4 / 22 / 94$ \\
\hline PROXIMATE & & \\
$\%$ moisture & 0.9 & 0.9 \\
$\%$ ash (dry basis) & 23.1 & 22.8 \\
\hline SULFUR FORMS (dry \%) & & \\
total sulfur & 1.71 & 1.61 \\
sulfate & 0.03 & 0.03 \\
pyritic & 1.15 & 1.12 \\
organic & 0.53 & 0.47 \\
\hline CALORIFIC VALUE (dry) & & \\
Btu/lb & 11786 & 11837 \\
\hline GIESELER FLUIDITY & & \\
maximum fluidity, ddpm & 11719 & 8991 \\
fluid range, ${ }^{\circ} \mathrm{C}$ & 66 & 60 \\
date analyzed & $6 / 23 / 93$ & $4 / 20 / 94$ \\
FREE SWELLING INDEX & 1 & 1 \\
\hline GASEOUS OXYGEN & & 0.04 \\
\% in bag atmosphere & & $4 / 19 / 94$ \\
date analyzed & & \\
\hline
\end{tabular}




\section{APPENDIX A. Monitoring of DECS Coals to Evaluate Sample Condition after Storage}

\begin{tabular}{|c|c|c|c|c|c|}
\hline \multirow[b]{2}{*}{$\begin{array}{l}\text { DECS-23 } \\
\text { FOIL BAG } \\
\text { particle size stored } \\
\text { note } \\
\text { date sealed } \\
\text { date analyzed }\end{array}$} & Pittsburgh seam & \multicolumn{2}{|c|}{ hvAb } & \multicolumn{2}{|c|}{ Ro $\max =0.73 \%$} \\
\hline & $\begin{array}{l}\text { original } \\
\text { analysis }\end{array}$ & $\begin{array}{l}17 \text { of } 256 \\
-20 \text { mesh } \\
2 / 11 / 94 \\
2 / 08 / 95\end{array}$ & $\begin{array}{l}18 \text { of } 256 \\
-20 \text { mesh } \\
2 / 11 / 94 \\
11 / 30 / 95\end{array}$ & $\begin{array}{l}19 \text { of } 256 \\
-20 \text { mesh } \\
2 / 11 / 94 \\
7 / 30 / 97 \\
\end{array}$ & $\begin{array}{l}16 \text { of } 256 \\
-20 \text { mesh } \\
2 / 11 / 94 \\
7 / 28 / 98\end{array}$ \\
\hline $\begin{array}{l}\text { PROXIMATE } \\
\% \text { moisture } \\
\% \text { ash (dry basis) }\end{array}$ & $\begin{array}{l}2.00 \\
9.44 \\
\end{array}$ & $\begin{array}{l}2.03 \\
9.64 \\
\end{array}$ & $\begin{array}{l}2.09 \\
9.67 \\
\end{array}$ & $\begin{array}{l}2.13 \\
9.61 \\
\end{array}$ & $\begin{array}{l}2.12 \\
9.60 \\
\end{array}$ \\
\hline $\begin{array}{l}\text { SULFUR FORMS (dry \%) } \\
\text { total sulfur } \\
\text { sulfate } \\
\text { pyritic } \\
\text { organic } \\
\end{array}$ & $\begin{array}{l}3.87 \\
0.01 \\
2.23 \\
1.63 \\
\end{array}$ & $\begin{array}{l}3.79 \\
0.01 \\
2.42 \\
1.36 \\
\end{array}$ & $\begin{array}{l}3.66 \\
0.00 \\
2.45 \\
1.20 \\
\end{array}$ & $\begin{array}{l}3.89 \\
0.00 \\
2.73 \\
1.16 \\
\end{array}$ & $\begin{array}{l}4.09 \\
0.01 \\
2.72 \\
1.36 \\
\end{array}$ \\
\hline $\begin{array}{l}\text { CALORIFIC VALUE (dry) } \\
\text { Btu/lb }\end{array}$ & 13614 & 13553 & 13565 & 13487 & 13628 \\
\hline $\begin{array}{l}\text { GIESELER FLUIDITY } \\
\text { maximum fluidity, ddpm } \\
\text { fluid range, }{ }^{\circ} \mathrm{C} \\
\text { date analyzed } \\
\text { FREE SWELLING INDEX }\end{array}$ & $\begin{array}{c}30000 \\
97 \\
2 / 07 / 94 \\
7.5 \\
\end{array}$ & $\begin{array}{l}30000 \\
106 \\
1 / 23 / 95 \\
7 \\
\end{array}$ & $\begin{array}{c}30000 \\
100 \\
11 / 28 / 95 \\
7.5 \\
\end{array}$ & $\begin{array}{l}30002 \\
104 \\
7 / 15 / 97 \\
9 \\
\end{array}$ & $\begin{array}{c}30000 \\
101 \\
7 / 09 / 98 \\
7 \\
\end{array}$ \\
\hline $\begin{array}{l}\text { GASEOUS OXYGEN } \\
\% \text { in bag atmosphere } \\
\text { date analyzed }\end{array}$ & & $\begin{array}{c}\text { (a) } \\
0 \\
5 / 16 / 95 \\
\end{array}$ & $\begin{array}{l}\text { not } \\
\text { determined }\end{array}$ & $\begin{array}{c}0.00 \\
7 / 15 / 97 \\
\end{array}$ & $\begin{array}{c}(a) \\
0.00 \\
7 / 06 / 98 \\
\end{array}$ \\
\hline
\end{tabular}

(a) less than usual accuracy but definitely no significant oxygen 


\begin{tabular}{|c|c|c|c|c|c|}
\hline Illinois \#6 & am & hvBb & & $\mathrm{ax}=0.49 \%$ & \\
\hline $\begin{array}{l}\text { FOIL BAG } \\
\text { particle size stored } \\
\text { note } \\
\text { date sealed } \\
\text { date analyzed }\end{array}$ & $\begin{array}{l}\text { original } \\
\text { analysis }\end{array}$ & $\begin{array}{l}105 \text { of } 328 \\
-20 \text { mesh } \\
7 / 19 / 94 \\
2 / 08 / 95 \\
\end{array}$ & $\begin{array}{c}106 \text { of } 328 \\
-20 \text { mesh } \\
7 / 19 / 94 \\
11 / 29 / 95 \\
\end{array}$ & $\begin{array}{l}107 \text { of } 328 \\
-20 \text { mesh } \\
7 / 19 / 94 \\
7 / 30 / 97 \\
\end{array}$ & $\begin{array}{l}133 \text { of } 328 \\
-20 \text { mesh } \\
7 / 19 / 94 \\
7 / 28 / 98 \\
\end{array}$ \\
\hline $\begin{array}{l}\text { PROXIMATE } \\
\% \text { moisture } \\
\% \text { ash (dry basis) }\end{array}$ & $\begin{array}{l}13.2 \\
13.4 \\
\end{array}$ & $\begin{array}{l}13.4 \\
13.5 \\
\end{array}$ & $\begin{array}{l}13.4 \\
13.6 \\
\end{array}$ & $\begin{array}{l}13.4 \\
13.5 \\
\end{array}$ & $\begin{array}{l}13.4 \\
13.4 \\
\end{array}$ \\
\hline $\begin{array}{l}\text { SULFUR FORMS (dry \%) } \\
\text { total sulfur } \\
\text { sulfate } \\
\text { pyritic } \\
\text { organic } \\
\end{array}$ & $\begin{array}{l}5.53 \\
0.25 \\
2.64 \\
2.64 \\
\end{array}$ & $\begin{array}{l}5.92 \\
0.01 \\
2.86 \\
3.05 \\
\end{array}$ & $\begin{array}{l}5.76 \\
0.01 \\
2.77 \\
2.98 \\
\end{array}$ & $\begin{array}{l}5.75 \\
0.06 \\
2.96 \\
2.73 \\
\end{array}$ & $\begin{array}{l}5.87 \\
0.01 \\
2.99 \\
2.88 \\
\end{array}$ \\
\hline $\begin{array}{l}\text { CALORIFIC VALUE (dry) } \\
\text { Btu/lb }\end{array}$ & 12162 & 12074 & 12242 & 12203 & 12300 \\
\hline $\begin{array}{l}\text { GIESELER FLUIDITY } \\
\text { maximum fluidity, ddpm } \\
\text { fluid range, }{ }^{\circ} \mathrm{C} \\
\text { date analyzed } \\
\text { FREE SWELLING INDEX }\end{array}$ & $\begin{array}{c}49 \\
78 \\
6 / 14 / 94 \\
3 \\
\end{array}$ & $\begin{array}{c}55 \\
82 \\
1 / 24 / 95 \\
3.5 \\
\end{array}$ & $\begin{array}{c}53 \\
82 \\
11 / 29 / 95 \\
3.5 \\
\end{array}$ & $\begin{array}{c}54 \\
74 \\
7 / 16 / 97 \\
6 \\
\end{array}$ & $\begin{array}{c}56 \\
76 \\
7 / 09 / 98 \\
5.5 \\
\end{array}$ \\
\hline $\begin{array}{l}\text { GASEOUS OXYGEN } \\
\% \text { in bag atmosphere } \\
\text { date analyzed }\end{array}$ & & $\begin{array}{c}\text { (a) } \\
0 \\
5 / 16 / 95\end{array}$ & $\begin{array}{l}\text { not } \\
\text { determined }\end{array}$ & $\begin{array}{c}0.00 \\
7 / 15 / 97\end{array}$ & $\begin{array}{c}\text { (a) } \\
0.00 \\
7 / 06 / 98\end{array}$ \\
\hline
\end{tabular}

(a) less than usual accuracy but definitely no significant oxygen 


\section{APPENDIX A. Monitoring of DECS Coals to Evaluate Sample Condition after Storage}

\begin{tabular}{||l|c|c||}
\hline DECS-25 Pust seam & \multicolumn{2}{c|}{ ligA $2.23 \%$} \\
\hline FOIL BAG & $\begin{array}{l}\text { original } \\
\text { analysis }\end{array}$ & 62 of 280 \\
particle size stored & & -20 mesh \\
note & & \\
date sealed & $9 / 07 / 94$ & $3 / 17 / 94$ \\
date analyzed & & \\
\hline PROXIMATE & 34.9 & 35.9 \\
$\%$ moisture & 11.9 & 11.0 \\
\% ash (dry basis) & & \\
\hline SULFUR FORMS (dry \%) & 0.72 & 0.80 \\
total sulfur & 0.05 & 0.03 \\
sulfate & 0.31 & 0.47 \\
pyritic & 0.35 & 0.29 \\
Organic & & \\
\hline CALORIFIC VALUE (dry) & 10947 & 10938 \\
Btu/lb & & \\
\hline GASEOUS OXYGEN & Not & \\
\% in bag atmosphere & determined & \\
date analyzed & \multicolumn{2}{|l}{} \\
\hline
\end{tabular}




\begin{tabular}{|c|c|c|c|}
\hline Upper Banner No. 3 & seam & hvAb & $\mathrm{ax}=1.00 \%$ \\
\hline $\begin{array}{l}\text { FOIL BAG } \\
\text { particle size stored } \\
\text { note } \\
\text { date sealed } \\
\text { date analyzed }\end{array}$ & $\begin{array}{l}\text { original } \\
\text { analysis }\end{array}$ & $\begin{array}{l}37 \text { of } 328 \\
-20 \text { mesh } \\
7 / 10 / 95 \\
7 / 28 / 98\end{array}$ & $\begin{array}{l}35 \text { of } 328 \\
-20 \text { mesh } \\
7 / 10 / 95 \\
3 / 17 / 99\end{array}$ \\
\hline $\begin{array}{l}\text { PROXIMATE } \\
\% \text { moisture } \\
\% \text { ash (dry basis) } \\
\end{array}$ & $\begin{array}{l}2.4 \\
6.4 \\
\end{array}$ & $\begin{array}{l}2.3 \\
6.4 \\
\end{array}$ & $\begin{array}{l}2.3 \\
6.5 \\
\end{array}$ \\
\hline $\begin{array}{l}\text { SULFUR FORMS (dry \%) } \\
\text { total sulfur } \\
\text { sulfate } \\
\text { pyritic } \\
\text { organic } \\
\end{array}$ & $\begin{array}{l}0.59 \\
0.01 \\
0.09 \\
0.50 \\
\end{array}$ & $\begin{array}{l}0.59 \\
0.01 \\
0.17 \\
0.41 \\
\end{array}$ & $\begin{array}{l}0.56 \\
0.01 \\
0.20 \\
0.35 \\
\end{array}$ \\
\hline $\begin{array}{l}\text { CALORIFIC VALUE (dry) } \\
\text { Btu/lb }\end{array}$ & 14543 & 14521 & 14492 \\
\hline $\begin{array}{l}\text { GIESELER FLUIDITY } \\
\text { maximum fluidity, ddpm } \\
\text { fluid range, }{ }^{\circ} \mathrm{C} \\
\text { date analyzed } \\
\text { FREE SWELLING INDEX } \\
\end{array}$ & $\begin{array}{l}8942 \\
90 \\
6 / 29 / 95 \\
8 \\
\end{array}$ & $\begin{array}{c}10538 \\
84 \\
7 / 10 / 98 \\
8.5 \\
\end{array}$ & $\begin{array}{c}\text { Not } \\
\text { determined }\end{array}$ \\
\hline $\begin{array}{l}\text { GASEOUS OXYGEN } \\
\% \text { in bag atmosphere } \\
\text { date analyzed }\end{array}$ & & $\begin{array}{l}\text { (a) } \\
0.00 \\
7 / 06 / 98\end{array}$ & $\begin{array}{c}\text { Not } \\
\text { determined }\end{array}$ \\
\hline
\end{tabular}

(a) less than usual accuracy but definitely no significant oxygen 


\section{APPENDIX A. Monitoring of DECS Coals to Evaluate Sample Condition after Storage}

\begin{tabular}{|c|c|c|c|}
\hline Splash Dam seam & $\mathrm{mvb}$ & Ro $\max =$ & $1.16 \%$ \\
\hline $\begin{array}{l}\text { FOIL BAG } \\
\text { particle size stored } \\
\text { note } \\
\text { date sealed } \\
\text { date analyzed }\end{array}$ & $\begin{array}{l}\text { original } \\
\text { analysis }\end{array}$ & $\begin{array}{l}35 \text { of } 280 \\
-20 \text { mesh } \\
7 / 11 / 95 \\
8 / 01 / 97 \\
\end{array}$ & $\begin{array}{l}37 \text { of } 280 \\
-20 \text { mesh } \\
7 / 11 / 95 \\
3 / 17 / 99 \\
\end{array}$ \\
\hline $\begin{array}{l}\text { PROXIMATE } \\
\% \text { moisture } \\
\% \text { ash (dry basis) }\end{array}$ & $\begin{array}{l}2.06 \\
3.89\end{array}$ & $\begin{array}{l}1.59 \\
3.99\end{array}$ & $\begin{array}{l}1.53 \\
4.01\end{array}$ \\
\hline $\begin{array}{l}\text { SULFUR FORMS (dry \%) } \\
\text { total sulfur } \\
\text { sulfate } \\
\text { pyritic } \\
\text { organic } \\
\end{array}$ & $\begin{array}{l}0.79 \\
0.00 \\
0.14 \\
0.65 \\
\end{array}$ & $\begin{array}{l}0.80 \\
0.00 \\
0.20 \\
0.60 \\
\end{array}$ & $\begin{array}{l}0.78 \\
0.01 \\
0.25 \\
0.53 \\
\end{array}$ \\
\hline $\begin{array}{l}\text { CALORIFIC VALUE (dry) } \\
\text { Btu/lb }\end{array}$ & 15060 & 14967 & 15018 \\
\hline $\begin{array}{l}\text { GIESELER FLUIDITY } \\
\text { maximum fluidity, ddpm } \\
\text { fluid range, }{ }^{\circ} \mathrm{C} \\
\text { date analyzed } \\
\text { FREE SWELLING INDEX }\end{array}$ & $\begin{array}{c}28188 \\
117 \\
6 / 30 / 95 \\
8 \\
\end{array}$ & $\begin{array}{c}19182 \\
110 \\
7 / 31 / 97 \\
9 \\
\end{array}$ & $\begin{array}{c}\text { Not } \\
\text { determined }\end{array}$ \\
\hline $\begin{array}{l}\text { GASEOUS OXYGEN } \\
\% \text { in bag atmosphere } \\
\text { date analyzed }\end{array}$ & & $\begin{array}{c}0.00 \\
7 / 25 / 97\end{array}$ & $\begin{array}{c}\text { Not } \\
\text { determined }\end{array}$ \\
\hline
\end{tabular}


APPENDIX A. Monitoring of DECS Coals to Evaluate Sample Condition after Storage

\begin{tabular}{|c|c|c|c|}
\hline Pond Creek seam & hvAb & Ro max & $.99 \%$ \\
\hline $\begin{array}{l}\text { FOIL BAG } \\
\text { particle size stored } \\
\text { note } \\
\text { date sealed } \\
\text { date analyzed }\end{array}$ & $\begin{array}{l}\text { original } \\
\text { analysis }\end{array}$ & $\begin{array}{l}35 \text { of } 280 \\
-20 \text { mesh } \\
7 / 12 / 95 \\
8 / 01 / 97 \\
\end{array}$ & \\
\hline $\begin{array}{l}\text { PROXIMATE } \\
\% \text { moisture } \\
\% \text { ash (dry basis) } \\
\end{array}$ & $\begin{array}{r}2.32 \\
10.89 \\
\end{array}$ & $\begin{array}{c}1.94 \\
11.46 \\
\end{array}$ & \\
\hline $\begin{array}{l}\text { SULFUR FORMS (dry \%) } \\
\text { total sulfur } \\
\text { sulfate } \\
\text { pyritic } \\
\text { organic } \\
\end{array}$ & $\begin{array}{l}0.60 \\
0.01 \\
0.11 \\
0.49 \\
\end{array}$ & $\begin{array}{l}0.63 \\
0.01 \\
0.17 \\
0.46 \\
\end{array}$ & \\
\hline $\begin{array}{l}\text { CALORIFIC VALUE (dry) } \\
\text { Btu/lb }\end{array}$ & 13689 & 13467 & \\
\hline $\begin{array}{l}\text { GIESELER FLUIDITY } \\
\text { maximum fluidity, ddpm } \\
\text { fluid range, }{ }^{\circ} \mathrm{C} \\
\text { date analyzed } \\
\text { FREE SWELLING INDEX } \\
\end{array}$ & $\begin{array}{l}3634 \\
79 \\
6 / 28 / 95 \\
8 \\
\end{array}$ & $\begin{array}{c}3472 \\
74 \\
7 / 28 / 97 \\
9 \\
\end{array}$ & \\
\hline $\begin{array}{l}\text { GASEOUS OXYGEN } \\
\% \text { in bag atmosphere } \\
\text { date analyzed }\end{array}$ & & $\begin{array}{c}0.00 \\
7 / 28 / 97\end{array}$ & \\
\hline
\end{tabular}




\section{APPENDIX A. Monitoring of DECS Coals to Evaluate Sample Condition after Storage}

\begin{tabular}{|c|c|c|c|}
\hline Stockton-Le & Stockton-Lewiston seam & \multicolumn{2}{|c|}{ Ro $\max =1.16 \%$} \\
\hline $\begin{array}{l}\text { FOIL BAG } \\
\text { particle size stored } \\
\text { note } \\
\text { date sealed } \\
\text { date analyzed }\end{array}$ & $\begin{array}{l}\text { original } \\
\text { analysis }\end{array}$ & $\begin{array}{l}35 \text { of } 280 \\
-20 \text { mesh } \\
7 / 13 / 95 \\
8 / 01 / 95 \\
\end{array}$ & \\
\hline $\begin{array}{l}\text { PROXIMATE } \\
\% \text { moisture } \\
\% \text { ash (dry basis) }\end{array}$ & $\begin{array}{r}2.64 \\
20.30 \\
\end{array}$ & $\begin{array}{r}2.42 \\
20.88 \\
\end{array}$ & \\
\hline $\begin{array}{l}\text { SULFUR FORMS (dry \%) } \\
\text { total sulfur } \\
\text { sulfate } \\
\text { pyritic } \\
\text { organic } \\
\end{array}$ & $\begin{array}{l}0.73 \\
0.01 \\
0.10 \\
0.62 \\
\end{array}$ & $\begin{array}{l}0.73 \\
0.00 \\
0.17 \\
0.55 \\
\end{array}$ & \\
\hline $\begin{array}{l}\text { CALORIFIC VALUE (dry) } \\
\text { Btu/lb }\end{array}$ & 11853 & 11685 & \\
\hline $\begin{array}{l}\text { GIESELER FLUIDITY } \\
\text { maximum fluidity, ddpm } \\
\text { fluid range, }{ }^{\circ} \mathrm{C} \\
\text { date analyzed } \\
\text { FREE SWELLING INDEX }\end{array}$ & $\begin{array}{c}450 \\
67 \\
6 / 27 / 95 \\
5 \\
\end{array}$ & $\begin{array}{c}472 \\
64 \\
7 / 29 / 97 \\
5.5 \\
\end{array}$ & \\
\hline $\begin{array}{l}\text { GASEOUS OXYGEN } \\
\% \text { in bag atmosphere } \\
\text { date analyzed }\end{array}$ & & $\begin{array}{c}0.00 \\
7 / 28 / 97\end{array}$ & \\
\hline
\end{tabular}




\begin{tabular}{|c|c|c|c|}
\hline Ohio \#4A seam & $\mathrm{hvBb}$ & \multicolumn{2}{|c|}{ Ro $\max =0.51 \%$} \\
\hline $\begin{array}{l}\text { FOIL BAG } \\
\text { particle size stored } \\
\text { note } \\
\text { date sealed } \\
\text { date analyzed }\end{array}$ & $\begin{array}{l}\text { original } \\
\text { analysis }\end{array}$ & $\begin{array}{l}35 \text { of } 280 \\
-20 \text { mesh } \\
8 / 02 / 95 \\
8 / 01 / 97 \\
\end{array}$ & $\begin{array}{l}57 \text { of } 280 \\
-20 \text { mesh } \\
8 / 02 / 95 \\
3 / 17 / 99 \\
\end{array}$ \\
\hline $\begin{array}{l}\text { PROXIMATE } \\
\% \text { moisture } \\
\% \text { ash (dry basis) }\end{array}$ & $\begin{array}{l}5.97 \\
12.0 \\
\end{array}$ & $\begin{array}{l}5.86 \\
12.0 \\
\end{array}$ & $\begin{array}{l}5.95 \\
12.0 \\
\end{array}$ \\
\hline $\begin{array}{l}\text { SULFUR FORMS (dry \%) } \\
\text { total sulfur } \\
\text { sulfate } \\
\text { pyritic } \\
\text { organic } \\
\end{array}$ & $\begin{array}{l}3.74 \\
0.01 \\
1.41 \\
2.32 \\
\end{array}$ & $\begin{array}{l}3.76 \\
0.01 \\
1.84 \\
1.92 \\
\end{array}$ & $\begin{array}{l}4.18 \\
0.10 \\
1.81 \\
2.27 \\
\end{array}$ \\
\hline $\begin{array}{l}\text { CALORIFIC VALUE (dry) } \\
\text { Btu/lb }\end{array}$ & 12617 & 12662 & 12569 \\
\hline $\begin{array}{l}\text { GIESELER FLUIDITY } \\
\text { maximum fluidity, ddpm } \\
\text { fluid range, }{ }^{\circ} \mathrm{C} \\
\text { date analyzed } \\
\text { FREE SWELLING INDEX }\end{array}$ & $\begin{array}{l}86 \\
75 \\
7 / 28 / 95 \\
4 \\
\end{array}$ & $\begin{array}{c}116 \\
66 \\
7 / 30 / 97 \\
5 \\
\end{array}$ & $\begin{array}{c}\text { Not } \\
\text { determined }\end{array}$ \\
\hline $\begin{array}{l}\text { GASEOUS OXYGEN } \\
\% \text { in bag atmosphere } \\
\text { date analyzed }\end{array}$ & & $\begin{array}{c}0.00 \\
7 / 28 / 97\end{array}$ & $\begin{array}{c}\text { Not } \\
\text { determined }\end{array}$ \\
\hline
\end{tabular}




\section{APPENDIX B. Procedures for Standardized Liquefaction Test of DECS Samples including Extraction and Gas Analysis}

\section{MATERIALS}

Solvents (HPLC grade)

Tetrahydrofuran (THF)

Hexane

Toluene

1-methylnaphthalene $98 \%$

1,2,3,4-tetrahydronaphthalene $99 \%$ (tetralin)

\section{Equipment}

Buchi RE111 Rotovapor

Omega XA-100 balance

Napco \#5831 vacuum oven

sand bath reactor

stir plate

$\underline{\text { Reactor Vessels }}$

4 tubing bomb reactors with 2000 psi pressure gauges and Swagelok fittings

$$
\text { approximately } 24 \mathrm{ml} \text { capacity }
$$

$\underline{\text { Glassware and other supplies }}$

(NOTE: all glassware is baked at $450^{\circ} \mathrm{C}$ prior to use; all other supplies are rinsed with THF)

$250 \mathrm{ml}$ beakers

$250 \mathrm{ml}$ round bottom flasks

$400 \mathrm{ml}$ round bottom flasks

Soxhlet apparatus (for extractions)

Whatman glass microfibre filters (GF/C)

Whatman glass microfibre extraction thimbles (GF; 30x100mm)

boiling chips (cleaned with THF)

compressed nitrogen

gas-tight syringe

gas bulbs

metal spatula

magnetic stirrer

Petri dish 


\section{LIQUEFACTION}

For each complete standardized liquefaction analysis, perform the following procedure for two tubing-bomb reactors using tetralin and two tubing-bomb reactors using 1-methylnaphthalene.

Ensure that baking of glassware and rinsing of other supplies has been performed.

All items which come in contact with sample or resulting products must be weighed to $0.0001 \mathrm{~g}$ before and after contact so that sample loss may be calculated.

Weigh out 5 grams of freeze-dried coal and 5 grams of tetralin (or 1-methylnaphthalene) and place both into the tubing bomb reactor.

Screw the end caps of the reactor on very tightly.

Fill and then purge the reactor with nitrogen up to 1000 psi (repeat 3 times).

Fill the reactor with hydrogen up to 1000 psi and then purge very slowly (over a period of $5 \mathrm{~min}$.). Repeat 3 times. After the third fill, close the valve on the reactor, leaving it pressurized with hydrogen.

Submerge the reactor in water to check for leaks.

Place the reactor in a secure place where it is in a stable position. Observe the pressure reading on the gauge. If the pressure remains stable for 10 minutes you may assume no significant leaks exist.

Place the reactor into the sand bath which has been set at $350^{\circ} \mathrm{C}$. The temperature of the sand bath will decrease rapidly after introducing the reactor. Wait until the temperature reaches $350^{\circ} \mathrm{C}$ and then begin timing the length of the run (30 minutes).

After 30 min remove the reactor from the sand bath and submerge it in water to cool the reactor.

At this point remember to keep the valve on the reactor closed and to store it in a secure place if it must be stored temporarily.

\section{GAS ANALYSIS}

Measuring the volume of gas

Attach a Swagelok purge valve with a $15 \mathrm{~cm}$ length of tubing onto the reactor, making sure that the valve on the reactor remains closed. 
Onto the other end of the tubing, attach a flow-through gas bulb.

Onto the other end of the gas bulb attach a 1-meter length of tubing, so that the sequence is: reactor, Swagelok purge valve, tubing, gas bulb (for trapping gas), and a longer piece of tubing (1 meter).

Place the end of the longer piece of tubing into an inverted graduated cylinder filled with water. (For these reactions, gas production has been from 1-2 liters, so a 2 liter graduated cylinder is suggested.)

Make sure that the valves on the flow-through gas bulb are open.

Slowly open the valve on the reactor. Water should begin to evacuate from the inverted graduated cylinder as the gas displaces it.

When all the gas has left the reactor, close both valves on the flow-through gas bulb (trapping a sample of gas in the bulb).

Close the valve on the reactor.

From the inverted graduated cylinder, read the volume of gas that was in the reactor and record the data.

Take a gas-tight syringe and sample $1 \mathrm{ml}$ of the gas from the bulb. Inject the sample into the gas chromatograph.

The gas chromatograph is then run to analyze for $\mathrm{CO}_{2}$ and $\mathrm{C} 1, \mathrm{C} 2, \mathrm{C} 3$ and $\mathrm{C} 4$ compounds.

After injection of the gaseous sample and the completion of the run, an external gaseous standard must be injected for a separate run (this will allow for the quantification of the sample injection).

\section{$\underline{\text { Soxhlet extraction }}$}

Open the reactor.

Rinse the contents of the reactor into an extraction thimble (place the thimble in a $250 \mathrm{ml}$ beaker) using no more than $200 \mathrm{ml}$ of toluene. The products will be adhered to the sides of the reactor and in the caps; scraping with the metal spatula will be necessary. Be careful not to spill any sample; this is where the greatest chance for error lies.

Take a 250ml round bottom flask, add boiling chips, and then attach to the Soxhlet apparatus. 
Place the extraction thimble into the Soxhlet and then pour the contents of the beaker into the thimble. With more toluene, rinse the beaker into the thimble. Make sure that all of the sample is in the thimble and not lying in the bottom of the Soxhlet.

After all of the sample has been washed into the extraction thimble, add enough toluene to the round bottom flask to bring the total amount of toluene up to approximately $200 \mathrm{ml}$ (this includes the amount of toluene that is also in the Soxhlet). Soxhlet.

Using tubing, connect the tank of compressed nitrogen to the condensing tower on the

Turn on the nitrogen to the point where there is a light flow of gas going through the Soxhlet.

Turn on the water to the condensing tower.

Turn on the heating mantle and bring the toluene in the $250 \mathrm{ml}$ flask to a moderate boil.

At this point the toluene should start to cycle through the Soxhlet extractor.

Continue the extraction until the toluene in the Soxhlet has become colorless again. This takes approximately $48 \mathrm{~h}$.

During this time it may be necessary to add more toluene to maintain a volume of $200 \mathrm{ml}$.

After the extraction is complete, turn off the mantle and allow the solution to cool to room temperature.

Keeping the round bottom flask attached to the Soxhlet, tilt the assembly until the toluene in the Soxhlet pours into the $250 \mathrm{ml}$ round bottom flask.

After this is done, separate the $250 \mathrm{ml}$ round bottom flask from the Soxhlet and set the $250 \mathrm{ml}$ round bottom flask aside temporarily (these instructions resume below).

Take another $250 \mathrm{ml}$ round bottom flask, containing boiling chips, and fill it with approximately $200 \mathrm{ml}$ of THF.

Attach the $250 \mathrm{ml}$ round bottom flask to the Soxhlet.

Turn on the heating mantle and bring the THF to a moderate boil. The THF should start to cycle through the Soxhlet (remember, both the water and nitrogen should still be on).

This extraction should also take approximately $48 \mathrm{~h}$. However, continue until the THF in the Soxhlet has become colorless again. 
After the THF extraction is under way, return to the $250 \mathrm{ml}$ round bottom flask containing the toluene and toluene extractable material.

Transfer the contents of the $250 \mathrm{ml}$ round bottom flask into a $400 \mathrm{ml}$ round bottom flask. Be sure to rinse the $250 \mathrm{ml}$ round bottom flask (using toluene) into the $400 \mathrm{ml}$ round bottom flask at least 3 times.

Rotovaporate the $400 \mathrm{ml}$ round bottom flask, which will remove most of the toluene. (However, there will be some left, as well as some liquid product from the extraction).

After rotary evaporation, add approximately $400 \mathrm{ml}$ of hexane to the $400 \mathrm{ml}$ round bottom flask.

Add a magnetic stirrer to the $400 \mathrm{ml}$ round bottom flask.

Stir the contents of the $400 \mathrm{ml}$ round bottom flask for exactly $1 \mathrm{~h}$.

After stirring, cover the $400 \mathrm{ml}$ round bottom flask and let it sit overnight.

The next day, filter the contents of the $400 \mathrm{ml}$ round bottom flask through the Whatman $\mathrm{GF} / \mathrm{C}$ glass microfibre filters. Be sure to rinse the contents of the $400 \mathrm{ml}$ round bottom flask into the filter using hexane; rinse at least 3 times.

Transfer the filter paper, boiling chips, magnetic stirrer, and hexane- insoluble matter into a Petri dish (you may wish to rinse off the stirrer and remove it from the Petri dish before placing the dish in the vacuum drying oven).

Rotovaporate the hexane solubles (the solution not caught in the filter) to remove hexane. (This will remove most of the hexane; however, there will be some hexane as well as some liquid product from the extraction left in the round bottom flask).

Place both the Petri dish and the round bottom flask into the vacuum drying oven at $150^{\circ}$ $\mathrm{C}$ for $2 \mathrm{~h}$.

After drying, weigh the samples. The sample in the Petri dish is the asphaltene fraction. The sample in the round bottom flask is the oil fraction.

Return to the THF extraction:

Once the THF in the Soxhlet is colorless turn off the mantle and let cool to room temperature.

After cooling, turn off the nitrogen and the water. 
Keeping the round bottom flask attached to the Soxhlet, tilt the assembly until the THF in the Soxhlet pours into the $250 \mathrm{ml}$ round bottom flask.

Wash all of the contents of the $250 \mathrm{ml}$ round bottom flask into a $400 \mathrm{ml}$ round bottom flask using THF.

Rinse the $250 \mathrm{ml}$ round bottom flask into the $400 \mathrm{ml}$ round bottom flask using THF at least 3 times.

Rotovaporate the $400 \mathrm{ml}$ round bottom flask (this will remove most of the THF; however, some THF and a liquid product from the extraction will be left.

Place the $400 \mathrm{ml}$ round bottom flask in the vacuum drying oven at $150^{\circ} \mathrm{C}$ for $2 \mathrm{~h}$.

After drying, weigh the product in the $400 \mathrm{ml}$ round bottom flask. This is the preasphaltene fraction.

Remove the extraction thimble from the Soxhlet and place in the vacuum drying oven.

After drying, weigh the product in the thimble. This is the insoluble fraction.

\section{Calculation of Product Distribution and Conversion}

Apply the calculated sample weight losses from the before-contact and after-contact weighing of glassware and supplies to the appropriate steps in conversion calculation procedures.

insoluble residue weight $=$ (wt. of thimble + wt. of sample remaining in thimble after all extractions are completed) - wt. of thimble (clean)

preasphaltenes weight $=w t$. of $250 \mathrm{ml}$ round bottom flask (containing boiling chips and dried extract) - (wt of $250 \mathrm{ml}$ round bottom flask (clean) $+\mathrm{wt}$. of boiling chips (clean))

$\underline{\text { asphaltenes weight }}=$ wt. of Petri dish (containing boiling chips, dried extract, filter paper, and stirrer) - (wt. of petri dish (clean) + wt. of boiling chips (clean) + wt. of filter paper (clean) + wt. of stirrer (clean))

oil fraction weight $=$ wt. of $500 \mathrm{ml}$ flat bottom flask (containing dried extract) - wt. of $500 \mathrm{ml}$ flat bottom flask (clean)

gas fraction (recovered using $\mathrm{GC})$ weight $=$ wt. of $\left(\mathrm{CO}_{2}+\mathrm{C} 1+\mathrm{C} 2+\mathrm{C} 3+\mathrm{C} 4\right)$ 
weight of total recovered material $=$ (wt. of insoluble residue + wt. of preasphaltenes + wt. of asphaltenes + wt. of oil fraction + wt. of gas fraction)

Conversion $\%$ for specific fraction $=$ wt. of fraction $\times 100 \% /$ wt. of original sample (before liquefaction)

$\underline{\text { Conversion \% (total) }}=$ (wt. of preasphaltenes + wt. of asphaltenes + wt. of oil fraction + wt. of gas fraction) x $100 \%$ / wt. of original sample (before liquefaction)

The procedures used were presented in the Quarterly Technical Progress Report for January through March, 1994. The calculations listed therein were on a raw (ash-containing) basis, and the gas fraction and total recovered material weights were incorrect; correct explanations for values on an ash-free basis (which will be used henceforth) are as follows:

gas fraction weight by difference $=$ initial sample weight - (weights of insoluble residue + preasphaltenes + asphaltenes + oil fraction)

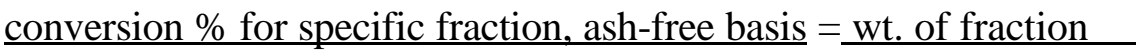
initial weight $*(1-(\operatorname{ash} \% / 100 \%))$

$\underline{\text { conversion } \% \text { (total, ash-free basis) }}=$ initial weight - insoluble residue weight initial weight $*(1-(\operatorname{ash} \% / 100 \%))$ 


\section{APPENDIX C. Agencies Supplied with Coal Samples and/or Data 9/29/93 to 3/30/99}

The numbers in parentheses represent multiple requests which were separately processed.

ABB Combustion Engineering

Action Mining, Inc.

Advanced Fuel Research (3)

American Colloid Company (3)

Amoco

APTI Geoscience Operations

ARCO Oil and Gas Company

Arctech, Inc. (3)

Argonne National Laboratory (2)

Arizona State University, Chemistry Department

Auburn University, Chemical Engineering Department (3)

Babcock and Wilcox, Alliance Research Center

Battelle Memorial Institute

Bell Laboratories

Brigham Young University, Chemical Engineering Department (2)

Brown University, Division of Engineering (5)

Buckeye Industrial Mining Company (4)

Burgueno, Mrs. M.

Cal Tech University

Calcott Consulting (Australia)

Calgon Carbon (2)

Carbon Sales, Inc. (3)

Centenary College, Chemistry Department

Central Research Institute for Electric Power, Biosciences Department, Japan

Centre Lime \& Stone Company

Chevron Petroleum Technology Company (2)

City College of New York, Chemical Engineering Department

Clark Atlanta University, Chemistry Department (3)

Coal Education Development and Resources (CEDAR) Program of Eastern Kentucky

Coal Technology Corporation (6)

Colorado School of Mines

Colorado Geological Survey

Colorado State University, Natural Resource Ecology Laboratory

Columbia University, Geology Department

Cominco, Inc. (Canada)

Consol Pennsylvania Coal Company

CSIRO Division of Energy Technology (Australia) (2)

E.I. Dupont de Nemours and Company, Central Research and Development

East Fairfield Coal Company

Eco-Systems 


\section{EER}

Emission Monitoring, Inc.

Exergetic Systems (2)

Exportech, Inc.

Exxon Production Research Company (5)

Exxon Research and Engineering Center

Foster-Wheeler Development Corp. (3)

Geological Survey of Denmark

Geological Survey of Canada

GeoMet, Inc.

Giant Foods

Global Import/ Export of Charleston (2)

Goldman-Sachs

Hazen Research

Hokkaido University, Faculty of Engineering (Japan) (2)

Illinois State Geological Survey (5)

Imperial College, Chemical Engineering Department (United Kingdom)

Indiana Geological Survey (3)

Instituto Nacional del Carbon (Spain)

Internal Revenue Service (3)

International Committee on Coal and Organic Petrology

KAIST, Department of Chemical Engineering (S. Korea) (3)

Kelastic, Inc. (2)

Kentucky Geological Survey

Keystone Filler Co.

Lamar University, Chemical Engineering Department

Larsen, Mr. David

Law Environmental

Levine, Jeffrey R., Consulting Geologist

Little Bear Laboratories, Montana (3)

Marshall University, Chemistry Department

Michigan Tech University, Metals and Materials Engineering Research

Mineral Labs, Inc.

Monash University, Chemistry Department (Australia) (4)

National Institutes of Occupational Safety and Health (4)

National Mining Association (2)

National Institute of Standards and Technology

New York University Medical Center, Nelson Institute of Environmental Medicine (2)

Nittany Geosciences, Inc.

North Carolina A \& T State University, Mechanical Engineering Department (2)

Northeastern University, Mechanical Engineering Department (6)

Oak Ridge National Laboratory (2)

Oklahoma Geological Survey

Original Fuels Co. (2) 
Pennsylvania Bureau of Mining and Reclamation

Pennsylvania Department of Environmental Protection

Pennsylvania Department of Environmental Resources, Hawk Run Field Office

Pennsylvania Geological Survey

Pennsylvania Power and Light Company

Pennsylvania State University, Chemical Engineering Department (2)

Pennsylvania State University, Coal and Organic Petrology Laboratories (3)

Pennsylvania State University, Energy and Fuels Research Center (10)

Pennsylvania State University, Energy and Geo-Environmental Engineering Dept. (4)

Pennsylvania State University, The Energy Institute (12)

Pennsylvania State University, Fuel Science Program (78)

Pennsylvania State University, Geosciences Department (15)

Pennsylvania State University, Materials Research Laboratory

Pennsylvania State University, Mineral Processing Program (14)

Pennsylvania State University, Mining Engineering Program (5)

Pennsylvania State University, Office of Physical Plant, Steam Plant

Pennsylvania State University, Polymer Science Program (13)

Pickands-Mather Coal Company (2)

PSI Technology Co.

Ralph Gray Services

Reaction Engineering

Rice University, Chemistry Department

Rocky Mountain Institute (3)

RTC Consultants

Rust College, Division of Science and Mathematics (2)

Salem Tool, Inc.

Sandia National Laboratory (3)

Seoul National University, Civil, Urban \& Geosystem Engineering Department (S. Korea)

SGI International, Development Center

Shell Exploration and Production Technology Company (6)

Shell (5)

Silogran Trading Ltd. (Switzerland)

Southern Illinois University, Geology Department (5)

Southern Illinois University, Mining Engineering Department

Southern Illinois University, Mechanical Engineering Department

Southern Illinois University

SRI International (3)

SRI International, Molecular Physics Department

Stanford University, Geosciences Department

Tata, Inc.

TDA Research

Technical University of Denmark, Lab. of Heating and Air Conditioning (Denmark)

Technology Management Associates International

TIMCAL (Switzerland) (2) 
Tri-Valley Research Company (2)

Truman, Mr. James

Tuskegee Institute

U.S. Geological Survey (13)

U.S. Department of Energy, Federal Energy Technology Center (4)

U.S. Department of Energy, Pittsburgh Energy Technology Center (5)

U.S. Environmental Protection Agency

U.S. Office of Surface Mining

Universidade do Porto (Portugal) (2)

Università degli studi di Napoli Federico II, Chemical Engineering Department (Italy)

Université Pierre et Marie Curie, Lab. Géochemie et Métallogénie (France)

University of Alabama at Birmingham, Geology Department (2)

University of British Columbia, Earth and Ocean Sciences Department (Canada)

University of British Columbia, Pathology Department (Canada)

University of California at Davis, Chemical Eng. \& Materials Science Dept.

University of Cincinnati, Chemical Engineering Department (2)

University of Cincinnati, Civil and Environmental Engineering Department (8)

University of Cincinnati, Engineering Research Division (2)

University of Delaware, Chemical Engineering Department (15)

University of Kentucky, Center for Applied Energy Research

University of Kentucky, Consortium for Fossil Fuel Liquefaction Science (2)

University of Maryland

University of Maryland of the Eastern Shore, Natural Sciences Department

University of Mississippi

University of Mississippi, Chemical Engineering Department (3)

University of Newcastle, Chemical Engineering Department (Australia) (2)

University of North Dakota, Energy and Environmental Research Center

University of Oklahoma

University of Oklahoma, Chemical Engineering and Materials Science Department

University of Oklahoma, School of Geology and Geophysics (2)

University of Pittsburgh, Chemical Engineering Department (3)

University of South Carolina, Biology Department (2)

University of Southern California, Chemical Engineering Department

University of Tennessee, Geology Department (2)

University of Tennessee at Knoxville, Geological Science Department

University of Texas of the Permian Basin, Chemistry Faculty (2)

University of Utah (2)

University of Utah, Center for Microanalysis (2)

University of Utah, Chemical and Fuels Engineering Department (2)

University of Utah, Chemistry Department (6)

University of Wyoming, Department of Chemical and Petroleum Engineering (2)

Unocal Science and Technology Division (4)

Utah Geological Survey (3)

Viking Systems 
Virginia Division of Mineral Resources (2)

Washington and Jefferson College, Chemistry Department

West Virginia University, Chemical Engineering Department (10)

West Virginia University, Geology Department (2)

West Virginia University, Physics Department (2)

Western Research Institute

WPSX Television

Wyoming State Geological Survey 
APPENDIX D. Coal Database Printouts of DECS Samples 
The Penn State Coal Sample Bank and Database

Sample DECS-23

page 1 of 4

Pittsburgh Seam

huAb rank

printed $8 / 24 / 95$

Washington County, PA

\section{SAMPLE LOCATION}

Washington County, Pennsylvania, USA

West Finley Township near West Finley, Pennsylvania

Eastern Coal Province

Appalachian Region

Main Bituminous

Wind Ridge ( $\left.7.5^{\prime}\right)$ Topographic Quadrangle

Latitude $39^{\circ} 58^{\prime} 48^{\prime \prime}$ North, Longitude $80^{\circ} 27^{\prime} 36^{\prime \prime}$ West

\section{SAMPLE HISTORY}

Whole-Seam Channel Sample collected February 2, 1994 by Penn State

Mining method: underground

4" rider \& 4" parting above main seam not sampled

Coal Sample Bank reserve: $202 \mathrm{~kg}$ (446 1bs)

\section{SAMPLE INFORMATION}

Pennsylvanian

Monongahela Group

Seam thickness at sample location: $216 \mathrm{~cm}$ (7 ft 1 in.)

Sample thickness:

$216 \mathrm{~cm}(7 \mathrm{ft} 1 \mathrm{in.})$

Seam profile:

ROOF
$20 \mathrm{~cm}$
$5 \mathrm{~cm}$
$46 \mathrm{~cm}$
$51 \mathrm{~cm}$
$8 \mathrm{~cm}$
$86 \mathrm{~cm}$
FLOOR

gray mudstone

bright clarain, shale lenses

parting not sampled

clarain with shale, pyrite

clarain; 1" high vitrain layer

clarain; partings not sampled

clarain with vitrain, shale

gray mudstone 
The Penn State Coal Sample Bank and Database

Pittsburgh Seam

Washington County, PA
hvAb rank
Sample DECS-23

page 2 of 4

printed $8 / 24 / 95$

sampled $2 / 02 / 94$

\section{- PROXIMATE ANALYSIS}

\begin{tabular}{|c|c|c|c|c|}
\hline & as rec'd & dry & daf & $\operatorname{dmmf}(P a r r)$ \\
\hline$\%$ Ash & 9.25 & 9.44 & & \\
\hline $\begin{array}{l}\% \text { Vol. Matter } \\
\% \text { Fixed Carbon }\end{array}$ & $\begin{array}{l}38.63 \\
50.12\end{array}$ & $\begin{array}{l}39.42 \\
51.14\end{array}$ & $\begin{array}{l}43.53 \\
56.47\end{array}$ & $\begin{array}{l}42.33 \\
57.67\end{array}$ \\
\hline
\end{tabular}

\section{- SULFUR FORMS}

$\begin{array}{lll} & \text { dry } & \frac{\text { daf }}{2.46} \\ \% \text { Pyritic } & 2.23 & 0.01 \\ \% \text { Sulfate } & 0.01 & 1.80 \\ \% \text { Organic } & 1.63 & 4.27 \\ \% \text { Total } & 3.87 & 4\end{array}$

\section{MOISTURE}

$\%$ as received

2.00

$\%$ equilibrium

2.50

\section{ULTIMATE ANALYSIS}

$\%$ Ash

$\%$ Carbon

$\%$ Hydrogen

$\%$ Nitrogen

\% Total Sulfur

$\%$ Oxygen (diff.)

$$
\begin{aligned}
& \text { as } \frac{r^{2} c^{\prime} d}{9.25} \quad \frac{\text { dry }}{9.44} \\
& 72.72 \quad 74.21 \\
& 5.00^{*} \quad 5.10 \\
& 1.32 \quad 1.35 \\
& 3.79 \quad 3.87 \\
& 5.91 * \quad 6.03 \\
& 4.27 \\
& \text { daf } \frac{d m m f(P a r r)}{(12.32 \% M M)} \\
& 81.95 \quad 84.64 \\
& 5.63 \quad 5.82 \\
& 1.49 \quad 1.54 \\
& 6.66 \\
& 8.00
\end{aligned}
$$

Dry \% Chlorine $=0.10 \quad$ Dry \% Carbon dioxide $=0.12$

\section{ELEMENTAL ANALYSIS}

\% Carbon

\% Hydrogen

\begin{tabular}{|c|c|c|c|c|c|c|}
\hline \multirow{3}{*}{$\begin{array}{l}\text { MM-containing } \\
\text { MM-free (Parr) } \\
\text { MM-free (mod. Parr) } \\
\text { Net, dmmf Btu/lb }\end{array}$} & \multicolumn{2}{|c|}{ dry } & \multicolumn{2}{|c|}{ as rec'd moist } & \multicolumn{2}{|c|}{ equil. moist } \\
\hline & $\begin{array}{l}\frac{M \mathrm{~J} / \mathrm{kg}}{31.664} \\
35.602 \\
35.569 \\
34.322\end{array}$ & $\begin{array}{l}\text { Btu/Tb } \\
13614 \\
15307 \\
15293 \\
14757\end{array}$ & $\begin{array}{l}\overline{\mathrm{MJ} / \mathrm{kg}} \\
31.031 \\
34.792 \\
34.764\end{array}$ & $\begin{array}{l}\text { Btu/1b } \\
13342 \\
14959 \\
14947\end{array}$ & $\begin{array}{l}\mathrm{MJ} / \mathrm{kg} \\
30.873 \\
34.590 \\
34.564\end{array}$ & $\begin{array}{r}\text { Btu/1b } \\
13274 \\
14872 \\
14861\end{array}$ \\
\hline & & & & dif & $=26 \mathrm{E}$ & $/ 1 \mathrm{~b}$ \\
\hline
\end{tabular}

$\%$ Nitrogen

\% Organic Sulfur

$\%$ Oxygen (diff.)

$\%$ Mineral Matter

(incl. $4.17 \% \mathrm{FeS}_{2}$ ) dry $\quad \frac{d m m f(M o d . P)}{(11.77 \% ~ M M)}$

$\begin{array}{ll}74.18 & 84.07\end{array}$

$\begin{array}{rr}5.02 & 5.69\end{array}$

$1.35 \quad 1.53$

$1.63 \quad 1.85$

$\begin{array}{ll}6.06 & 6.86\end{array}$
$1.77 \% \mathrm{MM})$

\section{CALORIFIC VALUE (Gross)}

\section{ATOMIC RATIOS (dmmf)}

Atomic $\mathrm{H} / \mathrm{C}$

Parr mod. Parr

Atomic $0 / C$

$\overline{0.825}$

0.813

0.061 
The Penn State Coal Sample Bank and Database

Sample DECS-23

Pittsburgh Seam

Washington County, PA

hvAb rank

page 3 of 4

printed $8 / 24 / 95$

sampled 2/02/94

\section{RANK CALCULATIONS}

ASTM Rank (equilibrium moist.) hvAb Reflectance Rank hvAb

$$
\text { (as rec'd moist.) hvab }
$$

\section{MACERAL COMPOSITION (blue + white light, volume \%)}

Vitrinite

TOTAL VITRINITE

Fusinite

Semifusinite

Macrinite

Micrinite

Sclerotinite

Inertodetrinite

TOTAL INERTINITE

$$
\frac{\begin{array}{c}
\text { mineral- } \\
\text { free }
\end{array}}{79.4} \quad \frac{\begin{array}{c}
\text { mineral- } \\
\text { containing }
\end{array}}{79.4}-\frac{74.3}{74.3}
$$

$\begin{array}{ll}1.7 & 1.6\end{array}$

$8.5 \quad 8.0$

$0.0 \quad 0.0$

$\begin{array}{ll}3.0 & 2.8\end{array}$

$0.0 \quad 0.0$

$0.5 \quad 0.5$

$\begin{array}{ll}13.7 & 12.9\end{array}$

Sporinite

$5.2 \quad 4.9$

Resinite

0.2

0.2

0.0

0.0

0.6

0.6

0.9

0.8

Liptodetrinite

Exudatinite

Bituminite

Fluorinite

TOTAL LIPTINITE

6.9

6.5

Mineral matter (Parr, volume \%)

6.34

\section{REFLECTANCE DATA}

Vitrinite: Mean-max $R_{0}: 0.73 \%$

$\begin{array}{lllll}\text { Vtypes: } & V 5 & \frac{V 6}{20} & \frac{V 7}{73.0} & \frac{V 8}{6.0}\end{array}$

\section{CAKING AND MECHANICAL PROPERTIES}

Free-swelling index

7.5

Hardgrove grindability index

Vickers' microhardness index

56.8

Washability data not available

n.d.

Gieseler Coal Plastometer:

Initial softening $\quad 373^{\circ} \mathrm{C}$

Maximum fluidity $\quad 428^{\circ} \mathrm{C}$

Solidification

$470^{\circ} \mathrm{C}$

Fluid temp. range

$97^{\circ} \mathrm{C}$

Maximum fluidity

$30000 \mathrm{ddpm}$ 
The Penn State Coal Sample Bank and Database

Pittsburgh Seam

hvAb rank

Sample DECS-23

page 4 of 4

Washington County, PA

printed $8 / 24 / 95$

sampled 2/02/94

\section{INORGANIC ELEMENT ANALYSIS}

\begin{tabular}{|c|c|c|c|}
\hline \multicolumn{3}{|c|}{ Major Elements } & \\
\hline & oxide \% & & of whole \\
\hline & $\frac{\text { of HTA }}{36.3}$ & & $\frac{\operatorname{dry} \operatorname{coa} l}{1.6}$ \\
\hline $\mathrm{Al}_{2} \mathrm{O}_{3}$ & 17.6 & A1 & 0.9 \\
\hline $\mathrm{TiO}_{2}$ & 0.76 & $\mathrm{Ti}$ & 0.04 \\
\hline $\mathrm{Fe}_{2} \mathrm{O}_{3}$ & 36.7 & $\mathrm{Fe}$ & 2.4 \\
\hline $\mathrm{MgO}^{\circ}$ & 0.62 & $\mathrm{Mg}$ & 0.04 \\
\hline $\mathrm{CaO}$ & 3.03 & $\mathrm{Ca}$ & 0.20 \\
\hline $\mathrm{Na}_{2} \mathrm{O}$ & 0.33 & $\mathrm{Na}$ & 0.02 \\
\hline $\mathrm{K}_{2} \mathrm{O}$ & 1.41 & K & 0.11 \\
\hline $\mathrm{P}_{2}^{2} \mathrm{O}_{5}$ & 0.59 & P & 0.024 \\
\hline & 1.70 & & \\
\hline
\end{tabular}

High-temperature ash (HTA) used for inorganic analysis $=9.39 \%$ of whole dry coal

Trace Elements ppm ppm whole dry HTA coal

$\mathrm{Ag}$

As

$\mathrm{Ba}$

$\mathrm{Be}$

$B i$

$\mathrm{Cd}$

$\mathrm{Ce}$

CI

Co

$\mathrm{Cr}$

$\mathrm{Cu}$

Ga

$\mathrm{Ge}$

$\mathrm{Hg}$

La

$\mathrm{Mn}$

$\mathrm{Nb}$

$\mathrm{Ni}$

$\mathrm{Pb}$

$\mathrm{Rb}$

So

Se

Sn

Sr

Th

U

V

$Y$

$Y b$

$\mathrm{Zn}$ $<0.2$

537

11

13

51

1

$<0.2$

1000

115

110

11

10

0.12

310

29

85

32

8

6

3

2

930

87

155

15

9

\section{ASH FUSION TEMPERATURES}

Initial deformation

Softening

tmosphere

Hemispherical

Fluid

\begin{tabular}{cr}
\multicolumn{2}{c}{$\begin{array}{c}\text { Reducing } \\
\text { atmosphere }\end{array}$} \\
$\frac{2}{1063^{\circ} \mathrm{C}} 1945^{\circ} \mathrm{F}$ \\
$1074^{\circ} \mathrm{C}$ & $1965^{\circ} \mathrm{F}$ \\
$1107^{\circ} \mathrm{C}$ & $2025^{\circ} \mathrm{F}$ \\
$1152^{\circ} \mathrm{C}$ & $2105^{\circ} \mathrm{F}$
\end{tabular}

Oxidizing

atmosphere

$1382^{\circ} \mathrm{C} 2520^{\circ} \mathrm{F}$

$1404^{\circ} \mathrm{C} \quad 2560^{\circ} \mathrm{F}$

$1416^{\circ} \mathrm{C} \quad 2580^{\circ} \mathrm{F}$

$1424^{\circ} \mathrm{C} \quad 2595^{\circ} \mathrm{F}$ 
The Penn State Coal Sample Bank and Database

Sample DECS-24

page 1 of 4

Illinois \#6 Seam (Herrin Seam)

hvCb rank

printed $8 / 24 / 95$

Macoupin County, IL

sampled $6 / 02 / 94$

\section{SAMPLE LOCATION}

Macoupin County, Illinois, "USA

Virden Township near Virden, Illinois

Interior Coal Province

Eastern Region

Farmersville (7.5') Topographic Quadrangle

Latitude $39^{\circ} 29^{\prime}$ 06" North, Longitude $89^{\circ} 44^{\prime} 40^{\prime \prime}$ West

\section{SAMPLE HISTORY}

Whole-Seam Channel Sample collected June 2, 1994 by Penn State

Mining method: underground

Coal Sample Bank reserve: $225 \mathrm{~kg}$ (497 1bs)

\section{SAMPLE INFORMATION --.}

Pennsytvanian

Kewanee Group

Carbondale Formation

Seam thickness at sample location: $229 \mathrm{~cm}$ ( $7 \mathrm{ft} 6 \mathrm{in.})$

Sample thickness:

Seam profile:

ROOF

$99 \mathrm{~cm}$

$58 \mathrm{~cm}$

$10 \mathrm{~cm}$

$61 \mathrm{~cm}$

FLOOR black shale

dull clarain, pyrite partings

bright clarain with vitrain

dull clarain, partings

very dull clarain, pyrite

soft gray clay 
The Penn State Coal Sample Bank and Database

Illinois \#6 Seam (Herrin Seam) Macoupin County, IL

hvCb rank

Sample DECS-24

page 2 of 4

printed $8 / 24 / 95$

sampled $6 / 02 / 94$

\section{PROXIMATE ANALYSIS}

$\%$ Moisture

\begin{tabular}{cc} 
as rec'd & dry \\
\hline 13.20 & \\
11.62 & 13.39 \\
35.44 & 40.83 \\
39.74 & 45.78
\end{tabular}

$\%$ Ash

$\%$ Vol. Matter

$\%$ Fixed Carbon

SULFUR FORMS

$\%$ Pyritic
$\%$ Sulfate
$\%$ Organic
$\%$ Total

$\%$ Total

\section{ULTIMATE ANALYSIS}

$\%$ Ash

\% Carbon

$\%$ Hydrogen

\% Nitrogen

$\%$ Total Sulfur

$\%$ Oxygen (diff.)
39.74

45.78

$\frac{\mathrm{dry}}{2.64}$

daf

2.64
0.25

3.05

2.64

0.29

5.53

3.05

6.38

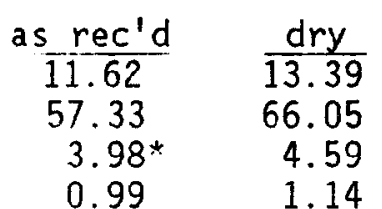

$4.80 \quad 5.53$

$8.07 * \quad 9.30$

47.14

52.86

45.51

54.49
10.74

daf $\frac{\text { dmmf(Parr) }}{(17.50 \% M M)}$

$76.26 \quad 80.06$

$5.30 \quad 5.56$

$1.32 \quad 1.38$

12.99

\section{MOISTURE}

$\%$ as received 13.20

$\%$ equilibrium 11.59

Dry \% Chlorine $=0.14 \quad$ Dry \% Carbon dioxide $=0.65$

\section{ELEMENTAL ANALYSIS}

\% Carbon

$\%$ Hydrogen

$\%$ Nitrogen

$\%$ Organic Sulfur

$\%$ Oxygen (diff.)

\% Mineral Matter

(incl. 4.94\% $\mathrm{FeS}_{2}$ )

\section{dry $\quad \frac{\text { dmmf(Mod.P) }}{(16.44 \% \text { MM) }}$}

$65.87 \quad 78.83$

$4.47 \quad 5.35$

$1.14 \quad 1.36$

$2.64 \quad 3.16$

$9.44 \quad 11.29$

16.44

\section{CALORIFIC VALUE (Gross)}

MM-containing

MM-free (Parr)

MM-free (mod. Parr)

Net, dmmf Btu/lb

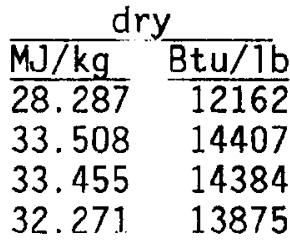

as rec'd moist equil. moist $\overline{\mathrm{MJ} / \mathrm{kg}} \overline{\mathrm{Btu} / \mathrm{Tb}} \quad \overline{\mathrm{MJ} / \mathrm{kg}} \quad \frac{\mathrm{Btu} / 1 \mathrm{~b}}{25 \mathrm{LO}}$ $\begin{array}{llll}24.554 & \overline{10557} & \overline{25.007} & \overline{10752}\end{array}$ $\begin{array}{llll}28.294 & 12165 & 28.915 & 12432\end{array}$ $\begin{array}{llll}28.305 & 12170 & 28.919 & 12434\end{array}$

Mott-Spooner difference $=307 \mathrm{Btu} / \mathrm{lb}$

ATOMIC RATIOS (dmmf)

Atomic $\mathrm{H} / \mathrm{C}$

$\frac{\text { Parr }}{0.835} \quad \frac{\text { mod. Parr }}{0.815}$

Atomic $0 / C$

0.122

0.108 
The Penn State Coal Sample Bank and Database

Illinois \#6 Seam (Herrin Seam)

hvCb rank

Sample DECS-24

page 3 of 4

printed $8 / 24 / 95$

sampled 6/02/94

\section{RANK CALCULATIONS}

ASTM Rank (equilibrium mo ïst.) hvCb Reflectance Rank hvCb

$$
\text { (as rec'd moist.) hucb }
$$

\section{MACERAL COMPOSITION (white light, volume \%)}

Vitrinite

TOTAL VITRINITE

Fusinite

Semifusinite

Macrinite

Micrinite

Sclerotinite

Inertodetrinite TOTAL INERTINITE

Sporinite

Resinite

Alginite

Cutinite

Liptodetrinite

TOTAL LIPTINITE

$$
\begin{aligned}
& \text { minera } 1- \\
& \frac{\text { free }}{90.2}
\end{aligned}
$$

mineral-

containing

81.8

81.8

2.5

3.4

0.0

0.9

0.0

0.0

6.8

2.3

3.1

0.0

0.8

0.0

0.0

6.2

Mineral matter (Parr, volume \%)
1.7
1.5

0.2

0.2

0.0

0.0

1.1

0.0

3.0

1.0

0.0

\section{7}

\section{REFLECTANCE DATA}

Vitrinite: Mean-max $R_{0}: 0.49 \%$

$\begin{array}{lllll}\text { Vtypes: } & \frac{V 3}{2.0} & \frac{V 4}{57.0} & \frac{V 5}{38.0} & \frac{V 6}{3.0}\end{array}$

\section{CAKING AND MECHANICAL PROPERTIES}

Free-swelling index

Hardgrove grindability index

Vickers' microhardness index

Washability data not available

\section{3}

57.8

n.d.
Gieseler Coal Plastometer: Initial softening $\quad 366^{\circ} \mathrm{C}$ Maximum fluidity $\quad 410^{\circ} \mathrm{C}$ Solidification $\quad 444^{\circ} \mathrm{C}$ Fluid temp. range $\quad 78^{\circ} \mathrm{C}$ Maximum fluidity $\quad 49 \mathrm{ddpm}$ 
The Penn State Coal Sample Bank and Database

Sample DECS-24

Illinois \#6 Seam (Herrin Seam)

hvCb rank

page 4 of 4

Macoupin County, IL

printed $8 / 24 / 95$

sampled $6 / 02 / 94$

\section{INORGANIC ELEMENT ANALYSIS}

Major Elements

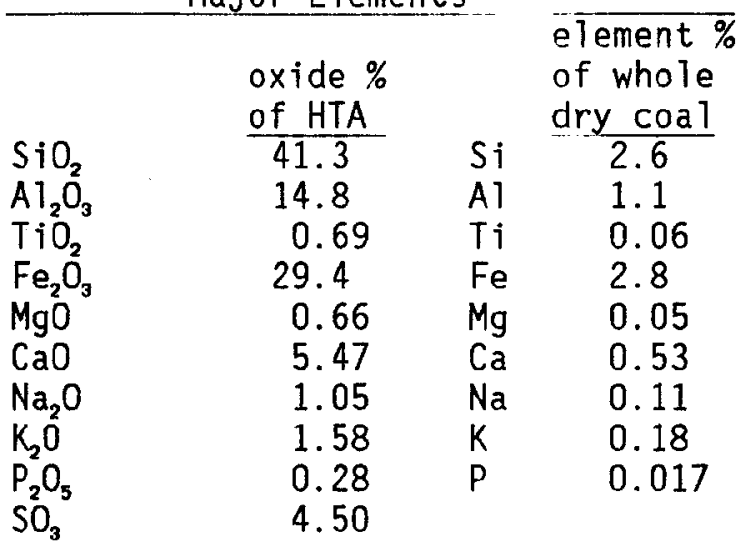

High-temperature ash (HTA) used for inorganic analysis $=13.68 \%$ of whole dry coal

\section{ASH FUSION TEMPERATURES}

Initial deformation
Softening
Hemispherical
Fluid

\begin{tabular}{|c|c|}
\hline \multicolumn{2}{|c|}{$\begin{array}{l}\text { Reducing } \\
\text { atmosphere }\end{array}$} \\
\hline $1060^{\circ} \mathrm{C}$ & $1940^{\circ} \mathrm{F}$ \\
\hline & \\
\hline & \\
\hline
\end{tabular}

Oxidizing

atmosphere

$\begin{array}{ll}1296^{\circ} \mathrm{C} & 2365^{\circ} \mathrm{F} \\ 1321^{\circ} \mathrm{C} & 2410^{\circ} \mathrm{F} \\ 1354^{\circ} \mathrm{C} & 2470^{\circ} \mathrm{F} \\ 1382^{\circ} \mathrm{C} & 2520^{\circ} \mathrm{F}\end{array}$

Trace Elements ppm whole dry $\frac{\text { coal }}{<0.3}$

As

$\mathrm{Ba}$

$\mathrm{Be}$

$\mathrm{Bi}$

$\mathrm{Cd}$

$\mathrm{Ce}$

$\mathrm{C} 1$

Co

$\mathrm{Cr}$

$\mathrm{Cu}$

$\mathrm{Ga}$

$\mathrm{Ge}$

$\mathrm{Hg}$

$\mathrm{Mn}$

$\mathrm{Nb}$

$\mathrm{Ni}$

$\mathrm{Pb}$

$\mathrm{Rb}$

$\mathrm{Sc}$

$\mathrm{Se}$

Sn

Sr

Th

V

$Y$

$\mathrm{Zn} \quad 240$

125

\section{0}

\section{3}

13

0.11

53

16

10

4

35

27

33

17

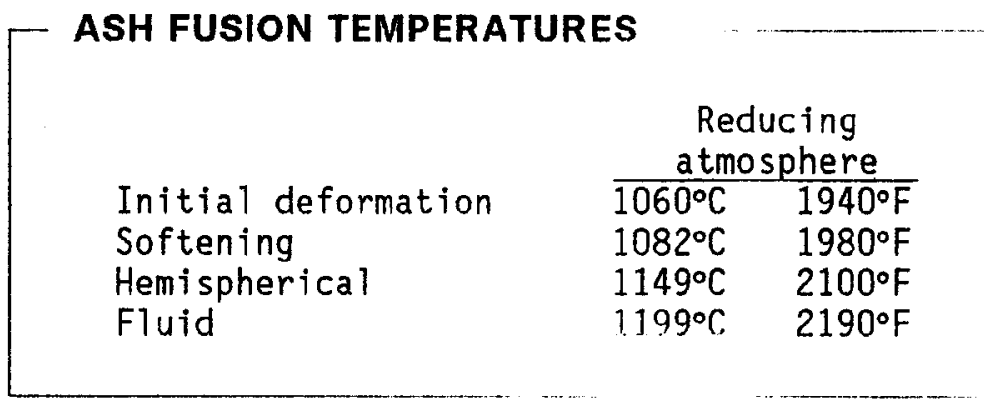


The Penn State Coal Sample Bank and Database

Sample DECS-25

page 1 of 4

Pust Seam

Richland County, MT

$\operatorname{lig} A$ rank

printed $8 / 24 / 95$

sampled $6 / 06 / 94$

\section{SAMPLE LOCATION}

Richland County, Montana, iISA

near Savage, Montana

Northern Great Plains Coal Province

Fort Union Region

Knife River Mine (7.5') Topographic Quadrangle

Latitude $47^{\circ} 28^{\prime} 2^{\prime \prime}$ North, Longitude $104^{\circ} 26^{\prime} 35^{\prime \prime}$ West

\section{SAMPLE HISTORY}

Whole-Seam Channel Sample cnllected June 6, 1994 by Penn State

Mining method: surface

sampled upper and lower parts 100 meters apart

Coal Sample Bank reserve: $176 \mathrm{~kg}$ (388 lbs)

\section{SAMPLE INFORMATION}

$\mathrm{Pa}$ leocene

Fort Union Formation

Seam thickness at sample location: $701 \mathrm{~cm}(23 \mathrm{ft} 0$ in.)

Sample thickness:

$701 \mathrm{~cm}(23 \mathrm{ft} 0 \mathrm{in.})$

Seam profile:

$137 \mathrm{~cm}$
$229 \mathrm{~cm}$
$61 \mathrm{~cm}$
$91 \mathrm{~cm}$
$61 \mathrm{~cm}$
$122 \mathrm{~cm}$

du11, brownish

du11, pyrite on cleat for 2"

parting, not sampled

dul 1

dull with shaly layers

du11 
The Penn State Coal Sample Bank and Database

Sample DECS-25

page 2 of 4

printed $8 / 24 / 95$

sampled $6 / 06 / 94$
Pust Seam

Richland County, MT

PROXIMATE ANALYSIS
ligA rank

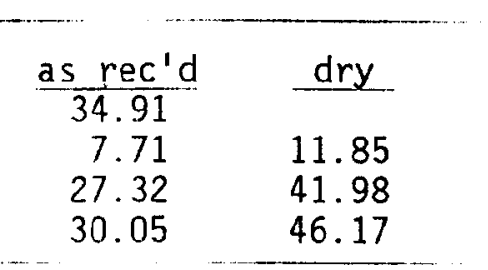

SULFUR FORMS

$\%$ Pyritic

$\%$ Sulfate

$\%$ Organic

$\%$ Total

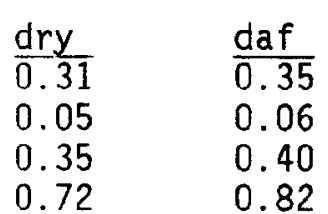

\begin{tabular}{cc}
\hline daf & dmmf(Parr) \\
& \\
47.62 & 46.94 \\
52.38 & 53.06 \\
\hline
\end{tabular}

\section{MOISTURE}

$\%$ as received 34.91

$\%$ equilibrium 34.82

\section{ULTIMATE ANALYSIS}

$\begin{array}{lcccc}\text { \% Ash } & \text { as rec'd } & \text { dry } & \text { daf } & \text { dmmf(Parr) } \\ \text { \% Carbon } & 7.71 & 11.85 & & \frac{13.19 \% M M)}{(13.85} \\ \text { \% Hydrogen } & 42.80 & 65.76 & 74.60 & 75.76 \\ \% \text { Nitrogen } & 2.99^{*} & 4.60 & 5.22 & 5.30 \\ \% \text { Total Sulfur } & 0.61 & 0.94 & 1.07 & 1.08 \\ \% \text { Oxygen (diff.) } & 0.47 & 0.72 & 0.82 & \\ & 10.50^{*} & 16.13 & 18.30 & 17.86 \\ & & \text { * excluding H and 0 in moisture }\end{array}$

Dry \% Chiorine $=0.04$ Dry \% Carbon dioxide $=1.38$

\section{ELEMENTAL ANALYSIS}

\% Carbon

\% Hydrogen

$\%$ Nitrogen

$\%$ Organic Sulfur

$\%$ Oxygen (diff.)

\% Mineral Matter

(inc1. $0.58 \% \mathrm{FeS}_{2}$ ) dry $\quad \frac{\operatorname{dmmf}(\text { Mod.P })}{(13.56 \% \mathrm{MM})}$

$65.38 \quad 75.64$

$4.45 \quad 5.15$

$0.94 \quad 1.09$

$0.35 \quad 0.40$

$15.32 \quad 17.72$

\section{CALORIFIC VALUE (Gross)}

MM-containing

MM-free (Parr)

MM-free (mod. Parr)

Net, dmmf Btu/1b

\begin{tabular}{|c|c|}
\hline \multicolumn{2}{|c|}{ dry } \\
\hline$\frac{\mathrm{MJ} / \mathrm{kg}}{25.461}$ & $\frac{\mathrm{Btu} / \mathrm{Tb}}{10947}$ \\
\hline 29.233 & 12569 \\
\hline 29.408 & \\
\hline 28.261 & 12 \\
\hline
\end{tabular}

Mott-Spooner difference $=-374 \mathrm{Btu} / \mathrm{Tb}$

as rec'd moist

$\overline{\mathrm{MJ} / \mathrm{kg}} \mathrm{Btu} / \mathrm{Tb}$

$16.572 \quad 7125$

$18.069 \quad 7769$

equit. moist

$\overline{\mathrm{MJ} / \mathrm{kg}} \mathrm{Btu} / \mathrm{lb}$

$16.595 \quad 7135$

18.097

7781

18.1487803

18.176

7815

\section{ATOMIC RATIOS (dmmf)}

Atomic $\mathrm{H} / \mathrm{C}$

$\frac{\text { Parr }}{0.840}$

Atomic $0 / C$

0.177

mod. Parr

0.818

0.176 
The Penn State Coal Sample Bank and Database

Pust Seam

Richland County, MT

lig A rank

Sample DECS-25

page 3 of 4

printed $8 / 24 / 95$

sampled $6 / 06 / 94$

\section{RANK CALCULATIONS}

ASTM Rank (equilibrium moist.) IigA

$$
\text { (as rec'd moist.) ligA }
$$

\section{MACERAL COMPOSITION (white light, volume \%)}

Textinite

Ulminite

Humodetrinite

Gelinite

Corpohuminite

TOTAL HUMINITE

Fusinite

Semifusinite

Macrinite

Micrinite

Sclerotinite

Inertodetrinite

TOTAL INERTINITE

Sporinite

Resinite

Alginite

Suberinite

Cutinite

Liptodetrinite

TOTAL LIPTINITE minera $1-$

free

0.0

42.0

30.9

0.2

1.2

74.3

3.4

10.5

1.4

0.7

0.6

5.5

22.1

2.0

0.6

0.0

0.8

0.2

0.0

\section{REFLECTANCE DATA}

Huminite: Mean-max $R_{0}: 0.23 \%$

$\begin{array}{llll}\text { Vtypes: } & \frac{V 1}{24.0} & \frac{V 2}{68.0} & \frac{V 3}{8.0}\end{array}$

\section{CAKING AND MECHANICAL PROPERTIES}

Free-swelling index

0

Hardgrove grindability index

59.3

Vickers' microhardness index n.d.

Gieseler Coal Plastometer: Initial softening n.d. Maximum fluidity n.d. Solidification n.d. Washability data not available

Fluid temp. range Maximum fluidity

n.d.

n.d. 
The Penn State Coal Sample Bank and Database

Sample DECS-25

Pust Seam

Richland County, MT

ligA rank

page 4 of 4

printed $8 / 24 / 95$

sampled $6 / 06 / 94$

\section{INORGANIC ELEMENT ANALYSIS}

\begin{tabular}{|c|c|c|c|}
\hline & $\begin{array}{l}\text { oxide } \% \\
\text { of HTA }\end{array}$ & & $\begin{array}{l}\text { element \% } \\
\text { of whole } \\
\text { dry coal }\end{array}$ \\
\hline & 25.7 & $S i$ & 1.3 \\
\hline $\mathrm{Al}_{2} \mathrm{O}_{3}$ & 16.1 & A 1 & 1.0 \\
\hline $\mathrm{TiO}_{2}$ & 0.58 & $\mathrm{Ti}$ & 0.04 \\
\hline $\mathrm{Fe}_{2} \mathrm{O}_{3}$ & 5.26 & $\mathrm{Fe}$ & 0.41 \\
\hline $\mathrm{MgO}^{\circ}$ & 8.20 & $\mathrm{Mg}$ & 0.55 \\
\hline $\mathrm{CaO}$ & 23.3 & $\mathrm{Ca}$ & 1.9 \\
\hline $\mathrm{Na}_{2} \mathrm{O}$ & 0.31 & $\mathrm{Na}$ & 0.03 \\
\hline $\mathrm{K}_{2} \mathrm{O}^{-}$ & 0.28 & K & 0.03 \\
\hline$P_{2}^{2} O_{5}$ & 0.41 & $P$ & 0.020 \\
\hline & 17.4 & & \\
\hline
\end{tabular}

High-temperature ash (HTA)

used for inorganic analysis

$=11.18 \%$ of whole dry coal

Trace Elements

ppm

ppm whole dry

HTA coal

$<0.3$

As

$\mathrm{Ba}$

$\mathrm{Be}$

Bi

$\mathrm{Cd}$

$\mathrm{Ce}$

Cl

$\mathrm{Co}$

$\mathrm{Cr}$

$\mathrm{Cu}$

Ga

$\mathrm{Ge}$

$\mathrm{Hg}$

La

$\mathrm{Mn}$

$\mathrm{Nb}$

$\mathrm{Ni}$

$\mathrm{Pb}$

$\mathrm{Rb}$

Sc

$\mathrm{Se}$

Sn

Sr

Th

U

$V$
$Y$

$Y b$

$\mathrm{Zn}$

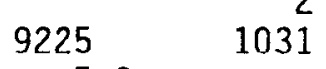

5.0

1031

$<0.3$

400

30

65

3

7

0.14

852

95

$<20$

$<2$

8.0

9

3

3552

397

55

6

$\mathrm{Zr}$

\section{ASH FUSION TEMPERATURES}

Initial deformation
Softening
Hemispherical
Fluid

\begin{tabular}{cc}
\multicolumn{2}{c}{ Reducing } \\
atmosphere \\
\hline $1243^{\circ} \mathrm{C}$ & $2270^{\circ} \mathrm{F}$ \\
$1249^{\circ} \mathrm{C}$ & $2280^{\circ} \mathrm{F}$ \\
$1254^{\circ} \mathrm{C}$ & $2290^{\circ} \mathrm{F}$ \\
$1268^{\circ} \mathrm{C}$ & $2315^{\circ} \mathrm{F}$
\end{tabular}

Oxidizing

atmosphere

$1232^{\circ} \mathrm{C} \quad 2250^{\circ} \mathrm{F}$

$1249^{\circ} \mathrm{C} \quad 2280^{\circ} \mathrm{F}$

$1271^{\circ} \mathrm{C} \quad 2320^{\circ} \mathrm{F}$

$1296^{\circ} \mathrm{C} \quad 2365^{\circ} \mathrm{F}$ 
The Penn State Coal Sample Bank and Database

Sample DECS-26

page 1 of 4

Wyodak Seam (Wyodak-Anderson)

subB rank

printed $8 / 24 / 95$

sampled $6 / 09 / 94$

Campbell County, WY

\section{SAMPLE LOCATION}

Campbell County, Wyoming, UISA

near Wright, Wyoming

Northern Great Plains Coal Province

Fort Union Region

Reno Reservoir (7.5') Topographic Quadrangle

Latitude $43^{\circ} 40^{\prime} 00^{\prime \prime}$ North, Longitude $105^{\circ} 15^{\prime} 00^{\prime \prime}$ West

\section{SAMPLE HISTORY}

Whole-Seam Run-of-mine Sample collected June 9, 1994 by Penn State

Mining method: surface

sampled from 38 cuts of automatic sampler

Coal Sample Bank reserve: $281 \mathrm{~kg}$ (621 1bs)

\section{SAMPLE INFORMATION}

Paleocene

Fort Union Formation

Seam thickness at sample location: $2134 \mathrm{~cm}$ ( $70 \mathrm{ft} 0$ in.) 
The Penn State Coal Sample Bank and Database

Sample DECS-26

page 2 of 4

Wyodak Seam (Wyodak-Anderson)

Campbell County, WY

subB rank printed $8 / 24 / 95$

sampled 6/09/94

PROXIMATE ANALYSIS

$\%$ Moisture

as rec'd

dry

daf dmmf(Parr)

$\%$ Ash

5.58

7.57

$\%$ Vol. Matter

33.06

44.86

\% Fixed Carbon

35.06

47.57

48.53

51.47

48.13

51.87

SULFUR FORMS

\begin{tabular}{lll} 
& $\frac{d}{\text { dry }}$ & $\frac{\text { daf }}{0.08}$ \\
$\%$ Pyritic & 0.07 & 0.01 \\
$\%$ Sulfate & 0.01 & 0.38 \\
$\%$ Organic & 0.35 & 0.47 \\
\hline Total & 0.43 & 0.43
\end{tabular}

- MOISTURE

$\%$ as received 26.30

$\%$ equilibrium 26.23

\section{ULTIMATE ANALYSIS}

\begin{tabular}{|c|c|c|c|c|}
\hline & as rec'd & dry & daf & $\frac{d m m f(P a r r)}{(\operatorname{lngM})}$ \\
\hline $\begin{array}{l}\% \text { Ash } \\
\% \text { Carbon }\end{array}$ & 5.58 & 7.57 & & ( $8.41 \% \mathrm{MM})$ \\
\hline \% Hydrogen & $\begin{array}{r}51.42 \\
4.16^{*}\end{array}$ & 69.77 & 75. 48 & 76.18 \\
\hline \% Nitrogen & 0.69 & $\begin{array}{l}5.03 \\
0.94\end{array}$ & 102 & 0.17 \\
\hline \% Total Sulfur & 0.32 & 0.43 & 0.47 & \\
\hline$\%$ Oxygen (diff.) & $11.53^{*}$ & 15.64 & 16.92 & 16.63 \\
\hline
\end{tabular}

Dry \% Chlorine $=0.0$

Dry \% Carbon dioxide $=0.12$

\section{ELEMENTAL ANALYSIS}

\% Carbon

\% Hydrogen

$\%$ Nitrogen

\% Organic Sulfur

$\%$ Oxygen (diff.)

\% Mineral Matter

(incl. 0.13\% $\mathrm{FeS}_{2}$ ) dry $\quad \frac{\text { dmmf(Mod.P) }}{(8.59 \% \mathrm{MM})}$

$69.74 \quad 76.29$

$5.55 \quad 6.07$

$0.94 \quad 1.03$

$0.35 \quad 0.38$

$14.83 \quad 16.23$

8.59

\section{CALORIFIC VALUE (Gross)}

\begin{tabular}{|c|c|c|c|c|c|c|}
\hline & & & as rec & moist & equil & moist \\
\hline & $\mathrm{MJ} / \mathrm{kg}$ & $\mathrm{Btu} / 1 \mathrm{~b}$ & $\mathrm{MJ} / \mathrm{kg}$ & $\mathrm{Btu} / 7 \mathrm{~b}$ & $\mathrm{MJ} / \mathrm{kg}$ & $\overline{B t u} / 1$ \\
\hline$y$-containing & $\overline{28.247}$ & $\overline{12145}$ & $\overline{20.819}$ & $\overline{8951}$ & $\overline{20.837}$ & 8959 \\
\hline -free (Parr) & 30.787 & 13237 & 22.156 & 9526 & 22.177 & 953 \\
\hline MM-free (mod. Parr) & 30.892 & 13282 & 22.219 & 9553 & 22.240 & 9562 \\
\hline & 29.559 & & & & - & 1 \\
\hline
\end{tabular}

ATOMIC RATIOS (dmmf)

Atomic $\mathrm{H} / \mathrm{C}$

Parr

Atomic $0 / C$

0.973

mod. Parr

0.164

0.956

0.160 
The Penn State Coal Sample Bank and Database

Wyodak Seam (Wyodak-Anderson)

Campbell County, WY

Sample DECS-26

page 3 of 4

subB rank

printed $8 / 24 / 95$

sampled $6 / 09 / 94$

\section{RANK CALCULATIONS}

ASTM Rank (equilibrium moist.) subB

$$
\text { (as rec'd moist.) subB }
$$

\section{MACERAL COMPOSITION (white light, volume \%)}

Textinite

Ulminite

Humodetrinite

Gelinite

Corpohuminite

TOTAL HUMINITE

Fusinite

Semifusinite

Macrinite

Micrinite

Sclerotinite

Inertodetrinite

TOTAL INERTINITE

Sporinite

Resinite

Alginite

Suberinite

Cutinite

Liptodetrinite

TOTAL LIPTINITE

\begin{tabular}{c} 
mineral- \\
free \\
\hline 0.0 \\
41.6 \\
41.1 \\
1.1 \\
1.9
\end{tabular}

3.3

3.1

0.3

0.6

0.1

2.3

9.7

3.6

0.4

0.0

0.6

0.0

0.0

4.6

\section{REFLECTANCE DATA}

Huminite: Mean-max $R_{0}: 0.29 \%$

$\begin{array}{llll}\text { Vtypes: } & \frac{V 1}{2.0} & \frac{V 2}{62.0} & \frac{V 3}{36.0}\end{array}$

\section{CAKING AND MECHANICAL PROPERTIES}

Free-swelling index

Hardgrove grindability index

Vickers' microhardness index

Washability data not available
0

47.2

n.d.
Gieseler Coal Plastometer: Initial softening n.d. Maximum fluidity n.d. Solidification n.d. Fluid temp. range n.d. Maximum fluidity n.d. 
The Penn State Coal Sample Bank and Database

Wyodak Seam (Wyodak-Anderson)

Campbell County, WY
Sample DECS-26

page 4 of 4

subB rank

sampled 6/09/94

INORGANIC ELEMENT ANALYSIS

Major Elements

\begin{tabular}{lccc}
\hline & $\begin{array}{c}\text { oxide } \% \\
\text { of } \mathrm{HTA}\end{array}$ & & $\begin{array}{l}\text { element \% } \\
\text { of whole } \\
\text { dry coal }\end{array}$ \\
$\mathrm{SiO}_{2}$ & 11.7 & $\mathrm{Si}$ & 1.0 \\
$\mathrm{Al}_{2} \mathrm{O}_{3}$ & 16.1 & $\mathrm{Al}$ & 0.6 \\
$\mathrm{TiO}_{2}$ & 1.27 & $\mathrm{Ti}$ & 0.05 \\
$\mathrm{Fe}_{2} \mathrm{O}_{3}$ & 4.84 & $\mathrm{Fe}$ & 0.23 \\
$\mathrm{MgO}_{\mathrm{CaO}}$ & 4.64 & $\mathrm{Mg}$ & 0.19 \\
$\mathrm{Ca}$ & 23.5 & $\mathrm{Ca}$ & 1.1 \\
$\mathrm{Na}_{2} \mathrm{O}$ & 1.80 & $\mathrm{Na}$ & 0.09 \\
$\mathrm{~K}_{2} \mathrm{O}$ & 0.40 & $\mathrm{~K}$ & 0.02 \\
$\mathrm{PO}_{2} \mathrm{O}_{5}$ & 0.89 & $\mathrm{P}$ & 0.026 \\
$\mathrm{SO}_{3}$ & 12.7 & &
\end{tabular}

High-temperature ash (HTA) used for inorganic analysis $=6.68 \%$ of whole dry coal

\section{ASH FUSION TEMPERATURES}

Initial deformation

Softening

Hemispherical

Fluid

\begin{tabular}{cc}
\multicolumn{2}{c}{$\begin{array}{c}\text { Reducing } \\
\text { atmosphere }\end{array}$} \\
\hline $1149^{\circ} \mathrm{C}$ & $2100^{\circ} \mathrm{F}$ \\
$1166^{\circ} \mathrm{C}$ & $2130^{\circ} \mathrm{F}$ \\
$1182^{\circ} \mathrm{C}$ & $2160^{\circ} \mathrm{F}$ \\
$1196^{\circ} \mathrm{C}$ & $2185^{\circ} \mathrm{F}$
\end{tabular}

Oxidizing a tmosphere $1185^{\circ} \mathrm{C} \quad 2165^{\circ} \mathrm{F}$ $1199^{\circ} \mathrm{C} \quad 2190^{\circ} \mathrm{F}$ $1213^{\circ} \mathrm{C} \quad 2215^{\circ} \mathrm{F}$ $1235^{\circ} \mathrm{C} \quad 2255^{\circ} \mathrm{F}$

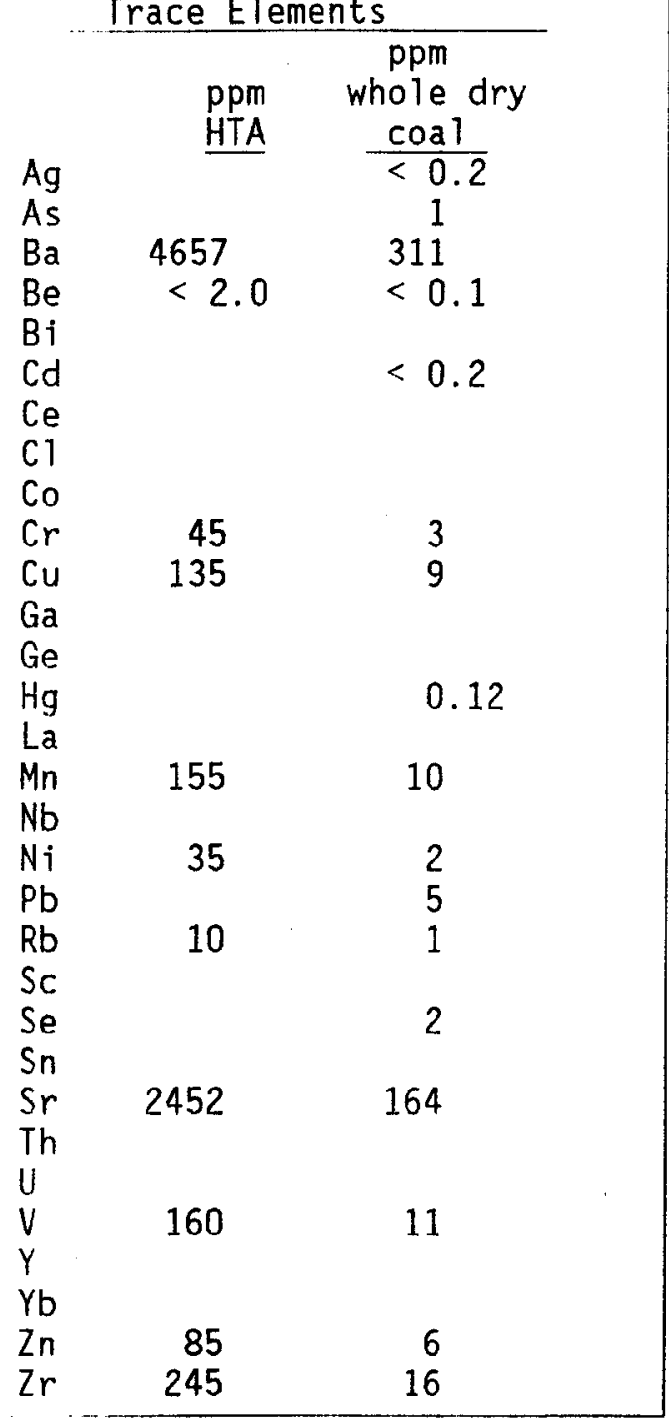


The Penn State Coal Sample Bank and Database

Deadman Seam

subA rank

Sample DECS-27

page 1 of 4

Sweetwater County, WY

printed $8 / 24 / 95$

sampled $6 / 10 / 94$

\section{SAMPLE LOCATION}

Sweetwater County, Wyoming; USA

near Point of Rocks, Wyoming

Rocky Mountain Coal Province

Green River Region

Twelvemile Well Topographic Quadrangle

Latitude $41^{\circ} 47^{\prime} 23^{\prime \prime}$ North, Longitude $108^{\circ} 44^{\prime} 45^{\prime \prime}$ West

\section{SAMPLE HISTORY}

Whole-Seam Run-of-mine Sample collected June 10, 1994 by Penn State Mining method: surface

sampled as $103.5^{\prime \prime}$ dia. auger drill holes

Coal Sample Bank reserve: $158 \mathrm{~kg}$ (350 ibs)

\section{SAMPLE INFORMATION}

Paleocene

Fort Union Formation

Seam thickness at sample location: $305 \mathrm{~cm}$ (10 ft 0 in.)

Sample thickness:

$305 \mathrm{~cm}(10 \mathrm{ft} 0 \mathrm{in.})$ 
The Penn State Coal Sample Bank and Database

Deadman Seam

Sweetwater County, WY

subA rank

Sample DECS-27

page 2 of 4

printed $8 / 24 / 95$

sampled $6 / 10 / 94$

- PROXIMATE ANALYSIS

$\begin{array}{lcccc} & \frac{\text { as rec'd }}{17.67} & \text { dry } & \text { daf } & \text { dmmf(Parr) } \\ \text { \% Moisture } & 11.45 & 13.91 & & \\ \% \text { Ash } & 29.42 & 35.73 & 41.50 & 40.59 \\ \% \text { Vol. Matter } & 41.46 & 50.36 & 58.50 & 59.41\end{array}$

\section{SULFUR FORMS}

$\begin{array}{lll}\text { \% Pyritic } & \frac{\text { dry }}{0.27} & \frac{\text { daf }}{0.31} \\ \% \text { Sulfate } & 0.00 & 0.00 \\ \% \text { Organic } & 0.44 & 0.51 \\ \% \text { Total } & 0.72 & 0.84\end{array}$

MOISTURE

$\%$ as received 17.67

$\%$ equilibrium 17.10

\section{ULTIMATE ANALYSIS}

$\%$ Ash

$\%$ Carbon

$\%$ Hydrogen

$\%$ Nitrogen

$\%$ Total Sulfur

$\%$ Oxygen (diff.)

\section{as rec'd}

11.45

55.17

$3.79 \%$

0.91

0.59

$10.42^{*}$ $\frac{d r y}{13.91}$

67.01

4.60

1.10

0.72

12.66

daf $\operatorname{dmmf}($ Parr $)$

(15.42\%MM)

$77.84 \quad 79.23$

$5.34 \quad 5.44$

1.28

1.30

14.71

14.04

Dry \% Chlorine $=0.0$

Dry \% Carbon dioxide $=0.78$

ELEMENTAL ANALYSIS

\% Carbon

$\%$ Hydrogen

\% Nitrogen

\% Organic Sulfur

\% Oxygen (diff.)

\% Mineral Matter

(incl. $0.51 \% \mathrm{FeS}_{2}$ ) dry $\quad \frac{d m m f(M o d . P)}{(15.85 \% \text { MM) }}$

(15.85\% MM)

$\begin{array}{ll}66.80 & 79.37\end{array}$

$4.42 \quad 5.26$

$1.10 \quad 1.31$

$0.44 \quad 0.52$

$11.39 \quad 13.54$

CALORIFIC VALUE (Gross)

\begin{tabular}{|c|c|c|c|c|c|c|}
\hline \multirow{6}{*}{$\begin{array}{l}\text { MM-containing } \\
\text { MM-free (Parr) } \\
\text { MM-free (mod. Parr) } \\
\text { Net, dmmf Btu/lb }\end{array}$} & \multicolumn{2}{|c|}{ dry } & \multicolumn{2}{|c|}{ as rec'd moist } & \multicolumn{2}{|c|}{ equil. moist } \\
\hline & $\mathrm{Mu} / \mathrm{kg}$ & Btu/1b & $\mathrm{MJ} / \mathrm{kg}$ & Btu/1b & $\mathrm{MJ} / \mathrm{kg}$ & Btu/Tb \\
\hline & 27.147 & 11672 & 22.351 & 9610 & 22.505 & 9676 \\
\hline & 31.996 & 13757 & 25.521 & 10973 & 25.724 & 11060 \\
\hline & 32.217 & 13852 & 25.670 & 11037 & 25.875 & 11125 \\
\hline & 31.041 & & & & & \\
\hline
\end{tabular}

\section{ATOMIC RATIOS (dmmf)}

Atomic $\mathrm{H} / \mathrm{C}$

$\frac{\text { Parr }}{0.825}$

mod. Parr

Atomic $\mathrm{O} / \mathrm{C}$

0.133

0.128 
The Penn State Coal Sample Bank and Database

Deadman Seam

Sweetwater County, WY

subA rank

Sample DECS-27

page 3 of 4

printed $8 / 24 / 95$

sampled $6 / 10 / 94$

\section{RANK CALCULATIONS}

ASTM Rank (equilibrium moïst..) subA Reflectance Rank hvcb

$$
\text { (as rec'd moist.) subA }
$$

\section{MACERAL COMPOSITION (white light, volume \%)}

Vitrinite

TOTAL VITRINITE

Fusinite

Semifusinite

Macrinite

Micrinite

Sclerotinite

Inertodetrinite

TOTAL INERTINITE

Sporinite

Resinite

Alginite

Cutinite

Liptodetrinite

TOTAL LIPTINITE

$$
\begin{aligned}
& \text { mineral- } \\
& \text { free } \\
& 81.0
\end{aligned}
$$

81.0

5.1

8.9

0.0

1.6

0.0

1.6

17.2

0.7

0.5

0.0

0.4

0.2

1.8 minera 1-

containing

74.4

74.4

Mineral matter (Parr, volume \%)

4.7

8.2

0.0

1.5

0.0

1. 5

15.9

\section{REFLECTANCE DATA}

Vitrinite: Mean-max $R_{0}: 0.46 \%$

$\begin{array}{llll}\text { Vtypes: } & V 3 & V 4 & \frac{V 5}{17.0}\end{array}$

\section{CAKING AND MECHANICAL PROPERTIES}

Free-swelling index

Hardgrove grindability index

Vickers' microhardness index

Washability data not available
0

57.0

n.d.

(1)

Gieseler Coal Plastometer: $\begin{array}{ll}\text { Initial softening } & \text { n.d. } \\ \text { Maximum fluidity } & \text { n.d. } \\ \text { Solidification } & \text { n.d. } \\ \text { Fluid temp. range } & \text { n.d. } \\ \text { Maximum fluidity } & \text { n.d. }\end{array}$
0.6

0.5

0.0

0.4

0.2

1.7

\subsection{8}


The Penn State Coal Sample Bank and Database

Deadman Seam

subA rank

Sample DECS-27

page 4 of 4

Sweetwater County, WY

printed $8 / 24 / 95$

sampled 6/10/94

\section{INORGANIC ELEMENT ANAL.YSIS}

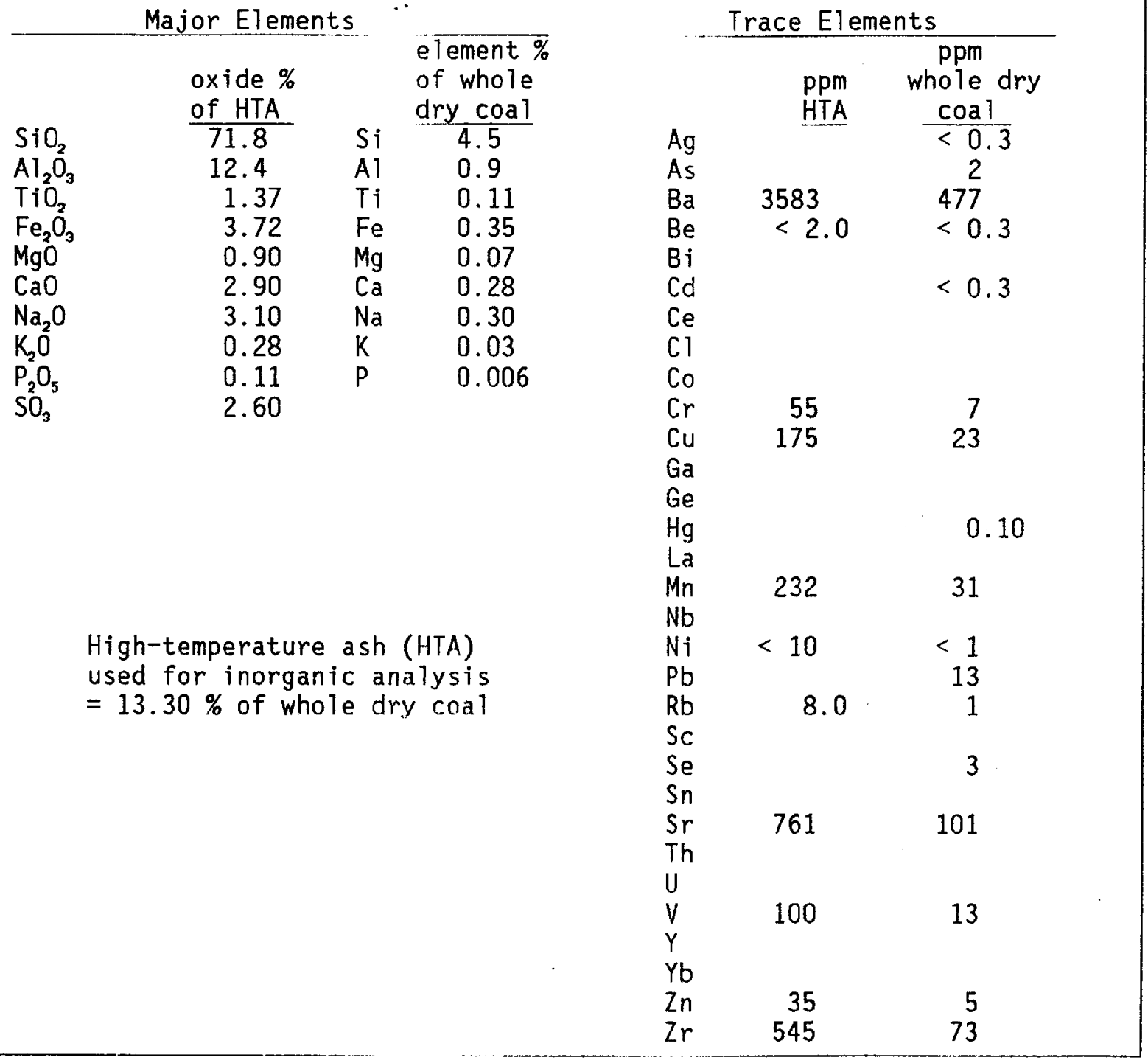

\section{ASH FUSION TEMPERATURES}

\begin{tabular}{|c|c|c|c|c|}
\hline \multirow{5}{*}{$\begin{array}{l}\text { Initial deformation } \\
\text { Softening } \\
\text { Hemispherical }\end{array}$} & \multicolumn{2}{|c|}{$\begin{array}{l}\text { Reducing } \\
\text { atmosphere }\end{array}$} & \multicolumn{2}{|c|}{$\begin{array}{l}\text { Oxidizing } \\
\text { atmosphere }\end{array}$} \\
\hline & $\overline{1385^{\circ} \mathrm{C}}$ & $2525^{\circ} \mathrm{F}$ & $\overline{1360^{\circ} \mathrm{C}}$ & $2480^{\circ} \mathrm{F}$ \\
\hline & $1427^{\circ} \mathrm{C}$ & $2600^{\circ} \mathrm{F}$ & $1404^{\circ} \mathrm{C}$ & $2560^{\circ} \mathrm{F}$ \\
\hline & $1466^{\circ} \mathrm{C}$ & $2670^{\circ} \mathrm{F}$ & $1438^{\circ} \mathrm{C}$ & $2620^{\circ} \mathrm{F}$ \\
\hline & $1488^{\circ} \mathrm{C}$ & $2710^{\circ} \mathrm{F}$ & $1460^{\circ} \mathrm{C}$ & $2660^{\circ} \mathrm{F}$ \\
\hline
\end{tabular}


The Penn State Coal Sample Bank and Database

Green Seam

hvCb rank

Navajo County, $A Z$

Sample DECS-28

page 1 of 4

printed $12 / 07 / 95$

sampled $6 / 13 / 94$

\section{SAMPLE LOCATION}

Navajo County, Arizona, USA

near Kayenta, Arizona

Rocky Mounta in Coal Province

San Juan River Region

Black Mesa

Long House Valley Topographic Quadrangle

Latitude $36^{\circ} 30^{\prime} 00^{\prime \prime}$ North, Longitude $110^{\circ} 22^{\prime} 00^{\prime \prime}$ West

\section{SAMPLE HISTORY}

Whole-Seam Channel Sample collected June 13, 1994 by Penn State

Mining method: surface

Blasted; no description. Resin visible in middle.

Coal Sample Bank reserve: $218 \mathrm{~kg}$ (482 1bs)

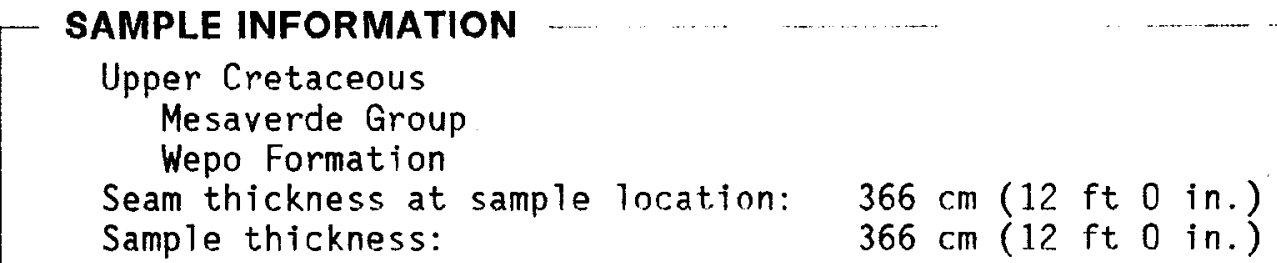


The Penn State Coal Sample Bank and Database

Sample DECS-28

page 2 of 4

Green Seam

Navajo County, AZ

hvCb rank

printed $12 / 07 / 95$

sampled $6 / 13 / 94$

PROXIMATE ANALYSIS

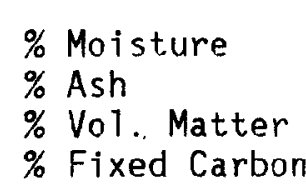

$$
\begin{gathered}
\text { as rec'd } \\
\frac{\text { 12.21 }}{5.34} \\
39.74 \\
42.71
\end{gathered}
$$$$
\text { dry }
$$$$
\text { daf dmmf(Parr) }
$$$$
6.08
$$

45.27

48.65

48.20

47.87

51.80

52.13

\section{SULFUR FORMS}

$\begin{array}{lll} & \frac{\text { dry }}{\text { daf }} \\ \% \text { Pyritic } & 0.02 & 0.02 \\ \% \text { Sulfate } & 0.00 & 0.00 \\ \% \text { Organic } & 0.38 & 0.40 \\ \% \text { Total } & 0.40 & 0.43\end{array}$

\section{ULTIMATE ANALYSIS}

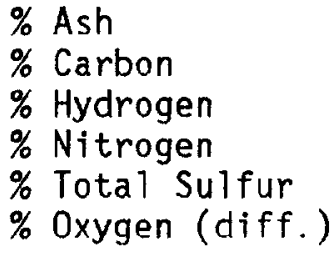

$\%$ Ash

\% Carbon

\% Hydrogen

$\%$ Oxygen (diff.)

Dry \% Chlorine $=0.0$

$$
\begin{array}{cr}
\text { as } \frac{\text { rec d }}{5.34} & \frac{\text { dry }}{6.08} \\
63.69 & 72.55 \\
4.52^{*} & 5.15 \\
1.03 & 1.17 \\
0.35 & 0.40 \\
12.86^{*} & 14.65
\end{array}
$$

daf $\quad \frac{\operatorname{dmmf}(\text { Parr })}{(6.79 \% M M)}$

77.25

77.83

5.48

5.52

1.25

1.26

0.43

15.60

15. 39

$\%$ as received

12.21

$\%$ equilibrium 13.00

Dry \% Carbon dioxide $=0.16$

\section{ELEMENTAL ANALYSIS}

\% Carbon

$\%$ Hydrogen

$\%$ Nitrogen

$\%$ Organic Sulfur

$\%$ Oxygen (diff.)

\% Mineral Matter

(incl. $0.04 \% \mathrm{FeS}_{2}$ ) dry $\frac{\text { dmmf(Mod.P) }}{(6.88 \% \text { MM) }}$

$72.51 \quad 77.86$

$\begin{array}{ll}5.07 & 5.45\end{array}$

$1.17 \quad 1.26$

$0.38 \quad 0.41$

$13.99 \quad 15.03$

\section{CALORIFIC VALUE (Gross)}

MM-containing

MM-free (Parr)

MM-free (mod. Parr)

Net, dmmf Btu/lb

6.88

\begin{tabular}{lr}
\multicolumn{2}{c}{ dry } \\
$\frac{\overline{M J} / \mathrm{kg}}{29.636}$ & $\overline{\mathrm{Btu} / \mathrm{Tb}}$ \\
31.743 & 13648 \\
31.822 & 13682 \\
30.631 & 13170
\end{tabular}

as rec'd moist

MJ/kg Btu/1b

26.017 $\overline{11186}$

$27.622 \quad 11876$

$27.687 \quad 11904$ equil. moist

MJ/kg Btu/1b

$25.784 \quad 11086$

$27.359 \quad 11763$

$27.422 \quad 11790$

Mott-Spooner difference $=11 \mathrm{Btu} / 1 \mathrm{~b}$

\section{ATOMIC RATIOS (dmmf)}

Atomic $\mathrm{H} / \mathrm{C}$

Parr mod. Parr

Atomic $0 / C$

$\begin{array}{ll}\frac{\text { Parr }}{0.853} & \text { mod. Parr } \\ 0.148 & 0.840 \\ 0.145\end{array}$


The Penn State Coal Sample Bank and Database

Sample DECS-28

page 3 of 4

Green Seam

hvCb rank

printed $12 / 07 / 95$

Navajo County, AZ

\section{RANK CALCULATIONS}

ASTM Rank (equilibrium moist.) hvCb

$$
\text { (as rec'd moist.) hvCb }
$$

MACERAL COMPOSITION (blue + white light, volume \%)

Vitrinite

TOTAL VITRINITE

Fusinite

Semifusinite

Macrinite

Micrinite

Sclerotinite

Inertodetrinite

TOTAL INERTINITE

Sporinite

Resinite

Alginite

Cutinite

Liptodetrinite

Exudatinite

Bituminite

Fluorinite

TOTAL LIPTINITE minera 1-

free

78.7

78.7

4.8

7.1

0.0

1.2

0.7

1.4

15.2

1.8

1.5

0.0

0.7

0.6

1.5

0.0

0.0

6.1

Mineral matter (Parr, volume \%) mineral-

containing

$\overline{7} \overline{6} . \overline{0}$

76.0

4.6

6.9

0.0

1.2

0.7

1.4

14.8

1.7

1.4

0.0

0.7

0.6

1.4

0.0

0.0

5.8

\section{REFLECTANCE DATA}

Vitrinite: Mean-max $R_{0}: 0.43 \%$

$\begin{array}{llll}\text { Vtypes: } & \frac{V}{2} & \frac{V 4}{77.0} & \frac{V 5}{1.0}\end{array}$

3.39

\section{CAKING AND MECHANICAL PROPERTIES}

Free-swelling index

Hardgrove grindability index

Vickers' microhardness index

Washability data not available
45.8

n.d.
0.5 Gieseler Coal Plastometer:
Initial softening
Maximum fluidity

Maximum fluidity

Solidification

Fluid temp. range

Maximum fluidity n.d.

n.d.

n.d.

n.d.

n.d. 
The Penn State Coal Sample Bank and Database

Green Seam

Navajo County, AZ

hvCb rank
Sample DECS-28

page 4 of 4

printed $12 / 07 / 95$

sampled $6 / 13 / 94$

INORGANIC ELEMENT ANALYSIS

$\begin{array}{lccc}\text { Major Elements } & \\ \text { oxide \% } & & \begin{array}{c}\text { element \% } \\ \text { of whole } \\ \text { of HTA coal }\end{array} \\ \mathrm{SiO}_{2} & 38.0 & \mathrm{Si} & 1.1 \\ \mathrm{Al}_{2} \mathrm{O}_{3} & 19.7 & \mathrm{Al} & 0.6 \\ \mathrm{TiO}_{2} & 0.98 & \mathrm{Ti} & 0.03 \\ \mathrm{Fe}_{2} \mathrm{O}_{3} & 5.15 & \mathrm{Fe} & 0.21 \\ \mathrm{MgO} & 2.35 & \mathrm{Mg} & 0.08 \\ \mathrm{CaO} & 15.9 & \mathrm{Ca} & 0.7 \\ \mathrm{Na}_{2} \mathrm{O} & 4.09 & \mathrm{Na} & 0.18 \\ \mathrm{KO}_{2} \mathrm{O} & 0.25 & \mathrm{~K} & 0.01 \\ \mathrm{P}_{2} \mathrm{O}_{5} & 0.64 & \mathrm{P} & 0.016 \\ \mathrm{SO}_{3} & 12.0 & & \end{array}$

Trace Elements $\mathrm{ppm}$

ppm whole dry

$\frac{\mathrm{coa} T}{<0.2}$

Ag

As

Ba

$\mathrm{Be}$

$\mathrm{Bi}$

$\mathrm{CH}$

$\mathrm{Ce}$

C1

Co

$\mathrm{Cr}$

$\mathrm{Cu}$

Ga

$\mathrm{Ge}$

$\mathrm{Hg}$

La

$\mathrm{Mn}$

High-temperature ash (HTA) used for inorganic analysis

$=5.85 \%$ of whole dry coal

$\mathrm{Ni}$

$\mathrm{Pb}$

$\mathrm{Rb}$

Sc

Se

Sn

Sr

Th

U

v

Y

Yb

Zn

30

65

2

$6001 \quad 351$

$=3.0<0.2$

$<0.2$

0.04

77

5

35

2

7.0

5

0.4

2

4313

252

90

5

25
300

2
18

2
25
-18

\section{ASH FUSION TEMPERATURES}

$\begin{array}{lll}\text { Initial deformation } & \begin{array}{c}\text { Reducing } \\ \text { atmosphere }\end{array} \\ \text { Softening } & 1138^{\circ} \mathrm{C} & 2080^{\circ} \mathrm{F} \\ \text { Hemispherical } & 1166^{\circ} \mathrm{C} & 2130^{\circ} \mathrm{F} \\ \text { Fluid } & 1191^{\circ} \mathrm{C} & 2175^{\circ} \mathrm{F} \\ & 1216^{\circ} \mathrm{C} & 2220^{\circ} \mathrm{F}\end{array}$

\begin{tabular}{|c|c|}
\hline \multicolumn{2}{|c|}{ Oxidizing } \\
\hline 216 & $2220^{\circ} \mathrm{F}$ \\
\hline & \\
\hline & \\
\hline
\end{tabular}


The Penn State Coal Sample Bank and Database

Sample DECS-29

page 1 of 4

Upper Banner \#3 Seam

huAb rank

printed $12 / 07 / 95$

Dickenson County, VA

\section{SAMPLE LOCATION}

Dickenson County, Virginiä, USA

near Carrie, Virginia

Eastern Coal Province

Appalachian Region

Duty (7.5') Topographic Quadrangle

Latitude $37^{\circ} 02^{\prime} 03^{\prime \prime}$ North, Longitude $82^{\circ} 11^{\prime} 10^{\prime \prime}$ West

\section{SAMPLE HISTORY}

Whole-Seam Channel Sample collected June 19, 1995 by Penn State

Mining method: surface

Mine Tife expected: 1 years

Sampled 100 meters from crop line - some oxidation

Coal Sample Bank reserve: $189 \mathrm{~kg}$ (418 lbs)

\section{SAMPLE INFORMATION}

Pennsylvanian

Norton Formation

Seam thickness at sample location: $\quad 55 \mathrm{~cm}$ (1 ft $10 \mathrm{in.})$

Sample thickness:

$55 \mathrm{~cm}(1 \mathrm{ft} 10 \mathrm{in.})$

Seam profile: 
The Penn State Coal Sample Bank and Database

Upper Banner \#3 Seam Dickenson County, VA
Sample DECS-29

page 2 of 4

printed $12 / 07 / 95$

sampled 6/19/95

\section{PROXIMATE ANALYSIS}

\% Moisture

$\%$ Ash

$\%$ Vol. Matter

\% Fixed Carbon
huAb rank

$\begin{array}{rrrc}\text { as } \frac{r e c}{\text { rec }} & \text { dry } & \text { daf } & \text { dmmf(Parr) } \\ 6.44 & & & \\ 6.20 & 6.36 & & \\ 33.46 & 34.30 & 36.63 & 36.16 \\ 57.89 & 59.34 & 63.37 & 63.84\end{array}$

\section{SULFUR FORMS}

$\%$ Pyritic
$\%$ Sulfate
$\%$ Organic
$\%$ Total

$\begin{array}{ll}\frac{\text { dry }}{0.09} & \frac{\text { daf }}{0.10} \\ 0.01 & 0.01 \\ 0.50 & 0.53 \\ 0.59 & 0.63\end{array}$

\section{MOISTURE}

$\%$ as received

$\%$ equilibrium 2.16

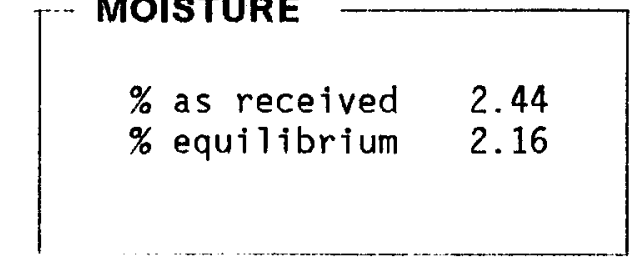

\section{ULTIMATE ANALYSIS}

\% Ash
$\%$ Carbon
$\%$ Hydrogen
$\%$ Nitrogen
$\%$ Total Sulfur
$\%$ Oxygen (diff.)

$$
\frac{\text { as rec'd }}{6.20} \quad \frac{d r y}{6.36}
$$

79.10

$5.05^{*}$

81.08

1.44

5.18

0.58

1.48

$5.18^{*} \quad 5.31$

0.59
5.31

* excluding $H$ and 0 in moisture

$\begin{array}{cc}\text { daf } & \text { dmmf(Parr) } \\ 86.59 & (7.19 \% \mathrm{MM}) \\ 5.53 & 57.36 \\ 1.58 & 1.58 \\ 0.63 & \\ 5.67 & 5.46 \\ 0 \text { in moisture }\end{array}$

Dry \% Ch1orine $=0.0$

\section{ELEMENTAL ANALYSIS}

\% Carbon

$\%$ Hydrogen

$\%$ Nitrogen

\% Organic Sulfur

$\%$ Oxygen (diff.)

\% Mineral Matter

(incl. $0.17 \% \mathrm{FeS}_{2}$ )

Dry \% Carbon dioxide $=0.63$

\section{CALORIFIC VALUE (Gross)}

dry $\quad \frac{\text { dmmf(Mod.P) }}{(7.23 \% M M)}$

$80.91 \quad 87.21$

$5.10 \quad 5.50$

$1.48 \quad 1.60$

$0.50 \quad 0.54$

$4.78 \quad 5.16$

7.23

\begin{tabular}{ll}
\multicolumn{2}{c}{ dry } \\
$\frac{\text { MJ/kg }}{33.825}$ & $\frac{\text { Btu/lb }}{14543}$ \\
36.371 & 15638 \\
36.448 & 15671 \\
35.243 & 15153
\end{tabular}

as rec'd moist

$\overline{\mathrm{M} J / \mathrm{kg}} \overline{\mathrm{Btu} / \mathrm{Tb}}$

32. $999 \quad 14188$

$35.418 \quad 15228$

$35.492 \quad 15260$

Mott-Spooner difference $=15 \mathrm{Btu} / 1 \mathrm{~b}$

\section{- ATOMIC RATIOS (dmmf)}

Atomic $\mathrm{H} / \mathrm{C}$

Parr mod. Parr

Atomic $\mathrm{O} / \mathrm{C}$

$\begin{array}{ll}0.767 & 0.757 \\ 0.047 & 0.044\end{array}$

$\begin{array}{lr}\frac{\text { equil }}{\text { Mul moist }} \\ \frac{\text { Mugg }}{33.094} & \frac{\text { Btu/1b }}{14229} \\ 35.527 & 15275 \\ 35.602 & 15307\end{array}$

$\begin{array}{lll}\text { MM-free (mod. Parr) } & 36.448 & 1567 \\ \text { Net, dmmf Btu/lb } & 35.243 & 15153\end{array}$ 
The Penn State Coal Sample Bank and Database

Sample DECS-29

page 3 of 4

Upper Banner \#3 Seam

hvAb rank

printed $12 / 07 / 95$

Dickenson County, VA

sampled $6 / 19 / 95$

RANK CALCULATIONS

ASTM Rank (equilibrium moist.) hvAb Reflectance Rank hvAb

(as rec'd moist.) hvab

MACERAL COMPOSITION (blue + white light, volume \%)

Vitrinite

TOTAL VITRINITE

Fusinite

Semifusinite

Macrinite

Micrinite

Sclerotinite

Inertodetrinite

TOTAL INERTINITE

Sporinite

Resinite

Alginite

Cutinite

Liptodetrinite

Exudatinite

Bituminite

Fluorinite

TOTAL LIPTINITE

$\begin{aligned} & \text { minera } 1- \\ & \text { free }\end{aligned}$
71.1

71.1

3.6

8.7

0.3

8.4

0.0

1.0

22.0

5.4

0.9

0.0

0.5

0.1

0.0

0.0

0.0

6.9 mineral-

containing

$\overline{6} \overline{8} \overline{5}$

68.5

Mineral matter (Parr, volume \%)

3.4

8.4

0.3

8.1

0.0

1.0

21.2

5.2

0.9

0.0

0.5

0.1

0.0

0.0

0.0

6.7

3.60

\section{REFLECTANCE DATA}

Vitrinite: Mean-max $R_{0}: 1.00 \%$

Vtypes: $\quad \frac{V 8}{1.0} \quad \frac{V 9}{55.0} \quad \frac{V 10}{44.0}$

\section{CAKING AND MECHANICAL PROPERTIES}

Free-swelling index

Hardgrove grindability index

Vickers' microhardness index

Washability data not available
8

55.5

n.d.
Gieseler Coal Plastometer:

$\begin{array}{lr}\text { Initial softening } & 397^{\circ} \mathrm{C} \\ \text { Maximum fluidity } & 447^{\circ} \mathrm{C} \\ \text { Solidification } & 487^{\circ} \mathrm{C} \\ \text { Fluid temp. range } & 90^{\circ} \mathrm{C} \\ \text { Maximum fluidity } & 8942 \mathrm{ddpm} \\ \text { erage of } 6 \text { runs } & \end{array}$


The Penn State Coal Sample Bank and Database

Upper Banner \#3 Seam

hvAb rank

Sample DECS-29

Dickenson County, VA

INORGANIC ELEMENT ANALYSIS

$\begin{array}{lccc}\text { Major Elements } & \\ \text { oxide \% } & & \begin{array}{l}\text { element \% } \\ \text { of whole } \\ \text { of } \mathrm{HTA}\end{array} \\ \mathrm{SiO}_{2} & 48.5 & \mathrm{Si} & \overline{1} . \overline{4} \\ \mathrm{Al}_{2} \mathrm{O}_{3} & 27.9 & \mathrm{Al} & 0.9 \\ \mathrm{TiO}_{2} & 0.95 & \mathrm{Ti} & 0.04 \\ \mathrm{Fe}_{2} \mathrm{O}_{3} & 10.7 & \mathrm{Fe} & 0.5 \\ \mathrm{MgO}^{2} & 1.72 & \mathrm{Mg} & 0.06 \\ \mathrm{CaO} & 3.81 & \mathrm{Ca} & 0.17 \\ \mathrm{Na}_{2} \mathrm{O} & 0.70 & \mathrm{Na} & 0.03 \\ \mathrm{~K}_{2} \mathrm{O} & 2.53 & \mathrm{~K} & 0.13 \\ \mathrm{P}_{2} \mathrm{O}_{5} & 0.12 & \mathrm{P} & 0.003 \\ \mathrm{SO}_{3} & 1.60 & & \end{array}$

High-temperature ash (HTA) used for inorganic analysis $=6.19 \%$ of whole dry coal
Trace Elements

$$
\mathrm{ppm}
$$

ppm whole dry

$\mathrm{Ag}$

As

Ba

$\mathrm{Be}$

$\mathrm{Bi}$

$\mathrm{CA}$

$\mathrm{Ce}$

C. 1

Co

$\mathrm{Cr}$

Cus

Ga

Ge

$\mathrm{Hg}$

La

$\mathrm{Mn}$

$\mathrm{Nb}$

$\mathrm{Ni}$

$\mathrm{Pb}$

$\mathrm{Rb}$

Sc

$\mathrm{Se}$

Sn

Sr

Th

U

V

Y

$Y b$

$\mathrm{Zn}$

$$
\text { HTA }
$$

1702

25 coa 1 $<0.2$ 4 105 2

$<0.2$

120

240

7

15

0.04

310

19

140

50

1353

84

170

11

110

240

\begin{tabular}{|c|c|c|}
\hline & \multicolumn{2}{|c|}{$\begin{array}{c}\text { Reducing } \\
\text { atmosphere } \\
\end{array}$} \\
\hline Initial deformation & $1216^{\circ} \mathrm{C}$ & $2220^{\circ} \mathrm{F}$ \\
\hline & $1332^{\circ} \mathrm{C}$ & $2430^{\circ} \mathrm{F}$ \\
\hline rical & $1382^{\circ} \mathrm{C}$ & $2520^{\circ} \mathrm{F}$ \\
\hline & $1427^{\circ} \mathrm{C}$ & $2600^{\circ} \mathrm{F}$ \\
\hline
\end{tabular}

\section{ASH FUSION TEMPERATURES}

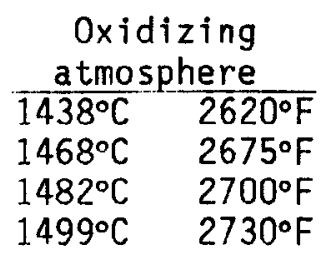


The Penn State Coal Sample Bank and Database

Splash Dam Seam Buchanan County, VA

\section{SAMPLE LOCATION}

Buchanan County, Virginia," USA

near Harman, Virginia

Eastern Coal Province

Appalachian Region

Harman (7.5') Topographic Quadrangle Latitude $37^{\circ} 16^{\prime} 24^{\prime \prime}$ North, Longitude $82^{\circ} 12^{\prime} 51^{\prime \prime}$ West
Sample DECS-30

page 1 of 4

mvb rank

\section{SAMPLE HISTORY}

Whole-Seam Channel Sample collected June 20, 1995 by Penn State

Mining method: underground

Coal Sample Bank reserve: $191 \mathrm{~kg}$ (423 1bs)

\section{SAMPLE INFORMATION}

Pennsylvanian

Norton Formation

Seam thickness at sample location: $83 \mathrm{~cm}$ (2 ft 9 in.)

Sample thickness:

Seam profile:

ROOF

$13 \mathrm{~cm}$

$15 \mathrm{~cm}$

$56 \mathrm{~cm}$

FLOOR black mudstone

bright clarain, vit., partings

same, 1/4" parting at base

bright clarain, thick vitrain

includes occasional $1^{\prime \prime}$ coal 
The Penn State Coal Sample Bank and Database

Splash Dam Seam

Buchanan County, VA

mvb rank

Sample DECS-30

page 2 of 4

printed $12 / 07 / 95$

sampled $6 / 20 / 95$

PROXIMATE ANALYSIS

\% Moisture

$\%$ Ash

\% Vol. Matter

$\%$ Fixed Carbon

\begin{tabular}{|c|c|}
\hline as $\frac{\mathrm{rec}^{\prime} \mathrm{d}}{2.06}$ & dry \\
\hline 3.81 & \\
\hline 29.51 & \\
\hline
\end{tabular}

65.98 daf $\quad \operatorname{dmmf(Parr})$

$31.35 \quad 30.94$

\section{SULFUR FORMS}

\% Pyritic

\% Sulfate

$\%$ Organic

$\%$ Total $\frac{\text { dry }}{0.14}$

0.00

0.65

0.79 daf

$\overline{0.15}$

0.00

0.68

0.82
69.04

\section{ULTIMATE ANALYSIS}

$\%$ Ash

\% Carbon

\% Hydrogen

\% Nitrogen

\% Total Sulfur

$\%$ Oxygen (diff.)

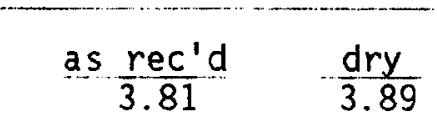

$82.67 \quad 84.41$

$5.04 * \quad 5.15$

1.48

0.77

$4.16^{*}$

1.51

0.79

4.25

* excluding $H$ and $O$ in moisture

\section{MOISTURE}

$\%$ as received

$\%$ equilibrium

2.06

5.18

Dry \% Chlorine $=0.07$ Dry \% Carbon dioxide $=0.59$

\section{ELEMENTAL ANALYSIS}

\% Carbon

$\%$ Hydrogen

\% Nitrogen

\% Organic Sulfur

\% Oxygen (diff.)

\% Mineral Matter

(incl. $0.26 \% \mathrm{FeS}_{2}$ ) dry $\quad \frac{d m m f(\text { Mod.P) }}{(4.50 \% \text { MM) }}$

$84.25 \quad 88.22$

$5.10 \quad 5.34$

$1.51 \quad 1.58$

$0.65 \quad 0.68$

$3.99 \quad 4.18$ daf $\frac{d m m f(P a r r)}{(4.64 \% M M)}$

$87.83 \quad 88.51$

$\begin{array}{ll}5.36 & 5.40\end{array}$

$1.57 \quad 1.58$

0.82

4.42

4.50

4.50

\section{CALORIFIC VALUE (Gross)}

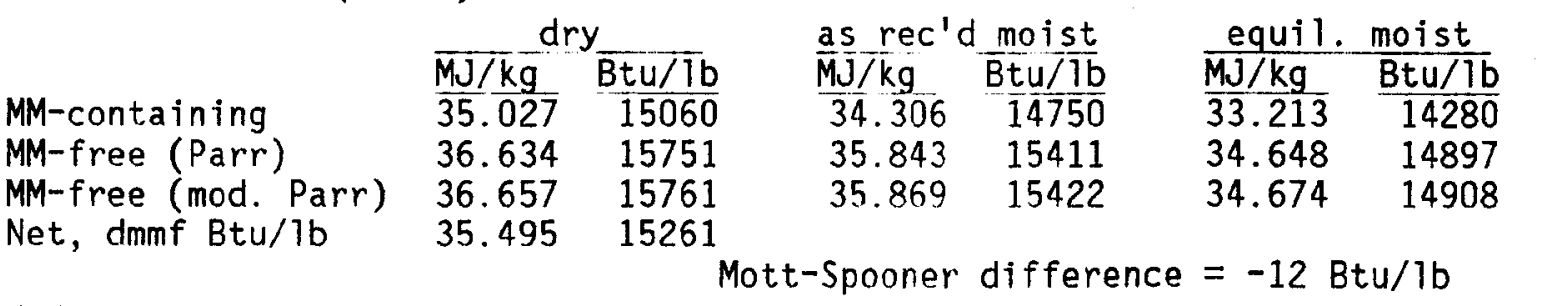

\section{ATOMIC RATIOS (dmmf)}

Atomic $\mathrm{H} / \mathrm{C}$

\begin{tabular}{cc} 
Parr & mod. Parr \\
\hdashline 0.733 & 0.727 \\
0.038 & 0.036
\end{tabular}

Atomic $\mathrm{O} / \mathrm{C}$

0.038

0.036 
The Penn State Coal Sample Bank and Database

Sample DECS-30

page 3 of 4

Splash Dam Seam

mub rank

printed $12 / 07 / 95$

Buchanan County, VA

sampled $6 / 20 / 95$

\section{RANK CALCULATIONS}

ASTM Rank (equilibrium moíst.) mvb

$$
\text { (as rec'd moist.) mvb }
$$

\section{MACERAL COMPOSITION (white light, volume \%)}

Vitrinite

TOTAL VITRINITE

Fusinite

Semifusinite

Macrinite

Micrinite

Sclerotinite

Inertodetrinite

TOTAL INERTINITE

Sporinite

Resinite

Alginite

Cutinite

Liptodetrinite

TOTAL LIPTINITE mineral-

free

$\overline{76.8}$

76.8

3.1

10.9

0.1

5.0

0.0

0.5

3.4

0.1

0.0

0.1

0.0

3.6 mineral-

containing

$\overline{7} \overline{0} . \overline{0}$

75.0

3.0

10.7

0.1

4.9

0.0

0.5

19.2

Mineral matter (Parr, volume \%)

3.3

0.1

0.0

0.1

0.0

3.5

\section{REFLECTANCE DATA}

Vitrinite: Mean-max $R_{0}: 1.16 \%$

Vtypes: $\quad \frac{V 10}{7.0} \quad \frac{V 11}{72.0} \quad \frac{V 12}{21.0}$

\subsection{9}

\section{CAKING AND MECHANICAL PROPERTIES}

Free-swelling index

Hardgrove grindability index

Vickers' microhardness index Washability data not available

\section{8}

74.7

n.d.
Gieseler Coal Plastometer:

Initial softening $\quad 383^{\circ} \mathrm{C}$

Maximum fluidity $\quad 458^{\circ} \mathrm{C}$

Solidification $\quad 500^{\circ} \mathrm{C}$

Fluid temp. range $117^{\circ} \mathrm{C}$

Maximum fluidity 28188 ddpm 
The Penn State Coal Sample Bank and Database

Splash Dam Seam

Buchanan County, VA

\section{INORGANIC ELEMENT ANALYSIS}

\begin{tabular}{|c|c|c|c|}
\hline \multirow{2}{*}{$\ldots \ldots \ldots}$. & \multicolumn{3}{|c|}{ Major Elements } \\
\hline & oxide \% & & $\begin{array}{l}\text { element \% } \\
\text { of whole }\end{array}$ \\
\hline $\mathrm{SiO}_{2}$ & 46.8 & Si & 0.9 \\
\hline $\mathrm{Al}_{2} \mathrm{O}_{3}$ & 28.8 & A1 & 0.6 \\
\hline $\mathrm{TiO}_{2}$ & 1.77 & $\mathrm{Ti}$ & 0.04 \\
\hline $\mathrm{Fe}_{3} \mathrm{O}_{3}$ & 13.9 & $\mathrm{Fe}$ & 0.4 \\
\hline $\mathrm{MgO}$ & 0.90 & $\mathrm{Mg}$ & 0.02 \\
\hline $\mathrm{CaO}$ & 1.94 & $\mathrm{Ca}$ & 0.05 \\
\hline $\mathrm{Na}_{2} \mathrm{O}$ & 2.15 & $\mathrm{Na}$ & 0.06 \\
\hline $\mathrm{K}_{2} \mathrm{O}$ & 1.52 & $k$ & 0.05 \\
\hline $\mathrm{P}_{2} \mathrm{O}_{5}$ & 0.52 & $P$ & 0.009 \\
\hline $\mathrm{SO}_{3}$ & 0.20 & & \\
\hline
\end{tabular}

High-temperature ash (HTA) used for inorganic analysis $=3.91 \%$ of whole dry coal mvb rank

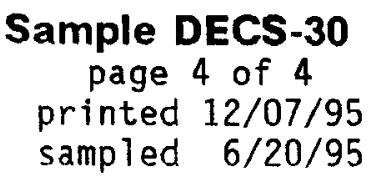

Trace Elements

ppm

ppm whole dry

HTA coal

$\mathrm{Ag}$

As

Ba

$\mathrm{Be}$

$\mathrm{Bi}$

Cd

$\mathrm{Ce}$

$\mathrm{Cl}$

Co

$\mathrm{Cr}$

$\mathrm{Cu}$

Ga

Ge

$\mathrm{Hg}$

La

$\mathrm{Mn}$

$\mathrm{Nb}$

$\mathrm{Ni}$

$\mathrm{Pb}$

$\mathrm{Rb}$

SC

Se

Sn

Sr

Th

U

V

Y

$Y b$

Zn
2060

20
19

81

1

0.10

700

120

290

5

11

0.11

387

15

140

30

4

1

2

1945

76

230

9

90
340

4

13

\section{ASH FUSION TEMPERATURES}

\begin{tabular}{lll} 
Initial deformation & \multicolumn{2}{c}{$\begin{array}{c}\text { Reducing } \\
\text { atmosphere }\end{array}$} \\
\cline { 2 - 3 } Softening & $1399^{\circ} \mathrm{C}$ & $2550^{\circ} \mathrm{F}$ \\
Hemispherical & $1443^{\circ} \mathrm{C}$ & $2630^{\circ} \mathrm{F}$ \\
Fluid & $1477^{\circ} \mathrm{C}$ & $2690^{\circ} \mathrm{F}$ \\
& $1510^{\circ} \mathrm{C}$ & $2750^{\circ} \mathrm{F}$
\end{tabular}

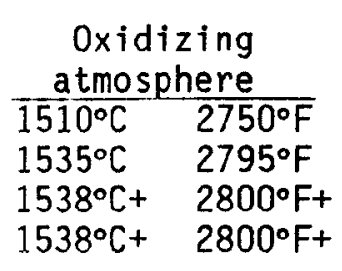


The Penn State Coal Sample Bank and Database

Pond Creek Seam

hvAb rank

Sample DECS-31

page 1 of 4

Pike County, KY

printed $12 / 07 / 95$

sampled $6 / 21 / 95$

\section{SAMPLE LOCATION}

Pike County, Kentucky, USA near Kimper, Kentucky

Eastern Coal Province Appalachian Region

Lick Creek (7.5') Topographic Quadrangle Latitude $37^{\circ} 29^{\prime} 00^{\prime \prime}$ North, Longitude $82^{\circ} 15^{\prime} 21^{\prime \prime}$ West

\section{SAMPLE HISTORY}

Whole-Seam Channel Sample collected June 21, 1995 by Penn State

Mining method: underground

Coal Sample Bank reserve: $170 \mathrm{~kg}$ (375 lbs)

\section{SAMPLE INFORMATION}

Pennsylvanian

\section{Breathitt Formation}

Seam thickness at sample location: $145 \mathrm{~cm}$ (4 ft 9 in.)

Sample thickness:

Seam profile:

$\begin{array}{rl}\text { ROOF } & \text { gray shale, plant fossils } \\ 33 \mathrm{~cm} & 4 \mathrm{~cm} \text { durain } 29 \mathrm{~cm} \text { du1l clarain } \\ 10 \mathrm{~cm} & 5 \mathrm{~cm} \text { fusain, } 5 \mathrm{~cm} \text { dull clarain } \\ 33 \mathrm{~cm} & \text { bright clarain with shale } \\ 25 \mathrm{~cm} & \text { bright clarain } \\ 33 \mathrm{~cm} & \text { clarain with shale stringers } \\ 10 \mathrm{~cm} & \text { durain } \\ \text { FLOOR } & \text { gray shale }\end{array}$


The Penn State Coal Sample Bank and Database

Pond Creek Seam

hvAb rank

Sample DECS-31

page 2 of 4

Pike County, KY

printed $12 / 07 / 95$

sampled $6 / 21 / 95$

\section{PROXIMATE ANALYSIS}

\% Moisture

$\begin{array}{cc}\text { as } \frac{\text { rec }}{2.32} & \text { dry } \\ 10.64 & 10.89 \\ 32.52 & 33.29 \\ 54.52 & 55.82\end{array}$

daf $\quad$ dmmf(Parr)

$\%$ Ash

$\%$ Vol. Matter

\% Fixed Carbon

54.52

55.82

$\begin{array}{ll}37.36 & 36.60 \\ 62.64 & 63.40\end{array}$

\section{SULFUR FORMS}

$\begin{array}{lll} & \text { dry } & \text { daf } \\ \text { \% Pyritic } & 0.11 & 0.12 \\ \% \text { Sulfate } & 0.01 & 0.01 \\ \% \text { Organic } & 0.49 & 0.55 \\ \% \text { Total } & 0.60 & 0.67\end{array}$

\section{MOISTURE}

$\%$ as received

2.32

$\%$ equilibrium

\section{ULTIMATE ANALYSIS}

$\%$ Ash

\% Carbon

\% Hydrogen

\% Nitrogen

$\%$ Total Sulfur

\% Oxygen (diff.)

\section{$\frac{\text { as rec'd }}{10.64} \quad \frac{\text { dry }}{10.89}$}

74.55

$4.74^{*}$

1.28

0.59

$5.89 *$

76.32

4.85

1. 31

0.60

6.03

* excluding $H$ and 0 in moisture

daf

$\frac{\operatorname{dmmf}(P a r r)}{(12.09 \% \mathrm{MM})}$

$85.65 \quad 86.82$

$5.44 \quad 5.52$

1.47

1.49

0.67

6.77

6.18

Dry \% Chlorine $=0.09$ Dry \% Carbon dioxide $=0.57$

\section{ELEMENTAL ANALYSIS}

\% Carbon

$\%$ Hydrogen

$\%$ Nitrogen

$\%$ Organic Sulfur

$\%$ Oxygen (diff.)

\% Mineral Matter

(incl. $0.21 \% \mathrm{FeS}_{2}$ ) dry $\quad \frac{d m m f(\text { Mod.P) }}{(12.40 \% \text { MM) }}$

$76.16 \quad 86.95$

$4.71 \quad 5.38$

$4.71 \quad 1.50$

$0.49 \quad 0.56$

$4.92 \quad 5.62$

\section{CALORIFIC VALUE (Gross)}

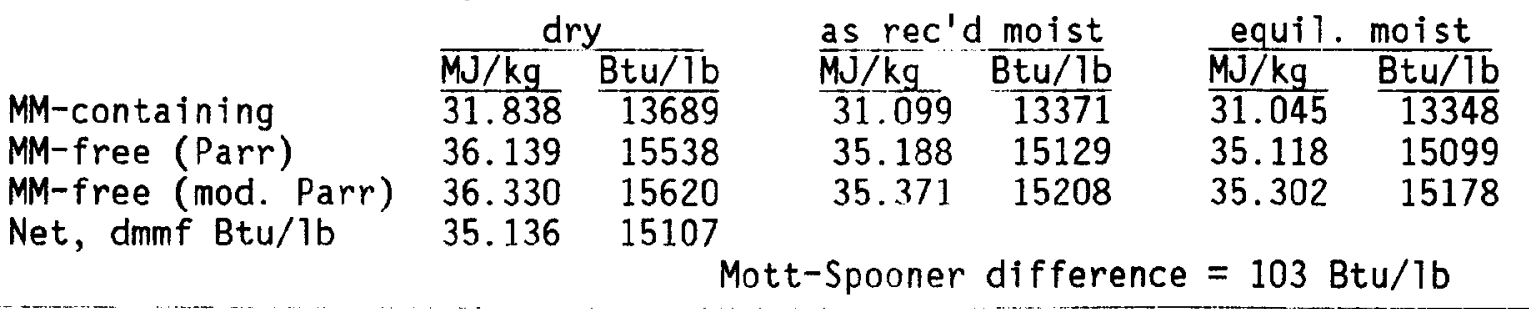

\section{ATOMIC RATIOS (dmmf)}

Atomic $\mathrm{H} / \mathrm{C}$

$\frac{\text { Parr }}{0.763} \quad \frac{\text { mod. Parr }}{0.743}$

Atomic $\mathrm{O} / \mathrm{C}$

0.053

0.049 
The Penn State Coal Sample Bank and Database

Pond Creek Seam

hvAb rank

Sample DECS-31

page 3 of 4

Pike County, KY

printed $12 / 07 / 95$

sampled $6 / 21 / 95$

\section{RANK CALCULATIONS}

ASTM Rank (equilibrium moist.) hvAb

Reflectance Rank hvAb

$$
\text { (as rec'd moist.) hvAb }
$$

\section{MACERAL COMPOSITION (blue + white light, volume \%)}

Vitrinite

TOTAL VITRINITE

Fusinite

Semifusinite

Macrinite

Micrinite

Sclerotinite

Inertodetrinite

TOTAL INERTINITE

Sporinite

Resinite

Alginite

Cutinite

Liptodetrinite

Exudatinite

Bituminite

Fluorinite

TOTAL LIPTINITE

$$
\begin{aligned}
& \begin{array}{l}
\text { minera 1- } \\
\text { free }
\end{array} \\
& 72.9
\end{aligned}
$$

72.9

mineral-

containing

68.4

68.4
5.0
4.7

7.4

6.9

0.0

0.0

5.2

4.9

0.0

0.0

1.4

19.0

17.8

7.1

0.5

6.6

0.0

0.5

0.0

0.0

0.4

0.0

0.1

0.4

0.0

0.0

8.1

0.1

0.0

0.0

7.6

Mineral matter (Parr, volume \%)

6.22

\section{REFLECTANCE DATA}

Vitrinite: Mean-max $R_{0}: 0.99 \%$

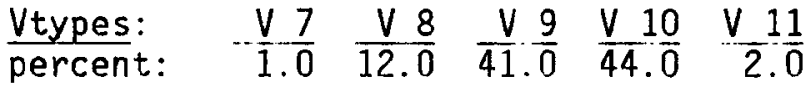

\section{CAKING AND MECHANICAL PROPERTIES}

Free-swelling index 8

Hardgrove grindability index Vickers' microhardness index

54.1

Washability data not available

n.d.

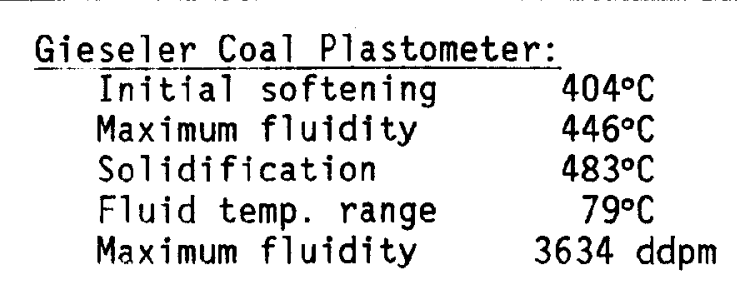


The Penn State Coal Sample Bank and Database

Pond Creek Seam

Pike County, KY

INORGANIC ELEMENT ANALYSIS

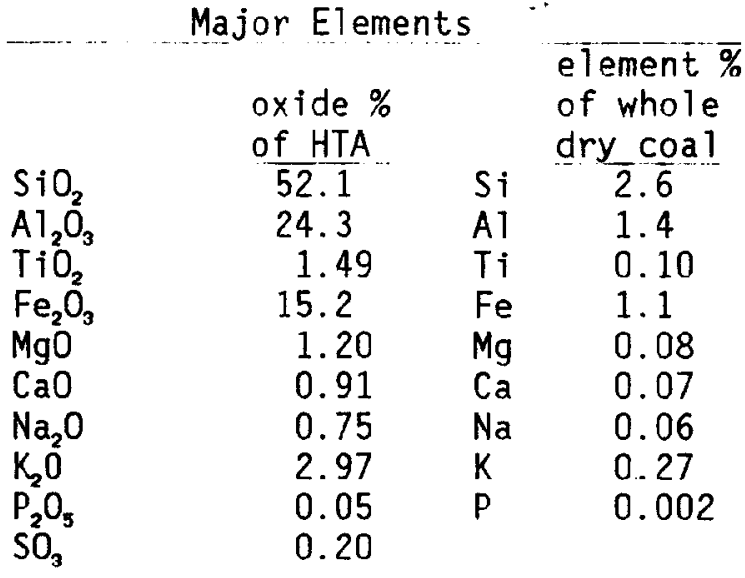

High-temperature ash (HTA) used for inorganic analysis $=10.75 \%$ of whole dry coal
Sample DECS-31

page 4 of 4

hvAb rank

sampled 6/21/95

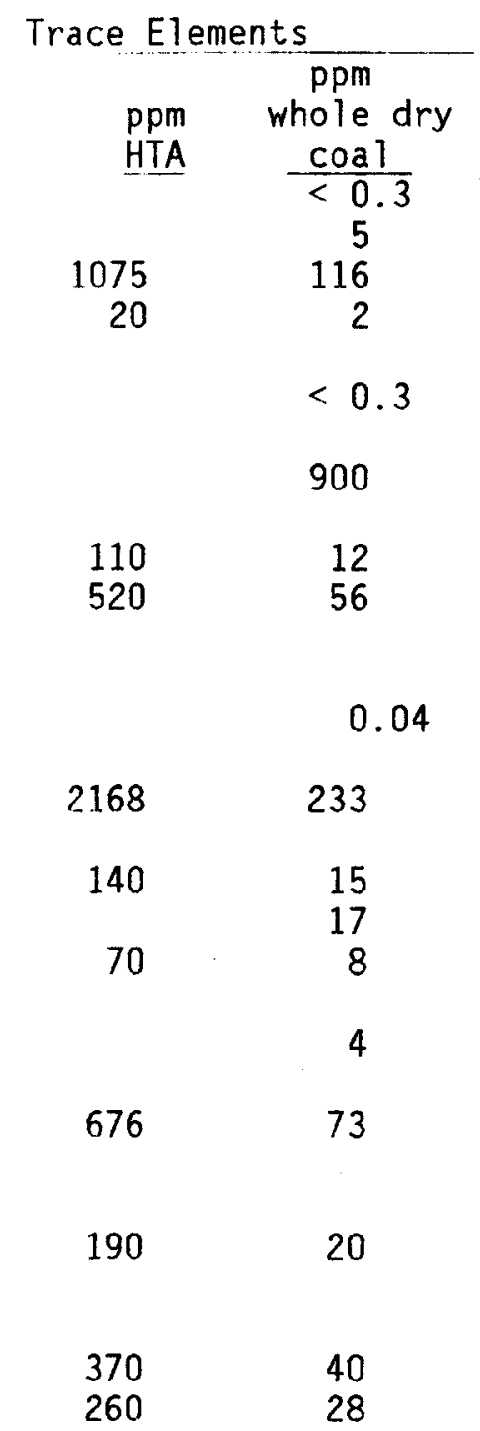

Trace Elements

ppm whole dry

HTA COal

$\mathrm{Ag}$

As

$\mathrm{Ba}$

$\mathrm{Be}$

$\mathrm{Bi}$

$\mathrm{Cd}$

Ce

C1

Co

$$
\mathrm{Cr}
$$

$$
\mathrm{Cu}
$$

$$
\text { Ga }
$$

$\mathrm{Hg}$

$\mathrm{Nb}$$$
\mathrm{Ni}
$$$$
\mathrm{Pb}
$$

$\mathrm{Rh}$

$$
\text { Se }
$$$$
\text { sn }
$$$$
\text { Sr }
$$$$
\text { Th }
$$

\begin{tabular}{|c|c|c|c|c|}
\hline & \multicolumn{2}{|c|}{$\begin{array}{l}\text { Reducing } \\
\text { a tmosphere }\end{array}$} & \multicolumn{2}{|c|}{$\begin{array}{l}\text { Oxidizing } \\
\text { atmosphere }\end{array}$} \\
\hline Intial deformation & $1343^{\circ} \mathrm{C}$ & $2450^{\circ} \mathrm{F}$ & $1463^{\circ} \mathrm{C}$ & $2665^{\circ} \mathrm{F}$ \\
\hline Softening & $1396^{\circ} \mathrm{C}$ & $2545^{\circ} \mathrm{F}$ & $1496^{\circ} \mathrm{C}$ & $2725^{\circ} \mathrm{F}$ \\
\hline Hemispherical & $1435^{\circ} \mathrm{C}$ & $2615^{\circ} \mathrm{F}$ & $1516^{\circ} \mathrm{C}$ & $2760^{\circ} \mathrm{F}$ \\
\hline Fluid & $1466^{\circ} \mathrm{C}$ & $2670^{\circ} \mathrm{F}$ & $1527^{\circ} \mathrm{C}$ & $2780^{\circ} \mathrm{F}$ \\
\hline
\end{tabular}

ro

Y

\section{ASH FUSION TEMPERATURES}


The Penn State Coal Sample Bank and Database

Sample DECS-32

page 1 of 4

Stockton - Lewiston Seam (Stockton Seam)

Kanawha County, WV

\section{SAMPLE LOCATION}

Kanawha County, West Virginia, USA

Cabin Creek Township near Mammoth, West Virginia

Eastern Coal Province

Appalachian Region

Mammoth (7.5') Topographic Quadrangle

Latitude $38^{\circ} 15^{\prime} 21^{\prime \prime}$ North, Longitude $81^{\circ} 18^{\prime} 13^{\prime \prime}$ West

\section{SAMPLE HISTORY}

Whole-Seam Channel Sample collected June 23, 1995 by Penn State

Mining method: underground

Coa1 Sample Bank reserve: $192 \mathrm{~kg}$ (424 1bs)

\section{SAMPLE INFORMATION}

Pennsylvanian

Pottsville Group

Kanawha Formation

Seam thickness at sample location: $183 \mathrm{~cm}(6 \mathrm{ft} 0$ in.)

Sample thickness:

Seam profile:

ROOF
$20 \mathrm{~cm}$
$5 \mathrm{~cm}$
$13 \mathrm{~cm}$
$104 \mathrm{~cm}$
$15 \mathrm{~cm}$
$25 \mathrm{~cm}$

gray shale

clarain, discontinuous shale

hard gray shale included

4" dul1 clarain, 1" vitrain

clarain, 1" shale included

dull clarain

bright clarain 
The Penn State Coal Sample Bank and Database

Stockton - Lewiston Seam (Stockton Seam)

Kanawha County, WV

Sample DECS-32

page 2 of 4

huAb rank

printed $12 / 07 / 95$

sampled $6 / 23 / 95$

PROXIMATE ANALYSIS

$\%$ Moisture

as $\frac{\mathrm{rec}^{\prime} \mathrm{d}}{2} \mathrm{dry}$

daf $\quad$ dmmf(Parr)

$\%$ Ash

19.76

20.30

$\%$ Vol. Matter

30.74

31.57

\% Fixed Carbon

46.86

48.12

$\begin{array}{ll}39.61 & 38.18 \\ 60.39 & 61.82\end{array}$

SULFUR FORMS

$\begin{array}{lll} & \text { dry } & \frac{\text { daf }}{0.13} \\ \text { \% Pyritic } & 0.10 & 0.01 \\ \text { \% Sulfate } & 0.01 & 0.78 \\ \% \text { Organic } & 0.62 & 0.92 \\ \text { \% Total } & 0.73 & \end{array}$

MOISTURE

$\%$ as received 2.64

$\%$ equilibrium 3.10

- ULTIMATE ANALYSIS

\begin{tabular}{|c|c|c|c|c|}
\hline$\%$ Ash & $\frac{\text { as rec'd }}{19.76}$ & $\frac{d r y}{20.30}$ & daf & $\frac{\operatorname{dmmf}(P a r r)}{(22.33 \% M M)}$ \\
\hline \% Carbon & 64.60 & 66.35 & 83.25 & 85.42 \\
\hline$\%$ Hydrogen & $4.38^{*}$ & 4.50 & 5.65 & 5.79 \\
\hline$\%$ Nitrogen & 1.07 & 1.10 & 1.38 & 1.42 \\
\hline \% Total Sulfur & 0.71 & 0.73 & 0.92 & \\
\hline$\%$ Oxygen (diff.) & $6.83^{*}$ & 7.02 & 8.81 & 7.37 \\
\hline
\end{tabular}

Dry \% Chlorine $=0.09$ Dry \% Carbon dioxide $=0.81$

\section{ELEMENTAL ANALYSIS}

\% Carbon

$\%$ Hydrogen

$\%$ Nitrogen

$\%$ Organic Sulfur

$\%$ Oxygen (diff.)

\% Mineral Matter

(incl. 0.19\% $\mathrm{FeS}_{2}$ ) dry

66.13

4.24

1.10

0.62

4.88

22.03
dmmf(Mod.P)

(22.03\% MM)

85.92

5.51

1.43

0.81

6.34

\section{CALORIFIC VALUE (Gross)}

MM-containing

MM-free (Parr)

MM-free (mod. Parr)

Net, dmmf Btu/lb

\begin{tabular}{ll}
\multicolumn{2}{c}{ dry } \\
\hline MJ/kg & $\frac{B t u / 1 b}{11853}$ \\
\hline 27.568 & 15213 \\
35.383 & 1523 \\
35.802 & 15393 \\
34.541 & 14851
\end{tabular}

as rec'd moist

$\mathrm{MJ} / \mathrm{kg} \quad \mathrm{Btu} / \mathrm{Tb}$

$26.840 \quad \overline{11540}$

$34.190 \quad 14700$

$34.583 \quad 14869$

\begin{tabular}{lr} 
equil. & moist \\
\hline MJ/kg & $\frac{B t u / 1 b}{11486}$ \\
\hline 26.715 & 14611 \\
33.983 & 1477 \\
34.371 & 14778
\end{tabular}

Mott-Spooner difference $=-19 \mathrm{Btu} / \mathrm{lb}$

\section{ATOMIC RATIOS (dmmf)}

Atomic $\mathrm{H} / \mathrm{C}$

Atomic $\mathrm{O} / \mathrm{C}$ $\frac{\text { Parr }}{0.815}$

0.065 mod. Parr

0.770

0.055 
The Penn State Coal Sample Bank and Database

Stockton - Lewiston Seam (Stockton Seam)

Kanawha County, WV

\section{RANK CALCULATIONS}

ASTM Rank (equilibrium moïst.) hvAb (as rec'd moist.) hvab

\section{Sample DECS-32}

page 3 of 4

printed $12 / 07 / 95$

sampled $6 / 23 / 95$
hvAb rank

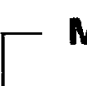

\section{MACERAL COMPOSITION (blue + white light, volume \%)}

Vitrinite

TOTAL VITRINITE

\begin{tabular}{|c|c|}
\hline $\begin{array}{l}\text { mineral- } \\
\text { free }\end{array}$ & $\begin{array}{l}\text { mineral- } \\
\text { containing }\end{array}$ \\
\hline 67.6 & $\begin{array}{r}59.4 \\
59.4\end{array}$ \\
\hline
\end{tabular}

Fusinite

Semifusinite

Macrinite

Micrinite

Sclerotinite

Inertodetrinite

TOTAL INERTINITE

$\begin{array}{rr}2.8 & 2.5 \\ 11.2 & 9.9 \\ 0.1 & 0.1 \\ 5.4 & 4.7 \\ 0.0 & 0.0 \\ 1.2 & 1.1\end{array}$

Sporinite

Resinite

Alginite

Cutinite

Liptodetrinite

Exudatinite

Bituminite

Fluorinite

TOTAL LIPTINITE

Mineral matter (Parr, volume \%)
$8.1 \quad 7.1$

$1.4 \quad 1.2$

$0.0 \quad 0.0$

$\begin{array}{ll}0.7 & 0.6\end{array}$

$1.5 \quad 1.3$

$0.0 \quad 0.0$

$0.0 \quad 0.0$

$0.0 \quad 0.0$

$11.7 \quad 10.2$
12.17

\section{REFLECTANCE DATA}

Vitrinite: Mean-max $R_{0}: 0.90 \%$

$\begin{array}{llllll}\text { Vtypes: } & \frac{V 6}{1.0} & \frac{V 7}{8.0} & \frac{V}{36} 8 & \frac{V}{53} .0 & \frac{V 10}{2.0}\end{array}$

\section{CAKING AND MECHANICAL PROPERTIES}

Free-swelling index

Hardgrove grindability index

Vickers' microhardness index Washability data not available
5

47.4

n.d.

\section{4}

4


The Penn State Coal Sample Bank and Database

Stockton - Lewiston Seam (Stockton Seam)

Kanawha County, WV

hvAb rank

INORGANIC ELEMENT ANALYSIS

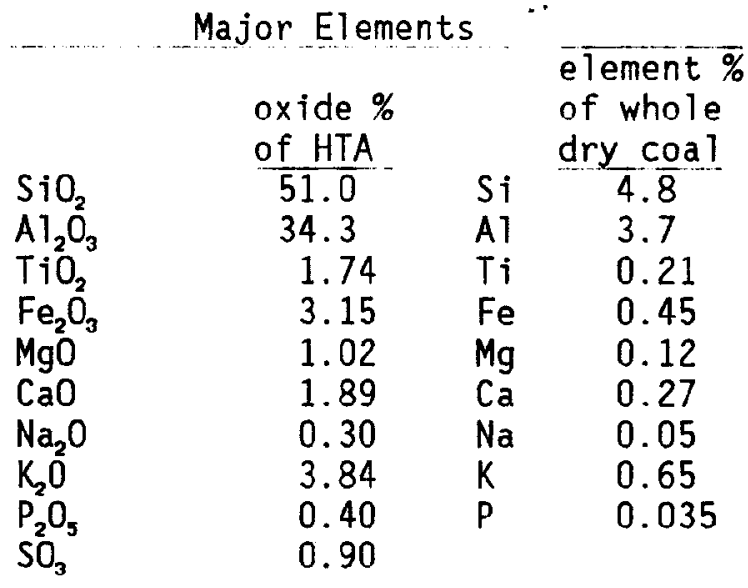

High-temperature ash (HTA)

used for inorganic analysis

$=20.23 \%$ of whole dry coal
Sample DECS-32

page 4 of 4

printed $12 / 07 / 95$

sampled $6 / 23 / 95$

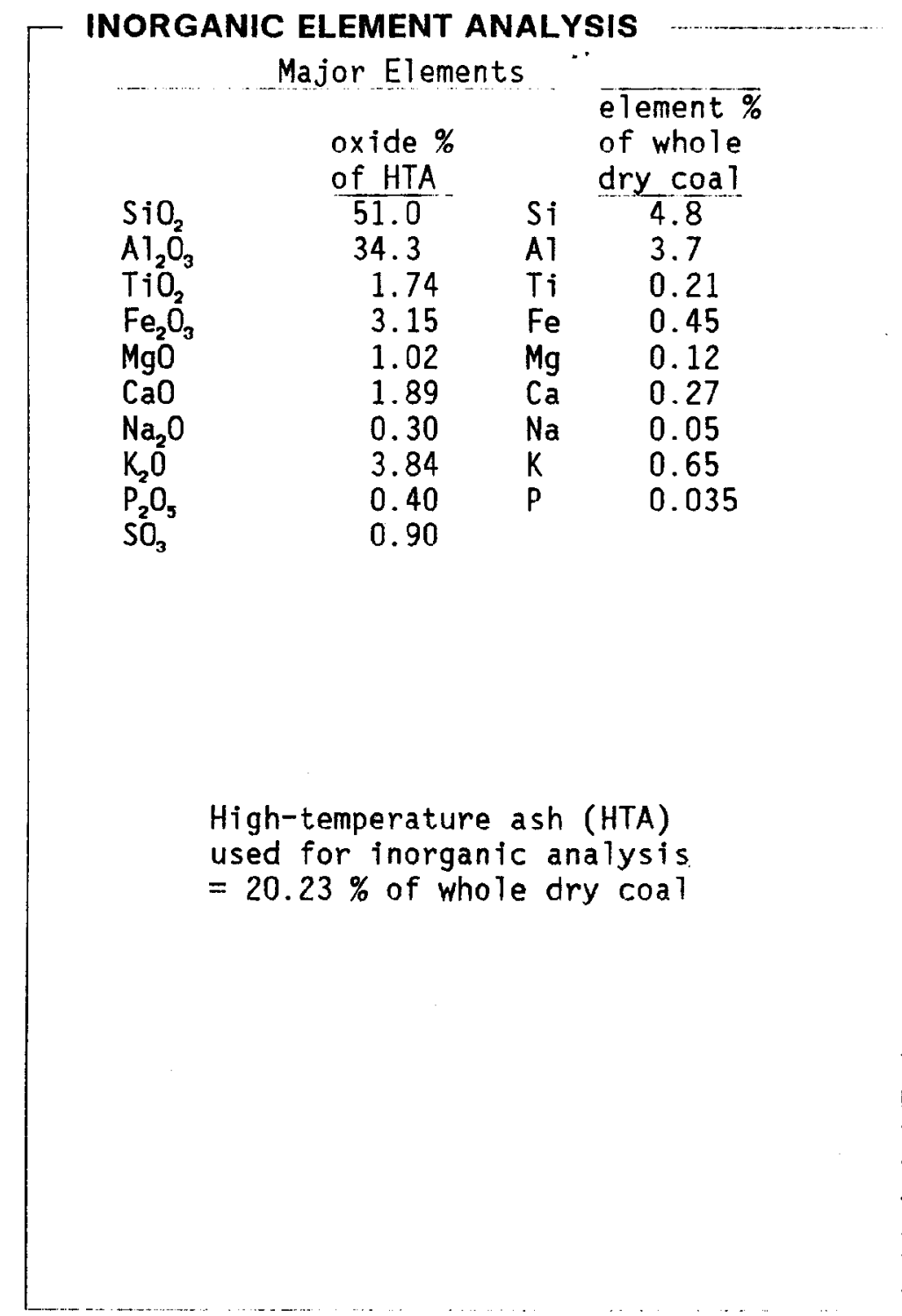

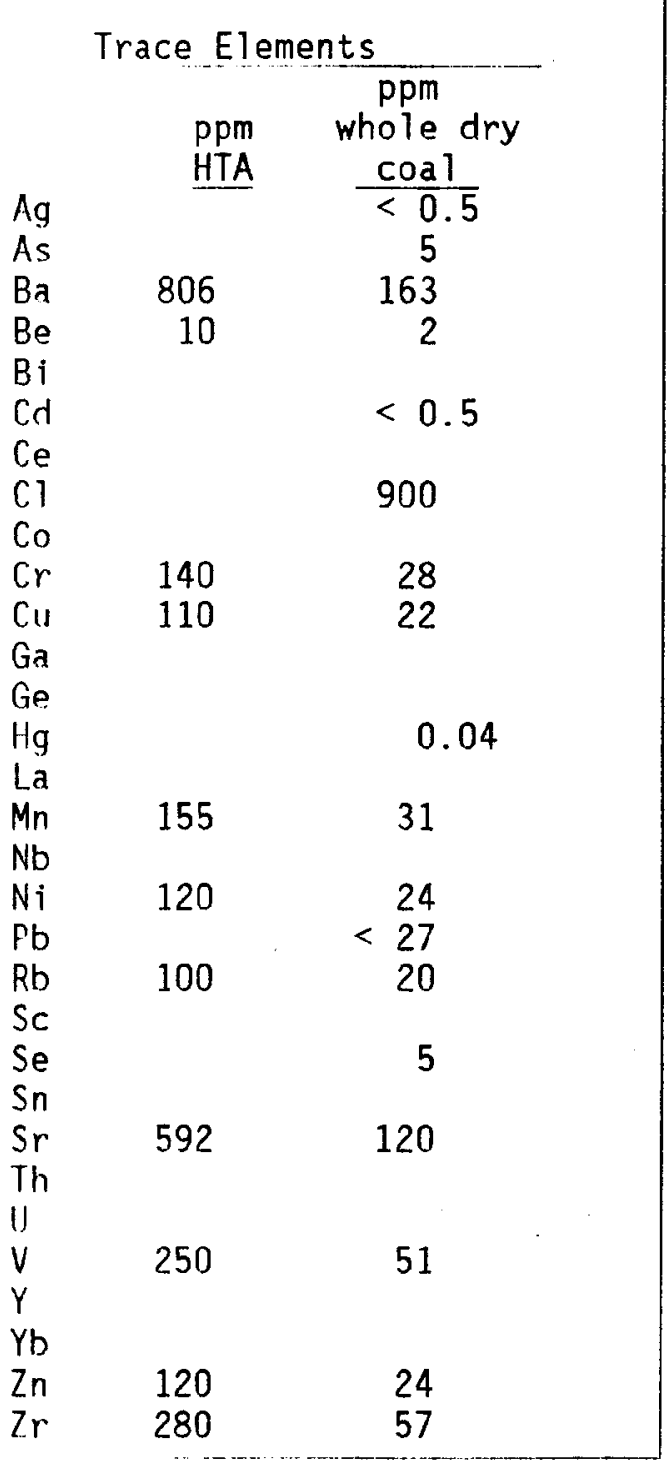

ASH FUSION TEMPERATURES

Initial deformation

Softening

Hemispherical

Fluid

\begin{tabular}{|c|c|}
\hline $\begin{array}{r}\operatorname{Rec} \\
\text { atmo }\end{array}$ & $\begin{array}{l}\text { cing } \\
\text { phere }\end{array}$ \\
\hline $\begin{array}{l}1538^{\circ} \mathrm{C}+ \\
1538^{\circ} \mathrm{C}+ \\
1538^{\circ} \mathrm{C}+ \\
1538^{\circ} \mathrm{C}+\end{array}$ & $\begin{array}{l}2800^{\circ} \mathrm{Ft} \\
2800^{\circ} \mathrm{Ft} \\
2800^{\circ} \mathrm{Ft} \\
2800^{\circ} \mathrm{Ft}\end{array}$ \\
\hline
\end{tabular}

Oxidizing

atmosphere

$1538^{\circ} \mathrm{C}+2800^{\circ} \mathrm{F}+$

$1538^{\circ} \mathrm{C}+2800^{\circ} \mathrm{F}+$

$1538^{\circ} \mathrm{C}+2800^{\circ} \mathrm{F}+$

$1538^{\circ} \mathrm{C}+2800^{\circ} \mathrm{F}+$ 
The Penn State Coal Sample Bank and Database

Sample DECS-33

Ohlo \#4A Seam (Clarion Seam)

hvBh rank

page 1 of 4

Meigs County, OH

printed $12 / 07 / 95$

sampled $7 / 25 / 95$

\section{SAMPLE LOCATION}

Meigs County, Ohio, USA

Columbia Township near Wilkesville, Ohio

Eastern Coal Province

Appalachian Region

Vales Mills (7.5') Topographic Quadrangle

Latitude and Longitude not recorded

\section{SAMPLE HISTORY}

Whole-Seam Channel Sample collected July 25, 1995 by Penn State

Mining method: underground

Coal Sample Bank reserve: $173 \mathrm{~kg}$ (383 1bs)

\section{SAMPLE INFORMATION}

Pennsylvanian

Al legheny Group

Seam thickness at sample location: $142 \mathrm{~cm}$ (4 ft 8 in.)

Sample thickness:

Seam profile:

$\begin{aligned} \text { ROOF } & \text { gray mudstone } \\ 58 \mathrm{~cm} & \text { clarain } \\ 8 \mathrm{~cm} & \text { soft gray mudstone NOT SAMPLED } \\ 33 \mathrm{~cm} & \text { dull clarain } \\ 5 \mathrm{~cm} & \text { hard tan siltstone NOT SAMPLED } \\ 38 \mathrm{~cm} & \text { clarain, occ. pyrite lenses } \\ \text { FLOOR } & \text { gray shale }\end{aligned}$


The Penn State Coal Sample Bank and Database

Ohio \#4A Seam (Clarion Seam)

huBb rank

Sample DECS-33

page 2 of 4

Meigs County, OH

printed $12 / 07 / 95$

sampled $7 / 25 / 95$

PROXIMATE ANALYSIS

\% Moisture

\begin{tabular}{cc} 
as rec'd & dry \\
\hline 5.97 & \\
11.30 & 12.02 \\
40.49 & 43.06 \\
42.24 & 44.92
\end{tabular}

daf dmmf(Parr)

$\%$ Ash

$\%$ Vol. Matter

\% Fixed Carbon

42.24

44.92

SULFUR FORMS

$\%$ Pyritic
$\%$ Sulfate
$\%$ Organic
$\%$ Total

$\begin{array}{ll}\frac{\text { dry }}{1.41} & \frac{\text { daf }}{1.60} \\ 0.01 & 0.01 \\ 2.32 & 2.64 \\ 3.74 & 4.25\end{array}$

MOISTURE

$\%$ as received

5.97

$\%$ equilibrium

5.90

$48.94 \quad 47.79$

$51.06 \quad 52.21$

ULTIMATE ANALYSIS

$\%$ Ash

\% Carbon

$\%$ Hydrogen

$\%$ Nitrogen

\% Total Sulfur

$\%$ Oxygen (diff.)

3.74

4.25

Dry \% Chlorine $=0.14$ Dry \% Carbon dioxide $=0.70$

\section{ELEMENTAL ANALYSIS}

\% Carbon

$\%$ Hydrogen

\% Nitrogen

$\%$ Organic Sulfur

$\%$ Oxygen (diff.)

\% Mineral Matter

(inc1. 2.64\% $\mathrm{FeS}_{2}$ )

$$
\frac{\text { as } \mathrm{rec}^{\prime} \mathrm{d}}{11.30} \quad \frac{\mathrm{dry}}{12.02} \quad \mathrm{daf} \quad \frac{\mathrm{dmmf}(\text { Parr })}{(15.04 \% M M)}
$$

\section{daf $\frac{\text { dmmf(Parr) }}{(15.04 \% M M)}$}

65.36

$4.80^{*}$

69.51

5.11

1.19

3.74

8.43

3.52

$7.93 *$

* excluding
79.01

81.81

5.81

6.01

1.35

1.40

10.77

9.58 ture$$
\text { D.14 Dry }
$$

\section{CALORIFIC VALUE (Gross)}

MM-containing

MM-free (Parr)

MM-free (mod. Parr)

Net, dmmf Btu/lb

\begin{tabular}{lr}
\multicolumn{2}{c}{ dry } \\
\hline MJ/kg & Btu/1b \\
\hline 29.345 & 12617 \\
34.027 & 14630 \\
34.041 & 14636 \\
32.755 & 14083
\end{tabular}

69.32

4.98

1.19

2.32

7.87

14.32 $\frac{\operatorname{dmm} f(\operatorname{Mod} . P)}{(14.32 \% \operatorname{MM})}$

80.90

5.81

1.39

2.71

9. 19

Mott-Spooner difference $=-138 \mathrm{Btu} / 1 \mathrm{~b}$

as rec'd moist

$\overline{\mathrm{MJ}} / \mathrm{kg} \quad \mathrm{Btu} / \mathrm{Tb}$

$27.594 \quad 11864$

$31.662 \quad 13613$

$31.692 \quad 13626$

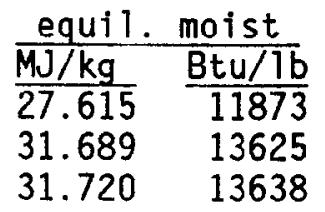

ATOMIC RATIOS (dmmf)

Atomic $\mathrm{H} / \mathrm{C}$

\begin{tabular}{ll} 
Parr & mod. Parr \\
\hline 0.883 & 0.863 \\
0.099 & 0.085
\end{tabular}

Atomic $0 / C$

0.099

0.085 
The Penn State Coal Sample Bank and Database

Ohio \#4A Seam (Clarion Seam)

hvBb rank

Sample DECS-33

page 3 of 4

Meigs County, OH

\section{RANK CALCULATIONS}

ASTM Rank (equilibrium moist.) hvBb Reflectance Rank hvCb

$$
\text { (as rec'd moist.) hvBb }
$$

\section{MACERAL COMPOSITION (blue + white light, volume \%)}

Vitrinite

TOTAL VITRINITE

Fusinite

Semifusinite

Macrinite

Micrinite

Sclerotinite

Inertodetrinite

TOTAL INERTINITE

Sporinite

Resinite

Alginite

Cutinite

Liptodetrinite

Exudatinite

Bituminite

Fluorinite

TOTAL LIPTINITE

$$
\begin{aligned}
& \text { mineral- } \\
& \text { free } \\
& \overline{75} . \overline{7}
\end{aligned}
$$

76.7

mineral-

containing

70.7

70.7

3.4

4.7

0.1

6.1

0.0

0.7

15.0

4.5

1.2

0.0

0.5

1.7

0.2

0.1

0.1

8.3
3.1

4. 4

0.1

5.6

0.0

0.6

13.8

4.1

1.1

0.0

0.5

1.6

0.2

0.1

0.1

7.7

Mineral matter (Parr, volume \%)

7.86

\section{REFLECTANCE DATA}

Vitrinite: Mean-max $R_{0}: 0.51 \%$

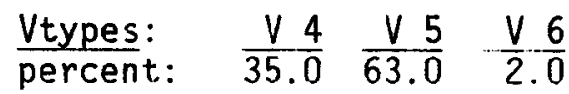

\section{CAKING AND MECHANICAL PROPERTIES}

Free-swelling index

Hardgrove grindability index

Vickers' microhardness index

Washability data not available

\section{4}

48.6

n.d.
Gieseler Coal Plastometer:

Initial softening $379^{\circ} \mathrm{C}$

Maximum fluidity $\quad 423^{\circ} \mathrm{C}$

Solidification

Fluid temp. range

$454^{\circ} \mathrm{C}$

Maximum fluidity $75^{\circ} \mathrm{C}$

$86 \mathrm{ddpm}$ 
The Penn State Coal Sample Bank and Database

Ohio \#4A Seam (Clarion Seam)

Meigs County, OH

INORGANIC ELEMENT ANALYSIS

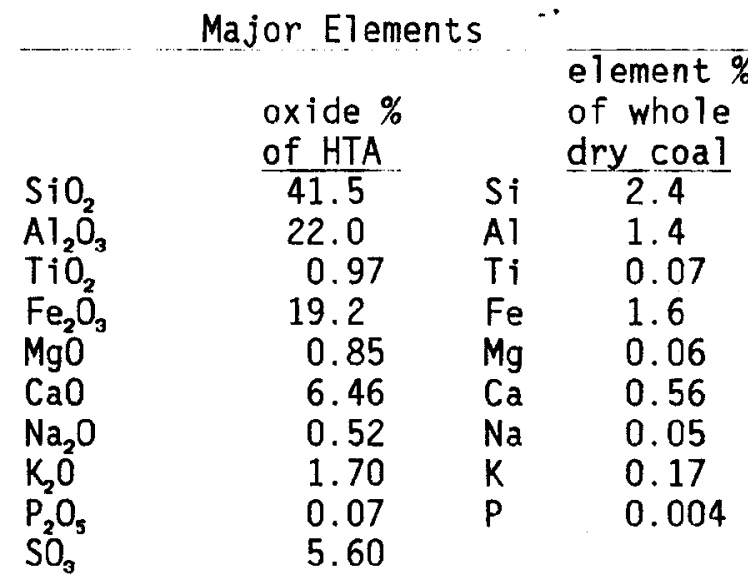

High-temperature ash (HTA) used for inorganic analysis

$=12.23 \%$ of whole dry coal
hvBb rank

Sample DECS-33

page 4 of 4

printed $12 / 07 / 95$

sampled $7 / 25 / 95$

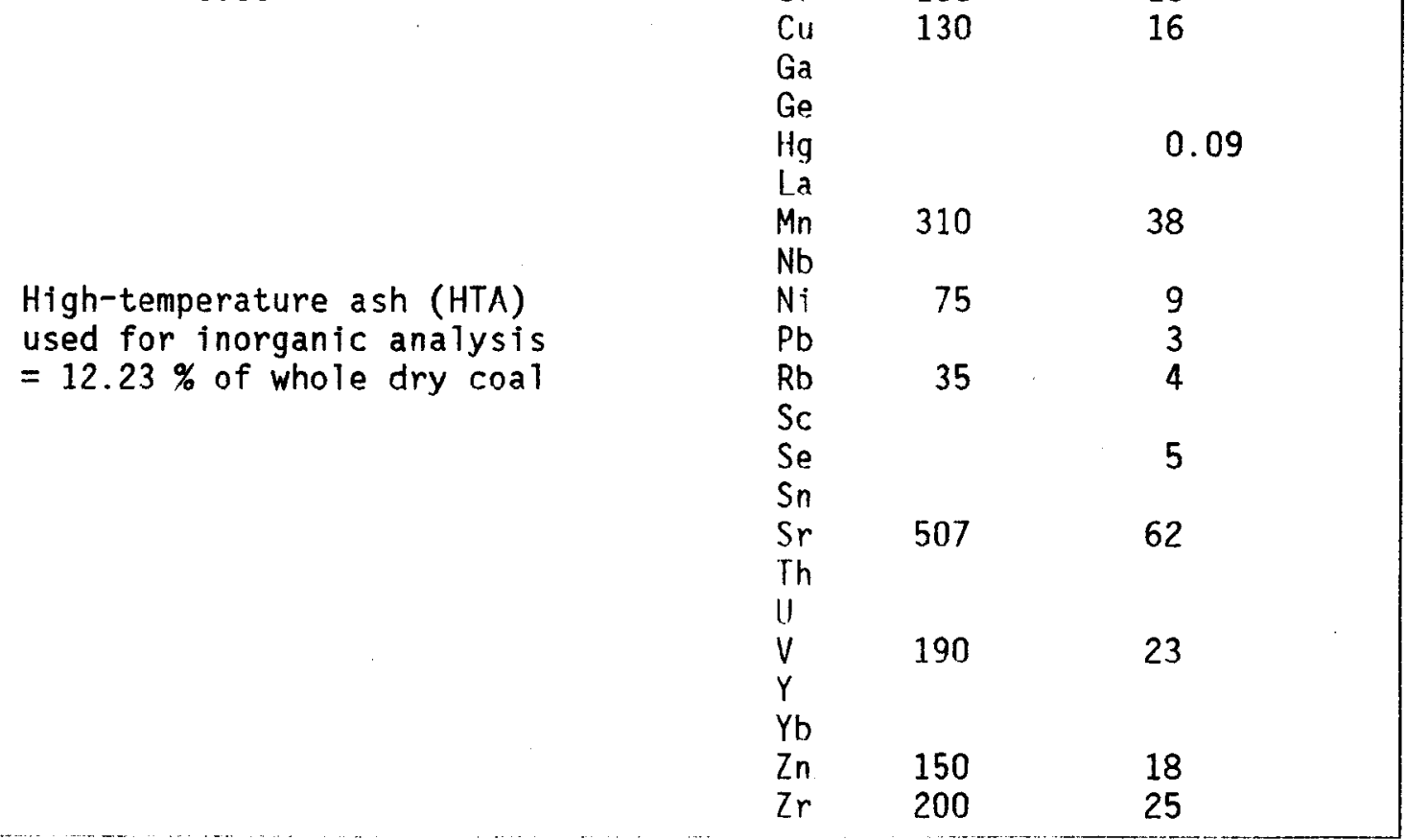

\section{ASH FUSION TEMPERATURES}

\begin{tabular}{|c|c|c|}
\hline & $\begin{array}{r}\mathrm{Re} \\
\mathrm{atm} \\
\end{array}$ & $\begin{array}{l}\text { cing } \\
\text { phere }\end{array}$ \\
\hline $\begin{array}{l}\text { Initial deformation } \\
\text { Softening } \\
\text { Hemispherical } \\
\text { Fluid }\end{array}$ & $\begin{array}{l}1204^{\circ} \mathrm{C} \\
1235^{\circ} \mathrm{C} \\
1277^{\circ} \mathrm{C} \\
1316^{\circ} \mathrm{C}\end{array}$ & $\begin{array}{l}2200^{\circ} \mathrm{F} \\
2255^{\circ} \mathrm{F} \\
2330^{\circ} \mathrm{F} \\
2400^{\circ} \mathrm{F}\end{array}$ \\
\hline
\end{tabular}

Trace Elements

$\mathrm{ppm}$

ppm whole dry

HTA

$\frac{\text { coal }}{<} \frac{0.3}{4}$

358

15

4

44

2

$<0.3$

1400

16

130

.

CI

Co

$\mathrm{Cr}$

$\mathrm{Cu}$

$\mathrm{Ga}$

Ge

Hg

$$
\mathrm{Mn}
$$

$\mathrm{Bi}$ 
APPENDIX E. Coal Sample Bank and Database Brochure

\section{THE DEPARTMENT}

\author{
OF ENERGY
}

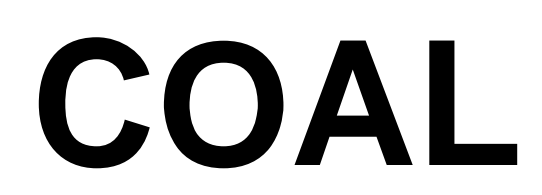

\section{SAMPLE BANK}

AND

\section{DATABASE}

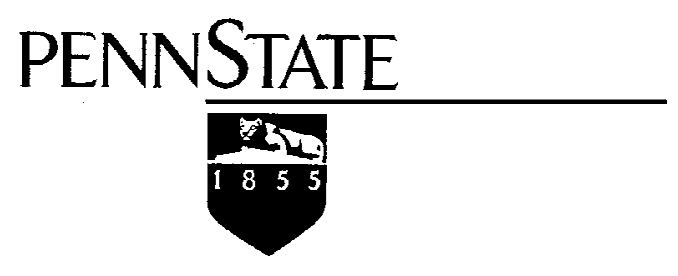

March, 1999
Penn State is maintaining a suite of 56 coals and a corresponding computerized database of analyses for use by DOE contractors and grantees. This includes the 33 well-preserved DECS samples, collected in an ongoing effort begun in 1989, and 23 older PSOC samples. The coals represent a wide spectrum of the major coalfields of the United States and were selected in order to achieve a useful distribution of important coals by rank, geologic province, maceral composition, sulfur content and forms, and ash yield and composition. Due consideration was also given to the prior use of these coals by researchers and to their economic importance. The coals in the DOE Coal Sample Bank are listed at the right. Most were collected as full-seam channel samples (Chan-Seam); however, drill cutting (Drll-Seam), working section of seam (Chan-Work), bench (Chan-Bnch), lithotype (ChanLith) and run-of-mine (ROM) samples were also acquired.

\section{Sample Collection and Processing}

DECS series samples are the newest and best preserved samples in the collection, and should be chosen when possible for research requiring moderate quantities of sample. They were collected in $180 \mathrm{~kg}(400 \mathrm{lb}$.) quantities from recently exposed areas of active mines, where they were placed in $113 \mathrm{~L}$ (30 gal.) steel drums with high-density gaskets and purged with argon. As soon as feasible after collection, processing was performed in order to obtain representative subsamples. These were sealed under argon in foil multilaminate bags, which have been shown by annual monitoring to preserve samples very well, and are kept in refrigerated storage $\left(3^{\circ} \mathrm{C}\right)$.

DECS samples are available in packages of three nominal sizes:

$70 \mathrm{~g}(3 \mathrm{oz}$.) at minus $0.20 \mathrm{~mm}$ ( $-60 \mathrm{mesh})$

$300 \mathrm{~g}(2 / 3 \mathrm{lb})$ at minus $0.85 \mathrm{~mm}(-20 \mathrm{mesh})$

$2.3 \mathrm{~kg}(5 \mathrm{lb})$ at minus $6 \mathrm{~mm}(-1 / 4 \mathrm{inch})$.

The $300 \mathrm{~g}$ containers are the ones most often requested by research agencies. Some nonrepresentative blocks of coal, sealed in argon and refrigerated, are also available for certain coals in the Sample Bank.

Older PSOC samples were collected similarly, but $300 \mathrm{~g}$ samples were sealed under argon in polyethylene bags which were then sealed in steel cans. Larger quantities were stored in polyethylene buckets or drums. 
The Department of Energy Coal Sample Bank

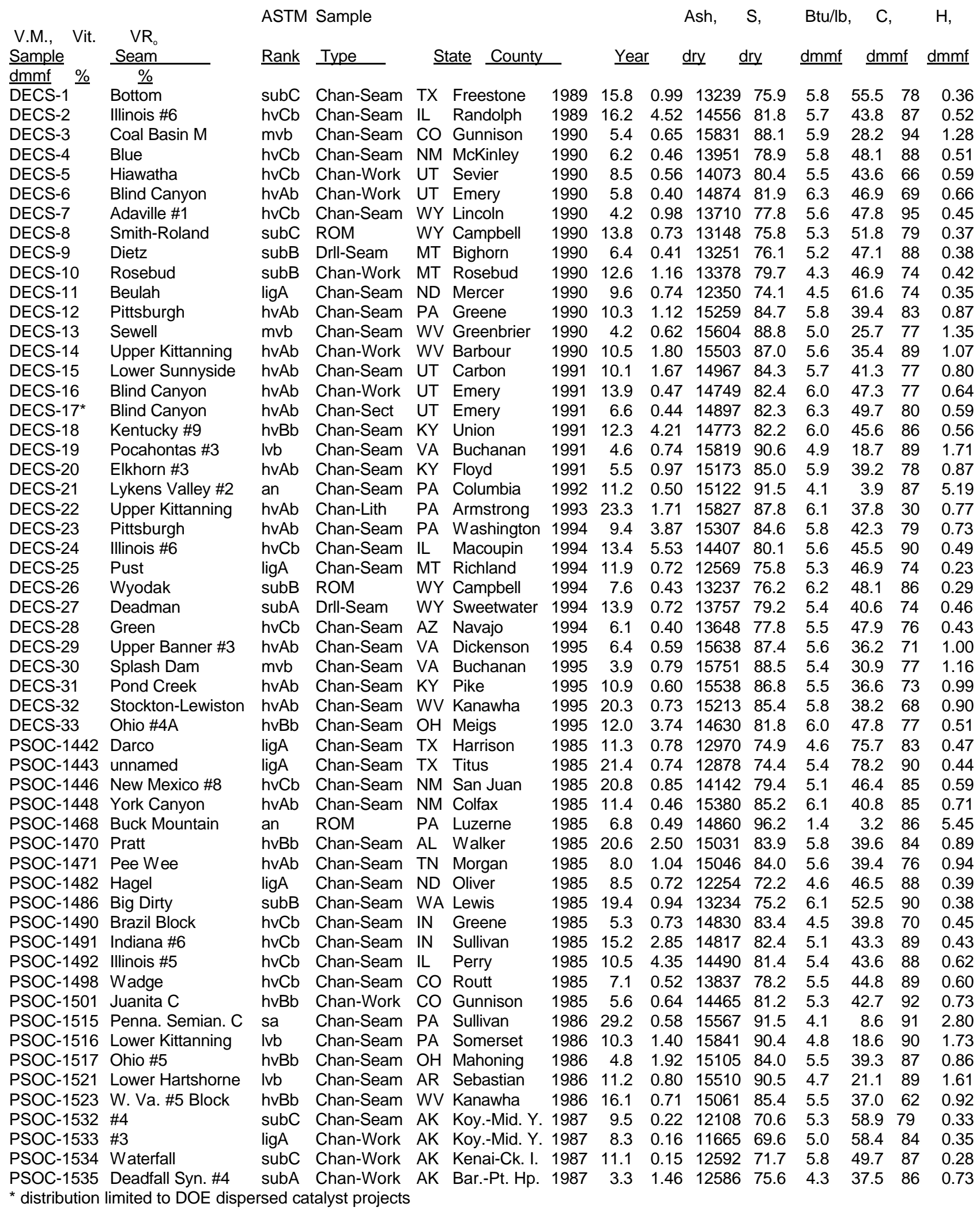




\section{Analysis}

Each of the DOE Sample Bank coals has been subjected to the following analytical procedures: proximate analysis, ultimate analysis, sulfur forms, calorific value, maceral analysis, vitrinite reflectance $\left(\mathrm{VR}_{\mathrm{o}}\right)$, ash fusion determination, free swelling index, Hardgrove grindability, major inorganic and trace elements, equilibrium moisture, and $\mathrm{CO}_{2}$. Gieseler plastometry and a standardized liquefaction test were performed on appropriate samples. NMR and $\mathrm{py} / \mathrm{gc} / \mathrm{ms}$ results were obtained on selected samples.

\section{Sample Availability}

Coal samples from the DOE Sample Bank are available to members of the coal research community. Assistance can be given in identifying samples that match specifications or that best suit the research needs of the requestor.

\section{DOE contractors and grantees may receive, at no cost, up to: \\ $1 \mathrm{~kg}$ of $-0.85 \mathrm{~mm}$ (-20 mesh) coal or \\ $300 \mathrm{~g}$ of $-0.25 \mathrm{~mm}$ (-60 mesh) coal}

Beyond this limit and for larger quantities or special preparation of samples, provision will be at cost to the requestor for preparation, mailing and handling. All requests for more than $2.3 \mathrm{~kg}$ (5 lbs.) of a single DECS sample or $4.5 \mathrm{~kg}$ (10 lbs.) of a single PSOC sample must be approved by the DOE Project Manager. DECS-17 is limited to $1630 \mathrm{~g}$ bags ( $1 \mathrm{lb}$.) per year, for DOE dispersed catalyst liquefaction research only.

Penn State currently maintains a Sample Bank that contains over 1000 samples in addition to the DOE Sample Bank of 56 coals. If a DOE contractor's or grantee's needs cannot be met from the 56 coals, then suitable samples can be provided from the larger bank; there is a charge for this service. A booklet describing the entire Penn State Coal Sample Bank and Database is available from the Coal and Organic Petrology Laboratories.

\section{Coal Database, Printouts and Searches}

The data that have been assembled by Penn State on the DOE Sample Bank coals have been computerized and are available on request to $\mathrm{DOE}$ contractors and grantees. In addition to the analytical data described above, the DOE Coal Database includes details on sample history, location, geology, and seam strata information.
Full (four to five page) or condensed (one-page) printouts of data in $81 / 2$ by 11" format can be provided for any sample. The one-page printout is useful for most purposes and contains sample location, geologic information, proximate analysis, equilibrium moisture, calorific value, sulfur forms, ultimate analysis, maceral composition, reflectance data, rank parameters, technologic properties, and physical properties. The full printout includes these data in more detail and calculated to various bases of expression, as well as major inorganic and trace element analyses, ash fusion temperatures, and $\mathrm{CO}_{2}$. Liquefaction, $\mathrm{NMR}$, and $\mathrm{py} / \mathrm{gc} / \mathrm{ms}$ results are also available separately for most DECS samples. Data printouts for DOE Sample Bank samples will be provided at no cost to DOE contractors and grantees.

A staff of professionals at Penn State can undertake Database searches to identify samples meeting specified criteria. Simple searches resulting in tables of data or a set of printouts are done at no cost for DOE contractors and grantees. More extensive searches, statistics or electronic transmission of data sets can be performed; a charge may be made for this service.

Investigators can perform their own simple searches on our web site (see below). It includes limited data for all DECS samples and a selected subset of other Penn State samples.

\section{Ordering and Assistance}

Request forms, a booklet describing the entire Penn State Coal Sample Bank and Database, and assistance in acquiring samples and data can be obtained from:

Coal and Organic Petrology Laboratories

The Pennsylvania State University

105 Academic Projects Building

University Park, PA 16802-2300

(814) 865-6543 Fax: (814) 863-7432

http://www.ems.psu.edu/COPL

Approval for the provision of larger numbers or quantities of samples must be requested from the Department of Energy Project Manager. 